sui generis
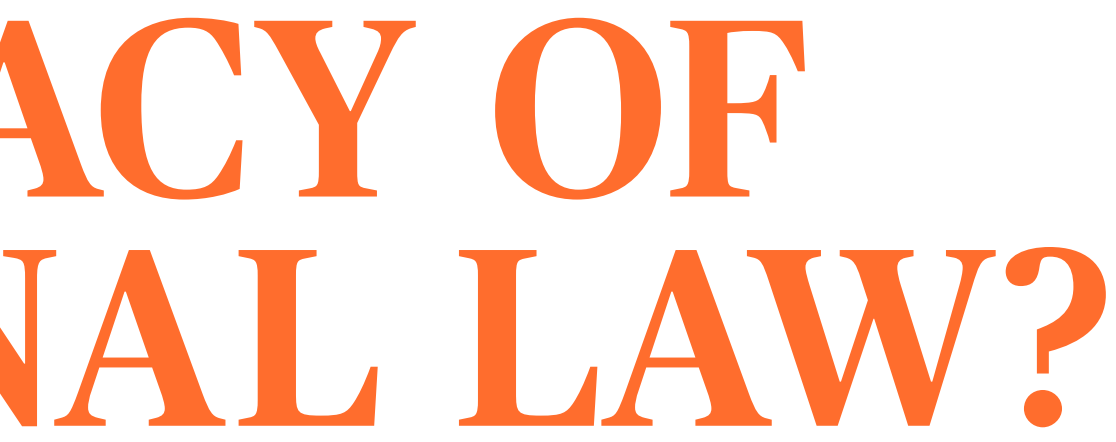

Indeterminacy of International Law?

Severin Meier 

Severin Meier

\section{Indeterminacy of International Law?}


About the digital version of this book:

- The digital version (open access) is available on the publisher's website (www.suigenerisverlag.ch), on Google Books, and directly via the Digital Object Identifier (DOI). The DOI for the present book is provided in the imprint.

- All legal provisions as well as all freely accessible decisions from courts and public authorities are linked in the digital version.

- The authors often use links to other sources in their manuscripts. These are not printed in the books but are included as hyperlinks in the digital version.

- Hyperlinks are provided using permalinks. These are links to the archived version of the web pages at the time of linking. The links are persistent, i.e. they still work even if the original page is no longer accessible and their content does not change if the original page changes. 
Severin Meier

\section{Indeterminacy of International Law?}





\section{Acknowledgements}

For his excellent supervision and generous support, I wish to thank Oliver Diggelmann. As early as within the first few weeks, he managed to channel my interests into a feasible research project. Throughout my doctoral work, he struck the perfect balance between allowing me the necessary intellectual freedom and-at the right time-steering my research away from difficulties and into more promising avenues. This freedom enabled me to stay motivated and committed to explore what I deem one of the most pressing issues of the discipline, while resting assured that the project did not slide down one of the many slippery slopes that surround it. I am also grateful to Bardo Fassbender for having agreed to act as second assessor, and for his valuable input at an early stage. During my employment as a research assistant to Helen Keller, I gained important insights into the reasoning and decision-making processes of international judges, for which I would like to thank her. Moreover, I am grateful to the sui generis team for their excellent work and to the Swiss National Science Foundation for their generous financial support.

I am much obliged for the input of my teachers and friends from Geneva, Leiden, Oxford, Zurich, and Helsinki, as well as to scholars around the world who have generously provided feedback. In particular, I wish to express my gratitude to Dapo Akande, Philip Allott, Odile Ammann, Andrea Bianchi, Damian Cueni, Mónica Garcia-Salmones Rovira, Alexandra Hansen, Jörg Kammerhofer, Jan Klabbers, Philippe Kuhn, Brian Leiter, Parvathi Menon, Daniel Moeckli, Johannes Reich, Ukri Soirila, Lawrence Solum, Ingo Venzke, Jochen von Bernstorff, Michael Waibel, Reto Walther, and Josef Weinzierl. Moreover, I would like to especially acknowledge the contribution of my friend Sandra Ujpétery, whose comments on form and substance have left their mark on every page of this thesis.

I would not have written about the indeterminacy of international law if discovering Martti Koskenniemi's publications had not profoundly shaken my views on the discipline at the beginning of my graduate studies. I have been convinced ever since that most questions posed in international law can only be seriously answered once David Kennedy and Martti Koskenniemi's structural indeterminacy thesis has been addressed adequately and in detail. Dedicated to precisely this task, the present research project started out as a defence of the structural indeterminacy thesis before evolving into a critique thereof. I am grateful to the Faculty of Law of the University of Zurich for 
having provided the funds for me to do research at the Erik Castrén Institute in Helsinki. During my stay in Finland, it was an honour and an intellectual delight to receive Martti Koskenniemi's constructive critique of my main arguments.

Without the wholehearted support from my family on all levels, I would not have had the privilege to dedicate several years of my life to exploring the fields of knowledge I consider most fascinating. I thank my parents, Werner and Yvonne-Denise, for their genuine interest in my research and for providing insights from their areas of expertise. Finally, my deepest thanks go to my wife, Melis. At the beginning of my research project, when I still believed in the structural indeterminacy thesis, I repeatedly tried to convince her of the pervasive instability of (international) law. To my frustration, however, shea practising lawyer-kept insisting on the certainties of law. In so doing, she contributed to making me understand what came to be the main argument of the present thesis: that legal (in)determinacy does not depend on theories that are independent of practice but merely on legal practice itself.

For these reasons and many more, I thank you, Melis, Werner, and YvonneDenise. This thesis is dedicated to you.

Zurich, 14 March 2020

Severin Meier 


\section{Contents}

Acknowledgements …

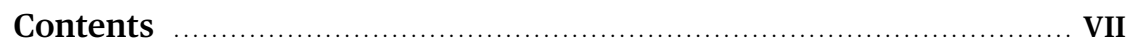

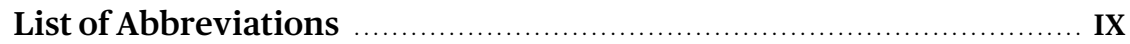

I. Turtles All the Way Down …................................................. 1

I.A The Research Question and Its Relevance ........................... 1

I.B Terminology and Methodological Challenges .................. 8

I.B.1 The Terms 'Determinacy' and 'Indeterminacy' .......... 9

I.B.2 Different Forms of (In)determinacy …................. 11

I.B.3 Predictability and Determinacy ……........................ 13

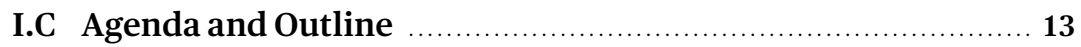

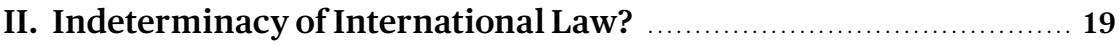

II.A Types of Legal (In)determinacy Theses …...................... 19

II.A.1 At One End of the Spectrum:

The Imaginary Global Determinacy Thesis ............. 19

II.A.2 Linguistic Indeterminacy …….............................. 27

II.A.3 Indeterminacy Arising from the

Composition of Norms …........................................ 36

II.A.3.i Indeterminacy Arising from

Legal Interpretation ................................... 37

II.A.3.ii Indeterminacy Arising from

Fact-Ascertainment …................................ 45

II.A.4 At the Other End of the Spectrum: Indeterminacy

of the Structure of International Law ....................... 51

II.A.4.i International Law as an Argumentative Practice $\mathbf{5 1}$

II.A.4.ii The Structural Indeterminacy of

International Law: David Kennedy ....................54

II.A.4.iii The Contradictory Liberal Roots of

International Law: Martti Koskenniemi ….........62 62

II.A.4.iv A 'Crit' Ahead of Time: Hans Kelsen .................. 66 
II.B Critical Analysis of (In)determinacy Theses …................ 71

II.B.1 The Creation of Legal Meanings ……................... 71

II.B.1.i Linguistic Indeterminacy:

The Contextual Meaning of Texts ….................. 72

II.B.1.ii Interpretive Communities and the Attribution of Meanings to Objects of Interpretation …....... 83

II.B.1.ii.a. Legal Interpretation …….............. 89

II.B.1.ii.b. Fact-Ascertainment ….................. 94

II.B.1.iii Interim Conclusion .................................... 97

II.B.2 The Limits of the Structural Indeterminacy Thesis ... 100

II.B.2.i The Existence of 'Easy Cases' ........................ 104

II.B.2.ii The Practice of Legal Theory ......................... 107

II.B.2.iii A Middle Way between Factual Acceptance and Objective Truth? ................................. 113

II.B.3 A New Framing of (In)determinacy Theses ............ 116

II.B.3.i The Impossible Dualism between Norms and Their Interpretation …............................ 118

II.B.3.i.a. There Is No Background Scheme in Law and Language ........................ 119

II.B.3.i.b. Breaking out of the Infinite Regress of Rules

II.B.3.ii Normativity Arising from the Practice of International Law

II.B.3.iii How Questions about the Extent of Legal Determinacy Should Be Framed

II.B.3.iv How Does a Legal Outcome Come to Be Accepted?

II.B.3.v The Extent of Determinacy in Domestic and International Law

III. Conclusion

III.A Summary of Findings 155

III.B Can Research on Structural Biases Succeed? 162

III.C Turtles and the Stories of International Lawyers 165 


\section{List of Abbreviations}

$\begin{array}{ll}\text { ACHPR } & \text { African Charter on Human and Peoples' Rights } \\ \text { ACHR } & \text { African Convention on Human Rights } \\ \text { CLS } & \text { Critical Legal Studies } \\ \text { ECHR } & \text { European Convention on Human Rights } \\ \text { EComHR } & \text { European Commission of Human Rights } \\ \text { ECtHR } & \text { European Court of Human Rights } \\ \text { ICCPR } & \text { International Covenant on Civil and Political Rights } \\ \text { ICJ } & \text { International Court of Justice } \\ \text { ICRC } & \text { International Committee of the Red Cross } \\ \text { ILC } & \text { International Law Commission } \\ \text { PCA } & \text { Permanent Court of Arbitration } \\ \text { PCIJ } & \text { Permanent Court of International Justice } \\ \text { UN } & \text { United Nations } \\ \text { UNCLOS } & \text { United Nations Convention on the Law of the Sea } \\ \text { UNHCR } & \text { United Nations High Commissioner for Refugees } \\ \text { UNTS } & \text { United Nations Treaty Series } \\ \text { VCLT } & \text { Vienna Convention on the Law of Treaties } \\ \text { WTO } & \text { World Trade Organisation }\end{array}$




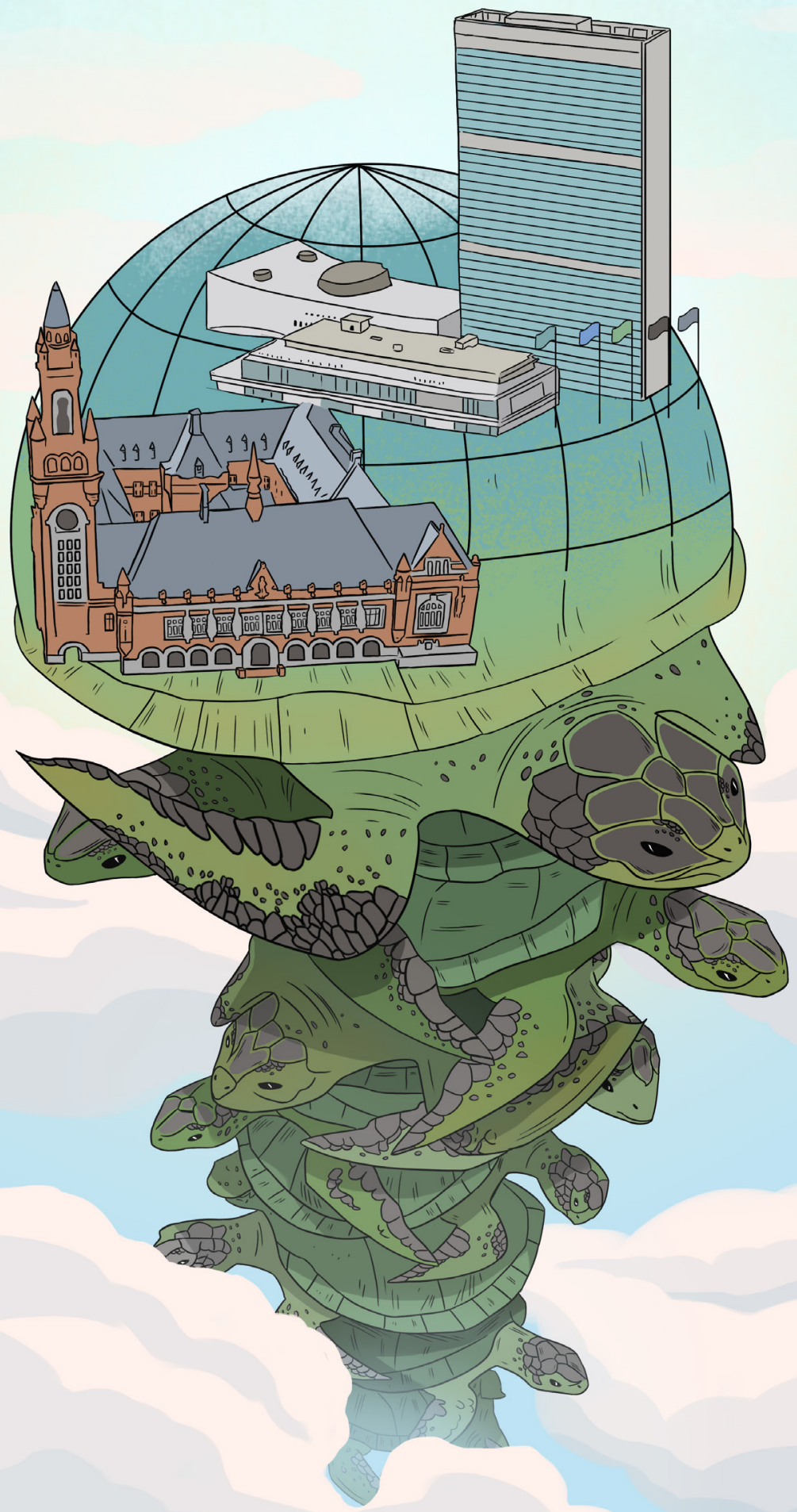




\section{Turtles All the Way Down}

A scientist once gave a public lecture on astronomy in which he explained how the Earth orbits around the sun and how the sun, in turn, orbits around our galaxy. At the end of it, an old lady stood up at the back of the lecture hall and said: 'what you have told us is rubbish. The world is really supported on the back of a giant turtle.' With a superior smile, the scientist responded, 'what is the turtle standing on?'-'You're very clever, young man, very clever' retorted the old lady. 'But it's turtles all the way down!'1

Just as planet Earth does not fall from its position without an infinite tower of giant turtles, the meaning of legal norms, and thus the extent of legal determinacy, does not depend on a stabilising background structure. The frame left open by the law can, for instance, be determined neither by rules of interpretation nor by theories that supposedly work in the background of legal practice. Instead, the stabilising forces that exercise their constant gravitational pull on planet Earth-the sun, the moon, other planets, and countless stars-hide in plain sight. Similarly, we do not have to look any further than to legal practice-the daily work and beliefs of practising lawyers, judges, academics, diplomats, and politicians-to find the sources of stability in international law. To look any further would be a mistake, as legal meanings are exclusively a product of practice. Giant turtles, rules of interpretation, and theories allegedly guiding legal practice are unable to stabilise planet Earth or legal meanings, respectively.

\section{I.A The Research Question and Its Relevance}

In this study, I try to answer the question, 'what is the extent of determinacy of international law?' Related, but different, questions would be 'how much discretion do judges have when applying international law?' or 'how wide is the frame left open by international law when applied to specific situations?' The first question was chosen because it is broader. The extent of determinacy depends not only on legal interpretation but on other questions as well, such as whether there is any valid law that can be interpreted in the first place. 
Before defining the relevant terms in detail-an endeavour not without methodological challenges-, the question of why the chosen research question even matters arises. The thesis at hand does only marginally touch on any of the potential consequences of legal (in)determinacy. However, it is rooted in an interest that goes beyond the purely epistemological aspect of the research question. While the consequences of legal (in)determinacy are not within the scope of the present study, they are the principal reasons for its relevance.

One of the main reasons why the extent of legal determinacy matters is that legitimacy matters. ${ }^{2}$ There are widely diverging views on the relation between (in)determinacy and legitimacy. Some critical legal scholars insist that the liberal conception of the rule of law cannot meet its standard of legitimacy because no existing legal system is sufficiently determinate. ${ }^{3}$ According to the most commonly held view, however, some discretion exercised by law-appliers does not diminish the law's legitimacy. H.L.A. Hart argued that because of the inevitable 'penumbra of uncertainty' that surrounds all legal rules, their application involves a limited amount of discretion. ${ }^{4} \mathrm{~A}$ 'jurists' heaven of concepts' in which rules can be formulated that regulate every possible situation in advance is not only unachievable but also undesirable. Some issues are best settled when they arise in a specific case. Discretion in the process of law-applying is thus not only unavoidable but a condition for its legitimacy. ${ }^{5}$ However, according to this widely held view, the leeway of

2 The term 'legitimacy' is understood here as it is used in political philosophy: a legal decision is legitimate if it provides a prima facie moral obligation to obey. JOSEPH RAZ, The Morality of Freedom (Oxford University Press 1986) 101; KENNETH KRESS, 'Legal Indeterminacy' (1989) 77 California Law Review 283, 285.

3 'Legal doctrine is far more indeterminate than traditional theorists realize it is. If traditional legal theorists are correct about the importance of determinacy to the rule of law, then-by their own criteria-the rule of law has never existed anywhere.' JOSEPH W SINGER, 'The Player and the Cards: Nihilism and Legal Theory' (1984) 94 Yale Law Journal 1, 14. 'My argument is that a distinction between rule making and rule applying cannot be made to legitimate the coercive power of judges (...). In other words, this version of liberal thought has been unsuccessful in the attempt to use a theory of rules to transfer the postulated legitimacy of decision based on consent to the judicial administrators of a body of legal rules.' DUNCAN KENNEDY, 'Legal Formality' (1973) 2 The Journal of Legal Studies, 351, 354.

4 HERBERT L A HART, 'Positivism and the Separation of Law and Morals' (1958) 71 Harvard Law Review 593, 607.

5 HERBERT L A HART, The Concept of Law ( $3^{\text {rd }}$ edn, Oxford University Press 2012) 130. For a similar view, see JEREMY WALDRON, 'Vagueness and the Guidance of Action' in Andrei Marmor and Scott Soames (eds), Philosophical Foundations of Language in the Law (Oxford University Press 2011) 82; also TIMOTHY ENDICOTT argues that a high degree of legal determinacy does not necessarily serve justice. TIмOTHY A о ENDICOTT, Vagueness in Law (Oxford University Press 2000) 189-190. 
judges and others applying the law is limited to the penumbra of uncertainty that surrounds the stable core of the meaning of legal rules. ${ }^{6}$

Legal determinacy in all cases is thus not necessarily worth striving for. Whether the idea that judges are merely 'la bouche de la loi' 7 is a naive dream or rather a nightmare is debatable. It is worth noting that Frederick the Great and Napoleon, not exactly the kind of men who come to mind when we think about legitimacy today, both unsuccessfully tried to prohibit the interpretation of statutes. ${ }^{8}$ Under Joseph Raz's account of legitimate authority, such a prohibition, if it were possible, would undermine a court's legitimacy. According to Raz's normal justification thesis, Anne has legitimate authority over Harry if he is more likely to comply with reasons that apply to him (other than Anne's directives) if he accepts Anne's directives as authoritatively binding and tries to follow them rather than trying to follow the reasons that apply to him directly. ${ }^{9}$ Due to their striving for impartiality, their training and experience, judges are arguably able to help individuals to better comply with reasons that apply to them. Hence under such an account, far from delegitimising judicial law-making, wide discretion may enhance courts' legitimacy. ${ }^{10}$

International lawyers are less willing to accept wide discretion in adjudication than municipal law scholars. ${ }^{11}$ The ICJ has repeatedly emphasised its role as merely applying the law, thereby endorsing a clear separation between international law and non-legal considerations. In the South West Africa case (1966), the ICJ held that nothing that is not already contained in the law can be taken into consideration, as the ICJ 'is a court of law, and can take account of moral principles only in so far as these are given a sufficient expression in legal form.' ${ }^{22}$ Hence the ICJ's role is clear: '[a]s is implied by the opening phrase of Article 38, paragraph 1, of its Statute, the Court is not a legislative body. Its duty is to apply the law as it is, not to make it.'13 This view was confirmed in the Fisheries Jurisdiction cases (1974), where the Court assessed the effects of

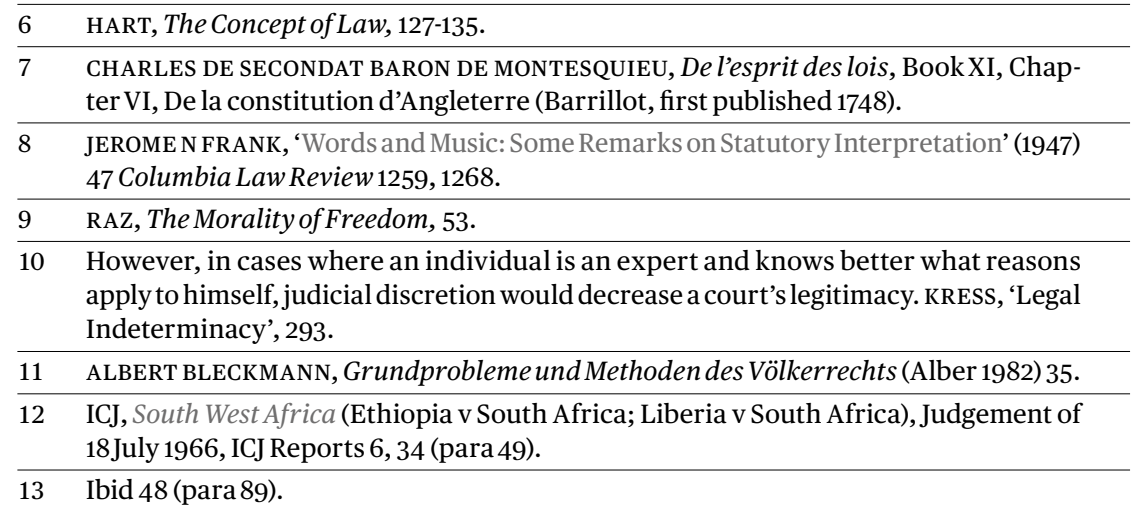


the then ongoing third UN Conference on the Law of the Sea on the dispute at hand. It held that ' (...) the Court, as a court of law, cannot render judgment sub specie legisferendae, or anticipate the law before the legislator has laid it down.' 14 In the Gulf of Maine case (1984), the Court refused to base its decision on anything other than what it considered strictly legal considerations:

It should be emphasized that these fishing aspects (...) may require an examination of valid considerations of a political and economic character. The Chamber is however bound by its Statute, and required by the Parties, not to take a decision ex aequo et bono, but to achieve a result on the basis of law. 15

Judicial reasoning is portrayed as being clearly separate from moral, economic, or political considerations. In these cases, the Court seemed to take a restrictive view on the extent of discretion in adjudication. ${ }^{16}$

This, however, is not the view most international lawyers hold today. Instead, the existence of discretion in the application of international law is openly acknowledged. ${ }^{17}$ Yet, many international lawyers are unwilling to declare that law-appliers enjoy completely unconstrained discretion. There-

14 ICJ, FisheriesJurisdiction (Federal Republic of Germany v Iceland), Judgement of 25July 1974, ICJ Reports 175, 192 (para 45).

15 ICJ, Delimitation of the Maritime Boundary in the Gulf of Maine Area (Canada v United States of America), Judgement of 12 October 1984, ICJ Reports 246, 278 (para 59); the PCIJ already drew a sharp line between law and non-law: ' $[t]$ he Court, in interpreting Part XIII, is called upon to perform a judicial function, and, taking the question actually before it in connection with the terms of the Treaty, there appears to be no room for the discussion and application of political principles or social theories, of which, it may be observed, no mention is made in the Treaty.' PCIJ, Competence of the International Labour Organization to Regulate, Incidentally, the Personal Work of the Employer, Advisory Opinion of 23July 1926, Series B, No 13, 6, 23 (para 50); similarly, in the Free Zones case, the PCIJ held that '[s] uch questions [regarding tariff exemptions] are outside the sphere in which a Court of Justice, concerned with the application of rules of law, can help in the solution of disputes between two States.' PCIJ, Case of the Free Zones of Upper Savoy and the District of Gex (France v Switzerland), Judgement of 7June 1932, Series A/B 46, No 17, 97, 162 (para 202).

16 MARTTI KOSKENNIEMI, From Apology to Utopia: The Structure of International Legal Argument (first published 1989, Cambridge University Press 2005) 30-33.

17 ULF LINDERFALK succinctly sums up the most widespread view: '[t]he exercise of discretion is a central feature of legal decision-making.' ULF LINDERFALK, 'Why Should We Distinguish between the Exercise of Discretion and Interpretation?' (2019). According to an arbitral tribunal with jurisdiction under UNCLOS, discretion exists but is confined by law: '(...) the Tribunal's discretion must be exercised within the limits set out by the applicable law.' PCA, Arbitration between Barbados and the Republic of Trinidad and Tobago, Relating to the Delimitation of the Exclusive Economic Zone and the Continental Shelfbetween Them, Decision of 11 April 2006, XXVIII Reports of International Arbitral Awards, 147, 243 (para 373). 
fore, they attempt to account for the exercise of discretion by making it subject to criteria. 18

The greater reluctance of international lawyers to accept wide discretion compared to their municipal colleagues has several reasons. First, wide and unconstrained discretion in the application of international law is problematic in an environment in which States mistrust each other and international tribunals. A smaller extent of legal determinacy may decrease the predictability of decisions, ${ }^{19}$ giving rise to the fear that judgements go beyond what a State has agreed to. Secondly, while on the domestic level the worry is that (democratically) less legitimised judges rather than the designated lawmakers make law, this concern is accentuated in the international realm where judges get elected by a majority of other States' votes. ${ }^{20}$ Thirdly, the stakes are often higher on the international compared to the national stage; wide judicial discretion in border delimitation cases or questions concerning the legality of nuclear weapons is harder to accept than leeway in the domain of traffic tickets. These considerations explain why international lawyers take a more restrictive view on the issue of judicial discretion, and thus on the extent of legal determinacy, compared to municipal legal experts. While the question of (in)determinacy is central to both domestic legal systems and international law, it is an even more pressing issue in the latter.

18 Various doctrines and principles are used to this end: the concept of equity in THOMAS COTTIER, Equitable Principles of Maritime Boundary Delimitation: The Quest for Distributive Justice in International Law (Cambridge University Press 2015) 518; the concept of good faith in ULF LINDERFALK, 'Good Faith and the Exercise of Treaty-Based Discretionary Powers' (2016) the abuse of rights doctrine in ERIC DE BRABANDERE, 'Good Faith, Abuse of Process, and the Initiation of Investment Treaty Claims' (2012) 3 Journal of International Dispute Settlement 609; general principles recognised by civilised nations in STEPHAN W SCHILL, 'General Principles of Law and International Investment Law' in ERIC DE BRABANDERE / TARCISIO GAZZINI, International Investment Law: The Sources of Rights and Obligations (Martinus Nijhoff 2012) 144; respect for the parties' intentions in ERIC DE BRABANDERE / ISABELLE VAN DAMME, 'Good Faith in Treaty Interpretation' in Andrew D Mitchell, Muthucumaraswamy Sornarajah, and Tania Voon (eds), Good Faith and International Economic Law (Oxford University Press 2015) 53; on how modern international lawyers try to deal with discretion in general, see ULF LINDERFALK, 'Why Should We Distinguish between the Exercise of Discretion and Interpretation?'.

19 HERSCH LAUTERPACHT, The Development of International Law by the International Court (Stevens \& Sons 1958) 75-77.

20 For a sceptical voice regarding judicial law-making on the domestic level, see CHRISTOPHER F ZURN, Deliberative Democracy and the Institutions of Judicial Review (Cambridge University Press 2009) 5 ; in 2018, the Swiss electorate voted on a popular initiative with the unofficial title 'no foreign judges'. Even though it aimed at elevating Swiss constitutional law above international law, uneasiness about 'foreign judges' meddling with the domestic political decisions of an independent State served as the inspiration for its deceptive title. 
The second main reason why the research question at hand matters is that the extent of legal determinacy strongly influences the methods used in law. The bread and butter of lawyers and legal scholars is to make arguments about the (il)legality of a particular situation. This rests on the assumption that law is not indeterminate in all cases. If it were, no distinction between legality and illegality could ever be drawn. The arguments put forward on a daily basis by practising lawyers, judges, and academics do not require that law is always determinate. Quite to the contrary, uncertainty in the law is the starting point of any jurist's work. However, the main question asked in the legal disciplinewhether the circumstances of a case are in conformity with the law-only makes sense if the law is not indeterminate in all cases. While some legal uncertainty guarantees the continued existence of a lucrative job market for jurists, if law were indeterminate in all cases, it would seem questionable why anyone should employ a lawyer rather than a political scientist or moral philosopher.

It thus becomes clear that the greatest threat in terms of legitimacy and methodology is posed by theses stipulating that law is indeterminate in all cases. This is the first reason why a large part of the study at hand will be devoted to the structural indeterminacy thesis, a theory making precisely that point. ${ }^{21}$ The second reason for focusing in detail on the structural indeterminacy thesis is that it is the most controversial among the different (in)determinacy theses. Not a single international lawyer today would claim that there are no uncertainties whatsoever in international law. Everyone from first-year law students to the most experienced judges knows that international law is full of vagueness and ambiguities. However, few would be willing to accept the radical claims entailed by the structural indeterminacy thesis. The third reason why I will focus on the structural indeterminacy thesis as mainly developed by David Kennedy and Martti Koskenniemi is that it has not been adequately addressed in legal scholarship. In a study on the reception of Koskenniemi's From Apology to Utopia, Jean d'Aspremont shows how mainstream legal scholars today often refer to the structural indeterminacy thesis while their approach, after an initial phase of perplexity about Koskenniemi's work, has been to revert to 'business as usual'.22 In a similar vein, Kennedy writes that for critically minded international lawyers

(...) it has been tempting to treat [From Apology to Utopia] as a given, a rock to be digested or maneuvered around, rather than a provocation to

21 The two most influential works advancing the structural indeterminacy thesis in international law are DAVID KENNEDY, International Legal Structures (Nomos 1987); and MARTTI KOSKENNIEMI, From Apology to Utopia.

22 JEAN D'ASPREMONT, 'Martti Koskenniemi, the Mainstream, and Self-Reflectivity' (2016) 29 Leiden Journal of International Law 625, 638. 
engage and revise. I have often seen From Apology to Utopia cited for some general proposition like 'international law moves back and forth from apology to utopia' or 'international legal argument is indeterminate and unpersuasive.' This is too bad. ${ }^{23}$

With a few notable exceptions, 24 there are thus roughly two kinds of approaches that have been taken towards the structural indeterminacy thesis. Mainstream scholars pretend to have gotten over it by either ignoring it or putting Kennedy and Koskenniemi in a footnote while the rest of their publication reads as if the author had never heard of critical legal scholarship. A minority of international legal scholars has tried to build on the structural indeterminacy thesis, working out its consequences. Unfortunately, most of them have done so in an uncritical way, i.e. uncritical towards its foundational works. In the present thesis, I hope to be able to take the structural indeterminacy thesis as seriously as it ought to be taken while analysing it in a critical spirit. In so doing, I try to escape the 'business as usual' trap that mainstream scholars have fallen into while also evading the 'uncritical critical' pitfall some international lawyers seem to be stuck in.

One might ask why I pay so much attention to the structural indeterminacy thesis, which was mainly developed in the late 1980s. The main reasons are that its analysis still has the same critical bite today and that, despite many short review articles, 25 the structural indeterminacy thesis has never been critically scrutinised in detail. ${ }^{26}$ Since the central question that international

23 DAVID KENNEDY, 'The Last Treatise: Project and Person (Reflections on MARTTI KosKENNIEMI's From Apology to Utopia)' (2006) 7 German Law Journal 982, 991.

24 There are some promising critiques of the structural indeterminacy thesis. The interesting publications are, however, all in the form of review articles. There is no monograph-length critical analysis dealing with the structural indeterminacy thesis on more than a few pages. For what I consider the most plausible critique of KENNEDY and KOSKENNIEMI's work, see Section II.B.2.

25 See ibid.

26 THE CRITICAL LEGAL STUDIES MOVEMENT, on the other hand, has been scrutinised thoroughly. Hence, I shall not deal with CLS writings directly but only treat their arguments as they appear in the literature on international law, mostly as they are presented in the structural indeterminacy thesis as put forward by DAVID KENNEDY and MARTTI KOSKENNIEMI. It is surprising that, despite the continued interest in the structural indeterminacy thesis among international lawyers, it has not been scrutinised in detail. By doing precisely this, I hope to be able to fill a gap in international legal scholarship that has remained open for too long. For some of the most important criticisms of the indeterminacy claim of CLS scholars, see LAWRENCE B SOLUM, 'On the Indeterminacy Crisis: Critiquing Critical Dogma' (1987) 54 The University of Chicago Law Review 462; KRESS, 'Legal Indeterminacy'; JULES L COLEMAN / BRIAN LEITER, 'Determinacy, Objectivity, and Authority’ (1993) 142 University of Pennsylvania Law Review 549. 
lawyers ask has not changed since the 1980s-namely whether a particular situation is in accordance with international law or not-, the whole enterprise is still based on the same assumption, i.e. that international law is not structurally indeterminate (and thus not indeterminate in all cases). At the same time, most of today's international lawyers have the impression of having overcome Kennedy and Koskenniemi's work. However, they have not. Everybody seems to have heard of the structural indeterminacy thesis, but most possess only superficial knowledge about it. Approvingly quoting critical international legal scholars while making a classical doctrinal argument in the same paper is thus either based on non-comprehension of the structural indeterminacy thesis or the arrogance of a majority view that does not feel obliged to explain its self-contradictions. Instead of putting Kennedy and Koskenniemi into the footnotes, it would be more honest to simply ignore them. This would send the message that 'they have lost and we have won the (in)determinacy debate'. Victors don't need to be bothered by the ideas of the vanquished. Such an attitude would be preferable to the situation we are in today. Invoking the structural indeterminacy thesis while simultaneously having gone back to 'business as usual' is intellectually dishonest at best. One may accept, reject, or ignore Kennedy and Koskenniemi's thesis. However, one cannot pretend to master and endorse it while self-contradictorily arguing about the legality of $X$ and the illegality of $Y$ without batting an eye. One cannot refer to turtles that stabilise the meanings of international law while simultaneously upholding a theory according to which such turtles cannot existat least not without a convincing explanation. In this sense, it has never been timelier to engage with the structural indeterminacy thesis.

\section{I.B Terminology and Methodological Challenges}

The challenge of providing definitions of the relevant terms at this point is that at a later stage in this study, parts of this representation will need to be rethought. The purpose of defining 'determinacy' and 'indeterminacy' here is to enable the reader to better understand how these concepts have been used in legal writings. The terminological clarifications made in this section will help to categorise the different conceptions of legal (in)determinacy and prepare the ground for analysing their common roots at a later stage. Hence if the following definitions do not yet answer all the follow-up questions a reader might have, this is intended. The aim of this thesis as a whole is to defend a conception of determinacy and indeterminacy of international law which is held neither by mainstream international lawyers nor by critical legal scholars so far. 


\section{I.B.1 The Terms 'Determinacy' and 'Indeterminacy'}

One of the major sources of confusion in the indeterminacy debate is that crucial terms are often used differently. ${ }^{27}$ The purpose of giving a definition of the debate's central concepts is to avoid talking past other authors. Two central terms (indeterminacy and determinacy) and three distinctions (rational/ causal; specific/general; global/local) shall be defined.

Despite the incoherent use of terminology, legal theorists usually say that the law is indeterminate if a legal question does not have one correct answer. ${ }^{28}$ I will follow this definition and thus call law 'determinate' only if there is a unique correct answer to a legal question, and 'indeterminate' if this is not the case. I use the expression 'legal indeterminacy' to refer to any indeterminacy occurring in law, no matter whether the reasons for the law's indeterminacy are, for instance, found in language or in the law itself. 'Linguistic indeterminacy' is used to refer to uncertainties about the application of linguistic expressions that may lead to legal indeterminacy. It is important to note that determinacy and indeterminacy occur in the application of the law or linguistic expressions to certain cases. 'Vagueness' will be used as an umbrella term for all uncertain features of the law and of other linguistic expressions. A legal norm or expression that is not applied to any specific case can thus be vague but not indeterminate. It only makes sense to refer to the (in)determinacy of a norm when it is applied to a particular case. So, for instance, Article 51 of the United Nations Charter contains vague terms (such as 'self-defence', 'armed attack', 'occurs') but is only indeterminate, if at all, when applied to borderline cases (e.g. 'did the events of $9 / 11$ constitute a sufficient basis for invoking Article 51?’). ${ }^{29}$ To avoid convoluted formulations, it will not be mentioned all the time that law can only be (in)determinate when applied to a particular case.

27 While most scholars, for example, only distinguish between determinacy and indeterminacy, some also refer to the concept of 'underdeterminacy'. solum, 'On the Indeterminacy Crisis', 473; for an argument against the use of the concept of 'underdeterminacy', see BRIAN LEITER, Naturalizing Jurisprudence: Essays on American Legal Realism and Naturalism in Legal Philosophy (Oxford University Press 2007) 13. At worst, 'indeterminacy' is used as a synonym for wholly different concepts, e.g.: " [a]mbiguity” is used here to cover vague, incomplete, inconsistent, indeterminate or open-ended language.' sUSANNE T HANSEN, 'Taking Ambiguity Seriously: Explaining the Indeterminacy of the European Union Conventional Arms Export Control Regime' (2016) 22 European Journal of International Relations 192, 195.

28 ENDICOTT, Vagueness in Law, 9; KRESS, 'Legal Indeterminacy', 283; BRIAN BIX, Law, Language, and Legal Determinacy (Oxford University Press 1993) 1.

29 My usage of the terms is aligned with the way the majority of legal theorists uses them, such as defined in ENDICOTT, Vagueness in Law, 9. 
To make a statement about the extent of determinacy of the law is to say something about the extent of determinacy of the class of legal reasons. To state, for example, that the law is indeterminate is to make the point that the class of legal reasons is indeterminate. The class of legal reasons includes, first, the legitimate sources of law; second, the legitimate methods of interpreting the sources, including the legitimate ways of legal reasoning (such as deductive logic and reasoning by analogy); third, the legitimate ways of characterising the facts of a case as legally significant. Determinacy and indeterminacy may arise from any of these three components of the class of legal reasons. ${ }^{30}$

This definition gives rise to the follow-up question of what constitutes a 'legitimate' source of law, method of interpretation, or way to ascertain the legally relevant facts. Can a class of legal reasons be legitimate in an objective way, i.e. independently of whether legal experts consider it legitimate? Or is a particular class of legal reasons legitimate only if all or most jurists agree about it? This question will be analysed in detail in the second main part of the present thesis (II.B). For now, it is sufficient to understand the differences between determinacy and indeterminacy while leaving the follow-up question-whether a given conception of the class of legal reasons is 'legitimate' due to objective factors or subjective acceptance-aside.

The extent of legal determinacy ${ }^{31}$ heavily depends on what one considers to be the law, i.e. one's conception of the class of legal reasons. The same statement can thus mean something very different depending on the definition of the sources of law that the person making the assertion believes in. Take the examples of an exclusive legal positivist who believes that morality is not part of the legitimate sources of law and a non-positivist who is convinced that morality is a legitimate source of law. ${ }^{32}$ By stating that 'international law is determinate', the exclusive legal positivist may want to express that the sources of international law that are listed in Article 38(1) of the ICJ Statute (an enumeration not containing morality) are determinate; morality is not needed

30 In BRIAN LEITER's classification, the legitimate ways of legal reasoning are not part of the legitimate methods of interpretation but constitute a fourth class of legal reasons. Given that interpretation and legal reasoning cannot be clearly separated, I treat them together. LEITER, NaturalizingJurisprudence, 9.

31 'The extent of determinacy' is an expression used whenever the range of possible options is left open (from determinacy in most cases to indeterminacy in all cases). It is used instead of 'the extent of (in)determinacy' to improve readability.

32 An example of an exclusive legal positivist is JOSEPH RAZ. See, for example, JOSEPH RAZ, The Authority of Law: Essays on Law and Morality (Oxford University Press 1979) 47. RONALD DWORKIN, legal positivism's most influential critic, opposed the view that the existence and content of law can always be determined by referring to its sources without relying on moral standards. RONALD DWORKIN, Taking Rights Seriously (first published 1977, Bloomsbury 2013) 38-39. 
to arrive at the only legally acceptable outcome. The non-positivist stating that 'international law is determinate' may want to express that the sources of international law-which in his understanding include morality-are sufficient to arrive at the only legally acceptable outcome. These two scholars thus superficially seem to agree on the extent of international law's determinacy ('it is determinate'), but given their fundamentally different conception of the sources of international law, they cannot be said to actually agree. 33 Their assertions about the extent of legal determinacy would be comparable only if they agreed on a definition of the legitimate sources of law. This applies not only to the sources of law but to the whole class of legal reasons (sources, methods of interpretation, and characterisation of the facts of a case as legally significant). If two scholars agreed e.g. on the sources of law but disagreed about the legitimate methods of interpretation, the same problem would arise. Superficially comparing statements by scholars about the extent of legal determinacy should thus be avoided.

\section{I.B.2 Different Forms of (In)determinacy}

Three distinctions are relevant for the concept of legal (in)determinacy. The first one is between rational and causal determinacy and indeterminacy. It reflects the distinction between justification and causality. The law is rationally determinate if the class of legal reasons (whatever one's conception of it looks like) is sufficient to justify only one solution to a case. The law is causally determinate if the law causally determines only one outcome, i.e. if the class of legal reasons is causally sufficient to determine only one answer to a case. The law can, for instance, not be causally determinate if a judge is biased or dishonest. As will be seen, the debate about legal determinacy focuses on rational, not causal, determinacy. Legal theorists are mostly interested in the question of whether the law can justify one correct solution or not. ${ }^{34}$ The same applies

33 For LEITER, this means 'that the real debate about indeterminacy is, in fact, coextensive with the debates already central to analytic jurisprudence, for example, about the legitimate sources of law and the legitimate ways of interpreting statutes or precedents.' BRIAN LEITER, 'Legal Indeterminacy' (1995) 1 Legal Theory 481, 492.

34 If the law is indeterminate, it can justify all possible solutions on the surface. This, however, means that it ultimately cannot constrain any legal outcome. MARTTI KOSKENNIEMI, who upholds the structural indeterminacy thesis, thus argues that the outward show of legal reasoning is able to justify every possible outcome while the political philosophy underlying it cannot justify any legal decision: '(...) legal argument proceeds by establishing a system of conceptual differentiations and [can be used] in order to justify whatever doctrine, position or rule (i.e. whatever argument) one needs to justify.' KosKENNIEMI, From Apology to Utopia, 10. This is what happens on the surface, while in the background, liberalism is 'ultimately (...) unable to coherently justify or criticize instances of State practice.' Ibid 6-7. 
for the present study, even though many legal theorists would not agree with my understanding of justification. Under what circumstances an answer to a legal question is (considered to be) justified, and therefore rationally determined, is part of my main argument and is not discussed further at this point yet. As the present thesis does not deal with causal determinacy, the distinction between rational and causal determinacy mainly helps to understand what will not be treated. Henceforth when referring to 'legal (in)determinacy', I mean rational legal (in)determinacy unless otherwise stated. 35

Law can be indeterminate for two different kinds of reasons. The first category of such reasons comprises those that are specific to law. An example of specific indeterminacy would be the claim that law is indeterminate due to the existence of conflicting, but equally correct, methods of legal interpretation. ${ }^{36}$ Second, the law can be indeterminate due to those deficiencies it shares with all semantic or rational content. An example of such general indeterminacy is the claim that the law is indeterminate due to the 'open texture' of language itself. 37

The third distinction is the one between local and global (in)determinacy. If the law is globally indeterminate, it is insufficient to justify only one outcome in any case. If the law is locally indeterminate, it is merely insufficient to justify only one outcome in a specific set of cases (often called 'hard cases'). 38 H.L.A. Hart, for example, argued that the law is locally indeterminate. He maintained that the law is only indeterminate in 'hard cases', but determinate in 'plain cases' (also called 'easy cases'). ${ }^{39}$ I will argue that nobody since the 1920 s at the latest has explicitly defended the view that law is globally determinate, i.e. that there is one right answer to all legal questions. Given that law is determinate if its application leads to one correct solution, it is unhelpful to state that the law is 'fully', 'somewhat' or 'rather' determinate.40 Law can be locally or globally determinate, but in those cases where it is determinate, it is not a matter of degree.

\footnotetext{
35 LEITER, NaturalizingJurisprudence, 9-11.

36 See, for instance, KARL N LLEWELLYN, 'Remarks on the Theory of Appellate Decision and the Rules and Canons about How Statutes are to be Construed' (1950) 3 Vanderbilt Law Review 395.

37 HART, The Concept of Law, 127-128; LEITER, NaturalizingJurisprudence, 11.

38 LEITER, NaturalizingJurisprudence, 11.

39 HART, The Concept of Law, 126; KRESS, for instance, uses the expression 'easy cases'. KRESS, 'Legal Indeterminacy'.

40 SUZANNA SHERRY, for instance, writes that '[l]aw, especially constitutional law, and especially the hard cases that reach the Supreme Court, is neither fully determinate or fully indeterminate.' SUZANNA SHERRY, 'Putting the Law Back in Constitutional Law’ (2009) 25 Constitutional Commentary 461, 461.
} 


\section{I.B.3 Predictability and Determinacy}

The extent of legal determinacy is linked to, but distinct from, the predictability of legal decisions. Legal predictability may depend, amongst other factors, on the extent of legal determinacy. The distinction between causal and rational determinacy helps distinguish legal determinacy from predictability. If the law is rationally and causally determinate, this necessarily means that the law is predictable, given that the class of legal reasons can only justify one correct solution, which causally leads judges to adopt the only correct decision. ${ }^{11}$ If the law is rationally determinate, but causally indeterminate because the deciding judge is biased, the judgement is only predictable if the judge's bias itself is predictable.

The extent of legal determinacy and the predictability of decisions are thus only linked in the case where the law is rationally and causally determinate. Rational determinacy alone does not guarantee the predictability of decisions. Conversely, if legal decisions are predictable, this does not necessarily mean that the law is rationally determinate. It may be that the law is rationally indeterminate but the bias of the judge determining the outcome is known. If legal decisions are unpredictable, this is not a reliable indicator of rational legal indeterminacy either: it may be that law is rationally determinate while causally indeterminate (and the judge's bias determining the outcome is unknown). Given that there is only one necessary link between predictability and the extent of legal determinacy, the former does not play a crucial role in the present research.

\section{I.C Agenda and Outline}

This study approaches the question of (in)determinacy of international law in two main parts. The first part categorises the different types of theses about the extent of legal determinacy. The aim is not to provide a historical overview of all the (in)determinacy theses that have been put forward. Instead, the four categories, which also form the sections of the first main part, serve to capture the most widespread and influential arguments about the extent of determinacy of international law. First, the imaginary global determinacy thesis shall be discussed (II.A.1). In a second section, legal indeterminacy due to linguistic reasons will be examined (II.A.2). A third section is devoted to indeterminacy arising from valid international legal norms (II.A.3). The structural

41 This assumes that the jurist predicting the case is familiar with the law. 
indeterminacy thesis, which rejects the existence of valid international legal norms, shall be addressed in the last section of the first main part (II.A.4). This categorisation provides an overview of the majority of (in)determinacy theses put forward in international law within the period considered, i.e. since 1920.

The different (in)determinacy theses discussed in the present study date from roughly the last hundred years. Over this period, the legal (in)determinacy debate has mainly been driven by two waves, the first one being legal realism, the second one the critical legal studies movement. Even though both originally developed in the context of domestic law, they found their way into international legal scholarship as well. Except for the section on the structural indeterminacy thesis, which focuses on David Kennedy and Martti Koskenniemi's theory, the sections of the first main part are not centred around individual legal scholars. However, two of the most important proponents of American legal realism, Karl Llewellyn and Jerome Frank, will frequently be referred to throughout this study. Moreover, Hans Kelsen and Myres McDougal will play a significant role in this thesis.

The first reason for this selection is simply that these jurists seem to have thought harder than most about legal (in)determinacy. Secondly, their writings have been influential. Readers are thus likely to be familiar with their publications from other discussions, which makes their views more relatable. Thirdly, the contributions by Llewellyn, Frank, Kelsen, and McDougal are multi-layered and cannot be productively reduced to a few sentences. Hence the extent of attention I allocate to these authors allows me to portray their (in)determinacy theses in a non-reductive way. Because statements about the extent of legal determinacy are not superficially comparable, analysing the views of a few scholars thoroughly is more fruitful than discussing a large number of scholarly arguments only briefly and superficially. A fourth reason why these scholars were chosen is that they all approached the topic of legal (in)determinacy from fundamentally different angles. Lastly, this study is not an exhaustive treatment of the different (in)determinacy theses put forward over the last hundred years. Instead, some of the most important contributions shall be highlighted while others necessarily have to be left aside. Focusing on the scholars mentioned above allows me to include examples from different periods since the 1920 s.

When justifying the choice of their time frame, some authors seem to feel obliged to argue that the selected period is clearly the most suitable one. I do not feel compelled to do so. The subject of indeterminacy of international law might well be productively approached by choosing another time frame. All I argue is that analysing the views of some scholars who wrote within the last one hundred years is one among several viable and meaningful 
choices. ${ }^{42}$ The selection of this period is linked to my focus on Western legal scholars. All those who play an important role in this thesis are either from Europe or North America or have at least been educated there. I do not claim to analyse the global discourse on indeterminacy of international law over the last hundred years. Fortunately, a narrow focus on the discourse in the West is no vice as long as it is not claimed to represent a global discussion.

Given my focus on Europe and North America (the latter mainly meaning the East Coast of the United States), starting around the 1920s is helpful. Back then, Hans Kelsen's 'deconstructive arguments hit orthodox doctrine harder than those of most post-modernists.' 43 This is unsurprising, given that in his Das Problem der Souveränität und die Theorie des Völkerrechts of 1920, Kelsen argued for an early version of the structural indeterminacy claim, thereby foreshadowing Kennedy and Koskenniemi's theses more than 60 years later. Additionally, Kelsen's critique of then-prevalent views on the extent of determinacy arising from legal interpretation and fact-ascertainment serve as a useful starting point for the present analysis. Choosing a radical, skilful, and influential critique as the beginning of the present study is also the approach I take for North American scholarship. Like Kelsen, the American legal realists did not only intend to make minor adjustments to the then orthodox understanding of legal determinacy but proposed a radically different view. As Llewellyn and Frank were two of the leading proponents of American legal realism, their conceptions of (in)determinacy serve as a helpful starting point for the present research. The most important reason why this study starts in the 1920 (and in the case of the United States mainly in the 1930s) is that my aim is not to provide a historical overview of all indeterminacy theses but to highlight some of those that are still taken seriously today. In the $21^{\text {st }}$ century, after a century of legal realist critique, nobody defends the conceptions of determinacy that Kelsen, Llewellyn, and Frank attacked anymore. These three authors, however, are still relevant for present-day discussions, whether directly through their writings or indirectly through their strong influence on subsequent scholarship.

The reason why I mainly focus on explicit theories of legal (in)determinacy but neither on decisions of courts nor on doctrinal scholarly publications will be explained in the section on global legal determinacy (II.A.1).

42 On the unavoidable subjectivity in any periodization, see OLIVER DIGGELMANN, 'The Periodization of the History of International Law' in Bardo Fassbender and Anne Peters (eds), The Oxford Handbook of the History of International Law (Oxford University Press 2012) 1001.

43 Jörg KAMMERHOFER, 'Hans Kelsen in Today's International Legal Scholarship' in JÖRG KAMMERHOFER and Jean d'Aspremont (eds), International Legal Positivism in a PostModern World (Cambridge University Press 2014) 82. 
The purpose of the first main part (II.A) is not only to serve as a background to the analysis in the second main part (II.B) but to advocate for a more meaningful categorisation of (in)determinacy theses in international law. The debate about the extent of determinacy of international law is a terminological mess. Arguing, for instance, that international law is indeterminate due to vagueness and ambiguity of language is an altogether different point than the claim that there cannot be a coherent account of validity in international law. Yet, both ideas are often subsumed under the term 'indeterminacy of international law' without making a clear distinction as to its roots. ${ }^{44}$ Therefore, in order to stop talking past each other, it is crucial to make the above-mentioned terminological distinctions. Whether international law is, for instance, locally indeterminate for linguistic reasons or globally indeterminate due to structural deficiencies of the prevalent background theory matters, and we thus need to use different expressions for different concepts. By proposing to sort (in)determinacy theses in international law into these four categories, I hope to contribute to enable scholars to be more precise. Thereby, I expect to facilitate a debate that is not bound to fail from the start because its participants use the same terms to talk about different ideas.

A critical analysis of the existing (in)determinacy theses constitutes the core of the present study (II.B). The second main part deals with the four types of (in)determinacy theses as they are presented in the first main part. Its first section (II.B.1) raises the question of where legal meanings are produced and what stabilises them. This allows me to preliminarily respond to the first three (in)determinacy theses (the global determinacy thesis, linguistic indeterminacy, and indeterminacy arising from the composition of norms). As the structural indeterminacy thesis requires separate treatment, an entire section is devoted to its critical analysis (II.B.2). In a final section, I argue that most legal (in)determinacy theses have been wrongly framed, and propose an alternative (II.B.3). This section should be read as complementing the analysis in (II.B.1), thus contributing to a fuller picture of how legal meanings are determined.

44 BECKETT, for instance, confuses what I call 'linguistic indeterminacy' with the 'structural indeterminacy thesis'. Showing that linguistic expressions have a stable core of meaning is not an attack on the structural indeterminacy thesis, which does not pertain to the uncertainties of language but to the validity of international law. JASON A BECKETT, 'Behind Relative Normativity: Rules and Process as Prerequisites of Law' (2001) 12 European Journal of International Law 627, 643-647. For a similar misunderstanding see also ANDREAS PAULUS, Die internationale Gemeinschaft im Völkerrecht: Eine Untersuchung zur Entwicklung des Völkerrechts im Zeitalter der Globalisierung (CH Beck 2001). 
The second main part aims to shift the focus of research about legal meanings and their limits, i.e. about the extent of legal determinacy. Instead of narrowly focusing on texts, legal norms, interpretive methods, and theories allegedly working in the background of practice, it is crucial to look at practice itself. Because the concrete content of international law seems to float around in empty space, international lawyers feel the necessity to look for some stabilising ground. Often, international lawyers believe to have found stability in the text itself, in interpretive methods, or in a theory that-even though not held by many-can allegedly explain what is really going on in international law. Such accounts make for a compelling story. They seem to explain how international law is stabilised. However, just like the tale about an infinite tower of giant turtles which purportedly stabilises planet Earth, such stories do not identify the real source of stability. The problem with such accounts is that, just like with the turtles, they would need to be based on an infinite regress argument; the stability of a text comes from another text, whose stability is rooted in another one, etc. The force of a theory derives from another theory, which is based on yet another one, and so on. Turtles, texts, and theories all the way down. The only explanation of the stability of legal meanings that ultimately does not end up in an infinite regress is that the source of this stability lies in practice itself. The main aim of this study is thus to portray the extent of legal determinacy as a function of practice. 



\section{Indeterminacy of International Law?}

\section{II.A Types of Legal (In)determinacy Theses}

\section{II.A.1 At One End of the Spectrum: The Imaginary Global Determinacy Thesis}

Andrea Bianchi identifies the belief that 'problems are supposed to have one correct legal solution' as a view held by 'mainstream' international lawyers. 45 If this is understood to mean that international lawyers hold an explicit, philosophically grounded, belief in global determinacy, his statement would be wrong. While laypeople tend to believe that all questions of law have one correct legal answer, ${ }^{46}$ this position has not been explicitly defended by any legal scholar since the 1920 s at the latest. According to Bianchi, his statement does not refer to a conviction that is philosophically grounded but rather to an implicit assumption that is a widespread attitude among traditional international lawyers. What most people do in the profession is not philosophically informed. Hence global legal determinacy is an unarticulated belief that has turned into a habit and eventually into a second skin. ${ }^{47}$

The problem with this statement is that it is difficult to prove. Given that international legal scholarship indeed often takes the shape of suggesting, what is portrayed to be, the best or the only reasonable solution to a doctrinal problem, it is unclear whether this is the result of an underlying conception of legal determinacy or simply a way to formulate one's claim in more persuasive terms. ${ }^{48}$ Ingo Venzke correctly observes that ' $[t]$ he outward show of legal

\footnotetext{
45 ANDREA BIANCHI, International Law Theories (Oxford University Press 2017) 21.

46 JEROME N FRANK, Law and the Modern Mind (first published 1930, Transaction 2009) 5-6.

47 I thank ANDREA BIANCHI for clarifications on this point.

48 ABRAHAM D SOFAER, for instance, makes the following point: ' $[t]$ his paper examines the background of the requirement that pre-emption is restricted to imminent attacks, and argues that the narrow standard properly applies only when a potential victim state can rely on the police powers of the state from which a prospective attack is anticipated.' Is this, according to SOFAER, the only legally correct answer? Or is it based on non-legal considerations? It is difficult to know, given that authors of doctrinal articles in international law hardly ever explicitly discuss where they locate the border between law and non-law, amongst other matters. ABRAHAM D SOFAER, 'On the Necessity of Preemption' (2003) 14 European Journal of International Law 209, 209.
} 
reasoning presents itself as an activity of finding the law that is already out there. There is then no creative part to interpretation-no agency, no politics, and no problem (except for the methodological squabble of how best to interpret).' 49 Conceptions of the extent of determinacy cannot be deduced from court decisions or doctrinal arguments by international lawyers because ' $[t] o$ present claims in international law as the right ones is simply the currency of the game.'50

Doctrinal studies in international law hardly ever contain a methodological introduction in which the adopted conception of (in)determinacy is discussed. Most international lawyers prefer not to deal with the matter. ${ }^{51}$ It is easier to leave the question of legal (in)determinacy untouched, as touching it would invite different kinds of criticisms; if another scholar comes up with a different doctrinal solution, the defence could be to refer to the local indeterminacy of law: 'your solution makes sense, but so does mine, because there is some discretion in the application of law to the present question.' If one's doctrinal solution remains unchallenged, it may be tempting to assume legal determinacy: 'I have found and provided the one right answer.' Under these considerations, it is more convenient for practically oriented international lawyers not to discuss their underlying conception of the extent of legal determinacy.

The (non-)treatment of conceptions of legal (in)determinacy reflects the wide divide between international legal theory and doctrinal discussions in international law. While such conceptions are discussed in detail in the former, they are largely ignored in the latter. This is understandable due to practical considerations, yet methodologically inadequate, given that doctrinal questions of (il)legality are necessarily based on a certain conception of legal (in) determinacy. Meaningful criticism of a judgement for being politically motivated rather than constituting a correct application of the law is, for instance, necessarily based on an idea of the extent of determinacy; it does not make

49 INGO VENZKE, How Interpretation Makes International Law (Oxford University Press 2012) 10.

50 INGO VENZKE, 'Semantic Authority, Legal Change and the Dynamics of International Law' in Patrick Capps and Henrik Palmer Olsen (eds), Legal Authority beyond the State (Cambridge University Press 2018) 112; D’ASPREMONT and MBENGUE similarly argue: '[w]hen it comes to the establishment of the applicable law, the judicial function has continued to be officially portrayed as limited to textual mining, that is, extracting something that is already out there.' JEAN D'ASPREMONT and MAKANE M MBENGUE, 'Strategies of Engagement with Scientific Fact-Finding in International Adjudication' (2014) 5Journal of International Dispute Settlement 240, 243.

51 An important exception is HANS KELSEN's commentary on the UN Charter in which he explicitly defends a conception of local indeterminacy and, consequently, discusses in his doctrinal analysis which options are left open by the law. HANS KELSEN, The Law of the United Nations: A Critical Analysis of Its Fundamental Problems (Stevens \& Sons 1951). 
sense to criticise a judgement for political bias without having a notion of whether or how much 'politics' is needed to fill the discretion left open by law. Even though theoretical discussions have recently gained some ground, traditional international lawyers rarely discuss the methodological presuppositions of their approaches. 52 Doctrinal writings in international law that do not contain any reference to their conception of legal (in)determinacy could thus be criticised for standing on shaky methodological grounds.

Practical necessities emerge as the main reason why court decisions and doctrinal papers are written in a style that implies a belief in determinacy concerning the relevant legal question. If the ICJ holds that an island belongs to one State rather than the other, it would be blatantly unwise for it to do so by referring to its wide discretion in the matter. Since such judgements by international courts are already hard enough to accept for the State that lost the case, at least the belief needs to be upheld that international law is determinate regarding the legal question at hand. Even if the judges in The Hague are fully aware that they have some discretion, they cannot write this in the judgement. International judges thus have strong practical reasons to uphold an outward show of legal reasoning that masks any potential indeterminacy. This is the accepted 'currency of the game', and most international lawyers are aware of it.

International lawyers who argue for a particular doctrine in international law face similar incentives. Apart from the already-mentioned shield against criticism, implying legal determinacy is more convincing than emphasising uncertainties. The point of most doctrinal articles is to convince other international lawyers of adopting one's view on the matter, not to draw post-modern delight from exposing the irreducible uncertainties of law. This function is recognised by other international lawyers, and it is another reason why portraying law as if it were determinate, at least regarding the legal question at hand, is accepted within the profession.

Most international legal scholars who deal with the extent of legal determinacy in a theoretical way are of the view that international law is locally indeterminate. ${ }^{53}$ If doctrinal treatments of international law followed the majority opinion held in international legal theory, several equally correct outcomes would need to be proposed in 'hard cases' where law-appliers enjoy some discretion. A choice would then have to be made between them based on-openly non-legal-considerations. However, this is not what we read in international law journals.

52 BIANCHI, International Law Theories, 23.

$53 \quad$ See Sections II.A.2 and II.A.3. 
Bianchi's assertion that legal determinacy is an unarticulated belief, which has turned into a habit and eventually into a second skin of many mainstream international lawyers, may thus be correct for those who cannot distinguish between the outward show of legal reasoning and the genuine beliefs held by international lawyers. If a jurist only reads cases of international courts and academic articles that doctrinally tackle a legal question, it may very well be that he starts believing that all questions of international law have one correct answer; since everyone always presents the answer to a legal question, all legal problems must have exactly one correct solution indeed. In judgements and doctrinal articles, other opinions are not usually portrayed as equally good options but simply as based on some legal mistake. It is implicit to such a writing style that the law is determinate, at least concerning the question treated in the respective article; other jurists who defend different views are just not skilled or honest enough to recognise the one correct legal solution.

I would argue, however, that such a belief can only persist as long as it remains unarticulated. For many international lawyers, legal theory is not a field that they need to take into consideration in order to be professionally successful. If such practically-oriented international lawyers were pressed to articulate their views on the extent of determinacy of international law, they would not defend a conception of global determinacy. Their unarticulated belief in the one-right-answer thesis is merely upheld because it is a useful attitude for practically inclined international lawyers. Additionally, it is psychologically easier to understand one's solution as the correct answer to the problem rather than as one among many subjective views in a pluralistic universe. What, otherwise, is the point of all the hard work? ${ }^{54}$

54 Any psychological explanation can, however, at best be a partial one. Moreover, referring to psychological motives as a jurist bears the danger of dilettantism; one example is JEROME FRANK's application of the stereotyped psychoanalytical concept of fathersubstitution to explain why lawyers believe in legal determinacy. According to FRANK, infants long for peace, comfort, and protection from the unknown. The child thus craves a stable, controllable world. This craving is satisfied by his reliance on the unmatched, infallible, and omnipotent father. However, as the child grows up, he realises that there is an uncontrollable factor of change and uncertainty in the world and that his father cannot do anything about it. The grown-up unconsciously longs to rediscover a reassuring father figure. In the child's perception, the father's commands appeared to leave no room for doubt, they were certain and predictable. Striving for the emotional state of the child's world, grown-ups project their wishes onto the law. In the legal system, they unconsciously seek to rediscover the predictability, certainty, and authoritativeness that had once been embodied by their father. Hence the myth of legal certainty is upheld. FRANK, Law and the Modern Mind, 19-22. LLEWELLYN maintained that people experience 'emotional dissatisfaction' when they realise that there is not always one correct answer to legal problems. KARL N LLEWELLYN, The Theory of Rules (University of Chicago Press 2011) 128; LLEWELLYN was, however, critical of FRANK's psychoanalytical approach. KARL N LLEWELLYN, 'Law and the Modern Mind: A Symposium' (1931) 31 Columbia Law Review 82, 86. 
There is nothing wrong with such an atheoretical attitude per se; it is understandable that practising lawyers and judges do not have the time to think thoroughly about the extent of legal determinacy that underlies their arguments. It would, however, be a mistake to treat the outward show of legal reasoning by practically-oriented international lawyers as an accurate representation of their beliefs about the (in)determinacy of international law. While I will argue that the formulations used by judges and lawyers when arguing about the outcome of a case constitute more than an inconsequential outward show, court decisions and doctrinal articles are not the appropriate starting point for analysing the different (in)determinacy theses held by international lawyers. A study of the outward show of legal reasoning would lead to the conclusion that international law is portrayed as either not allowing any discretion or only permitting a subjective choice by the law-applier in areas that are clearly delimited by international law. ${ }^{55}$ I submit, however, that such an analysis could not cover the whole range of (in)determinacy theses defended by international lawyers. Part II.A will therefore focus on the writings of scholars who have explicitly dealt with the extent of determinacy of international law.

I have argued that global legal determinacy has not been explicitly defended by any theoretical account since the 1920 s at the latest. Some readers may at this point object that Ronald Dworkin was famous for his elaborate one-right-answer thesis. Dworkin indeed argued that most questions of law have one right answer. ${ }^{56}$ There are, however, two reasons why this study will not discuss Dworkin's thesis in detail. First, it is doubtful whether Dworkin's one-right-answer thesis should even be called a conception of legal determinacy or rather an argument about the determinacy of moral reasons. Dworkin adopted a maximalist definition of what he considered a legal reason, i.e. he took a highly inclusive view on whether moral standards are part of the law. 57 His definition of the class of legal reasons is shared only by very few international lawyers, which renders any meaningful comparison to their conceptions of legal (in)determinacy futile. To deal with Dworkin's thesis would require taking a stance on his peculiar definition of the class of legal reasons, which is beyond the scope of this study. Without such a discussion, treating Dworkin's 'legal' determinacy thesis would amount to analysing whether moral reasons are determinate, i.e. whether there is one correct answer to

\footnotetext{
55 MARTTI KOSKENNIEMI has skilfully analysed the outward show of legal reasoning as, for instance, employed by the ICJ. KOSKENNIEMI, From Apology to Utopia, 41-58.

56 RONALD DWORKIN, A Matter of Principle (Harvard University Press 1995) 119-145.

57 BIX, Law, Language, and Legal Determinacy, 79.
} 
questions involving moral reasoning. This is even more clearly outside the present study's scope. Secondly, even though Dworkin held that most 'hard cases' have one correct solution, he did not defend the view that all legal questions have one correct answer. 58

If at all, a conception of global legal determinacy may only be attributed to international lawyers if their writings as judges or their doctrinal articles are taken at face value. For the reasons outlined above, however, thereby we would only be examining the outward show of legal reasoning. In Part II.A, I am interested in what international lawyers genuinely believe, not in the way they portray the extent of determinacy of international law. That the authentic beliefs of international lawyers about the extent of legal determinacy strongly deviate from what they convey in the outward show of legal reasoning shall be illustrated by the views of Sir Gerald Fitzmaurice.

If anyone appears to have come close to defending a conception of global determinacy of international law, it was Fitzmaurice in his capacity as a judge. However, he also published as a legal advisor and as an academic, which makes him a particularly multifaceted example. ${ }^{59}$ When reading his dissenting opinions, one might think at first that he defended the view that international law is globally determinate. In the 1962 ICJ South West Africa case, the judges Fitzmaurice and Spender attached a joint dissenting opinion in which they stated:

We are not unmindful of, nor are we insensible to, the various considerations of non-judicial character, social, humanitarian, and other, which underlie this case; but these are matters for the political rather than for the legal arena. They cannot be allowed to deflect us from our duty of reaching a conclusion strictly on the basis of what we believe to be the correct legal view. 60

Moreover, even in his capacity as an academic, Fitzmaurice wrote that 'the real fault of lawyers (...) is that they have not, as lawyers, been single-minded

58 DWORKIN, A Matter of Principle, 119-145; JACK M BALKIN, 'Taking Ideology Seriously: Ronald Dworkin and the CLS Critique' (1987) 55 UMKC Law Review 392, 394.

59 FITZMAURICE served as legal adviser to the UK government, was a member of the ILC, judge at the ICJ and the ECtHR, and taught at various universities. ANDREA BIANCHI takes him as an example of an international lawyer with a 'traditional approach'. BIANCHI, International Law Theories, 26-27; MARTTI KOSKENNIEMI refers to him as 'one of the most consistent incarnations of the role of the judge'. KOSKENNIEMI, From Apology to Utopia, 550.

60 ICJ, South West Africa (Ethiopia v South Africa; Liberia v South Africa), Preliminary Objections, Judgement of 21 December 1962, Joint Dissenting Opinion by Sir PERCY SPENDER and Sir GERALD FITZMAURICE, ICJ Reports 465, 466 (emphasis added). 
enough, and have not resisted the temptation to stray into other fields.' ${ }^{61}$ Instead, international legal documents should be interpreted as they stand, without any reference to non-legal considerations. ${ }^{62}$ In his dissent in the Ireland $v$. United Kingdom case decided by the European Commission of Human Rights, Fitzmaurice referred to language dictionaries in order to demonstrate that the interrogation techniques used by the United Kingdom against members of the Irish Republican Army suspected of terrorism could not be defined as 'inhuman treatment' under Article 3 of the ECHR. This, in his view, assured 'the correct handling of languages and concepts'. ${ }^{63}$

The first point that becomes clear is that Fitzmaurice considered it essential to neatly distinguish between legal and non-legal considerations. This view in itself, however, does not amount to a belief in global legal determinacy. Anyone holding a conception either of global determinacy or of local indeterminacy needs to draw a distinction between law and non-law. This distinction is blurred only for those who hold the view that law is globally indeterminate. Hence if someone maintains that law can and should be neatly separated from social, economic, or political considerations, this only tells us that he does not defend a global indeterminacy thesis.

Neither does Fitzmaurice's view on 'the correct handling of languages and concepts' necessarily mean that he defended a conception of global determinacy. To what extent language and concepts can be handled 'correctly' will be discussed in Section II.B.1. The point here is that the belief in the possibility of 'correct' applications of language and concepts does not necessarily imply that all such applications have one correct outcome. Neither can Fitzmaurice's statement, as expressed in the dissenting opinion attached to the South West Africa case, that it is a judge's duty to reach conclusions based on what he believes to be 'the correct legal view' be interpreted as conclusive evidence of his belief in global determinacy. It might as well be that Fitzmaurice simply believed that there was one correct solution to the particular question at hand. Thus as it is so often the case, it is impossible to draw indisputable conclusions about the underlying conception of the extent of legal

61 GERALD FITZMAURICE, 'The United Nations and the Rule of Law' (1953) 38 Transactions of the Grotius Society 135, 142; FITZMAURICE's preference for a separation of legal advisors from policy-makers in foreign ministries is thus not surprising. GERALD FITZMAURICE, 'Legal Advisers and Foreign Affairs' (1965) 59 The American Journal of International Law 72, 77-84.

62 GERALD FITZMAURICE, 'The Law and Procedure of the International Court of Justice: Treaty Interpretation and Other Treaty Points' (1957) 33 British Yearbook of International Law 203, 212.

63 ECOMHR, Ireland v the United Kingdom, Judgement of 18January 1978, Series A 25, Separate Opinion by Judge Sir GERALD FITZMAURICE, 75 (para 25). 
determinacy from the outward show of legal reasoning. Even if Fitzmaurice had unambiguously proclaimed in this context that all questions of international law have one correct answer, such a statement could not be taken at face value, given that he wrote it in his capacity as a judge.

Fitzmaurice is a fitting example of someone who expressed different opinions in his various roles as judge, legal advisor, and academic, and thus illustrates the methodological choice of materials in this study. Wearing the hat of the legal advisor, he was aware that governments 'want to know what the true legal position is, simpliciter.' ${ }^{64}$ As an academic, Fitzmaurice recognised that such a simplistic position might not be attainable. Instead, he had no illusions about the fact that judges may exercise discretion. He maintained, for instance, that the use of a teleological method of interpretation in practice leads to judicial law-making65 and even advised to '(...) steer a middle course between being over-conservative and ultra-progressive' when discretion arises. 66 Fitzmaurice's statements in his capacity as a judge were thus not an accurate reflection of his beliefs regarding legal (in)determinacy.

The following sections on linguistic indeterminacy, indeterminacy arising from the composition of valid norms, and the structural indeterminacy thesis all focus on jurists who were convinced that there are at least some indeterminacies in law. The real point of contention among these scholars is whether (international) law is locally or globally indeterminate. Moreover, it is contested whether legal indeterminacy stems from features of language (II.A.2), from legal interpretation and fact-ascertainment (II.A.3), or from structural contradictions (II.A.4). Jan Klabbers summarises the current discussion succinctly: '[r]ules tend to be open-ended and open-textured; the main point of debate amongst lawyers and philosophers alike revolves not around whether this is so (all agree), but the extent to which this is so.' 67

Since scholars like Kelsen, Llewellyn, and Frank have done their work, it is no longer necessary to show that legal decisions are not arrived at through a mechanical, almost automatic application of the law by way of logical reasoning. Criticising such a position today would amount to 'flogging a dead horse'. ${ }^{68}$ Almost no space in this study will therefore be dedicated to the

\footnotetext{
64 FITZMAURICE, 'Legal Advisers and Foreign Affairs', 82-83.

65 FITZMAURICE, 'The Law and Procedure of the International Court of Justice', 208.

66 GERALD FITZMAURICE, 'Judicial Innovation-Its Uses and Its Perils-As Exemplified in Some of the Work of the ICJ During Lord McNair's Period of Office', Cambridge Essays in International Law: Essays in Honour of Lord McNair (Stevens \& Sons 1965) 26.

67 JAN KLABBERS, ‘The Meaning of Rules’ (2006) 20 International Relations 295, 298.

68 KOSKENNIEMI, From Apology to Utopia, 36.
} 
examination of views nobody defends today. ${ }^{69}$ Instead, the focus will be on the questions of whether international law is indeterminate merely in some or in all cases and where such indeterminacies stem from. The following section will deal with views focusing on the indeterminacy that law shares with language.

\section{II.A.2 Linguistic Indeterminacy}

Linguistic indeterminacy may lead to legal indeterminacy. Conversely, the determinacy of language does not necessarily mean that the law is determinate, given that there may be reasons specific to law that diminish the extent of legal determinacy-such as the existence of contradictory but equally applicable methods of legal interpretation. The present section is solely concerned with the extent of determinacy that law shares with language.

Linguistic indeterminacy is often illustrated by the metaphor popularised by Hart ${ }^{70}$ of a stable core and a penumbra of uncertainty surrounding words:

If we are to communicate with each other at all, and if, as in the most elementary form of law, we are to express our intentions that a certain type of behaviour be regulated by rules, then the general words we use (...) must have some standard instance in which no doubts are felt about its application. There must be a core of settled meaning, but there will be, as well, a penumbra of debatable cases in which words are neither obviously applicable nor obviously ruled out. ${ }^{71}$

The classical example given by Hart is the rule prohibiting vehicles from entering a park. While a car would clearly be prohibited, the question of whether bicycles or roller skates would qualify as vehicles for the purpose of the rule would be a penumbral case. 72

The idea of rules being able to partly determine their application is captured by Hans Kelsen's metaphor of legal norms as frames. Like Hart, he recognised that vagueness and ambiguity in language can only be reduced to

69 The only exception being a concise discussion of the jurisprudence that the American legal realists attacked. See Sub-Section II.A.3.i.

70 Already in 1921, BENJAMIN CARDOZO used the metaphor of 'the borderland, the penumbra, where controversy begins'. BENJAMIN N CARDOZO, The Nature of the Judicial Process (Yale University Press 1921) 130; ENDICOTT, Vagueness in Law, 8.

$71 \quad$ HART, 'Positivism and the Separation of Law and Morals', 607.

72 HART, The Concept of Law, 126. 
a certain extent. ${ }^{73}$ Despite trying to develop a 'pure science' of law, Kelsen acknowledged the importance of non-legal considerations in the application of legal norms. To free legal science from political influences, Kelsen separated it from law-application, which he considered to be a creative and political process. His statement that legal theory is free from all value judgements, therefore, refers to law-ascertainment but does not say anything about his conception of the determinacy of law-application. ${ }^{74}$ Whether these are two distinct steps that can meaningfully be separated will be discussed in Section II.B.3.

The application of law, according to Kelsen, is everything but pure. He rejected the 'prejudice' that law is already contained in a general norm and only needs to be discovered. ${ }^{75}$ Instead, a hierarchically higher norm can only partially determine the application of a lower norm. It functions as a frame that limits the possible choices but does not fully determine them. Within the frame, the law-applier has full discretion. Positive law does not determine which decision ought to be taken within the frame. The frame can be broader or narrower, but it always remains a frame, never becomes a single point. ${ }^{76}$

Kelsen gives the example of a norm of criminal law that states '[i]f somebody steals something the value of which exceeds $\$ 1,000$, he shall be imprisoned for two years. ${ }^{77}$ A judge applying this law has to determine, for instance, the place and the starting date of the imprisonment. Kelsen thus argued that [h] owever detailed the general norm attempts to be, the individual norm created by the judicial decision will always add something new (...) The individualization of a general norm by a judicial decision is always a determination of elements which are not yet determined by the general norm and which cannot be completely determined by it. ${ }^{78}$

73 '(...) in view of the nature of the material utilized, i.e. human language, one can only obtain an approximation to the ideal of perfect clarity.' HANS KELSEN, Legal Technique in International Law: A Textual Critique of the League Covenant (Geneva Research Centre 1939) 17 (footnotes omitted).

$74 \quad$ KELSEN, Reine Rechtslehre: Einleitung in dierechtswissenschaftliche Problematik(Deuticke 1934) 61; JENS OLESEN wrongly accuses KELSEN and HART of naively believing in the apolitical nature of interpretation when he cites them for the following proposition '(...) we note that legal interpreters do not normally consider textual interpretation as a political act, but rather as a neutral tool with which the meaning of texts can be unlocked.' This is incorrect in HART's case and even more so for KELSEN, who explicitly discussed the political-subjective nature of legal interpretation. One should thus not transfer KELSEN's pure theory from law-ascertainment to legal interpretation. JENS OLESEN, 'Towards a Politics of Hermeneutics' in Andrea Bianchi, Daniel Peat, and Matthew Windsor (eds), Interpretation in International Law (Oxford University Press 2015) 311-312.

$75 \quad$ KELSEN, Reine Rechtslehre, 79, 99; HANS KELSEN, General Theory of Law \& State (first published 1949, Transaction 2006) 135.

$76 \quad$ KELSEN, Reine Rechtslehre, 91-97.

77 KELSEN, General Theory of Law \& State, 146

78 Ibid (emphasis added). 
The application of this norm gives rises to several questions. The question 'should, according to this norm of criminal law, someone who has stolen an object worth $\$ 2,000$ be imprisoned?' is determinate as the answer is clearly affirmative. The question 'to which prison should he or she be sent?' is indeterminate because it is within the discretion of the judge to send him to prison A, $\mathrm{B}$, or $\mathrm{C}$. The same legal question thus contains sub-questions, some of which are determinate and some of which are indeterminate.

In the above example, one might argue that the court's discretion in deciding when the imprisonment should start and where it takes place only concerns marginal questions of minor importance. Kelsen was not of the opinion, however, that there is such scope for choice only at the unimportant margins of the decision. He held instead that in most cases the central point of the decision could be diametrically opposed with equally good reasons: 'there is almost always a possible interpretation different from that adopted by the law-applying organ in a concrete case'. This, according to Kelsen, is evidenced by the existence of dissenting opinions attached to the majority decisions at the PCIJ and ICJ. ${ }^{79}$ Given that these dissenting opinions do not only deal with insignificant questions but often pertain to the central legal issue, it becomes evident that Kelsen's conception of indeterminacy is not limited to minor points such as the determination of the place of imprisonment.

It seems that the two quotes from Kelsen mentioned above are not aligned: 'judicial decisions will always add something new' 80 and 'there is almost always a possible interpretation different from that adopted by the law-applying organ in a concrete case'. ${ }^{81}$ However, the tension between these statements is only superficial. In Kelsen's view, there is indeed always a creative element in the application of law, but only regarding marginal issues, such as the decision whether a convict will be sent to one or the other prison. In contrast, differences regarding major legal issues, such as those often tackled in dissenting opinions of PCIJ and ICJ judges, only occur in almost all cases. Kelsen thus defended a conception of global indeterminacy when it comes to minor legal issues such as the place and starting date of imprisonment. More importantly, he argued for a view of local indeterminacy regarding central legal issues. Given that there is almost always a different possible interpretation even regarding central legal issues, Kelsen's account of local indeterminacy comes close to a conception of global indeterminacy.

79 HANS KELSEN, The Law of the United Nations: A Critical Analysis of Its Fundamental Problems (Stevens \& Sons 1951) xiv (emphasis added); KELSEN, Legal Technique in International Law, 14-15.

80 KELSEN, General Theory of Law \& State, 146 (emphasis added).

81 KELSEN, The Law of the United Nations, xiv (emphasis added). 
Both Hart and Kelsen agree that legal norms are determinate within their 'core' or at the boundaries of the 'frame'. They are indeterminate in the 'penumbra' or 'within the frame'. ${ }^{82}$ Hence both hold a conception of local linguistic indeterminacy. ${ }^{83}$ Koskenniemi challenges the Hartian and Kelsenian idea that judges have discretion only in 'hard cases'. He argues that such an approach necessitates a rule that can provide a clear distinction between law and discretion without allowing for any discretion itself. 'Easy cases' (such as someone in a car driving into a park) need to be clearly distinguished from 'hard cases' (such as someone on a bicycle entering a park) by a determinate rule. Given that there is no such rule, we cannot, so the argument goes, distinguish between law and discretion or between 'easy' and 'hard' cases. Hence legal uncertainty exists even in seemingly 'easy cases' ${ }^{84}$ I submit that Koskenniemi is right that there is no determinate rule that can separate 'easy' from 'hard' cases but that this does not prove that there cannot be 'easy cases'.

My argument can be illustrated by imagining a sand beach. Everyone would agree that zero grains of sand are not a beach, and nobody would argue that the innumerable grains of sand at Copacabana in Rio de Janeiro are not a sand beach. In other words, the questions 'are zero grains of sand a beach?' and 'is there a sand beach in Rio de Janeiro?' are 'easy cases'. The answer to the former is clearly 'no' while the answer to the latter is clearly 'yes'. If we took one grain of sand away from the Copacabana, it would still be a sand beach. Our answer would remain the same if we took two grains of sand away, etc. At some point, we would end up with zero grains of sand without having been able to determine the exact point at which the Copacabana ceased to be a sand beach. Koskenniemi is right that we cannot sharply distinguish when vague expressions are correctly applied and when incorrectly. If we tried to come up with a rule distinguishing sand beaches from heaps of sand, rationality from irrationality, vehicles from non-vehicles, or human rights from other rights, we would necessarily have to do so by using language. Given that all linguistic expressions are vague to some extent, this explanatory rule would itself be vague.

Koskenniemi's conclusion that because of the impossibility of coming up with a rule that precisely delineates the borders of vague concepts, we cannot

82 For a comparison and critique of HART's and KELSEN's conceptions of (in)determinacy, see DUNCAN KENNEDY, 'A Left Phenomenological Critique of the Hart/Kelsen Theory of Legal Interpretation' (2007) 40 Kritische Justiz 296, 297.

83 On the discussion about whether KELSEN's indeterminacy claim is based on linguistic indeterminacy, see ENDICOTT, Vagueness in Law, 61. I side with ENDICOTT, who holds that KELSEN's discussion of ambiguity implies that his conception of indeterminacy includes a doctrine of linguistic indeterminacy.

84 KosKenNIEMI, From Apology to Utopia, 44. 
meaningfully make use of such concepts at all goes too far. That we cannot precisely define vague expressions like 'sand beach' does not mean that there are no clear cases of what to call a 'sand beach'. Correspondingly, we cannot conclude that there are no 'easy cases' in law simply because we cannot define exactly when an 'easy case' becomes a 'hard case'. In other words, our inability to precisely define in which cases international law is determinate does not mean that there are no cases in which it clearly is determinate. Koskenniemi thus overestimates the importance of a precise rule that can sharply distinguish between 'easy' and 'hard' cases. ${ }^{85}$ Even though we cannot find such a rule, there are core cases in which an expression clearly applies.

Depending on the linguistic expression, the area of the core of settled meaning can vary in size. While words such as 'reasonable', 'fair', or 'just' obviously leave open a large area of discretion, it is not only such evaluative statements that exhibit local linguistic indeterminacy. All words have a penumbral area, even those that have a large and stable core; is a bicycle a vehicle? Is a beanbag a chair? How many grains of sand are enough to constitute a beach? Vehicles, chairs, and beaches are words that have a stable core of meaning, yet there are borderline cases. However, at first sight, there seem to be linguistic expressions that have no penumbra of uncertainty at all, such as 'ten' or 'at 3 o'clock'.

Semantically, 'at 3 o'clock' is indeed precise. It means at 3:00:00, and signifies neither at 2:59:59 nor at 3:00:01. If I ask you to come to my office 'at 3 o'clock', I do not ask you, however, to be there exactly at 3:00:00. Instead, it may be perfectly fine if you arrive two minutes later. Pragmatically speaking, knocking on my door at 3:02 still complies with my request. Depending on convention, it may even be appropriate to only show up at 3:15. We could thus say that ' 3 o'clock' is semantically precise but pragmatically vague. The meaning of the expression is precise, but the way people use it is not. However, for the purposes of the present study, the usefulness of distinguishing between semantics and pragmatics should be questioned. This becomes clear with expressions such as 'valuable' or 'useful', which can only be understood pragmatically. To isolate the semantic 'truth' of such words is impossible. What we consider valuable or useful always depends on the context. An academic article may be useful by providing ideas for one's research, but it may also be useful for starting a fire. In the former case, usefulness is primarily defined by the qualities of the ideas expressed in the article, while in the latter case, it

85 It should be noted that KOSKENNIEMI's critique of the distinction between 'hard' and 'easy' cases is not the only reason he puts forward to demonstrate that there are no 'easy cases'. His well-known structural indeterminacy thesis rests on an entirely different argument, which will be examined in Sections II.A.4 and II.B.2. 
mainly depends on whether the paper is inflammable.86 Of course, we can say that something is 'useful' in general when it 'helps someone achieve a goal', but this does not help us understand whether something is useful in a particular case. We can only know this once we have learned about the context. In order to answer whether an expression is correctly applied to a set of facts, we have to understand it pragmatically, not semantically. This is clearly the case for words such as 'useful', but it applies to any expression, including 'at 3 o'clock'. Hence even expressions like 'at 3 o'clock', despite their apparent preciseness, are surrounded by a penumbra of uncertainty if we understand them pragmatically (and we should understand them pragmatically). In Part II.B, I will elaborate on the argument why we should comprehend the extent of legal determinacy as a function of pragmatics rather than semantics.

So far, the discussion has centred around the irreducible vagueness that law shares with language. On top of this, vague and ambiguous terms may be chosen deliberately by the law-maker. Hart mentioned that if the legislature cannot usefully formulate uniform rules because individual cases are likely to vary considerably, a significant degree of discretion will be left open for the law-applier by employing terms such as 'fair' or 'safe'. In such cases, the core of settled meaning is rather small and the penumbra of uncertainty wide. While this does not mean that anything goes (there is still a core of settled meaning, even though it is tiny), it would be misguided to treat such questions as if there were one single correct answer since the question is likely to be decided within the penumbra where the law-applier enjoys discretion. ${ }^{87}$

In international contexts, vague and ambiguous terms are often the result of difficult negotiations. Detlev Vagts observed that open-textured treaty provisions are frequently 'designed to postpone insoluble problems' ${ }^{88}$ while Philipp Allot held that a treaty is 'a disagreement reduced to writing'. ${ }^{9}$ The fact that international treaties often contain vague and ambiguous formulations is obvious, and nobody would contest it. What is contested, however, is whether words have a stable core of settled meaning. Some legal theorists seem to claim that words are indeterminate not only at the margins but in their core. In what follows, I will show that even though some scholars may appear to be making such a global linguistic indeterminacy claim, nobody actually does. The main reason for this gap is most likely that such a claim would be

\footnotetext{
$86 \quad$ ENDICOTT, Vagueness in Law, 50-54.

87 HART, The Concept of Law, 131-132.

88 DETLEV F VAGTS, 'Treaty Interpretation and the New American Ways of Law Reading' (1993) 4 European Journal of International Law 472, 476.

89 PHILIP ALLOTT, 'The Concept of International Law' (1999) 10 European Journal of International Law 31, 43.
} 
self-defeating; an assertion that 'all statements are devoid of meaning, including the one I am currently making' could hardly be defended. ${ }^{90}$

Deconstructionists, at first sight, seem to claim that texts, including legal texts, are globally indeterminate. Jacques Derrida argued that '[e]ach case is other, each decision is different and requires an absolutely unique interpretation, which no existing, coded rule can or ought to guarantee absolutely.'91 Michel Rosenfeld observes that '(...) inasmuch as present writings are opaque, paradoxically, the meaning of a text could possibly be anything except that which it presently appears to be. ${ }^{92}$ David Gray Carlson holds that '[i]f I may write under erasure, the so-called radical indeterminacy thesis is clearly correct. ${ }^{93}$ On the face of it, the linguistic indeterminacy claims made by deconstructionists seem extreme: words do not have any meaning whatsoever. Nevertheless, nobody is willing to say that anything goes. ${ }^{94}$ Instead, deconstructionists hasten to add that texts may be indeterminate in the abstract but have meaning in a given context: '(...) the language of the summons is indeterminate on a number of levels, but that does not mean that it lacks meaning. (...) Words in context, like the context of a summons, are not malleable putty that can mean anything we desire. ${ }^{95}$ Seemingly provocative global linguistic indeterminacy theses by deconstructionists turn out to be much less radical than they first appeared when their authors conclude with statements such as: '[m]eaning, however, is neither subjective nor objective, but intersubjective.' In a similar vein, after endorsing a global indeterminacy thesis, Carlson concludes that

(...) language is simultaneously radically indeterminate and highly predictable. This is the distinction between logical and institutional meaning. Words may not logically contain the constraint of their own use, but you can often predict the effects word have on people. This is because, by convention, people learn to edit out context in predictable ways. It is

\footnotetext{
90 ENDICOTT, Vagueness in Law, 10, 14-17.

91 JACQUES DERRIDA, 'Force of Law: The "Mystical Foundation of Authority”' in Drucilla Cornell, Michel Rosenfeld, and David G Carlson (eds), Deconstruction and the Possibility of Justice (Routledge 1992) 21.

92 MICHEL ROSENFELD, 'Deconstruction and Legal Interpretation: Conflict, Indeterminacy and the Temptations of the New Legal Formalism' in Drucilla Cornell, Michel Rosenfeld, and David G Carlson (eds), Deconstruction and the Possibility of Justice (Routledge 1992) 158.

93 DAVID G CARLSON, 'Liberal Philosophy's Troubled Relation to the Rule of Law' (1993) 43 The University of Toronto Law Journal 257, 282.

94 ENDICOTT, Vagueness in Law, 16.

95 CHARLES M YABLON, 'Forms' in Drucilla Cornell, Michel Rosenfeld, and David GCarlson (eds), Deconstruction and the Possibility of Justice (Routledge 1992) 262.
} 
this very predictability that makes H.L.A. Hart's 'core meaning' assertion plausible to our experience (even as it fails to have philosophical plausibility). ${ }^{96}$

Despite appearances to the contrary, not even deconstructionists endorse a global linguistic indeterminacy claim. Instead, their seemingly radical ideas turn out to be the much less controversial proposition that meaning does not slumber within words but is a product of convention. While this insight is valuable, it is not nearly as radical as deconstructionist theories appear at first sight. In Sections II.B.1 and II.B.3, I will address how (legal) meanings are produced in practice. For the purpose of the present section, it suffices to note that even the seemingly most radical theorists, in the end, seem to agree with Hart that there is a core of settled meaning, even if they explicitly claim the contrary. ${ }^{97}$ Carlson's above-mentioned criticism of Hart's notion of 'core meaning' is, for instance, based on a misunderstanding. Hart did not argue that words have a stable, i.e. unchangeable and acontextual, core of meaning. Instead, his conception of the extent of legal determinacy occupies a middle ground between legal realism and what he called 'formalism'. Hart criticised the latter for attempting to 'freeze the same meaning in every case where its application is in question'98 and thus for pretending that legal concepts can have the same meaning in all contexts. ${ }^{99}$ Carlson's criticism of Hart's 'core meaning' is thus aiming at a straw man. Instead of providing a radical alternative to Hart's common wisdom, deconstructionists like Carlson-despite utterances to the contrary-agree that, in a given context, words have a stable core of meaning.

Deconstructionists and others who make the point that words have no meaning in the abstract may sometimes criticise straw men, but at other times their critique has a point. Aharon Barak, for instance, states that '[w]ords $d o$ have meaning. A cigarette is not an elephant.' 100 So far, so good. However, he adds: 'I decide cases by extracting meaning from its text.' 101 Such views, even though they do not represent the majority opinion today, are occasionally voiced: in a commentary on the VCLT, for instance, the authors write that

96 CARLSON, 'Liberal Philosophy's Troubled Relation to the Rule of Law', 283-284 (footnotes omitted).

97 Ibid; ENDICOTT, Vagueness in Law, 29.

98 HART, The Concept of Law, 129.

99 Ibid 130.

100 AHARON BARAK, 'Hermeneutics and Constitutional Interpretation’ (1992) 14 Cardozo Law Review 767, 767 .

101 Ibid (emphasis added). 
interpretation is about 'releasing the exact meaning and the content of the rule of law that is applicable to a given situation'.102 In such instances, the deconstructionists' critique has some force. If words are indeterminate in the abstract but only get meaning in a particular context, it is odd to use formulations that imply that meanings can be discovered in or extracted from legal texts. Instead, meanings can only be conferred on a text.

This view is increasingly held by scholars of international law. Koskenniemi writes that ' $[t]$ he interpretative techniques lawyers use to proceed from a text or a behaviour to its "meaning" create (and do not "reflect") those meanings.' 103 Similarly, Mattias Herdegen holds that '[i]nterpretation in international law essentially refers to the process of assigning meaning to texts and other statements for the purposes of establishing rights, obligations, and other consequences relevant in a legal context.'104 In the same vein, Isabelle Van Damme observes that ' $[\mathrm{t}]$ reaty text is language requiring meaning to apply it to the concrete facts with which the adjudicator is presented. The process of coming to this meaning is interpretation. '105 Finally, Richard Gardiner understands 'treaty interpretation (...) not as a quest for the original meaning of a statement or text, nor for simply taking words at their face value', ${ }^{106}$ but as a process which attributes meanings to texts and statements. ${ }^{107}$

If meanings are conferred on a text by the interpreter, this does not necessarily mean that the interpreter's individual views are the determining force. Instead, the meanings of texts are a function of the background conventions of interpretive communities. ${ }^{108}$ Given that the concept of interpretive

102 JEAN-MARC SOREL and VALÉRIE BORÉ-EVENO, 'Article 31' in Olivier Corten and Pierre Klein (eds), The Vienna Conventions on the Law of Treaties: A Commentary (Oxford University Press 2011) 806. See also JULIEN FOURET, PATRICK DAILLIER, and ALAIN PELLET, Droit international public (7th edn, LGDJ 2002), 253; INGO VENZKE submits that such views only rarely resurface these days as they have already been criticised since the negotiation process of the VCLT. INGO VENZKE, 'Sources in Interpretation Theories: The International Law-Making Process' in Samantha Besson and Jean d'Aspremont (eds), The Oxford Handbook of the Sources of International Law (Oxford University Press 2017) 404.

103 KOSKENNIEMI, From Apology to Utopia, 597.

104 MATTIAS HERDEGEN, 'Interpretation in International Law' in Rüdiger Wolfrum (ed), MaxPlanck Encyclopedia of Public International Law, online edition (Oxford University Press 2013), para 1 (emphasis added).

105 ISABELLE VAN DAMME, Treaty Interpretation by the WTO Appellate Body (Oxford University Press 2009) 33 .

106 RICHARD GARDINER, Treaty Interpretation (Oxford University Press 2008) 26.

107 Ibid 26-38.

108 The concept of interpretive communities is increasingly taken up in international legal scholarship. VERONICA FIKFAK and BENEDICT BURNETT, 'Domestic Courts' Reading of 
communities is not only useful for understanding how linguistic indeterminacy arises and is kept within bounds but crucial for comprehending how other kinds of indeterminacies of law are addressed as well, it shall be discussed at length in Section II.B.1.

At this point, it suffices to note the broad consensus that words have a stable core of meaning and a penumbra of uncertainty. Nobody is willing to say that anything goes, that 'cigarette' means 'elephant'. Instead, theses claiming that language is globally indeterminate actually posit this to be the case only in the abstract, i.e. when detached from context. Even deconstructionists who hold the seemingly most radical views on the indeterminacy of language agree that words do have a settled core of meaning within a given context. The deconstructionist critique has a point against those who imply that meanings are contained within, and can be extracted from, texts. While occasionally the view that the meaning of texts can be discovered within them rather than being conferred on them still resurfaces, it is a notion in decline. Instead, it is increasingly recognised by scholars of international law that meanings are produced by interpreters. How this process takes place is the subject of Sections II.B.1 and II.B.3.

\section{II.A.3 Indeterminacy Arising from the Composition of Norms}

Legal indeterminacy does not only emanate from the vagueness of the language through which law is inevitably expressed but also stems from reasons specific to law. Recall that the class of legal reasons consists of three components: first, the sources of law; second, the methods of interpretation and legal reasoning; third, the ways of fact-ascertainment. ${ }^{109}$ In this section, only the second and the third component of the class of legal reasons will be dealt with, i.e. indeterminacy due to interpretation and fact-ascertainment. The first component, the question of what can be considered a legal source, will be the subject of the following Section II.A.4.

International Norms: A Semiotic Analysis' (2009) 22 International Journal for the Semiotics of Law 437, 444-448; ANDREA BIANCHI, 'Textual Interpretation and (International) Law Reading: the Myth of (In)determinacy and the Genealogy of Meaning' in Pieter H F Bekker, Rudolf Dolzer, and Michael Waibel (eds), Making Transnational Law Work in the Global Economy: Essays in Honour of Detlev Vagts (Cambridge University Press 2010); JEAN D'ASPREMONT, Formalism and the Sources of International Law: A Theory of the Ascertainment of Legal Rules (Oxford University Press 2011) 195-203; VENZKE, How Interpretation Makes International Law, 46-49; MICHAEL WAIBEL, 'Interpretive Communities in International Law' in Andrea Bianchi, Daniel Peat, and Matthew Windsor (eds), Interpretation in International Law (Oxford University Press 2015) 147-165.

109 On the class of legal reasons, see Section I.B.1. 
The present section does thus not deal with indeterminacy that may arise from uncertainty about what constitutes valid law. Instead, it deals with uncertainties arising from the composition of valid legal norms. If the question of legal validity is deferred, issues regarding interpretation and fact-ascertainment cover all other possible specific indeterminacy theses, i.e. those indeterminacy theses relating to reasons specific to law.

\section{II.A.3.i Indeterminacy Arising from Legal Interpretation}

One of the most famous indeterminacy claims is the one by the American legal realist Karl Llewellyn. He argued that law is indeterminate in almost all cases due to the existence of equally applicable but contradictory methods of interpretation. His critique should be understood against the background of the

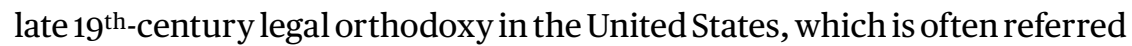
to as 'classical legal thought'. ${ }^{110}$ Because the two American legal realists Karl Llewellyn and Jerome Frank play an important role in this section, I shall briefly sketch the main ideas and challenges of their object of attack.

The core idea of classical legal thought was that society should be ruled by impartial and self-executing norms, by 'a government of laws, not of men'.111 A government of laws was possible, in the mind of most lawyers and judges, as they believed in the existence of clear boundaries of legal concepts that allow judges to apply the law without exercising discretion.112 Consequently, most jurists at the end of the $19^{\text {th }}$ century in the United States insisted that judges merely apply the law without making it. ${ }^{113}$ In the late $19^{\text {th }}$ century, efforts were made to create a self-contained system of legal reasoning that is autonomous from political considerations. ${ }^{114} \mathrm{As}$ an approximation, such an approach can be labelled 'formalistic' or 'conceptualistic'. By relying on logic, deduction from general principles, and analogical reasoning, formalists attempted to neatly distinguish the legal from the political.115 Christopher

110 MORTON J HORWITZ, The Transformation of American Law 1870-1960: The Crisis of Legal Orthodoxy (Oxford University Press 1994) 3.

111 Ibid 4.

112 HORWITZ points out that while most $19^{\text {th-century lawyers and judges believed in clear }}$ boundaries leading to legal determinacy, their position is all too easy to caricature. Most legal scholars believed in a 'core' and 'periphery' contained in legal categories. The goal of judges was to decide in a hard case (concerning a legal matter at the periphery of a category) whether it resembled the core of one category of cases more than that of another. Balancing tests that did not rely on such rigid categorisations increasingly appeared at the beginning of the $20^{\text {th }}$ century. Ibid 18 .

113 NATALIE E H HULL, Roscoe Pound and Karl Llewellyn: Searching for an American Jurisprudence (University of Chicago Press 1977) 34.

114 JUSTIN ZAREMBY, Legal Realism and American Law (Bloomsbury 2014) xv-xvi.

115 HORWITZ, The Transformation of American Law 1870-1960, 16. 
Langdell, dean of Harvard Law School from 1870 to 1895, believed that the analysis of precedent could lead to firm principles which, in turn, could be applied by judges to specific cases. 116 The implication of such a closed, unchanging legal system for lawyers was that they were merely supposed to reveal legal doctrines. The task of the lawyer was to read and understand judicial decisions, not to advance new arguments.117

The problem of formalism is that it renders it difficult to justify change. While significant socio-economic changes occurred in the United States at the turn of the $20^{\text {th }}$ century, ${ }^{118}$ formalism was not equipped to justify change in the court room. If the law does not allow for any discretion by judges, and with legislation lagging behind socio-economic developments, either cases will be decided without taking changed realities into account or judges will be forced to adapt the law to new situations while-consciously or unconsciously-hiding their law-making activities. The results are thus ill-adapted judicial decisions, judicial hypocrisy, or self-deception by judges. This situation contained the elements needed for a scientific paradigm shift as described by Thomas Kuhn: the old paradigm continues to be upheld, but its precepts are contradicted by an increasing amount of observations. 119

The formalistic reasoning of classical legal thought was the target American legal realists such as Llewellyn aimed at when formulating their critique. Llewellyn identified the primary source of indeterminacy in the methods of legal interpretation. He maintained that law is indeterminate due to the existence of conflicting, but equally correct, canons of interpretation. Llewellyn cited case-law of established American courts that relied on the following canons of interpretation: '[a] statute cannot go beyond its text.' However, '[t]o effect its purpose a statute may be implemented beyond its text.' ${ }^{120}$ Another example of impeccable, accepted, and contradictory canons of interpretation Llewellyn provided reads that '[i]f language is plain and unambiguous it must be given effect.' But '[n]ot when literal interpretation would lead to

116 PAUL D CARRINGTON, 'Hail! Langdell!' (1995) 20 Law \& Social Inquiry 691, 709; ZAREMBY, Legal Realism and American Law, xv-xvi; on the urge for clarity and certainty in the system of precedent in the late $19^{\text {th }}$ century in the United States, see KARL LLEWELLYN, 'On Philosophy in American Law' (1934) 82 University of Pennsylvania Law Reviewand American Law Register 205, 209.

117 ZAREMBY, Legal Realism and American Law, xvi.

118 MARIA A REA-FRAUCHIGER, Der amerikanische Rechtsrealismus: Karl N. Llewellyn, Jerome Frank, Underhill Moore (Duncker \& Humblot 2006) 14-20.

119 THOMAS S KUHN, The Structure of Scientific Revolutions ( $2^{\text {nd }}$ edn, University of Chicago Press 1970) 52-91; HULL, Roscoe Pound and Karl Llewellyn, 35.

120 KARL LLEWELlyn, 'Remarks on the Theory of Appellate Decision and the Rules and Canons about How Statutes are to be Construed' (1950) 3 Vanderbilt Law Review 395, 401. 
absurd or mischievous consequences or thwart manifest purpose.'121 Llewellyn bemoaned that even though two opposing canons of interpretation existed on almost every point, the idea that only one legally correct meaning can exist was still upheld among jurists in his time. ${ }^{122}$ However, '[i]n fact the available correct answers are two, three, or ten. The question is: Which of the available correct answers will the court select-and why? For since there is always more than one available correct answer, the court always has to select.' 123 Given that rules contained in statutes and case-law can be interpreted differently, there is more than one correct meaning of any precedent. Every precedent can be interpreted widely or narrowly according to need. ${ }^{124}$ Which meaning is respectable, traditionally sound, and dogmatically correct is determined by the choice made by the court, not through any objectively correct process of selection among the different readings. ${ }^{25}$ As judges have equally legitimate and recognised tools at their disposal to select and read precedents, the doctrine of precedent is Janus-faced. It is not one coherent doctrine but consists of contradictory precepts. ${ }^{126}$

While the most influential indeterminacy theses of the first half of the $2 \mathrm{O}^{\text {th }}$ century in the United States stemmed from the American legal realists and their leading figure Karl Llewellyn, Hans Kelsen's remarks about methods of interpretation and legal reasoning more generally had a similar impact in Europe. ${ }^{127}$ Recall that Kelsen's attempt to establish a pure science of law should not distract from his critical view on the interpretation of law. Because interpretation is not part of Kelsen's pure science of law, he did not feel compelled to prove the purity or objectivity of legal interpretation by establishing the existence of non-political methods. Quite to the contrary, he held that there is 'no such thing as a specifically juridical interpretation'. Nothing

\footnotetext{
121 Ibid 403.

122 Ibid 401; KARL N LLEWELLYN, 'Impressions of the Conference on Precedent' (1940) 14 University of Cincinnati Law Review 343, reprinted in KARL N LLEWELLYN, Jurisprudence: Realism in Theory and Practice (Transaction 2008) 123; KARL N LLEWELLYN, 'The Modern Approach to Counselling and Advocacy: Especially in Commercial Transactions' (1946) 46 Columbia Law Review 167, reprinted in LLEWELLYN, Jurisprudence, 338.

123 LLEWELLYN, 'Remarks on the Theory of Appellate Decision and the Rules and Canons about How Statutes are to be Construed', 396.

124 KARL N LLEWELLYN, The Bramble Bush: On Our Law and Its Study (first published 1930, Quid Pro 2012) 71; LLEWELLYN, 'Impressions of the Conference on Precedent', reprinted in LLEWELLYN, Jurisprudence, 123.

125 LLEWELLYN, The Bramble Bush, 69.

126 Ibid 68.

127 On the influence of KELSEN's critique, see KAMMERHOFER, 'Hans Kelsen in Today's International Legal Scholarship', 82.
} 
distinguishes legal interpretation from other sorts of intellectual activities that try to determine the significance of an object. ${ }^{128}$ Just as no interpretation only applies to legal norms, there is no method of interpretation particular to international law. No valid reasons, for instance, make a 'less rigid' or 'less literal' method more suitable for international law than for domestic law.129

Kelsen identified two main instruments of 'legal' interpretation, the historical and the logico-grammatical method. Legal scholars had, according to Kelsen, unsuccessfully attempted to resolve the conflict between the will of the legislator and the expression thereof in an objective way. ${ }^{130}$ No valid rule exists that establishes when to use which method. Since they may lead to divergent outcomes, a 'duality' of meaning is possible. ${ }^{131}$ The duality of possible meanings seems to imply that at least the historical and the logico-grammatical method in themselves lead to determinate outcomes. Otherwise there would be not only a duality but a multiplicity of possible meanings. In his analysis of the UN Charter, Kelsen indeed identified several interpretative approaches and held that ' $[t]$ he different methods of interpretation may establish different meanings of one and the same provision. Sometimes, even one and the same method, especially the so-called grammatical interpretation, leads to contradictory results.' 132 Moreover, Kelsen doubted whether anything like the will of the legislator even existed. Considering the complex procedures of law-making, Kelsen did not consider it possible to derive a determined outcome from such an exegesis. ${ }^{133}$

Reasoning per analogiam and a contrario are no help either in the determination of legal outcomes. Kelsen even called them 'utterly useless', given that they lead to opposite results while there is no criterion for when to use which one. ${ }^{134}$ Attempts to limit judicial discretion when applying legal norms per analogiam by claiming that a judge must adhere to the 'spirit of the law' are bound to fail. Such a spirit can only be determined by the subjective opinion of the judge. It is a fiction which conceals that judges create new law when

\begin{tabular}{ll}
\hline 128 & KELSEN, Legal Technique in International Law, 12. \\
\hline 129 & KELSEN referred to the British international lawyer Sir JOHN FISCHER WILLIAMS who \\
& had argued that 'the Covenant, more than any other document, must be construed \\
& according to the spirit, and as little as possible according to the letter.' JOHN FISCHER \\
& WILLIAMS, Some Aspects of the Covenant of the League of Nations (Oxford University \\
& Press 1934) 19; KELSEN, Legal Technique in International Law, 13. \\
\hline 130 & KELSEN, Reine Rechtslehre, 96. \\
\hline 131 & KELSEN, Legal Technique in International Law, 12. \\
\hline 132 & KELSEN, The Law of the United Nations, xiv. \\
\hline 133 & Ibid. \\
\hline 134 & KELSEN, Reine Rechtslehre, 96-97.
\end{tabular}


rendering a 'so-called analogical decision'.135 Neither is the concept of balancing of interests helpful. It is only a reformulation of the problem, as it does not provide an objective way of solving conflicts of interests. Balancing is based on political considerations, not on those that could be derived from a norm or even the entire legal system. If it were based on purely legal considerations, the need to decide which interest to prefer would not even arise. ${ }^{136}$

The reason why, according to Kelsen, the grammatical method is especially prone to lead to contradictory results is the already mentioned ambiguity inherent to language. While Kelsen was aware that language cannot be purified from ambiguity, he was convinced that many ambiguous formulations could be avoided. To help improve the precision of legal norms was a large part of his motivation for critically analysing the League Covenant and the UN Charter. 137

Like Kelsen, Myres McDougal was critical of the literal method of interpretation in international law. Frustrated by the outcome of the negotiations on methods of legal interpretation codified in the VCLT, McDougal attacked its strong focus on textuality. ${ }^{138}$ He accused the ILC's approach of coming close to Vattel's assumption that texts contain plain and natural meanings which do not need to be interpreted. ${ }^{139} \mathrm{McD}$ Dougal considered treating the text of an agreement as the exclusive index of the parties' expectations a 'primitive and potentially destructive formalism.' 140 Moreover, he rejected the idea that subjectivities could be read off by referring to the manifest content of words. ${ }^{141}$

135 HANS KELSEN, 'Law and Logic' in Ota Weinberger (ed), Essays in Legal and Moral Philosophy (Reidel 1973) 228, 248.

136 KELSEN, Reine Rechtslehre, 97.

137 KELSEN wrote: '[s] howing the legislator how far his product lags behind the goal of any law-making function, i.e. the unambiguous regulation of inter-individual or interstate relations, may induce him to improve his technique.' KELSEN, The Law of the United Nations, xvi; KELSEN, Legal Technique in International Law, 10, 16-17; BARDO FASSBENDER makes the point that the UN Charter would not have endured without the ambiguities and contradictions that KELSEN lamented. BARDO FASSBENDER, 'Friede durch Recht: Hans Kelsen und die Vereinten Nationen' in Hauke Brunkhorst and Rüdiger Voigt (eds), Rechts-Staat: Staat, internationale Gemeinschaft und Völkerrecht bei Hans Kelsen (Nomos 2008) 139.

138 MYRES S MCDOUGAL, 'The International Law Commission's Draft Articles upon Interpretation: Textuality Redivivus' (1967) 61 The American Journal of International Law 992.

139 Ibid 996.

140 Ibid 997.

141 Ibid 996; MCDOUGAL ascribed such a textual approach to legal positivists: '[t]he builtin assumptions are that verbal rules, as well as other communications, are capable of an independent non-contextual import; (...) These assumptions are of course a caricature of reality. Communications inquiry and contemporary linguistics have solidly established the integral relation of communication and context and the necessarily 
Instead of mainly relying on legal texts, a goal-oriented interpretation that focuses on the current genuine shared expectations of the parties is required. $\mathbf{1 4 2}^{2}$ If doubt arises about these expectations, the provision has to be interpreted in line with fundamental community policies. ${ }^{143}$

Another root of legal indeterminacy, according to McDougal, is that rules of international law are commonly formulated in complementary opposites and consist of few basic terms with highly variable reference. The rule of the non-use of force in international relations is, for instance, accompanied by the exception of self-defence. A non-arbitrary decision based solely on contradictory principles cannot be reached:

A judge who must choose between such principles can only offer as justification for his choice a proliferation of other such principles in infinite regress or else arbitrarily take a stand and state his preference; and what he prefers or what he regards as 'authoritative' is likely to be a product of his whole biography. ${ }^{144}$

Decision-makers are thus not faced with neat symmetrical dichotomies but with a spectrum of multiple choices. According to McDougal, policy choices need to determine where on the spectrum the most rational, creative, and

creative operation involved in the interpretation of any past communication.' MYRES S MCDOUGAL, HAROLD D LASSWELL, and W MICHAEL REISMAN, 'Theories about International Law: Prologue to a Configurative Jurisprudence’ (1968) 8 Virginia Journal of International Law 188, 245 (footnotes omitted).

142 MCDOUGAL, 'The International Law Commission's Draft Articles upon Interpretation', 997-998; MYRES S MCDOUGAL, HAROLD D LASSWELL, and JAMES C MILLER, The Interpretation of Agreements and World Public Order: Principles of Content and Procedure (Yale University Press 1967) 215. The overriding aim of such interpretations is to help establish a universal order of human dignity. MYRES S MCDOUGAL, 'The Identification and Appraisal of Diverse Systems of Public Order' (1959) 53 The American Journal of International Law 1-29, 11. Any inquiry about legal problems has to start with the explicit postulation of values of human dignity seen from the observational standpoint of the whole of humankind. MYRES S MCDOUGAL, HAROLD D LASSWELL, and LUNG-CHU CHEN, Human Rights and World Public Order: The Basic Policies of an International Law of Human Dignity (Yale University Press 1980) 367-368.

143 MYRES S MCDOUGAL and W MICHAEL REISMAN, International Law in Contemporary Perspective: The Public Order of the World Community-Cases and Materials (Foundation Press 1981) 1194. In case of competing claims, the decision-maker should 'make reference to the whole congeries of factors relevant in that context-and contexts vary greatly. (...) Fortunately, the complementary and highly ambiguous character of inherited, authoritative doctrine has made it possible for a decision-maker to take all these variables into account (...)'. MYRES S MCDOUGAL and WILLIAM T BURKE, The Public Order of the Oceans: A Contemporary International Law of the Sea (first published 1962, New Haven Press 1985) 57.

144 HAROLD D LASSWELL and MYRES S MCDOUGAL, 'Legal Education and Public Policy: Professional Training in the Public Interest' (1943) 52 Yale Law Journal 203, 236 (emphasis added). 
adaptive decision is to be made. This does not mean that legal rules have no potential for guiding decisions at all, but they clearly cannot mechanically dictate specific outcomes. Instead, the 'realistic function' of rules is to bring to the attention of the decision-maker the 'significant variable factors in typical recurring contexts of decision [and] to serve as summary indices to relevant crystallized community expectations'. ${ }^{145}$ Legal rules are just one among many factors that may guide decision-makers. Whether it is a legal rule or a policy that serves to clarify community expectations does not matter in McDougal's conception. This may feel irritating for international lawyers who are used to a clear distinction between law and politics, but it flows naturally from McDougal's wide conception of law. ${ }^{146}$

A decision-maker who unsuccessfully tries to determine an outcome with the help of conflicting legal rules may try to solve the problem by relying on previous cases. However, this will not help him escape the dilemma. If he keeps within the legal syntax, McDougal and Lasswell argued, he begs the very question he tries to answer. The two central figures of the New Haven School approvingly quoted the legal realist Herman Oliphant on this point:

If the principle (...) 'induced' is no broader than the sum of the previous cases which it summarizes, it obviously does not and cannot include the case to be decided, which, by hypothesis, is a new and an undecided case, and, hence, can form no part of the generalization made from previous cases only. If it does not include the case to be decided, it is powerless to produce and determine a decision of it. If it is taken to include the case to be decided, it assumes the very thing that is supposed to be up for decision. ${ }^{147}$

Hence treaty texts cannot be clarified by relying on other texts, on determining legal principles, or on case-law. McDougal and Lasswell were not the first ones to observe that the justification of a principle by another principle cannot solve the dilemma. Immanuel Kant already made the point that

(...) if [general logic] wanted to show generally how one ought to subsume under these rules, i.e., distinguish whether something stands under them or not, this could not happen except once again through a rule.

145 MYRES S MCDOUGAL and FLORENTINO P FELICIANO, Law and Minimum World Public Order: The Legal Regulation of International Coercion (Yale University Press 1961) 57.

146 According to MCDOUGAL, law is more than rules applied by officials but is best conceived as a 'flow of authoritative and controlling decisions'. MYRES S MCDOUGAL, 'Law as a Process of Decision: A Policy-Oriented Approach to Legal Study’ (1956) 1 Natural Law Forum 53, 65.

147 HERMAN OLIPHANT and ABRAHAM HEWITT, 'Introduction' in Jacques Rueff, From the Physical to the Social Sciences (Johns Hopkins Press 1929) xix. 
But just because this is a rule, it would demand another instruction for the power of judgment, and so it becomes clear that although the understanding is certainly capable of being instructed and equipped through rules, the power of judgment is a special talent that cannot be taught but only practiced. 148

The idea that rules (of interpretation) are themselves dependent on other rules was also expressed by Hart when he argued that

[c]anons of 'interpretation' cannot eliminate, though they can diminish, these uncertainties; for these canons are themselves general rules for the use of language, and make use of general terms which themselves require interpretation. They cannot any more than other rules provide for their own interpretation. ${ }^{149}$

More recently, Ingo Venzke made a similar observation when he argued that the attempt to clarify the meaning of a rule by another rule leads to an infinite regress. ${ }^{150}$

Some philosophers, legal theorists, and international lawyers have thus been aware for a long time that interpretive rules cannot by themselves clarify the meaning of other rules. A rule is clarified by a different rule, which is elucidated by a meta-rule, just like planet Earth is stabilised by a turtle which in turn stands on a another turtle-rules and turtles all the way down. Identifying an infinite regress is usually part of an objection to a theory: 151 because there cannot be 'turtles all the way down', the theory that planet Earth rests on an infinite tower of turtles has to be rejected. Interestingly, this does not seem to apply to interpretive legal methods. Even though e.g. Hart recognised that methods of interpretation lead to an infinite regress, he did not conclude that we should reject the idea that the meaning of legal rules can be clarified by interpretive rules. Instead, as seen above, Hart wrote that rules of interpretation can diminish the uncertainties arising in legal interpretation. ${ }^{152}$

Despite the infinite-regress critique raised against rules of interpretation, the use of interpretive methods in international law has not gone out of fashion. Quite to the contrary, "[t]he "state of play" is characterised by a myopic

148 Immanuel Kant, Critique of Pure Reason (first published 1781, Cambridge University Press 1998) 268.

149 HART, The Concept of Law, 126.

150 VENZKE, How Interpretation Makes International Law, 30.

151 ROSS CAMERON, 'Infinite Regress Arguments' (2018) The Stanford Encyclopedia of Philosophy.

152 HART, The Concept of Law, 126. 
focus on the rules of treaty interpretation in Articles 31-33 of the VCLT, and an aversion to the more theoretical dimensions of the subject.' 153 In responding to the New Haven School's approach about legal interpretation, Alexander Orakhelashvili even defended the view that ' $[t]$ he text of the Vienna Convention, the process of its drafting and the practice of its application are all unanimous in affirming that the rules of treaty interpretation are fixed rules and do not permit the interpreter a free choice among interpretative methods.' 154 While the dangers of uncritically using the VCLT's interpretive rules have been observed, 155 the prevalent position is that 'in all matters international, always interpret in accordance with the rules of the Vienna Convention.' 156

Every international lawyer today would agree that there are some uncertainties connected to the interpretation of international law. However, only few go as far as drawing any consequences from the deeper theoretical problem of the infinite regress of interpretive rules. Nevertheless, the latter problem seems to be a greater challenge, given that it fundamentally calls into question whether the meaning of rules can ultimately be clarified by other rules. If methods of legal interpretation conflict and we are unable to establish any hierarchy among them, the result is local indeterminacy in those cases that are affected by such clashes. If no convincing answer to the infinite-regress challenge can be found, however, the result is global indeterminacy, given that every legal case (even a straightforward one) involves interpretation. In Sections II.B.1 and II.B.3, I will discuss when a clash of interpretive methods and the infinite-regress challenge may result in legal indeterminacy.

\section{II.A.3.ii Indeterminacy Arising from Fact-Ascertainment}

Indeterminacy may arise due to uncertainties regarding fact-ascertainment. 'Fact-ascertainment' for the purpose of this section should be understood broadly. It ranges from the process of establishing the facts in a judicial procedure to the perception and selection of phenomena that are said to exist and are considered to be relevant for a legal doctrine or for any (expert) opinion.

\footnotetext{
153 DANIEL PEAT and MATTHEW WINDSOR, 'Playing the Game of Interpretation: On Meaning and Metaphor in International Law' in Andrea Bianchi, Daniel Peat, and Matthew Windsor (eds), Interpretation in International Law (Oxford University Press 2015) 4 (footnote omitted).

154 ALEXANDER ORAKHELASHVILI, The Interpretation of Acts and Rules (Oxford University Press 2008) 309.

155 JAMES CRAWFORD, Brownlie's Principles of Public International Law (8th edn, Oxford University Press 2012) 380; PEAT and WINDSOR, 'Playing the Game of Interpretation', 5 .

156 JAN KLABBERS, 'Virtuous Interpretation' in Malgosia Fitzmaurice, Olufemi Elias, and Panos Merkouris (eds), Treaty Interpretation and the Vienna Convention on the Law of Treaties: 30 Years On (Martinus Nijhoff 2010) 24.
} 
The legal realist Jerome Frank forcefully put forward an indeterminacy thesis based on uncertainties surrounding fact-ascertainment. As he is considered the leading 'fact-sceptic' among the American legal realists, ${ }^{157}$ his views are a suitable starting point for the discussion, even though they refer to domestic law. As will be argued below, there is no qualitative but only a quantitative difference between domestic and international law when it comes to indeterminacy arising from fact-ascertainment.

According to Frank, the classification of facts as legally relevant is based on two sets of elusive factors: first, the way witnesses portray the facts, and second, the reaction of the judge. Witnesses' testimonies are fallible, given that they might lie, they might not have observed the events correctly, they may not remember their observations accurately, or they may wrongly communicate those memories in the courtroom. ${ }^{158}$ More importantly, judges are fallible in guessing whether the witnesses portrayed the facts accurately. Furthermore, as human beings, judges may have biases that are unknown not only to the parties but often even to themselves. These biases are peculiar to each individual judge and thus cannot be formulated as uniformities.

Given that no rules can govern the discretion of judges in classifying facts as legally relevant, trial court judges have an 'almost uncontrollable "fact discretion"'. ${ }^{159}$ As fact-'finding' is mostly done by trial courts, the fact sceptics such as Frank advocated concentrating more on trial courts instead of upper courts. ${ }^{160}$ They considered trial courts the most important element of the administration of justice, given that upper courts are dependent on facts that were 'found' at the first instance. ${ }^{161}$ Frank thus accused the rule-sceptics, such as Karl Llewellyn, of cold-shouldering trial courts while not even informing their readers that their focus is mainly on upper courts. ${ }^{162}$

Like Frank, Llewellyn identified uncertainties relating to fact-'finding' as a source of indeterminacy. He challenged the idea that logical reasoning can lead to a determined conclusion when selecting and assessing the evidence.

157 JULIUS PAUL, The Legal Realism of Jerome N. Frank: A Study of Fact-Skepticism and the Judicial Process (Martinus Nijhoff 1959) 81-91; BRIAN LEITER even wrote of a 'Frankification' regarding the strong influence of JEROME FRANK on the perception of legal realism. BRIAN LEITER, NaturalizingJurisprudence, 17.

158 JEROME N FRANK, “Short of Sickness and Death”: A Study of Moral Responsibility in Legal Criticism' (1951) 26 New York University Law Review 545, 547; JEROME N FRANK, 'Both Ends Against the Middle' (1951) 100 University of Pennsylvania Law Review 20, 23.

\begin{tabular}{ll}
\hline 159 & FRANK, 'Both Ends Against the Middle', 23. \\
\hline 160 & Ibid; FRANK, Law and the Modern Mind, xxiii. \\
\hline 161 & JEROME N FRANK, 'Judicial Fact-Finding and Psychology' (1953) 14 Ohio State Law Jour- \\
& nal, 183, 183; on the importance of trial courts, see also FRANK, 'Words and Music', 1278. \\
\hline 162 & FRANK, Law and the Modern Mind, xxiii.
\end{tabular}


Instead, he maintained that making a choice is unavoidable when selecting the evidence, interpreting it, and classifying it as legally relevant. ${ }^{163}$ Llewellyn's advice to litigators on how to win a case was to portray the facts in a favourable light, while finding the corresponding legal rules was of secondary importance. ${ }^{164}$ He maintained that one ought to bear in mind in appellate court decisions 'how far the proposition which seems so abstract has roots in what seems to be the due thing on the facts before the court.' 165 He thus agreed with Frank that 'fact-pressures of the cases' 166 play a major role in judicial decisions. ${ }^{167}$ While Llewellyn has been called a 'rule-sceptic', ${ }^{168}$ he was thus, to a lesser extent, a 'fact-sceptic' as well.

The same applies to Hans Kelsen. He harshly criticised naive notions of the usefulness of interpretive methods but also those of readily available facts: '[i]t is a typical layman's opinion that there are absolute, immediately evident facts. Only by being first ascertained through a legal procedure are facts brought into the sphere of law or do they, so to speak, come into existence within this sphere.' The organ ascertaining the legally relevant facts does not simply find but create them. Ascertaining facts, therefore, has a constitutive character. ${ }^{169}$ Hence Kelsen, too, was both a rule-sceptic and a fact-sceptic.

Like Kelsen, Hersch Lauterpacht argued that facts are not simply found but are created. In the context of the endless discussion about statehood, Lauterpacht criticised the declaratory view of recognition, which holds that a State exists under international law as soon as the conditions of statehood found in international law are fulfilled as a matter of fact:

Upon analysis, it seems unhelpful and tautologous to say that recognition is purely formal and declaratory for the reason that a State becomes a subject of international law as soon as it exists or that a State comes into

\footnotetext{
163 LLEWELLYN, The Bramble Bush, 72; LLEWELLYN, 'Remarks on the Theory of Appellate Decisions and the Rules or Canons about How Statutes are to be Construed', 395 .

164 LLEWELLYN, The Bramble Bush, 72; KARL N LLEWELLYN, 'A Lecture on Appellate Advocacy' (1962) 29 The University of Chicago Law Review 627, 639.

165 LLEWELLYN, The Bramble Bush, 36.

166 KARL N LLEWELLYN, 'Some Realism about Realism: Responding to Dean Pound' (1931) 44 Harvard Law Review 1222, 1243; KARL N LLEWELLYN, The Common Law Tradition: Deciding Appeals (Little, Brown \& Co 1960) 122.

167 LLEWELLYN, The Common Law Tradition, 397.

168 HART, The Concept of Law, 139; AJAY K MEHROTRA, 'Law and the "Other": KARL N. LLEWELLYN, Cultural Anthropology, and the Legacy of The Cheyenne Way' (2001) 26 Law \& Social Inquiry 741, 746; PAUL, The Legal Realism of Jerome N. Frank, 81.

169 KELSEN, General Theory of Law \& State, 136; see also KELSEN, Legal Technique in International Law, 12.
} 
being as soon as there exist the requirements of statehood. For such existence may be and often is the question at issue..$^{170}$

Koskenniemi expresses the critique of this approach, which he shares with Lauterpacht, as follows: '[a] realism according to which "facts" create law relies on an extreme naturalism that (...) fails to account for the process whereby facts are constructed in the act of cognition by the human mind.' 171

Given that facts cannot simply be found in the world but have to be selected and assessed, Koskenniemi argues, this creative process can only be understood from within a certain context of argument. What counts as a relevant fact and how much weight is ascribed to each fact is the product of a struggle within an argumentative community. ${ }^{172}$ This is the case not only in law but in all systems where facts have to be taken into account, i.e. where they have to be selected for their relevance and given a certain importance. Koskenniemi is thus highly sceptical of seemingly neutral experts who claim to solve a problem by relying on 'the facts'. Since expertise is no less indeterminate than the law it purports to clarify, the problem of uncertain knowledge is simply shifted from an interpretation of the law to an equally contested assessment of the facts. ${ }^{173}$

In international law, this idea has most prominently been defended by David Kennedy. Legal decisions are often taken with reference to some factual inevitability. ${ }^{174}$ The work of (legal) experts is thereby downplayed. ${ }^{175}$ It appears that nobody is deciding and that decisions are always taken elsewhere. Instead of deciding, experts claim to merely analyse the facts and draw seemingly inevitable conclusions from them. ${ }^{176}$ But the role of experts is crucial, as '[b]oth the assertion that something is the context, and the inter-

170 HERSCH LAUTERPACHT, Recognition in International Law (Cambridge University Press 1947) 45.

171 MARTTI KOSKENNIEMI, 'Hierarchy in International Law: A Sketch' (1997) 8 European Journal of International Law 566, 578; on the tension between the views of sovereignty either being a function of facts or of law, see MARTTI KOSKENNIEMI, 'The Politics of International Law' (1990) 1 European Journal of International Law 4, 16.

172 MARTTI KosKenNIEMI, 'Law, Teleology and International Relations: An Essay in Counterdisciplinarity' (2011) 26 International Relations 3, 20.

173 MARTTI KOSKENNIEMI, 'Constitutionalism as Mindset: Reflections on Kantian Themes about International Law and Globalization' (2007) 8 Theoretical Inquiries in Law 9, 30.

174 DAVID KENNEDY, 'The Turn to Interpretation' (1985) 58 Southern California Law Review 251, 256.

175 DAVID KENNEDY, ‘Challenging Expert Rule: The Politics of Global Governance’ (2005) 27 Sydney Law Review 1,5 .

176 DAVID KENNEDY, A World of Struggle: How Power, Law, and Expertise Shape Global Political Economy (Princeton University Press 2016) 3. 
pretation of its consequences are the acts of experts.' 177 By deploying their technical vocabularies, however, experts manage to hide their power and their politics. ${ }^{178}$

While these sceptical views are far from representing the majority opinion in international legal scholarship today, it is uncontested that facts cannot simply be ascertained but have to be weighed. ${ }^{179}$ Regarding expert advice given by scientists, the WTO Appellate Body held that ' (...) it is generally within the discretion of the Panel to decide which evidence it chooses to utilize in making findings. ' 180 Only a minority argues that judges should not weigh the expert knowledge externally acquired. ${ }^{181}$ This opinion, which is based on a belief in the determinacy of scientific knowledge, ${ }^{182}$ seems to belong to the past. The view, as expressed by d'Aspremont and Mbengue, that expert knowledge is as indeterminate as the law it purports to clarify is, however, not a majority opinion either. To their mind, there is no scientific truth but a struggle for persuasiveness and authority. Facts are not external to such a struggle and thus cannot be used to bring it to an end. ${ }^{183}$

It is most productive to analyse the indeterminacies arising from the ascertainment of customary international law as a challenge of fact-ascertainment. While this could also be done under the heading of 'sources', 184 the core of the problem relates to whether certain facts, i.e. physical and verbal acts by State representatives, amount to State practice and opiniojuris. The legal indeterminacies arising from such challenges have frequently been observed. 185

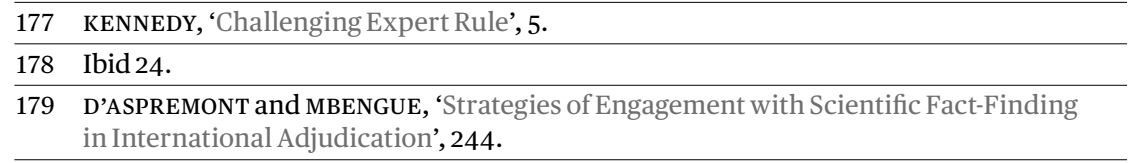

180 WTO Appellate Body, EC-Measures Concerning Meat and Meat Products (Hormones), 16January 1998, Appellate Body Report, WT/DS26/AB/R, para 135.

181 Manfred Lachs, for instance, argued that '[w]henever law is confronted with facts of nature or technology, its solutions must rely on criteria derived from them.' ICJ, North Sea Continental Shelf (Federal Republic of Germany v Denmark; Federal Republic of Germany v Netherlands), Judgement of 20 February 1969, Dissenting Opinion of Judge Lachs, ICJ Reports 219, 222; D’ASPREMONT and MBENGUE, 'Strategies of Engagement with Scientific Fact-Finding in International Adjudication', 264.

182 D'ASPREMONT and MBENGUE, 'Strategies of Engagement with Scientific Fact-Finding in International Adjudication', 264.

183 Ibid 263.

184 CAMERON A MiLES, 'Indeterminacy' in Jean d'Aspremont and Sahib Singh (eds), Concepts for International Law: Contributions to Disciplinary Thought (Edward Elgar 2019) 452.

185 In lieu of numerous references, ADIL A HAQUE, 'Indeterminacy in the Law of Armed Conflict' (2019) International Law Studies 118, 139; ARIEL ZEMACH, 'Indeterminacy in the Law of War: The Need for an International Advisory Regime' (2017) 43 Brooklyn Journal of International Law 1, 45-46. 
To what extent the difficulties surrounding customary international law lead to legal indeterminacy will be discussed in Sub-Section II.B.1.ii.b.

Theses that locate the roots of legal indeterminacy in fact-ascertainment were forcefully put forward by legal realists, and their influence is noticeable till today. At the very least, it does not seem possible anymore to believe in readily available facts that can provide answers to legal questions in an objectively correct way. This widespread scepticism, however, does not result in an anything-goes mentality. Just as in the case of linguistic indeterminacy, the claim is not that words or facts are devoid of meaning. Instead, it is merely asserted that facts do not contain meanings in the abstract but that, just like in the case of words, a particular community confers meaning on them. ${ }^{186}$ Within a given community, the degree of relevance of a fact, i.e. of a phenomenon in the world which is qualified as a 'fact', is crystal-clear most of the time. That facts only acquire meaning within a particular community does thus not mean that we can never be sure about their existence or how to interpret them. This also applies to the ascertainment of the facts needed to establish the existence of customary international law. I will come back to the process of conferring meaning on words and facts in Sections II.B.1 and II.B.3.

Both linguistic indeterminacy and legal indeterminacy stemming from interpretation and fact-ascertainment exist in domestic as well as in international law. There is no difference of kind, but only one of degree, between the extent of these types of indeterminacy in municipal and international legal systems. This argument will be made in greater detail in Sub-Section II.B.3.v. In the following section on the structural indeterminacy thesis, in contrast, I will deal with a claim that only seems to develop its full force on the international level. It is the most radical indeterminacy thesis in international law and also the most controversial one. While all modern jurists would agree that both domestic and international law are at least in some cases indeterminate for linguistic reasons or due to the challenges of interpretation and fact-ascertainment just outlined, ${ }^{187}$ only few would argue that international law is globally indeterminate due to structural shortcomings.

186 KOSKENNIEMI, for instance, argues that '(...) what count as relevant facts and how their importance should be assessed is determined from within the relevant context of argument, through the adversarial procedures that law provides for social agents. This is the truth of law as an institutional practice: its standards and performances are internally validated.' MARTTI KOSKENNIEMI, 'Law, Teleology and International Relations: An Essay in Counterdisciplinarity’, 20.

187 KLABBERS, 'The Meaning of Rules', 298. 


\section{II.A.4 At the Other End of the Spectrum: Indeterminacy of the Structure of International Law}

The most radical indeterminacy thesis in international law has been put forward by David Kennedy and Martti Koskenniemi. They argue that international law is not only indeterminate in cases where vague linguistic expressions are used or due to uncertainties arising in legal interpretation and factascertainment. ${ }^{188}$ Kennedy and Koskenniemi's well-known claim is not that valid international legal norms are indeterminate but that there cannot be any valid international law in the first place. Their main critique thus tackles a more fundamental issue than those indeterminacy theses that have been portrayed so far. In other words, the 'structural indeterminacy thesis' as put forward by Kennedy and Koskenniemi concerns the first class of legal reasons: the sources of law. This section thus treats the last remaining class of legal reasons following the treatment of the other two classes (interpretation and fact-ascertainment, as discussed in Section II.A.3). Neither Kennedy nor Koskenniemi would, however, frame their claim as pertaining to the sources of law and thus to legal validity. The reason is that they try to go beyond the classical controversy between legal positivists and natural lawyers about what can be considered a source of law. Instead, they understand international law as an argumentative practice.

\section{II.A.4.i International Law as an Argumentative Practice}

Kennedy and Koskenniemi's focus on legal rhetoric can be understood as an attempt to break out of a deadlocked situation. To them, it seemed useless to continue the unfruitful doctrinal transformations of what they consider the fundamental problems of (neo-)naturalism and (neo-)positivism. ${ }^{189}$ Kennedy and Koskenniemi do not put forward their own 'method' but propose a new 'style' for analysing international legal discourse. 190 The analysis of the structures of international legal argument, they hope, is to bridge the divide

188 The structural indeterminacy thesis has sometimes been wrongly portrayed as a claim about linguistic indeterminacy. E.g. BECKETT, 'Behind Relative Normativity: Rules and Process as Prerequisites of Law' 643-647; PAULUS, Die internationale Gemeinschaft im Völkerrecht, 211-217. KENNEDY and KOSKENNIEMI's structural indeterminacy thesis is, however, not based on any linguistic vagueness of legal speech. Even if linguistic expressions were not vague, international law would be globally indeterminate in their view. KOSKENNIEMI, From Apology to Utopia, 590.

189 DAVID KENNEDY, 'Theses about International Law Discourse’ (1980) 23 German Yearbook of International Law 354, 378-379.

190 Ibid 355, fn 4; MARTTI KOSKENNIEMI, 'Letter to the Editors of the Symposium' (1999) 93 The American Journal of International Law 351, 353. 
between theory and practice of international law. They try to do so by making the structures of argumentation visible which are contained both in theory and doctrine. ${ }^{191}$

Kennedy and Koskenniemi call their style 'structuralist', 'dialectical', and 'deconstructive'. It is 'structuralist' as it describes international law as a language and tries to explain the patterns of discourse as well as the interconnection between doctrines and conceptual schools. It can be labelled 'dialectical' because it focuses on the contradictions that exist in both theory and legal discourse. Finally, their style can be called 'deconstructive' as they show that these contradictions have manifested themselves in 'deep-structural' binary oppositions that depend on each other for their force. ${ }^{192}$ The most direct influences on Kennedy and Koskenniemi are scholars associated with the critical legal studies movement. Particularly strong inspiration stems from Roberto Unger's critique of liberalism and Duncan Kennedy's study of private law doctrine and its history. ${ }^{193}$ However, Koskenniemi argues that large parts of his work 'might seem an insult' to the original 'crits'. ${ }^{194}$

Kennedy and Koskenniemi do not portray their own 'style' as objectively better than other 'methods' used in international law. The reason is, as Koskenniemi explains, that methodological changes cannot be judged from a non-methodological standpoint. Instead, Methodenstreit takes place between closed systems that can only justify themselves by referring to their own conclusions. It is therefore not possible to compare the value of different methods from a neutral point of view. Scientific methods change because of shifting social and cultural conventions, not as the result of an objective comparison and evaluation of different methodological frameworks. Koskenniemi thus

191 KENNEDY, 'Theses about International Law Discourse', 354-355; KosKENNIEMI, From Apology to Utopia, 7 .

192 KENNEDY, ‘Theses about International Law Discourse', 355, fn 4; KOSKENNIEMI, 'Letter to the Editors of the Symposium', 355 .

193 ROBERTO M UNGER, Knowledge and Politics (Free Press 1975); DUNCAN KENNEDY, 'Form and Substance in Private Law Adjudication' (1976) 89 Harvard Law Review 1685-1778; DUNCAN KENNEDY, 'The Structure of Blackstone's Commentaries' (1979) 28 Buffalo Law Review 205-382; for a list of other intellectuals who influenced KOSKENNIEMI and KENNEDY, see DAVID KENNEDY, 'The Last Treatise: Project and Person (Reflections on MARTTI KOSKENNIEMI's “From Apology to Utopia”)' (2006) 7 German Law Journal 982, 984 .

194 KOSKENNIEMI, 'Letter to the Editors of the Symposium', 351; ALTWICKER and DIGGELMANN argue that the works of KENNEDY, KOSKENNIEMI, and other scholars associated with the so-called 'newstream' cannot be considered mere offshoots of critical legal studies. The indeterminacy thesis is, however, an idea that was significantly influenced by the 'crits'. TILMANN ALTWICKER and OLIVER DIGGELMANN, 'What Should Remain of the Critical Approaches to International Law? International Legal Theory as Critique' (2014) 24 SchweizerischeZeitschrift fürinternationales und europäisches Recht 69, 75-76. 
makes the example that a deconstructivist, if he or she is honest, needs to acknowledge that 'I do deconstruction because I associate it with the kinds of friendship, literature and cinema that I like.' 195

Because Kennedy and Koskenniemi focus on international law as an argumentative practice, they do not frame their critique as pertaining to legal validity, even though this is how most international lawyers would conceptualise the structural indeterminacy thesis. Every argument that is portrayed as referring to international law is of interest to scholars who understand international law as an argumentative practice. A discussion of the degree of legal determinacy thus focuses on all such arguments. Kennedy and Koskenniemi's main argument about the structure of international legal discourse is based on the perceived shortcomings of (neo-)positivism and (neo-)naturalism regarding their account of legal validity: a naturalist may criticise a pure positivist for not being able to explain the validity of an international legal norm towards a dissenter in a purely consensual way; a positivist may criticise a pure naturalist for being unable to explain the validity of an international legal norm by merely relying on a non-consensual standard. This will be seen in greater detail below. In Kennedy and Koskenniemi's view (neo-)positivists and (neo-)naturalists are both right and wrong regarding legal validity. They are right in criticising the opposed theory as an insufficient ground for legal validity. Accordingly, they are wrong in defending their own account of legal validity against the criticisms raised by the opposite school of jurisprudence. Positivists and naturalists would frame their criticisms of each other as pertaining to problems of the validity of international law. Kennedy and Koskenniemi, however, do not use this terminology. Instead, Kennedy writes of 'the authority of arguments'. ${ }^{196}$

When analysing the conceptions of Kennedy and Koskenniemi, one should distinguish between their modest and familiar claims of the indeterminacy of valid legal norms and their more radical account of the structural indeterminacy of international law. The former is based on a presumption of the validity/ authority of norms, the latter questions this very validity/authority. The use of different terms ('validity' or 'authority') should not be over-interpreted, given that, as has been seen, it stems from the fact that both positivists and naturalists ask other questions than those who understand international law as an argumentative practice, such as Kennedy and Koskenniemi. ${ }^{197}$ Throughout

\footnotetext{
195 KOSKENNIEMI, 'Letter to the Editors of the Symposium' 359-360.

196 KENNEDY, ‘Theses about International Law Discourse', 373-374 (emphasis added).

197 I thank MARTTI KOSKENNIEMI for clarifying the reasons why he and DAVID KENNEDY do not refer to legal validity even though that is how their critique of positivism and naturalism would be framed from the point of view of a positivist or naturalist.
} 
this study, I will frame the structural indeterminacy thesis as a claim about the impossibility of finding grounds of the validity of international law. The only exception are parts of the present section in which Kennedy's own terminology will be used. This choice of wording makes Kennedy and Koskenniemi's critique more accessible to most international lawyers, who continue to conceptualise the problem from a positivist or naturalist point of view. In other words, jurists who understand international law as stemming from legal sources instead of constituting an argumentative practice will find it more straightforward to think of the structural indeterminacy thesis as referring to the grounds of legal validity.

\section{II.A.4.ii The Structural Indeterminacy of International Law: David Kennedy}

Kennedy argues that no stable international legal argument can be made. This does not mean, however, that anything goes. To the contrary, good arguments in international law have an internal coherence and can be highly persuasive. Kennedy's claim is that even skilful international legal argument cannot answer the questions that are posed by legal cases. ${ }^{198}$ The underlying reason is identified in the existence of a fundamental dilemma: that States simultaneously find the source of their identity and a threat to their existence in international society. This tension between autonomy and cooperation lies at the root of every doctrinal conflict.199 'Metaarguments' formulated in the language of either sovereign autonomy or international community cannot solve the conflict. Arguments referring, for instance, to the 'nature' of sovereignty or the 'nature' of the global co-operative system are circular because the task is precisely to figure out what the nature of a particular relationship should be. Such 'metaprinciples' are unable to select among different types of interaction in the relationship between States. 200

Kennedy holds that even though many legal arguments can be reversed, it is not a process of total confusion. It would be wrong to conclude that any argument can be used to lead to any conclusion. International legal argument follows a non-random structure, even though it allows for incompatible

198 KENNEDY, 'Theses about International Law Discourse', 357-358.

199 Ibid 361-362. The same idea, on the level of individuals, is expressed in UNGER, Knowledge and Politics, 191-235; and in KENNEDY, 'The Structure of Blackstone's Commentaries', 211-212.

200 KENNEDY, 'Theses about International Law Discourse', 373; this is a familiar critique, as, for instance, put forward by DUNCAN KENNEDY. KENNEDY, 'Form and Substance in Private Law Adjudication', 1732. 
results: ' $\mathrm{A}+\mathrm{B}=\mathrm{C}$ and $\mathrm{A}+\mathrm{B}=$ not $\mathrm{C}$. Still it is clear that the combination of $\mathrm{A}$ and $\mathrm{B}$ is related to $\mathrm{C}$. Under no circumstances does $\mathrm{A}+\mathrm{B}=\mathrm{D}$, or $\mathrm{E}$, etc.'201 That international law is indeterminate does not mean that the structure of international legal argument is arbitrary.

Kennedy's well-known legal indeterminacy thesis refers to the grounds of authority of international law (recall that legal positivists and natural lawyers would frame it as a question of legal validity rather than 'authority'). Arguments about the authority of international legal norms face the dilemma that they cannot simultaneously be rooted in sovereignty and constitute a normative order that is independent of sovereign will. ${ }^{202}$ Such arguments have to refer either to State consent or to some non-consensual norm (based e.g. on justice, systemic considerations, or rationality). These grounds are mutually exclusive. A norm is authoritative either because States have consented to it or because of a non-consensual reason that overrides consent. If consent is the source of authority, by definition, it must overrule other sources of authority. If a norm derives its authority from divine justice, or any other non-consensual origin, it is irrelevant whether States consented to it or not. However, both positions are unstable: a purely consensual approach cannot explain why a dissenter should still be bound without reference to a non-consensual norm (e.g. pacta sunt servanda). A purely non-consensual approach is unable to justify the content of its norms unless it refers back to consent (e.g. pacta sunt servanda derives its authority from the VCLT, which itself is based on consent). These are the criticisms raised against pure positivism and naturalism. ${ }^{203}$

The fact that consensual and non-consensual arguments are mutually exclusive is rarely faced in international legal discourse. Instead, a common rhetorical strategy consists of interpreting consensual arguments in a nonconsensual way and vice-versa. The result is an interminable oscillation between them. ${ }^{204}$ Both rhetorics need to co-exist, distract from each other's fundamental problem, and thereby create a sense of taking seriously both State

\footnotetext{
201 KENNEDY, 'Theses about International Law Discourse', 366.

202 DAVID KENNEDY, 'A New Stream of International Law Scholarship' (1988) 7 Wisconsin International Law Journal 1, 30; DAVID KENNEDY, 'When Renewal Repeats: Thinking Against the Box' (2000) 32 New York University Journal of International Law and Politics 335, 364 .

203 For numerous examples, see KENNEDY, International Legal Structures, 29-54; KENNEDY, 'Theses about International Law Discourse', 374; KENNEDY, ‘A New Stream of International Law Scholarship', 31.

204 DAVID KENNEDY, 'Critical Theory, Structuralism and Contemporary Legal Scholarship’ (1986) 21 New England Law Review 209, 212; KENNEDY, 'A New Stream of International Law Scholarship', 31-32.
} 
sovereignty and the normative demands of an international community. 205 Kennedy uses unilateral declarations as an example. In the 1974 ICJ Nuclear Test case between Australia and France, the Court had to decide whether a unilateral declaration by France was legally binding. ${ }^{206}$ Kennedy shows which argumentative moves would have been possible for both countries. In the example below, 'hard' refers to a consent-based argument while 'soft' indicates a non-consensual one. The example is worth reproducing in its entirety as it perfectly illustrates the oscillation of international legal argument:

'Australia: (Hard)

France: (Hard)

Australia: (Softening) France: (Hard)

Australia: (Soft)

France: (Soft)

Australia: (Hard)
Intent to be bound alone binds. The unilateral declaration is binding.

Intent binds, but we did not intend to be bound. These were merely 'policy statements'. Moreover, if intent binds only we can know our intent.

Intent binds, but must be judged by the evidence. If intent binds, we now change our intent: all statements of intent must reserve the possibility of changing our mind.

This is not possible because it would upset systemic values like the fairness of fulfilling reasonable expectations, or reliance, or of keeping one's promises. We accept those systemic values, but no one should have relied since we were not bound and it was not a promise.

I have ten states here who did rely, including ourselves, and only I can interpret my reliance. You must keep your word regardless of whether you thought it was a promise so that I might rely and be able to consent informedly.

205 KENNEDY, 'A New Stream of International Law Scholarship', 32, 38; KENNEDY, International Legal Structures, 107; KENNEDY rejects both 'neo-positivist' and 'neo-naturalist' positions for hiding the fundamental dilemma while being unable to escape it. 'Neo-naturalists', among whom KENNEDY lists MYRES MCDOUGAL, PHILIP ALLOTT, ALFRED VERDROSS, and BRUNO SIMMA, attempted to solve the dilemma of naturalism by sociological studies into practice to determine the content of norms. Working from the opposite direction, 'neo-positivists', among whom KENNEDY lists HANS KELSEN, HERBERT L A HART, and Georg Schwarzenberger, tried to defend a consensual approach to legal authority while explaining its force against a dissenter. Because both neo-naturalists and neopositivists are forced to rely on each other's positions, they can only shift the problem but not solve it. KENNEDY, 'Theses about International Law Discourse', 379, fns 38-39.

206 ICJ, Nuclear Tests (Australia v France), Judgement of 20 December 1974, ICJ Reports 253, 267-272 (paras 42-59). 
France: (Soft)

Our approach to the systemic values which are implicated here is different. It seems equitable or fair to let us remain unbound.

Australia: (Hard) Accepted and recognized norms are otherwise.'207

While discourse about legal sources, process, and substance is characterised by the impossibility for it to be based on purely consensual or non-consensual grounds, this is hidden not only by the oscillation between these two grounds but also by references among the three discursive areas:

Sources refers us to the states constituted by process and grounded in the violence defined and limited by substance. Process refers us to its origin in sources and its determination in substance. Substance refers us to the boundaries of process, its origins in sources and its resolution in an institutional system of application and interpretation. 208

The moment of authority and practical decision is always somewhere else. When looking at substance, we are referred to sources and process. While analysing process, we realise that sources and substance will answer our queries. The examination of sources, in turn, makes it clear that the magic happens in process and substance. These promises and repetitions generate a feeling of moving forward and a sense of progress. ${ }^{209}$ The discursive moves between sources, process, and substance on the one hand and between consensual and non-consensual rhetoric on the other hand can create a 'feeling of closure and determinacy'. ${ }^{210}$ In this sense, these rhetorics used are neither logically determinate nor indeterminate. Instead, they 'only seem closed when the possibilities for association are not fully utilized. They only seem open and indeterminate when their object is thought to be logical closure.'211 It is noteworthy that because of his focus on legal discourse, Kennedy is interested in how determinate or indeterminate arguments seem. How determinate international legal argument seems depends on what it is compared with, how effortlessly it oscillates between consent and non-consensual bases, and how

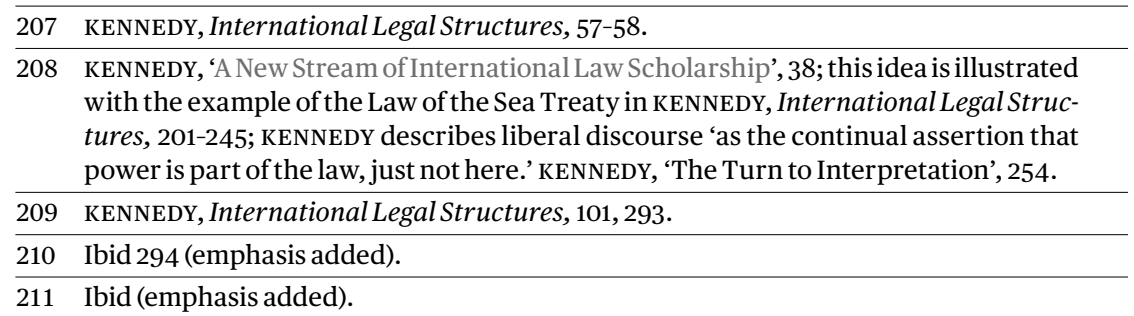


smoothly the elusive authoritative moment is passed on among arguments about sources, process, and substance.

The shifting extent of legal determinacy is illustrated in Kennedy's article 'Spring Break', in which he describes his visit of political prisoners in Uruguay in 1984. The essay illustrates how legal expertise shapes the conversations between Kennedy and the prisoners and how it influences the involved actors' emotions. Kennedy's role as a (human rights) lawyer lets him channel his outrage about the prisoners' torture into a dispassionate language of rights violated. It helps to safely describe the 'barbarian' as 'rights abuser' and the victim as a 'client'. ${ }^{212}$ However, the distinction between chaos and rationality which is upheld by human rights discourse is far from stable. While human rights activists merely think of themselves as responding to a pre-existing irrationality, they play an important part in sustaining its very image. 213 Talk of chaos and discourse about rationality is thus something to construct repeatedly. Hence the point of the article is to illustrate the experience of constantly rediscovering rationality and chaos, determinacy and indeterminacy, instead of formulating an a priori analytical account of the extent of determinacy of law on the basis of logical proof. ${ }^{214}$

This critique of a priori accounts of the extent of legal determinacy, at first sight, seems to contradict Kennedy's analysis of the indeterminacy of international legal argument. After all, in his studies of international legal structures he precisely tries to show why international law is an indeterminate argumentative practice. However, 'Spring Break' focuses on the feelings of closure and openness that actors have when using international law to describe a concrete situation. The constant shifts in international legal discourse may produce a sense of determinacy. This explains why international lawyers are sometimes convinced of an argument. They have a feeling that a solution has been determined by law, even though this results from their inability to see the instability of the position they accepted. The combination of arguments about the authority of international law based on consensual and non-consensual grounds, the internal references among doctrines of sources, process, and substance as well as the upheld image of a clear distinction between chaos and rationality can be distracting enough to generate a sense of determinacy.

In 'Spring Break', just like in his other writings published in the 1980 s that deal with the extent of determinacy of international law,215 Kennedy is not only

212 DAVID KENNEDY, 'Spring Break' (1985) 63 Texas Law Review1377, 1387.

213 Ibid 1414.

214 Ibid 1422.

215 Most importantly, KENNEDY, 'Theses about International Law Discourse'; KENNEDY, ‘A

New Stream of International Law Scholarship'; KENNEDY, International Legal Structures. 
interested in whether international law 'actually is' determinate or not, but also in whether it is perceived as (in)determinate. Hence Kennedy's essays are not self-contradictory because even though he focuses on the inherent instability of legal argument, he does not consider this to be the end of the story. A second step consists of acknowledging that even though no stable argument in international law can be made, this does not mean that in practice actors remain unconvinced about international law's determinacy. In this sense, Kennedy's 'Spring Break' should be mainly understood as a critique of those scholars who stop at the first point of the analysis and take it to be the only one of importance.

Kennedy is aware that the perception of actors involved in legal situations may differ. Not every single legal argument will be deconstructed as being fraught with the problems of pure naturalism or pure positivism, even though this could convincingly be done. The indeterminacy of international law is experienced only in some cases. In other words, international law ends up being perceived to be at most locally, but not globally, indeterminate. Kennedy's conversation with members of the U.S. Army in Iraq illustrates this. While unable to give a straight answer to the question of how many civilians can be killed as collateral damage under the ius in bello when targeting an enemy combatant, the officers were able to come up with some clear cases. Twenty-five women and children are, in the judgement of a U.S. Corporal, too many to be justified for the killing of one Iraqi combatant. They thus perceive the law of armed conflict to be at most locally indeterminate, i.e. able to clearly determine some 'easy cases'. ${ }^{216}$ Once again, this should not be read as a contradiction to Kennedy's claim that international law is globally indeterminate. The potential for deconstructing every international legal argument exists, but is rarely used in practice. This distinction between the global indeterminacy of international legal argument and the perception in practice of international law as merely being locally indeterminate will be discussed in the second main part of this study (II.B).

Kennedy's indeterminacy thesis is somewhat elusive, as he claims that international law 'is' globally indeterminate while emphasising that such $a$ priori indeterminacy theses cannot meaningfully be put forward. I have argued that these claims should not be read as self-contradictory. Instead, they make the valuable point that there seems to be a relevant distinction between abstract (in)determinacy theses and how international lawyers perceive the constraining force of law. In Part II.B, I will discuss the crucial importance of this distinction. In what follows, the focus will be on the consequences Kennedy draws from his indeterminacy thesis. 
While Kennedy mainly focused on showing why international legal argument is globally indeterminate in the 1980 s, his research has since been devoted to the consequences thereof. Because of law's openness and the necessity of making decisions based on non-legal considerations, Kennedy's research focus shifted to the underestimated role of experts. Kennedy criticises (international legal) experts for pretending, or even believing themselves, that they are not making crucial decision but are simply interpreting and arguing about decisions others have already taken. The indeterminacy of international law, combined with its perceived higher degree of determinacy, allows experts to cloak their power. ${ }^{217}$ In the ius in bello, international humanitarian law experts tend to either push responsibility up to the political level or down to formal rules. It is not the military lawyers who decide whether civilians will die or not, but the determination is seemingly always made elsewhere. In this sense, international humanitarian law supports the collective psychological denial by humanitarians and military lawyers of playing a crucial part in decisions about life and death. The ius in bello helps them escape responsibility. ${ }^{218}$ The evaluative language of international humanitarian law is used as a substitute for other judgements. It gives the impression that a thorough legal analysis takes everything necessary into account. This legitimises warfare as a civilised activity, thereby setting personal ethical responsibility aside.219

Because law is less determinate than is commonly assumed, we tend to underestimate the role of legal experts. Parliaments and governments are seen as the places where the most important political decisions happen, where wealth and power are distributed. As we believe experts who portray their decisions as compelled by their field of knowledge, "[w]e remain subjects of an invisible hand-not that of the market, but of expertise which denies its politics.'220 It is thus not surprising that Kennedy is sceptical about proposals for a global parliament. He sees it as an outmoded model that might even be part of the problem. Due to the global indeterminacy of international law, legislation cannot control the work of experts who interpret and implement it.221

\begin{tabular}{|c|c|}
\hline 218 & KENNEDY, Of War and Law, 146-147. \\
\hline 219 & Ibid 141-143. \\
\hline 220 & $\begin{array}{l}\text { KENNEDY, 'Challenging Expert Rule', 24. According to KENNEDY, international law- } \\
\text { yers understand their discipline as having arisen, and now being distinct, from the } \\
\text { chaos of politics. DAVID KENNEDY, 'Autumn Weekends: An Essay on Law and Everyday } \\
\text { Life' in Austin Sarat and Thomas R Kearns (eds), Law in Everyday Life (University of } \\
\text { Michigan Press 1995) 191, } 201 \text {. }\end{array}$ \\
\hline
\end{tabular}

221 DAVID KENNEDY, 'Assessing the Proposal for a Global Parliament: A Skeptics View' (2007) 13 Widener Law Review 395, 395-397. 
Hence the 'cult-like veneration' of institutions such as the United Nations, the European Union, and the WTO by academics who study them is misguided. ${ }^{222}$ The assumption that these organisations simply must be defended ignores the fact that international institutions may not only reduce the occurrence of armed conflicts and fight poverty but also play a role in the reproduction of these problems. 223

If all those institutions international lawyers tend to think of as inherently contributing to a better world may also contribute to steps in the wrong direction, what alternatives does Kennedy propose? Recall that Kennedy locates the origin of the inability of international law to determine legal questions in the fundamental dilemma of international social life, namely that States depend on and are threatened by the existence of an international society. This is the underlying reason why law is unable to be rooted in sovereignty while simultaneously limiting it through the demands of an international community. Kennedy thus argues that legal scholars should focus on confronting the underlying fundamental dilemma itself rather than transforming it in unconvincing, ever more complex, and interminable doctrinal arguments. ${ }^{224}$ Mainstream legal scholarship's fascination with analysing technical details about doctrine and theory is, however, a hindrance for this endeavour. 225 International lawyers need to rethink their role. They are not technical advisors but political actors. Therefore, international legal experts need to (re)learn politics instead of trying to escape it. International economic lawyers, for instance, will need to be trained in analysing the social, political, and economic consequences of their decisions. ${ }^{226}$ The first step for international lawyers to shake off their widespread obsession with legal trivialities is to acknowledge their own discretion. The moment international legal experts realise that they do more than merely apply and interpret decisions taken elsewhere is when they grasp their power to go beyond mere technicalities.

222 DAVID KENNEDY, 'Law and the Political Economy of the World' (2013) 26 Leiden Journal of International Law 7,9 .

\begin{tabular}{ll}
\hline 223 & Ibid 38. \\
\hline 224 & KENNEDY, 'Theses about International Law Discourse', 391. \\
\hline 225 & KENNEDY, 'Law and the Political Economy of the World', 9. \\
\hline 226 & $\begin{array}{l}\text { Ibid 34. International economic law not only presents itself as non-political but also } \\
\text { denies that other fields of knowledge may contribute to answering its questions: '[a]ll }\end{array}$ \\
& too often, law offers the opportunity to make policy decisions without confronting \\
& them as naked political alternatives, while nevertheless accepting that no economic or \\
& interpretive analytic is available to determine which way to proceed.' DAVID KENNEDY, \\
& 'Law and Development Economics: Toward a New Alliance' in David Kennedy and \\
& Joseph E Stiglitz (eds), Law andEconomics with Chinese Characteristics-Institutionsfor \\
& Promoting Development in the Twenty-First Century (Oxford University Press 2013) 69.
\end{tabular}


Acknowledging that one's legal interpretation might as well have gone the other direction and admitting that several readings could be right means opening to the pluralism of a professional perspective. ${ }^{227}$ At the instant when one acknowledges one's own free choice, when the world's contradictions render visible the unconvincingness of theories about systemic coherence, international law can be understood as a terrain for political struggle rather than as a refuge from politics. It is in such instances that international law, instead of merely administering, could remake the world.228

While Kennedy appears overly pessimistic at times, it should be noted that in some ways he is way more optimistic than most international lawyers, given that he does not exclude international law from having the potential to fundamentally remake a better world. Similarly, Martti Koskenniemi, despite defending a no less radical version of the structural indeterminacy thesis, has not given up on international law. While Kennedy and Koskenniemi's global indeterminacy theses share the core argument, Koskenniemi develops it by linking international law's inherent contradictions to those of liberalism.

\section{II.A.4.iii The Contradictory Liberal Roots of International Law: Martti Koskenniemi}

Koskenniemi shows that the argumentative structures of international legal discourse can be traced back to the liberal doctrine of politics, which emerged between the $16^{\text {th }}$ and the $18^{\text {th }}$ century as a reaction to the loss of faith in an overriding theological-moral order. ${ }^{229}$ This rejection of principles of natural and divine justice has significant consequences for the organisation of liberal societies: because there is no overriding set of values, individuals are free and equal. They are free to formulate their own beliefs. Because no hierarchy of values exists that would make them comparable, individuals' views are equal. Therefore, the subjectivity of value, liberty, and equality are at the core of liberal thought. The latter two are the consequences of the former. However, to maintain social order, occasionally, an individual's will has to be overruled. Hence the core difficulty of liberalism is to combine social order and individual freedom. In doing so, liberal theory needs to rely on individual ends instead of the objectives of groups because the latter would undermine the central principle of individual liberty. Any justification of a communal order

227 DAVID KENNEDY, 'One, Two, Three, Many Legal Orders: Legal Pluralism and the Cosmopolitan Dream' (2007) 31 New York University Review of Law \& Social Change 641, 644; DAVID KENNEDY, 'Speaking Law to Power: International Law and Foreign Policy' (2005) 23 Wisconsin International Law Journal 173, 181.

228 KENNEDY, A World of Struggle, 255.

229 KOSKENNIEMI, From Apology to Utopia, 71. 
thus must be based on the interests of individuals themselves. In cases where an individual's immediate will is overridden, this has to be justified by referring back to the individual. ${ }^{230}$

The reconciliation between individual freedom and social order can only be achieved through the Rule of Law.231 Due to the status of individuals as primary units of society, subjective consent becomes the only acceptable ground for social order. Overruling individual consent is only legitimate if it is based on formally neutral rules of law that have been created in a democratic process-a process that itself is based on individual consent. A functioning and legitimate social order has to be based on individual consent while also being able to override it. Koskenniemi calls these requirements 'concreteness' and 'normativity'. If the social order is not concrete, i.e. not based on individual consent, it violates the liberal principle of the subjectivity of value. Such a social order would take the shape of a conception of natural justice-a form of order that liberalism rejects as 'utopian'. If the social order is not normative, it cannot overrule individual consent, thereby leading to anarchy. A system lacking normativity can be criticised as 'apologist', given that law collapses into the will of individuals. ${ }^{232}$ Koskenniemi shows that liberal scholars have extended the liberal doctrine of politics to the international level. The principle of 'sovereign equality', as codified in Article2(1) of the UN Charter, reflects the liberal principles of freedom and equality. Analogous to the domestic level, the liberal principle of the subjectivity of value makes the primary units on the international scene-States-free and equal, i.e. sovereign equals. ${ }^{233}$

However, as has been seen in the sub-section on David Kennedy, the fact that an international legal argument cannot simultaneously be concrete (based on consent) and normative (able to override this very consent) is at the root of international law's problems. A purely consensual approach, as an extreme form of positivism, is unable to explain the validity of a norm for a dissenter. If consent is the sole ground of legal validity, international law loses its normativity toward a State which declares that it no longer consents. The liberal premise of sovereign equality makes it impossible to come up with a conception of what another State actually consents to (e.g. some form of rational or

\footnotetext{
230 Ibid 71-80; the most important inspiration for some of these thoughts is UNGER, Knowledge and Politics, $76-81$.

231 KOSKENNIEMI, From Apology to Utopia, 71; KOSKENNIEMI, 'The Politics of International Law', 5, 28; KosKENNIEMI, 'Constitutionalism as Mindset', 25.

232 KOSKENNIEMI, From Apology to Utopia, 17; KOSKENNIEMI, 'The Politics of International Law', 7.

233 KOSKENNIEMI, From Apology to Utopia, 89-94.
} 
enlightened consent, taking into account its long-term interests, etc.). A purely non-consensual approach, such as an extreme version of naturalism, is in direct violation of the principle of the subjectivity of value and thus unacceptable on liberal premises. The problem is that both extreme positions are instable, and combining them is not feasible either as they are mutually exclusive. Koskenniemi shows that this is not only the case with positivism and naturalism but extends to doctrines about sources, sovereignty, custom, and world order as well. ${ }^{234}$ Because of the inability of international law to determine outcomes, legal practice increasingly relies on finding an 'equitable balance'. This, however, seems to undermine the liberal idea of the Rule of Law as it no longer relies on legal objectivity. ${ }^{235}$

The core argument about the indeterminacy of international legal argument will not be further discussed at this point, as it has been analysed in the sub-section on David Kennedy. Two additions are nevertheless in order. The fact that Kennedy and Koskenniemi portray international legal argument as a highly structured practice might give the impression that they do not defend a conception of indeterminacy after all. Such a reading, however, would be mistaken as it would mix up the formal structure of international legal argument with the (in)ability to lead to material solutions. When working as a diplomat at the Permanent Mission of Finland to the UN, Koskenniemi found it striking that none of the academic treatments of international law captured the 'simultaneous sense of rigorous formalism and substantive or political openendedness of argument'. ${ }^{236}$ Even though arguments in international law oscillate between apology (consent-based arguments) and utopia (non-consensual arguments), these patterns are not normative according to Koskenniemi and, to a lesser extent, Kennedy. This structure indeed leads to a feeling of an autonomous legal reasoning and determinacy, but nevertheless, a material justification of legal solutions cannot be achieved. ${ }^{237}$ The most important difference between Kennedy and Koskenniemi in the context of this study is that the former takes the perceptions of international lawyers about the extent of

234 Ibid 515, 573-574.

235 KOSKENNIEMI, ‘The Politics of International Law', 14. For KOSKENNIEMI, international law would only be objective if it were simultaneously concrete and normative: '[i]nternational law is kept distinct from descriptions of the international political order by assuming that it tells people what to do and does not just describe what they have been doing. It is delimited against principles of international politics by assuming it to be less dependent on subjective beliefs about what the order among States should be like. These two delimitations establish what lawyers commonly assume to be the "objectivity" of international law.' KosKenNIEMI, From Apology to Utopia, 16.

236 KosKenNiEMI, From Apology to Utopia, 562.

237 Ibid 68; KENNEDY, International Legal Structures, 294. 
legal determinacy more seriously than the latter. Koskenniemi is more focused on showing that international law is globally indeterminate while Kennedy attaches greater importance to how the extent of determinacy is perceived by academics, diplomats, military lawyers, etc. I will return to this point in Part II.B, particularly in Section II.B.2.

What was left to do for Koskenniemi after having written From Apology to Utopia, which was called the possibly 'last great original treatise in the international law field' by Kennedy?238 It is telling that Koskenniemi's interests shifted from an abstract level to the concrete, institutional level. Whereas in From Apology to Utopia his goal was to show that international law is indeterminate in all branches of international law and independently of the organisations that apply it, in his more recent research on the structural biases of institutions such as the WTO he takes a more nuanced view. In Section II.B.2, I will argue why such a shift from the abstract level to legal practice is necessary for any kind of research dealing with legal indeterminacy.

Moreover, after having dealt with the structure of international law, which is somewhat disconnected from concrete projects of international lawyers, Koskenniemi turned to the history of international law. ${ }^{239}$ Hence in addition to his increased focus on particular institutions, Koskenniemi increasingly concentrated on the micro-level, down to the wishes and fears of individual international lawyers. Even though he still upholds the structural indeterminacy thesis as put forward in From Apology to Utopia, 240 in 2001, Koskenniemi developed the idea of a culture of formalism. Instead of ridiculing formalism as an easily manipulable tool, he maintains that reference to formal arguments can persuade decision-makers to take a distance from their preferences and consider the generality of their positions. ${ }^{241}$ Despite the indeterminacy of international law, the culture of formalism imagines the possibility of constraining power through law. This does not signify that the way back to formalism would still be open. Nevertheless, it means that formalism can serve as 'a culture of resistance to power, a social practice of accountability,

\footnotetext{
238 KENNEDY, ‘The Last Treatise’, 982.

239 MARTTI KOSKENNIEMI, The Gentle Civilizer of Nations: The Rise and Fall of International Law 1870-1960 (Cambridge University Press 2004); MARTTI KOSKENNIEMI, 'Why History of International Law Today?' (2004) 4 Rechtsgeschichte 61; MARTTI KOSKENNIEMI, 'A History of International Law Histories' in Bardo Fassbender and Anne Peters (eds), The Oxford Handbook of the History of International Law (Oxford University Press 2012); MARTTI KOSKENNIEMI, 'Expanding Histories of International Law' (2016) 56 American Journal of Legal History 104.

240 MARTTI KosKenNiEmI, 'The Politics of International Law-20 Years Later' (2009) 20 European Journal of International Law 7,7 .

241 KosKenNiEmi, The Gentle Civilizer of Nations, 501.
} 
openness, and equality (...)'.242 The advantage of framing problems as legal rather than moral ones is that, for instance, the Iraq war can be understood as a wrong done not only to Iraqi individuals but to the international community which upholds international law. ${ }^{243}$

Believing in the structural indeterminacy thesis, therefore, does not necessarily lead to a loss of faith in international law. Simultaneously accepting international law's indeterminacy while upholding the idea of a culture of formalism is reminiscent of Hans Kelsen's balancing act between a 'pure theory' of law and the acknowledgement of law's uncertainties. In what follows, I will argue that Kelsen put forward an early version of the structural indeterminacy thesis.

\section{II.A.4.iv A ‘Crit’ Ahead of Time: Hans Kelsen}

It may seem odd to portray a legal scholar whose aim it was to develop a 'pure' theory of law as an early 'crit'. ${ }^{244}$ However, Kelsen sharply distinguished between the pure realm of jurisprudence and the political aspects of lawapplication. As has already been seen in Section II.A.3, Kelsen understood legal interpretation and fact-ascertainment to be at the root of the indeterminacy of valid law. These comments, however, do not make him a 'crit'. Instead, what matters for this purpose is that in his early publications, Kelsen defended a view that comes close to the structural indeterminacy thesis as formulated by Kennedy and Koskenniemi. In particular, his critique was not directed at the properties of valid norms of international law but at the possibility of legal validity itself. Kelsen later downplayed this radical critique, but as I shall argue, his early views are more convincing.

At the centre of Kelsen's structural indeterminacy thesis is the choicehypothesis (Wahlhypothese), which deals with the question of whether international law has primacy over domestic law or the other way around. Even though Kelsen was a convinced internationalist and pacifist, ${ }^{245}$ he acknowledged that a conception built on the primacy of international law as well as

\footnotetext{
242 Ibid 500.

243 MARTTI KOSKENNIEMI, 'International Law and Hegemony: A Reconfiguration' (2004) 17 Cambridge Review of International Affairs 197, 214.

244 'Crit' is the shorthand term for a member of the critical legal studies movement or someone whose ideas are strongly influenced by it. In KELSEN's case, the use of the term is, of course, a deliberate anachronism.

245 HANS KELSEN, Das Problem der Souveränität und die Theorie des Völkerrechts: Beitrag zu einer reinen Rechtslehre (first published 1920, Mohr Siebeck 1960) 320; BARDO FASSBENDER, 'Hans Kelsen (1881-1973)' in Bardo Fassbender and Anne Peters (eds), The Oxford Handbook of the History of International Law (Oxford University Press 2012) 1171.
} 
one presupposing the primacy of national law are consistent positions. Kelsen considered the choice-hypothesis a political question that could not be answered based on his pure theory of law. Due to his quest for developing an objective science of law, he was forced to factor the primacy decision out of his legal theory. The choice-hypothesis answers the question regarding the reasons for the validity of domestic and international law; the alternative is between two hypothetical basic norms which are the source of legal validity. It is a choice of the 'fundamental basis of our interpretation of the world of law'.246

The main consequence of the primacy of domestic law is that the national legal order can be considered the supreme authority and the State is truly sovereign. The problem is that this conception is only compatible with the sovereignty of the State that is the starting point of the whole construction but is incompatible with the sovereignty of other States. ${ }^{247}$ This view, Kelsen argued in 1920, ultimately leads to the denial of international law, as it rules out anything above the State. The primacy of national law is incompatible with an international legal order binding the State. ${ }^{248}$

The hypothesis of the primacy of international law, on the other hand, is unable to consider States as sovereigns in the sense of bearing the supreme authority. ${ }^{249}$ What is chosen depends on political preferences:

A person whose political attitude is that of nationalism and imperialism may be inclined to accept as a hypothesis the basic norm of his own national legal order; in other words, he may proceed on the basis of the primacy of national law. A person whose sympathy is for internationalism and pacifism may be inclined to accept as a hypothesis the basic norm of international law and thus proceed from the primacy of international law. 250

In his later writings, Kelsen emphasised that the choice-hypothesis does not affect the content of the law, i.e. the rights and obligations of States. He thereby downplayed the importance of the choice-hypothesis regarding the validity

\footnotetext{
246 KELSEN, Principles of International Law (first published 1952, Holt, Rinehart and Winston 1967) 587.

247 Ibid 581-586; KELSEN, Das Problem der Souveränität und die Theorie des Völkerrechts, 317.

248 KELSEN, Das Problem der Souveränität und die Theorie des Völkerrechts, 317.

249 HANS KELSEN, Peace Through Law (University of North Carolina Press 1944) 35; KELSEN, Principles of International Law, 581-582.

250 KELSEN, Principles of International Law, 587.
} 
of international law. 251 While Kelsen in his early publications explicitly discussed the uncertainties surrounding the choice-hypothesis, he did not do so in his later work. ${ }^{252}$ Alfred Rub convincingly argues that while it is true that the choice-hypothesis does not influence the content of legal obligations, it affects the validity of international law. Under the conception of the primacy of national law, international law's validity is rooted in the domestic constitution and can therefore not elude its grasp. In his attempt to deny the dependence of international law on the domestic legal system, Kelsen argued that even under the primacy of national law, a State is obliged by international legal norms once it has recognised them. In other words, Kelsen tried to uphold the thesis of self-obligation in international law, which he had criticised earlier. ${ }^{253}$

This point is crucial for the present purpose of analysing whether the choice-hypothesis is at the root of the structural indeterminacy of international law, i.e. an indeterminacy claim based on the impossibility of upholding an account of legal validity in a non-political way. Kelsen's early view, as defended in Das Problem der Souveränität (first published 1920), is the more convincing one. As explained by Kelsen himself, under the hypothesis of the primacy of national law, the existence of international law is denied as it collapses into the will of the sovereign State. Under this conception, only the sovereignty of the State that is the centre of the whole construction can be recognised. Other States cannot be regarded as sovereigns and thus not as

251 KELSEN'S EARLY VIEW IS EXPRESSED IN KELSEN, Das Problem der Souveränität und die Theorie des Völkerrechts, 317. He downplayed his critique later in KELSEN, Principles of International Law, 586-587; see also KELSEN, General Theory of Law \& State, 387-388; ALFRED RUB, Hans Kelsens Völkerrechtslehre: Versuch einer Würdigung (Schulthess 1995) 437.

252 JOCHEN VON BERNSTORFF criticises that KELSEN was unable to fully separate his political preferences from his allegedly neutral method. BARDO FASSBENDER and ANDRÁS JAKAB counter that KELSEN was transparent regarding the limited scope of his pure theory and about his political convictions. It appears that KELSEN, at least in his early writings, was indeed fully transparent about his views and did not use his neutral science to advance his own political goals. The only point where KELSEN downplayed the influence of his concessions concerns the choice-hypothesis in his later writings. JOCHEN VON BERNSTORFF, The Public International Law Theory of Hans Kelsen: Believing in Universal Law (Cambridge University Press 2010) 119-121; BARDO FASSBENDER, 'Rezension-Jochen von Bernstorff: Der Glaube an das Universale Recht. Zur Völkerrechtstheorie Hans Kelsens und seiner Schüler' (2003) 78 Die Friedens-Warte 297, 300-301; FASSBENDER, 'Friede durch Recht', 140-141; ANDRÁS JAKAB, 'Kelsens Völkerrechtslehre zwischen Erkenntnistheorie und Politik' in Hauke Brunkhorst and Rüdiger Voigt (eds), Rechts-Staat: Staat, internationale Gemeinschaft und Völkerrecht bei Hans Kelsen (Nomos 2008) 201.

253 HANS KELSEN, 'Die Einheit von Völkerrecht und staatlichem Recht' (1958) 19Zeitschrift für ausländisches öffentliches Recht und Völkerrecht 234, 245; RUB, Hans Kelsens Völkerrechtslehre, 437-438. 
legal equals. Every State has its own legal universe that cannot be combined with those of other States. International law only exists to the extent that States so desire. Given that international law's validity is lost whenever there is a conflict of norms with the domestic legal order, it loses its bite. Kelsen, in his early writings, explicitly stated that under such a conception, international law collapses into power politics. The sovereign State, which under the primacy of its legal order is the only sovereign State in the world, is not restricted by any legal limits but can extend its territorial and material jurisdiction as it pleases. ${ }^{254}$

To illustrate how the primacy of domestic law leads to indeterminacy of international law, assume that an international treaty contains a provision stating that 'vehicles shall drive on the right-hand side' (the purpose of the treaty is to harmonise the traffic rules in order to minimise accidents at the borders). Some years after having ratified the treaty, State A decides to add an article to its constitution which reads: 'vehicles shall drive on the left-hand side'. Under the conception of the primacy of national law, this obvious conflict of norms would be resolved in favour of the domestic constitution. This is because Kelsen's view on conflicts of laws is that if a law contradicts the constitution, this is to be understood as entailing a constitutional requirement to repeal the inferior law which is in contradiction to the constitution. ${ }^{255}$ In our example, this would mean that the international legal norm would have to be repealed, as it is at a hierarchically lower level than the domestic constitution. In other words, it would lose its legal validity. International laws thus cease to be valid at the moment when there is a conflict with domestic law. This is not the case if international law has primacy over national law. Under such circumstances, international law does not collapse into power politics. Hence the necessarily political answer to the choice-hypothesis matters greatly, as it determines concrete legal outcomes. Since a conflict of norms between domestic and international law may arise on any legal question, every international legal norm could potentially lose its validity. The two possible answers to the choice-hypothesis may even lead to contradictory results (obligation to drive on the left or right-hand side), as seen in the above example. Therefore, the necessarily political decision to give primacy to national or international law amounts to a structural indeterminacy thesis. ${ }^{256}$

The parallels between Kelsen's early position and the structural indeterminacy thesis as put forward by Kennedy and Koskenniemi are evident. Even

254 KELSEN, Das Problem der Souveränität und die Theorie des Völkerrechts, 317-319.

255 KELSEN, Reine Rechtslehre, 86.

256 I am grateful to Jochen von Bernstorff for comments on this argument. 
though they framed it differently, the core argument remains the same; if the will of the State is the only ground for legal validity, international law's normativity is lost, and international law collapses into power politics. Kelsen expressed this through the idea of the primacy of domestic law; if State law has primacy over international law, the latter only exists as long as the State so wills. Kennedy and Koskenniemi express the same view through the lens of argumentation; the validity of international law can only stem from arguments based on consent, i.e. the expression of the State's will, or arguments rooted in non-consensual grounds, such as divine or natural justice. A pure positivism, which holds that the only ground of legal obligation in international law, and thus of legal validity, is the consent of States, cannot explain how international law can remain normative once a State has withdrawn its consent. Hence if the choice-hypothesis is answered by giving primacy to domestic law, one has to use consent-based arguments only. The problem in both cases is the same; international law can only 'exist', i.e. be normative, as long as its 'obligations' do not interfere with the State's business. Under such an 'apologist' conception, as soon as international law starts bothering the State, it can be chased away like an annoying fly.

Hence the early Kelsen would have agreed with Kennedy and Koskenniemi that international law loses its normativity if the only ground of validity is State consent (Kelsen would have framed it as a situation in which a State's domestic law has primacy over international law). While they would have agreed on the critique of 'apology', they would have disagreed on the 'utopia' critique, however. While Kelsen cautioned against answering the choicehypothesis by giving primacy to domestic law ('apology'), he openly advocated for giving primacy to international law (what Koskenniemi would call 'utopian'). ${ }^{257}$ Hence there is a disagreement between Kelsen on the one hand and Kennedy and Koskenniemi on the other hand. The latter two would argue that giving primacy to international law would violate one of the central premises of the liberal doctrine of politics, namely the subjectivity of value; if a social order is not based on individual (State) consent, it will take the shape of natural justice, which cannot be accepted under liberal premises. Kennedy and Koskenniemi would thus read Kelsen's call to strive for a world-state ${ }^{258}$ as a 'utopian'259 and dangerous project.

257 KELSEN, Das Problem der Souveränität und die Theorie des Völkerrechts, 317-320.

258 Ibid 320.

259 'Utopian' in the sense in which KOSKENNIEMI uses it, i.e. as unrelated to State behaviour and thus as incapable of demonstrating its content in a convincing way. In other words, as a conception which cannot escape the criticism against naturalism. KosKENNIEMI, From Apology to Utopia, 17. 
The reason why Kelsen envisaged the possibility of a world-state and the primacy of international law is that he deemed it possible to move beyond the State-centric view. ${ }^{260}$ The main difference between Kelsen's view and the one of Kennedy and Koskenniemi is that the latter in some aspects takes the status quo for granted; because international law is based on the liberal doctrine of politics, anything contradicting that doctrine's core principles can be deconstructed, which results in the global indeterminacy of international law. In Section II.B.2, I will argue that Kennedy, and especially Koskenniemi, make too much of the political background scheme which allegedly limits every move in international law. Instead, I will side with Kelsen, who envisaged the possibility for the political background scheme to change.

\section{II.B Critical Analysis of (In)determinacy Theses}

\section{II.B.1 The Creation of Legal Meanings}

The position most widely held by legal scholars, since the beginning of the 1920 if not earlier, has been a belief in local indeterminacy of international law: while some cases have one correct legal outcome, others do not. The main reasons for international law's local indeterminacy are the vagueness of language and uncertainty pertaining to legal interpretation and the ascertainment of legally relevant facts. So far, the focus has mainly been on the uncertainties of law. But what about the certainties? Where does the constraining force of law come from? What makes a case 'easy', i.e. so straightforward that it does not even seem to require any interpretation? A critical analysis of (in) determinacy theses is most productively done by focusing on how meanings are created rather than directly targeting the legal uncertainties.

For the moment, the focus will only be on norms that are presumed to be valid. In other words, this section does not deal with questions relating to the sources of law. Instead, I will concentrate on the meanings of linguistic expressions (2.B.1.i) and on how interpretive communities (2.B.1.ii) resolve uncertainties surrounding legal interpretation (2.B.1.ii.a) and fact-ascertainment (2.B.1.ii.b). Hence in this section I attempt to answer some of the questions raised in Sections II.A.2 (linguistic indeterminacy) and II.A.3 (indeterminacy arising from the composition of norms). Global determinacy theses (as discussed in II.A.1) do not need to be addressed because nobody defends such a view. Lastly, the structural indeterminacy thesis (as portrayed in II.A.4) will be dealt with in the following section (II.B.2). 
If law is locally indeterminate, there are 'easy cases', which have one clear legal answer, and 'hard cases', in which the law-applier has some discretion. What exactly is it that determines the correct answer to a legal question? There are four potential origins of meaning: the object of interpretation (e.g. a legal text or an act), the author of the object, the individual interpreter, or the community in which the interpretation occurs. ${ }^{261}$ I will discuss all four potential candidates, reject the first three, and argue that meanings are created within and between the fourth-i.e. interpretive communities. The first candidate to be discussed is the object of interpretation. The question that will be raised, and answered negatively, is whether (legal) texts contain an essence of meaning.

\section{II.B.1.i Linguistic Indeterminacy: The Contextual Meaning of Texts}

As outlined in the section on linguistic indeterminacy, despite appearances to the contrary, it is argued by no one-not even by deconstructionists-that linguistic expressions are globally indeterminate in a particular context; an 'elephant' is clearly not a 'cigarette'. Instead, in the end everyone agrees with Hart's common wisdom that linguistic expressions have a core of settled meanings within a particular context. Despite this consensus within legal theory, the outward show of legal reasoning sometimes seems to imply that words themselves contain the key to clarifying their disputed meaning.

It is common to refer to the 'ordinary meaning' of words when interpreting international law. Article 31(1) of the VCLT, to which international lawyers feel compelled to refer when interpreting international law, ${ }^{262}$ postulates: '[a] treaty shall be interpreted in good faith in accordance with the ordinary meaning to be given to the terms of the treaty in their context and in the light of its object and purpose.' The ICJ and the WTO Appellate Body emphasise that interpretation must 'above all' be based on the text of the treaty. ${ }^{263} \mathrm{How}$ ever, international courts do not neglect that linguistic expressions should be understood in their context. This was already pointed out by the PCIJ264

\footnotetext{
261 PEAT and WINDSOR, 'Playing the Game of Interpretation', 9.

262 KLABBERS, 'Virtuous Interpretation', 24.

263 ICJ, Territorial Dispute (Libya v Chad), Judgement of 3 February 1994, ICJ Reports 6 , 21-22 (para 41); ICJ, Legality of the Use of Force (Serbia and Montenegro v Belgium), Judgement of 15December 2004, ICJ Reports 279, 318 (para 100); WTO Appellate Body, Japan-Taxes on Alcoholic Beverages, 1 November 1996, Appellate Body Report, WT/DS8/ AB/R, 11-12; WTO Appellate Body, United States-Import Prohibition of Certain Shrimp and Shrimp Products, 12 October 1998, WT/DS58/AB/R, para 114; the WTO Appellate Body has even been accused of having a 'textual fetish'. DOUGLAS A IRWIN and JOSEPH H H WEILER, 'Measures Affecting the Cross-Border Supply of Gambling and Betting Services (DS 285)' (2008) 7 World Trade Review 71, 89-95.
}

264 PCIJ, Competence of the International Labour Organization in Regard to International Regulation of the Conditions of Labour of Persons Employed in Agriculture, Advisory Opinion of 12 August 1922, Series B, No 2, 8, 23 (1922). 
and repeated by the ICJ: '(...) the first duty of a tribunal which is called upon to interpret and apply provisions of a treaty, is to endeavour to give effect to them in their natural and ordinary meaning in the context in which they occur.'265 The problem, however, is that 'context' is understood in the narrow sense of the VCLT. When interpreting the terms of a treaty in their context pursuant to Article 31(1)-(3) VCLT, law-appliers are required to look at the 'entire text of the treaty' and beyond to other relevant instruments.266 Put differently, the terms of a treaty are interpreted by looking at other terms. ${ }^{267}$ In the present section, I shall argue that context is necessary to grasp the correct meaning of linguistic expressions but that the reductionist understanding of context as merely referring to other terms employed within the same treaty and in other legal documents should be questioned. Trying to clarify words with more words ultimately cannot answer interpretive questions and is bound to end up in an infinite regress.

That language itself does not contain any meaning and that its meaning is instead constructed by a certain community is a point commonly made. ${ }^{268}$ What we call a 'garbage can' or a 'bin' could also be called a 'penguin'. In this sense, language dictionaries are simply statistical reports of how words are employed by most people. Such usage has nothing to do with what is demanded by some linguistic essence. 269 The fact that no such linguistic essence is at play, however, does not mean that words are malleable at will. Recall Hart's classical example: ' $[\mathrm{t}] \mathrm{here}$ will indeed be plain cases constantly recurring in similar contexts to which general expressions are clearly applicable ("If anything is a vehicle a motor-car is one") but there will also be cases where it is not clear whether they apply or not.'270 That a 'motor-car' is plainly a 'vehicle' is the case because this is how these words are currently used by most people. It may be that in the future we will call some cars 'penguins'. To refer to certain cars as 'penguins' may even turn into a straightforward application of the word 'penguin'. This does, however, not mean that no interpretation is needed in

265 ICJ, Competence of the General Assembly for the Admission of a State to the United Nations, Advisory Opinion of 3 March 1950, ICJ Reports 4, 8 (emphasis added); see also ICJ, Constitution of the Maritime Safety Committee of the Inter-Governmental Maritime Consultative Organization, Advisory Opinion of 8June 1960, ICJ Reports 150, 158.

266 OLIVER DÖRR, 'Article 31: General Rule of Interpretation' in Oliver Dörr and Kirsten Schmalenbach (eds), Vienna Convention on the Law of Treaties: A Commentary (2nd edn, Springer 2018) 582.

267 This narrow textualism of the VCLT has already been criticised in MCDOUGAL, 'The International Law Commission's Draft Articles upon Interpretation'.

268 See Section II.A.2.

269 STANLEY FISH, 'Intention Is All There Is: A Critical Analysis of Aharon Barak's Purposive Interpretation in Law' (2008) 29 Cardozo Law Review 1109, 1123.

270 HART, The Concept of Law, 126. 
'easy cases' where the term seems to be applied 'automatically'. Instead, there is simply such a widespread agreement on how to use the word that the interpretation does not seem to be happening at all. It would, however, be a mistake not to recognise that the use of a term for a certain object always requires interpretation. ${ }^{271}$

While the proposition that meaning does not stem from some linguistic essence but from usage is relatively uncontroversial, the claim that language can only be properly understood by resorting to extra-linguistic elements and context is less commonly acknowledged.272 Despite the critique by McDougal and others outlined above, ${ }^{273}$ the view that words have an 'ordinary meaning' that can be established independently of its context is still implicit in the outward show of legal reasoning. This is evidenced by the occasional reference to language dictionaries by international courts and tribunals, given that such invocations of dictionaries disregard the fact that the meanings of words depend on the contexts in which they are used. In the Oil Platforms case, for instance, the ICJ referred to a language dictionary to determine the ordinary meaning of the word 'commerce'. ${ }^{274}$ In a WTO panel report, the word 'sporting' was looked up in order to determine whether it includes gambling. ${ }^{275} \mathrm{~A}$ former member of the WTO Dispute Settlement Body even referred to The Shorter Oxford Dictionary as 'one of the covered agreements'.276 Although international courts have frequently referred to language dictionaries, 277 this has been criticised by international judicial organs. ${ }^{278}$

271 Ibid; MICHAEL S MOORE, ‘A Natural Law Theory of Interpretation' (1985) 58 Southern California Law Review 277, 284-285.

272 FREDERICK SCHAUER, for instance, argues that the meaning of language is acontextual. FREDERICK SCHAUER, Playing by the Rules: A Philosophical Examination of Rule-Based Decision-Making in Law and in Life (Clarendon Law Series 1993) 55-56.

273 See Section II.A.3.

274 ICJ, Oil Platforms (Islamic Republic of Iran v United States of America), Judgement of 12 December 1996, ICJ Reports 803, 818 (para 45).

275 WTO Panel, United States-Measures Affecting the Cross-Border Supply of Gambling and Betting Services, 10 November 2010, Panel Report, WT/DS285/R, 162 (para 6.110).

276 CLAUS-DIETER EHLERMANN, 'Six Years on the Bench of the "World Trade Court": Some Personal Experiences as Member of the Appellate Body of the World Trade Organization' (2002) 36 Journal of World Trade 605, 616.

277 ICJ, Kasikili/Sedudu Island (Botswana v Namibia), Judgement of 13 December 1999, ICJ Reports 1045, 1064 (para 30); ECtHR, Golder v United Kingdom, Judgement of 21 February 1975, Series A 18, para 32; ECtHR, Luedicke, Belkacem and Koçv Germany, Judgement of 10 March 1980, Series A 29, para 40; WTO Panel, Canada-Measures Affecting the Export of Civilian Aircraft, 14 April 1999, Panel Report, WT/DS70/AB/R, 176 (para 9.112); WTO Appellate Body, EC and Certain Member States-Measures Affecting Trade in Large Civil Aircraft, 18 May 2011, Appellate Body Report, WT/DS316/AB/R, 280 (para 658).

278 WTO Appellate Body, US-Measures Affecting the Cross-Border Supply of Gambling and Betting Services, 7 April 2005, Appellate Body Report, WT/DS285/AB/R, 53-55 
The point here is not to argue that words do not have an ordinary meaning. It is merely to criticise the view that the meaning of linguistic expressions can be established independently of their specific context. The method of referring to language dictionaries to determine the meaning of a term entails precisely this mistake; it is all about trying to establish an acontextual meaning of words. In what follows, I will argue that, firstly, linguistic meanings can only be established by taking their context into account and, secondly, context should be understood more broadly than as suggested by Article 31(2) VCLT; instead of understanding context merely as the text which surrounds the words to be interpreted, it includes, amongst other aspects, the assumed intentions of the authors as well as the assumed aim of an utterance.

The necessity of referring to context when interpreting linguistic expressions is illustrated by the following sentence: 'the man chased a dog with a car.' The sentence is grammatically ambiguous, but some readings are nevertheless unlikely, while others are more plausible. Most readers immediately understand the sentence to mean that the man makes use of a car to chase a dog. We understand the sentence like this even though grammatically, it could very well be that the dog drives a car. If the sentence reads 'the man chased a dog with a bone', we likely understand that the dog carries a bone and is chased by the man, even though it could also be that the man makes use of a bone to chase the dog. The reason for our comprehension is not found in the grammatical structure, nor in context understood as mere text; instead it lies in the fact that we have an understanding of the world: dogs like bones, but they definitely cannot drive cars, whereas most men are able to drive a car and some may be mean enough to chase a dog by using one. ${ }^{279}$

Similarly, we are confident about understanding the following two consecutive sentences properly: 'the baby cried. The mommy picked it up.' Without noticeable reflection, we comprehend that the mother picked up her baby, even though the second sentence does not contain a genitive. Moreover, it seems clear that the mother picked up her baby because it cried, although nothing in the sentences indicates that the two occurrences are causally linked. Furthermore, we are equally confident that first the baby cried, then its mother picked it up, despite the fact that no temporal order is indicated.

(paras 164-167); WTO Appellate Body, China-Measures Affecting Trading Rights and Distribution Services for Certain Publications and Audiovisual Entertainment Products, 21 December 2009, Appellate Body Report, WT/DS363/AB/R, 145 (para348).

279 MERILl F GARRETT, 'Does Ambiguity Complicate the Perception of Sentences?' in Giovanni B Flores d'Arcais and Willem J M Levelt (eds), Advances in Psycholinguistics (North-Holland 1970) 51-52; see also BIANCHI, 'Textual Interpretation and (International) Law Reading', 41. 
We might think that we interpreted the two sentences literally, given that no context was available. Context, however, is always available, even when it goes unnoticed because it is so deeply entrenched in our assumptions. In this case, we can only understand the two sentences correctly because we know what a family is, what people do when babies cry, who is usually expected to take care of a crying baby, etc. ${ }^{280}$ Hence attempts to establish the correct meaning of sentences while ignoring their deeply assumed context are futile.

What makes a sentence clearly understandable is its correspondence to idealised cognitive models, which are rooted in shared experiences and knowledge. They help to understand why categories do not have fixed boundaries and cannot be understood independently of their context, which includes their assumed purpose.281 The concept 'weekend', for instance, requires an idealised cognitive model of a workweek of five days followed by a break of two days, which together form a week defined as seven days. ${ }^{282}$ A further illustration is the word 'bachelor'. We know that it refers to an unmarried man, but while we agree that James Bond suits the category well, it is clear that neither the Pope nor Tarzan could meaningfully be called bachelors. The definition of a bachelor as an unmarried man is obviously not enough to enable us to use the word correctly. In addition to the definition, we need knowledge of the reasons for the use of the word 'bachelor' within a certain linguistic community. We can correctly classify people as bachelors only if we share the idealised cognitive model of a society in which a man of a certain age usually marries a woman unless there are individual reasons that make marriage impossible. Even though both Tarzan and the Pope are unmarried men, they cannot meaningfully be described as bachelors, as neither of them has the possibility to marry. The rationale for using the word 'bachelor' is absent in these cases. The literal definition of a bachelor can thus only be meaningfully applied by understanding the context surrounding its application. ${ }^{283}$

Idealised cognitive models help explain why the same concept can be given different meanings when interpreted in the context of different branches of (international) law. One example is the word 'arbitrary'. Article 6 ICCPR,284

280 HARVEY SACKS, ‘On the Analysability of Stories by Children' in Roy Turner (ed), Ethnomethodology (Penguin Education 1974) 216-218.

281 GEORGE LAKOFF, Women, Fire, and Dangerous Things: What Categories Reveal about the Mind (University of Chicago Press 1990) 68-76; STEVEN L WINTER, A Clearing in the Forest: Law, Life, and Mind (University of Chicago Press 2001) 234; GEORGE LAKOFF and MARK JOHNSEN, Metaphors We Live By (University of Chicago Press 2003) 269.

282 LAKOFF, Women, Fire, and Dangerous Things, 68-69.

283 Ibid 70; see also BIANCHI, 'Textual Interpretation and (International) Law Reading', 42-46.

284 International Covenant on Civil and Political Rights, 999 UNTS 171, 23 March 1976. 
Article 4 ACHR,285 and Article 4 ACHPR 286 all guarantee the right not to be 'arbitrarily deprived of life'. The commentary on Rule 55 of the ICRC's study on customary international humanitarian law declares that in the context of humanitarian relief operations 'consent [by the host State] must not be refused on arbitrary grounds.'287 Even though in both instances the word 'arbitrary' is used, understanding what the word signifies in an isolated manner helps very little in comprehending what it means in international human rights law and international humanitarian law, respectively. A rule can only be understood in its context, which includes its assumed purpose.

Legal formalists ignore this by overestimating the 'acontextual autonomy of meaning' 288 of language. For Frederick Schauer, a proponent of legal formalism, a rule is defined by the relative inflexibility of its language and can be distinguished from its purpose. ${ }^{289} \mathrm{He}$ raises the question of whether the rule not to bring 'live animals on the bus' would also prohibit carrying three live goldfish in a sealed plastic bag on a bus. The answer for Schauer is that it would be prohibited, given that goldfish are literally animals. The underlying reason is that rules should not be mixed up with their purposes, as this would lead the very concept of rules to collapse. ${ }^{290}$ The example gets even more absurd once we recognise that humans are usually classified as animals as well. A literal interpretation would thus prohibit human beings from boarding a bus. The mistake legal formalists make is to assume that a literal interpretation, i.e. an interpretation purely based on the linguistic properties of words, is enough to determine the meaning of rules. This ignores that categories such as 'animals' and 'bus' work against the background of idealised cognitive models, which are based on our knowledge of the purpose of a bus, the potential disturbance caused by certain animals to other passengers, and the fact that goldfish in a bag clearly do not disturb anyone. ${ }^{291}$

Hersch Lauterpacht already convincingly argued against merely analysing a legal text instead of taking the parties' intentions into account. ${ }^{292}$ As the example of the goldfish shows, we cannot meaningfully separate the words

\begin{tabular}{ll}
\hline 285 & American Convention on Human Rights, 1144 UNTS 123, 18July 1978. \\
\hline 286 & African Charter on Human and Peoples' Rights, 1520 UNTS 217, 27June 1981. \\
\hline 287 & $\begin{array}{l}\text { JEAN-MARIE HENCKAERTS and LOUISE DOSWALD-BECK, Customary International Human- } \\
\text { itarian Law -Volume 1: Rules (Cambridge University Press 2005) 197. }\end{array}$ \\
\hline 288 & FREDERICK SCHAUER, 'Formalism' (1988) 97 Yale Law Journal 509, 533. \\
\hline 289 & Ibid 532. \\
\hline 290 & Ibid 533-534. \\
\hline 291 & BIANCHI, 'Textual Interpretation and (International) Law Reading', 44-47. \\
\hline 292 & $\begin{array}{l}\text { HERSCH LAUTER PACHT, 'De l'interprétation des traités: Rapport' (1950) 43 Annuaire } \\
\text { del'Institut de Droit International 366. }\end{array}$
\end{tabular}


used to formulate a legal rule from its assumed purpose, i.e. from what we assume was the intent of its author. Only by referring to the intent of the legislator to keep buses clean and prevent disturbances caused by certain animals to humans can we convincingly argue that humans and goldfish are allowed to ride or be taken on buses even though they are both literally animals. Textualists counter that we are governed by laws-written down in the form of texts-, not men, and that therefore in democracies the meaning of law cannot be determined by referring to the intention of the lawgiver. 'Men may intend what they will; but it is only the laws that they enact which bind us.' ${ }^{293}$ This argument, however, assumes a choice which does not exist. When interpreting a legal norm, we cannot choose between what is directly available (an isolated text that contains its meaning) and something speculative (authorial intent). In fact, neither is directly available. If words alone contained their own meaning, the issue of interpretation would not arise in the first place. ${ }^{294}$

As can be seen in the goldfish example, only by assuming the intention of the legislator can a solution be reached that is not manifestly absurd, namely to prohibit humans from riding buses. Stanley Fish provides another example to illustrate this: when driving his father back to his apartment, they approached an intersection with a stoplight that had turned red. His father said: 'go through the light.' These words could, amongst other possibilities, be interpreted to mean 'violate the traffic rules and pass the stop light' or 'after the light turns green, head straight on and don't turn left or right'. Fish correctly understood it to mean the latter-not by virtue of his correct analysis of the linguistic structure of his father's statement but because he correctly assumed his intention. Had they been in a hurry, e.g. because they needed to reach the next hospital as soon as possible, the father's intention would have been assumed to be different. The same sentence would have acquired a different meaning. Once words are heard or read in their context, which includes an assumption of what is intended, they acquire meaning. Texts alone cannot determine meaning. The same sentence ('go through the light') is understood differently because the assumption about the father's intention changed, not because the text is trumped by the father's intention. The text's meaning cannot be trumped by the intention because there is no inherent or plain meaning that emerges from isolated texts. 295

293 ANTONIN SCALIA, 'Common-Law Courts in a Civil-Law System: The Role of United States Federal Courts in Interpreting the Constitution and Laws' in Amy Gutmann (ed), A Matter of Interpretation: Federal Courts and the Law (Princeton University Press 1997) 17 .

294 STANLEy FISH, ‘There Is No Textualist Position' (2005) 42 San Diego Law Review 1, 2-3. 295 Ibid 4. 
This becomes even more obvious if we take another example: after a grave accident, Peter can neither move nor speak. His family visits him in the hospital where he lies motionlessly on a bed. The reason for his inability to speak is his fractured jawbone-fortunately, his brain remained undamaged. When the church bell rings six times, Peter's eyes wander to the television in his hospital room. His father sees this and immediately knows that Peter's favourite sports show is about to begin. Correctly interpreting his son's intention to watch the show, he turns on the television. Again, what counts is not the inherent meaning of the object of interpretation (Peter looking towards the TV), but the context, which includes the assumption of an intention. Declaring that '[w]e do not inquire what the legislature meant; we ask only what the statute means'296 amounts to ignoring that legal meanings cannot be separated from assumed intention. A text that seems to contain an obvious meaning only does so because a context, including an intention, has already been assumed.297 Note the important word 'assumed', which shall be discussed next.

A common critique levelled at intentionalism is the difficulty of empirically figuring out what the lawgiver, which often consists of multiple authors, intended a long time ago. ${ }^{298}$ This well-known criticism is convincing but does not challenge the point made here. The assertion that the meaning of a text can only be established based on context, including an assumption of what the author intended, is not invalidated by the empirical difficulty of accessing the objectively correct authorial intent. Even though authorial intent is a necessary component of the context that has to be taken into consideration when interpreting, there is no objective method to find it. ${ }^{299}$ Since most communication necessarily occurs through language, intentions cannot directly be communicated. Given that subjective intent has to be expressed through the forms that are defined by linguistic conventions, one can never be sure of having fully grasped its correct essence. ${ }^{300}$ Moreover, it is, of course, correct that legislative intent is notoriously difficult to ascertain. The argument made here is not that the objectively correct intention of the author must be found in order to ascribe meaning to an utterance. What I merely argue is that interpretation involves assuming an intention, and that this assumption is based

\footnotetext{
296 SCALIA, 'Common-Law Courts in a Civil-Law System', 17.

297 FISH, ‘There Is No Textualist Position', 7.

298 NATALIE STOLJAR, 'Survey Article: Interpretation, Indeterminacy and Authority: Some Recent Controversies in the Philosophy of Law' (2003) 11 The Journal of Political Philosophy 470, 479.

299 FISH, 'There Is No Textualist Position', 15, 19.

300 GARY PELLER, 'The Metaphysics of American Law' (1985) 73 California Law Review 1151, 1162.
} 
on contextual knowledge. A successful assumption of authorial intent can, therefore, not simply be deduced from a linguistic analysis of an utterance. Therefore, any criticisms pertaining to the method of ascertaining intention, convincing though they are, constitute no challenge to the present argument.

While the assumption of authorial intent is a necessary part of interpreting an utterance by a person or institution, there are objects of interpretation that have no author. Schauer makes the following example:

Suppose I go to the ocean and while there notice a group of shells washed up on the beach in a pattern that looks something like C-A-T. I will think then of small furry house pets and not of zeppelins or zebras, despite the fact that in this case there is no user of language whatsoever. My ability to think cat when I see 'C-A-T', and the fact that all speakers of English would have a rather closely grouped array of reactions to that same shell pattern, demonstrates the phenomenon I call semantic autonomy, the way in which language carries something by itself, independent of those who use it on particular occasions. ${ }^{301}$

In such a case, except for superstitious people, nobody would assume an authorial intention of the ocean. Rather, non-superstitious people would accept that there is no author in this case. Yet, 'C-A-T' immediately makes us think of furry pets. Hence objects of interpretation can have meanings independently of any assumed authorial intent. In such cases, however, we are not dealing with the interpretation of communication. Schauer's example does not challenge the claim made above that the assumption of an intention is necessary when interpreting an object that has an author. Without a (superstitious) authorial assumption, the cluster of shells on the beach merely constitutes a random pattern which does not communicate anything.

Schauer, however, makes too much of the fact that he thinks of furry pets when seeing 'C-A-T': his conclusion that 'language carries something by itself', that it has some 'semantic autonomy', is misguided. Schauer's mistake is to think that 'in this case there is no user of language whatsoever'. Obviously, he himself is a user of the English language and is thus able to imagine a furry pet when seeing 'C-A-T'. ${ }^{302}$ Hence it is not necessary to have a 'user' of language in the sense of having an author, but there has to be a 'user' in the sense of an understander. Schauer's wrong conclusion about semantic autonomy seems to stem from his erroneous idea of the relation between speakers and understanders of a language:

301 SCHAUER, Playing bythe Rules, 56.

302 ENDICOTT, Vagueness in Law, 18-19. 
For whatever the source of semantic autonomy is, or whatever name we give it, there is at least something, call it what you will, shared by all speakers of a language that enables one speaker of that language to be understood by another speaker of that language even in circumstances in which the speaker and understander share nothing in common but their mutual language. 303

However, there is no 'semantic autonomy', because it is impossible for a speaker and an understander to communicate in the same language without any further common knowledge. If someone had never seen, or heard of, the animal that we call a cat, they would be unable to use the linguistic expression because this includes applying the word 'cat' to the correct animal. Two people therefore cannot communicate about cats unless they share at least some knowledge about them. ${ }^{304}$

The reason why we intuitively tend to believe that linguistic expressions have some inherent meaning, or some semantic autonomy, is that they always come with a context. It is thus easy to get the wrong impression that objects of interpretation contain meanings which merely have to be discovered. The difficulty of separating objects from their context, including authorial intention, however, is evidence that they are inseparable. If people in a theatre clap their hands at the end of a performance, we immediately link the clapping to the intention of paying respect to the performers. We cannot think of these two elements separately. The reason is that we are so confident in our assumption of the audience's intention that we instantly comprehend it as 'applauding'. However, we might also think that people want to scare off some evil spirits, move their hands to relax their muscles, or circulate the hot air around them. This does not only apply to physical or verbal acts but to legal texts as well. It is difficult to distinguish between the words printed on a piece of paper and some intention motivating their formulation. Precisely because we cannot stop ourselves from linking a legal text to the intention of its authors, the claim that texts do not contain any inherent meaning seems counterintuitive and implausible. Our intuition tells us that texts obviously contain meaning. The claim that there is no purely textualist position thus seems radical. But it is not; I will argue that texts do contain meaning, even though their meaning does not stem from within themselves.

Under the above considerations, McDougal was right to criticise the textualist interpretive method proposed by the ILC in preparation of the VCLT.

$303 \quad$ Ibid $55-56$.

304 ENDICOTT, Vagueness in Law, 18-19. 
The Commission's explicit decision not to refer to the intention of the parties as an element distinct from the text was considered unproductive by McDougal. He disputed that the text itself could be presumed to contain the authentic expression of the parties' intentions. ${ }^{305}$ Hence McDougal was disappointed that the ILC's approach understood context, as codified in Article 31(2) VCLT, as being reflected in even more text: the context that can be taken into consideration when interpreting a treaty is found in the treaty's text, preamble, annexes, agreements relating to the treaty, and instruments made by the parties in connexion with the conclusion of the treaty. Neither is the reference to the 'object and purpose' in the VCLT helpful; the ILC's commentary clarifies that the purposive interpretation does not refer to what the parties intended but merely to the 'object and purpose' intrinsic to the text. ${ }^{306}$ In other words, if the text is unclear, read some more text! However, if one cannot go beyond the text, everything depends on the 'ordinary meaning' of the terms used. Based on this analysis, McDougal concluded that '[i]t is difficult to escape the assessment that the International Law Commission's entire formulation of principles of interpretation is based upon a conception of "ordinary meaning" which is impossible of application.' 307

So far, I have looked at two potential candidates for answering the question of what determines the meaning of legal norms: the object of interpretation itself (such as a legal text or a physical or verbal act) and the intention of the object's author. Both candidates, however, turn out to be unable to play this role: I have argued that legal texts do not contain any acontextual meaning. An important component of context is what is assumed to be the intention of the object's author. I have suggested that assuming an authorial intention is crucial when interpreting a legal text. However, there is no objectively correct method to ascertain such intentions. Therefore, an intention has to be assumed. Given

305 MCDOUGAL, 'The International Law Commission's Draft Articles upon Interpretation', 992.

306 Ibid 993-994; report of the International Law Commission, UN General Assembly, $21^{\text {st }}$ Session 1966, Official Records, Supplement No 9 (UN Doc A/6309/Rev 1) 51; see Article 31(2) of the VCLT which understands 'context' as solely referring to other texts instead of understanding context in a broader way:

'2. The context for the purpose of the interpretation of a treaty shall comprise, in addition to the text, including its preamble and annexes:

(a) Any agreement relating to the treaty which was made between all the parties in connexion with the conclusion of the treaty;

(b) Any instrument which was made by one or more parties in connexion with the conclusion of the treaty and accepted by the other parties as an instrument related to the treaty.'

307 MCDOUGAL, 'The International Law Commission's Draft Articles upon Interpretation', 995. 
that we have no method to access the objectively correct meaning of objects of interpretation or authorial intent, it becomes clear that meaning has to be conferred on objects of interpretation. In what follows, it will be analysed whether the two remaining candidates, the individual interpreter and the interpretive community, are able to confer meanings on objects of interpretation.

\section{II.B.1.ii Interpretive Communities and the Attribution of Meanings to Objects of Interpretation}

Do individual interpreters confer meanings on legal texts and other objects of interpretation, or is it the community in which an interpretation occurs that does so? Jerome Frank defended the former position, Karl Llewellyn the latter. While Frank emphasised the uniqueness of each interpreter, Llewellyn highlighted the commonalities of specific communities, such as the one of American appellate judges. Frank claimed that due to the idiosyncrasies of each individual interpreter, the law cannot be meaningfully predicted. He argued that even clear and precise legal rules, such as the rule to drive on the right-hand side, could not determine the outcome of a case. ${ }^{308}$ Instead, legal issues are determined by the judge's idiosyncratic perception of which facts are legally relevant. ${ }^{309}$ Llewellyn, on the other side, argued in his later work that the common traditions and a shared professional ethos in the judicial profession are the main determining factors of legal decisions. ${ }^{310}$

In what follows, I shall build on the conclusion reached above that texts in themselves do not contain meaning and that authorial intention is not objectively verifiable. I will argue that the meanings of legal texts are determined not by the individual interpreter, but by the interpretive communities in which the interpretation occurs. Rather than adopting Frank's view, the argument will therefore come close to Llewellyn's idea of professional communities stabilising legal meanings.

In his famous article 'The Invisible College of International Lawyers', Oscar Schachter wrote that the professional community of international lawyers, 'though dispersed throughout the world and engaged in diverse occupations, constitutes a kind of invisible college dedicated to a common intellectual enterprise.'311 The vagueness of the fundamental principles of

\footnotetext{
308 FRANK, Law and the Modern Mind, xxiv.

309 FRANK, “'Short of Sickness and Death"', 547.

310 FRANK, Law and the Modern Mind 120, 124; LLEWELLYN, The Common Law Tradition, 19; see also LLEWELLYN, The Theory of Rules, 139-151.

311 OSCAR SCHACHTER, 'The Invisible College of International Lawyers' (1977) 72 Northwestern University Law Review 217, 217.
} 
international law, such as State sovereignty or pacta sunt servanda, and the fact that contradictory outcomes can be reached based on the same legal rules, may produce an impression of indeterminacy and relativism. This, however, does not mean that international law is without any interpretive constraints. Decisions on competing principles can only be made on the grounds that are shared within the international community of States, rather than based on what an individual lawyer or a single government considers a correct application of international law.312 This idea resembles the concept of epistemic communities, which originates in the international relations theory of constructivism.313 Peter Haas defines an epistemic community as 'a network of professionals with recognized expertise and competence in a particular domain and an authoritative claim to policy-relevant knowledge within that domain or issue area.' 314 Such a community shares, amongst other things, a set of normative beliefs and common standards of validity, i.e. a definition of the criteria for how to validate knowledge in its professional field. ${ }^{315}$ John Ruggie defines an epistemic community as a 'dominant way of looking at social reality, a set of shared symbols and references, mutual expectations and a mutual predictability of intention.'316 Members of an epistemic community use a common, specialised vocabulary that sets them apart from other communities. A shared social and political context provides the background for 'seeing' the world similarly. 317

The related concept of interpretive communities has been increasingly taken up in the more recent literature on international law. ${ }^{318}$ It was initially developed in the field of literary studies by Stanley Fish, who describes it as follows:

[an interpretive community] is not so much a group of individuals who share (...) a point of view, but a point of view or way of organizing experience that share[s] individuals in the sense that its assumed distinctions, categories of understanding, and stipulations of relevance and

\footnotetext{
312 Ibid 220-221.

313 WAIBEL, 'Interpretive Communities in International Law', 149.

314 PETER HAAS, 'Introduction: Epistemic Communities and International Policy Coordination’ (1992) 46 International Organization 1, 3.

315 Ibid.

316 JOHN RUGGIE, 'International Responses to Technology: Concepts and Trends' (1975) 29 International Organization 557, 569-570.

317 WAIBEL, 'Interpretive Communities in International Law', 150.

318 Ibid 147-165; FIKFAK and BURNETT, 'Domestic Courts' Reading of International Norms'; BIANCHI, 'Textual Interpretation and (International) Law Reading'; D'ASPREMONT, Formalism and the Sources of International Law 195-203; VENZKE, How Interpretation Makes International Law, 46-49.
} 
irrelevance [are] the content of the consciousness of community members who [are] therefore no longer individuals, but, insofar as they [are] embedded in the community's enterprise, community property. ${ }^{319}$

The concept of interpretive communities was introduced as an answer to the question of the source of interpretive authority. Those literary scholars who claimed that the source of interpretive authority could be found in the text were embarrassed by the wide disagreement among interpreters; how could it be that questions about the meaning of a text give rise to continuous disagreement among equally competent readers? If the quest for the meaning of a text is like hunting for a buried treasure, why is it always possible to restart the hunt even after the treasure has been found? Meanwhile, those who claimed that individual readers are the source of interpretive authority were embarrassed by the broad agreement on a text's meaning. If everyone can project their own idiosyncratic ideas on the text, how come that there often is agreement on the meaning of a text? The concept of interpretive communities can explain both agreement and disagreement straightforwardly. Agreement occurs when the readers are part of the same interpretive community; disagreement occurs when they are not. Different interpretations by the same individual are no challenge either, as one person can belong to several different interpretive communities. ${ }^{320}$

The idiosyncrasies of the interpreter that Jerome Frank believed to be the determining force of legal decisions appear to play a much smaller role. A decision that may seem, at first sight, to be based on one judge's individual values and ways of perceiving the world turns out to depend on shared interpretive strategies. The mental operations individual interpreters can perform are limited by the institutions they are part of. Even when readers seem to be making use of their own interpretive strategies, the source of those strategies is a shared system of intelligibility. ${ }^{321}$ The views and assumptions of individuals can never be entirely their own, given that the common system of intelligibility precedes them and thus delimits the set of possible paths that can be taken by their consciousness. ${ }^{322}$ When people clap their hands at the end of a performance in a theatre, the interpretive strategies available to individuals in the audience are not uniquely theirs. Instead, they are a result of

319 STANLEY FISH, Doing What Comes Naturally: Change, Rhetoric, and the Practice of Theory in Literary and Legal Studies (Duke University Press 1989) 140.

320 Ibid; STANLEY FISH, 'Interpreting the "Variorum"' (1976) 2 Critical Inquiry 465, 484.

321 STANLEY FISH, Is There a Text in This Class? The Authority of Interpretive Communities (Harvard University Press 1980) 331-332.

322 Ibid 320-321. 
the commonly shared understanding of what a theatre performance is for and what intentions may motivate the spectators to make noise by using their hands. The state of being independent of commonly shared assumptions and free to rely on one's own subjective purposes cannot be attained. Frank's suspicion of individual interpreters who purely rely on their idiosyncratic interpretive strategies is thus misconceived. Just as there are no free-standing texts, there are no free-standing readers either. Instead, the minds of readers are constituted by conventional notions, which in turn constitute the object of interpretation. ${ }^{323}$ Hence interpretive authority is found neither in a text (the object of interpretation) nor in the individual reader, but in the community in which the interpretation occurs.

The reason why an interpretive community is best understood as a point of view, rather than as a group of individuals who share such a point of view, is that interpretive authority does not rest with the members of an interpretive community but within their shared ways of organising knowledge. This is illustrated by a single individual who is a member of different interpretive communities; Joe can ascribe different meanings to the same object because he is a member of different interpretive communities. Whether the outcome of an interpretive process is $\mathrm{X}$ or $\mathrm{Y}$ does not depend on whether Joe or someone else interprets the object, but on which commonly shared interpretive strategies are dominant.

There is no understanding that takes place above or beyond situations, given that objects-such as texts-do not possess an inherent meaning that could be understandable outside a situation. Hence understanding is only possible in a context and within an interpretive community. ${ }^{324}$ If people who are not members of the invisible college of international lawyers (whether there is one or several colleges will be discussed in Sub-Section II.B.1.ii.a) were given a definition of the kind 'an armed attack constitutes (...)', they would only partially be able to understand it. Such individuals would only understand it to the extent that they are members of other relevant interpretive communities, such as the one of military experts. However, they would not spot those parts which are important to international lawyers. The reason is that one first needs to understand the general activity, in this case international law, in relation to which the terms can be meaningful. ${ }^{325}$ Only if one has an understanding of the relevant context, including international law's purposes, can one fully comprehend what is meant by the definition.

323 Ibid 332.

324 Ibid 304 .

325 Ibid 304. 
In a well-known anecdote, Stanley Fish tells the story of one of his colleagues at Johns Hopkins University who was approached on the first day of the semester by a student who asked him: 'is there a text in this class?' The professor answered: 'yes; it's the Norton Anthologyof Literature,' whereupon the student replied: 'no, no, I mean in this class, do we believe in poems and things, or is it just us?' 326 The student had previously taken one of Fish's courses in which he defended the position that is adopted here as well, namely that instead of the text or the individual reader, interpretive communities are the source of interpretive authority. This became clear to the professor as the student made her clarification. He did not misunderstand her first sentence in the sense of making a mistake about the meaning imposed by it. There is no such thing. Rather, he was confident that the student inquired about whether there was a reading list based on his prestructured understanding of the situation;327 students at the beginning of the semester are likely to inquire about reading lists. This must have seemed even more likely at a time when they could not access such information conveniently on the university's intranet. Now that almost all students can access the relevant reading lists on their smartphones, the same question might be perceived differently. If the student cannot be seriously asking about whether there is a reading list, the question is more likely to be about the professor's view on the source of interpretive authority. Shared interpretive strategies change over time as the context changes-in this case, the context has even changed slightly since the publication of Fish's book in 1980 . The fact that there is no unchanging and context-free system of meaning does in no way imply that communication cannot occur or that those who communicate cannot be confident of understanding each other. Communication is possible within an interpretive community, and its members are confident of understanding each other correctly. Their confidence is rooted in a set of beliefs that are not idiosyncratic but communal and conventional. ${ }^{328}$

Why, it may be asked, do we use the concept of an interpretive community when every individual has at least slightly different opinions? Even though individuals share the background conventions with other members of their interpretive community, every individual does confer a somewhat different meaning on a given text, given that individuals are usually members of different interpretive communities at the same time. It may thus be said, following authors like Jerome Frank, that there is a degree of subjectivity in interpretation. If the opinions of an individual are the result of the inter-subjective

326 Ibid 305.

327 Ibid 306.

328 Ibid 321. 
background conventions of the several interpretive communities they are part of, and the resulting convictions differ from one person to another, why should we not straightforwardly conceive of these differences as subjective characteristics? Why does the free-standing individual reader, who takes centre stage in Frank's idiosyncrasy approach, completely disappear when we use the concept of interpretive communities? Paul Fry, a student of Stanley Fish, argues that this challenge weakens the idea of interpretive communities without undermining it. 329

However, I consider it crucial to conceptualise differences between individual interpreters as rooted in the background conventions of interpretive communities if we want to properly understand how interpreters are constrained. If we believe that individuals can hold subjective, idiosyncratic ideas, we have to conclude that readers are to a certain extent free to do what they want with a text-namely to the extent that their views on the world are idiosyncratic. However, this would be a mistake since opinions are always constrained by the background conventions of their interpretive communities. As argued above, we cannot grasp an 'individual' opinion independently of the system of intelligibility that precedes it. Understanding individual differences as being rooted in a set of background conventions allows us to dispel the fear of the interpreter who can impose his subjective opinion on the text. This is a relief as it liberates us from the worry that interpretation is unconstrained-a worry that might seem to become particularly acute once we agree that isolated texts (if they could indeed be isolated) contain no meaning whatsoever. Therefore, to think of differences among individual interpreters as the result of different memberships in diverse interpretive communities helps to see that Frank's concerns can be dismissed.

Some may be uncomfortable with the thought that individuals cannot hold entirely idiosyncratic views, as this may seem to diminish the cherished idea of individuality. However, it does not. Every human being is individual in the sense of holding a unique set of beliefs. The concept of interpretive communities only answers the question of where these beliefs emanate from. People do not form their convictions about the world in a vacuum. Instead, such convictions are the product of a combination of memberships in different interpretive communities which is unique to every individual. Biological factors, together with socialisation, determine our beliefs ${ }^{330}$ by increasing the likelihood for us to become a member of particular interpretive communities

329 PAUL H FRY, Theory of Literature (Yale University Press 2012) 321.

330 OUTI KORHONEN, ‘New International Law: Silence, Defence or Deliverance?’ (1996) 7

European Journal of International Law 1, 5 . 
and decreasing the likelihood of joining others. The fact that our beliefs emanate from interpretive communities in no way diminishes the value of individualism; even though all our beliefs can only be expressed within a shared system of intelligibility which precedes them, each individual is still unique because it belongs to a particular combination of interpretive communities. One would set the standards for individuality too high if it were defined as holding subjective views in the sense of opinions that are idiosyncratic and entirely independent of anyone else's convictions. If anyone were to hold such views, they would be unable to communicate these views with others. This would be a pitiful form of individualism.

So far, I have argued that meanings cannot be discovered in the object of interpretation itself or inferred through the intent of its author. Moreover, I have suggested that meanings are not conferred on the object of interpretation by subjective interpreters but are created within interpretive communities. Put differently, meaning is neither objective nor subjective but always inter-subjective. ${ }^{331}$ In what follows, I will focus on what this means for indeterminacies arising from legal interpretation and fact-ascertainment.

\section{II.B.1.ii.a. Legal Interpretation}

An acceptable interpretation is what one can get away with within a particular interpretive community at a specific point in time. This means that interpretation is constrained, as one can only get away with a limited set of interpretive moves. ${ }^{332}$ The constraint is, however, not a function of the stability of the object of interpretation. While it would be most attractive to provide a list of argumentative moves that are accepted in international law, this could only be empirically done with reference to a particular interpretive community at a specific moment in time. 333 What is considered an acceptable interpretive strategy is subject to change, even when a text that actually deals with the accepted tools of interpretation, such as the VCLT, remains unchanged. No interpretation, even one that may appear absurd, is inherently impossible due to its conflict with the text. ${ }^{334}$

\footnotetext{
331 MICHEL ROSENFELD, Just Interpretations: Law between Ethics and Politics (University of California Press 1998) 21.

332 FISH, Is There a Text in This Class?, 343-344. On the moves one can get away with in international law, see KENNEDY, 'Theses about International Law Discourse', 366; DAVID KENNEDY, International Legal Structures, 57-58; KOSKENNIEMI, From Apology to Utopia, 562.

333 For an analysis of, amongst others, the argumentative moves available at the UNHCR and the WTO, see VENZKE, How Interpretation Makes International Law, 72-195.

334 FISH, Is There a Text in This Class?, 347.
} 
As has been established in Sub-Section II.A.3.i, the reason why the rules of interpretation codified in the VCLT ultimately are not themselves a constraint on interpretation is that the VCLT is itself a text. If there is no purely textualist position, the meaning of one text cannot be clarified by using another text. The point is that even though it might seem as if the VCLT itself constrained interpretation, the constraining force originates somewhere else; the free-standing text of Articles 31-33 of the VCLT, if it could be isolated from its use in a particular community, is unable to clarify the meaning of an international treaty.

Ludwig Wittgenstein argued that every rule only gains meaning through conventional use. Hence interpreting one rule with the help of another rule only shifts the problem without solving it: "[a]ny interpretation still hangs in the air along with what it interprets, and cannot give it any support. Interpretations by themselves do not determine meaning.' 335 When referring to Articles 31-33 of the VCLT to interpret an international treaty, we encounter the same challenge at a higher level: how should we interpret the interpretive rules of the VCLT? We could find an answer to this question, but it would equally take the form of some interpretive rules; turtles all the way down. Wittgenstein thus argued that the only way out of this infinite regress is through practice. ${ }^{336}$ He explained that actors learn to correctly grasp the meaning of words (and other objects of interpretation, such as the clapping of one's hands) through a process of socialisation. Understanding the meaning of words requires familiarity with the conventions of the community in which the words are used. ${ }^{337}$ Hence the law itself, isolated from how it is used in practice, does not answer the question of what it means. It is thus not possible to answer the question 'what does the UN Charter require in this instance?' without referring to the practice of a particular interpretive community at a given time. What is a correct or incorrect application of the law cannot be answered outside the practice of a community. 338

Correspondingly, the question of the extent of determinacy can only be meaningfully raised regarding a particular community. This applies to law as well as literature, arts, religious texts, and any other phenomenon that needs to be interpreted. Hence the question 'is international law determinate or indeterminate?' cannot be answered in the abstract. I will argue that a large

\footnotetext{
335 LUDWIG WITTGENSTEIN, Philosophical Investigations (Blackwell 1958) para 198.

336 Ibid para 202; LUDWIG WITTGENSTEIN, On Certainty (Blackwell 1969) para 501.

337 ANTHONY C GRAYLING, Wittgenstein: A Very Short Introduction (Oxford University Press 2001) 96 .

338 INGO VENZKE, 'Is Interpretation in International Law a Game?' in Andrea Bianchi, Daniel Peat, and Matthew Windsor (eds), Interpretation in International Law (Oxford University Press 2015) 366.
} 
part of the (in)determinacy debate in international law has ignored this-including the initial research question of the present study. For now, suffice to say that international law can be determinate or indeterminate depending on the shared interpretive strategies and commonly held assumptions within an interpretive community. The extent of determinacy of international law thus does not depend on, for instance, whether two conflicting but equally correct methods of interpretation are 'available', as, for instance, argued by Kelsen. ${ }^{339}$ Neither does it depend on the availability of conflicting legal principles, as, for example, maintained by McDougal. ${ }^{340}$ Putting forward such an abstract claim entails one of two possible mistakes. The first mistake would be to treat the 'invisible college of international lawyers' as one single interpretive community. Even though international lawyers do share some background conventions, there are numerous interpretive sub-communities, whose interpretations will often differ: human rights lawyers, trade lawyers, military lawyers, etc. Hence one should not assume that all the different interpretive communities international lawyers are members of would deal with a clash of interpretive methods similarly. ${ }^{341}$ The other mistake one may make when analysing the extent of legal determinacy in the abstract is to assume that isolated texts contain some meaning. As has just been shown, this is not the case. Even if two conflicting methods of interpretation 'exist' (i.e. are codified in, for instance, a treaty dealing with interpretation), it is very well possible that one of them will be considered to take precedence over the other in a specific community.

It has, for instance, been argued that particular attention must be paid to purposive interpretations when interpreting the founding instrument of an international organisation. ${ }^{342}$ This argument finds approval in a certain community even though according to the VCLT, several other interpretive methods would be equally applicable. Neither the 1969 nor the 1986 VCLT contains any special interpretive rules regarding constituent instruments of international organisations. The extent of determinacy then depends on what

339 KELSEN, Legal Technique in International Law, 12; KELSEN, The Law of the United Nations, xiv; see also KELSEN, Reine Rechtslehre, 96-97; see Sub-Section II.A.3.i.

340 LASSWELl and MCDOUgal, 'Legal Education and Public Policy', 236; see Sub-Section II.A.3.i.

341 This mistake has most obviously been made by SCHACHTER, 'The Invisible College of International Lawyers'.

342 ICJ, Legality of the Threat or Use of Nuclear Weapons, Advisory Opinion of 8July 1996, Dissenting Opinion by Judge Weeramantry, ICJ Reports 101, 148; IGNAZ SEIDL-HOHENVELDERN and GERHARD LOIBL, Das Recht der Internationalen Organisationen einschließlich der supranationalen Gemeinschaften ( $7^{\text {th }}$ edn, Carl Heymanns 2000) 247; MATTHIAS RUFFERT and CHRISTIAN WALTER, Institutionalisiertes Völkerrecht (CHBeck 2009) 48-49. 
interpretive moves are recognised under the label of 'purposive interpretation' in the community that views it as the primary tool for interpreting constitutive instruments of international organisations. Taking the example of the UN's founding instrument, on an abstract level, it would be possible to refer to the Charter's object and purpose of safeguarding peace and to conclude either that no forcible action can be taken or that a limited use of force is necessary to prevent further hostilities. Nothing within the UN Charter or other international legal documents makes one of these arguments more correct than the other. Within a given interpretive community, however, one of these two conclusions may more clearly be in line with the community's shared assumptions. In this sense, one argument would be correct while the other would be incorrect. Such an assumption could, for instance, be that peace can only be achieved by strictly adhering to a Gandhian spirit of never using violence even when resisting it. If this were the dominant assumption in an interpretive community, the argument that according to the peaceful purposes of the UN Charter a given situation requires strict adherence to Article 2(4) UN Charter, regarding the non-use of force, would carry greater weight than those arguments that ridicule peaceful opposition in the face of violence. What determines the correctness of a legal argument is thus the shared interpretive strategies and assumptions within a community. It is to be noted, however, that this analysis is only able to answer the question of how the law is interpreted within an interpretive community. The question of how members of different interpretive communities come to agree on a legal solution will be raised in Section II.B.3.

Even though objects of interpretation have no inherent meaning, some interpretations are more likely to succeed than others. It is, for instance, highly unlikely-if not entirely impossible-that an interpretive community would assume that the drafters of the UN Charter intended to produce a humoristic and ironic document. There is nothing inherent to the text of the UN Charter that would preclude such a reading. 'WE THE PEOPLES OF THE UNITED NATIONS DETERMINED to save succeeding generations from the scourge of war (...)'343 might, for instance, conceivably be read in such a way. 'They must have been joking', so the unlikely but not impossible argument could go. 'Surely the drafters of the Charter must have known that wars have always been part of human history? Anybody even conceiving of a world in lasting peace cannot be serious. The opening sentence of the Charter's preamble is thus clear evidence of its humoristic and ironic character.' The reason why such an interpretation

343 Charter of the United Nations and Statute of the International Court of Justice, 1 UNTS 16, 24 October 1945, first preambular paragraph. 
seems impossible is not found in the text. Rather, it is exceedingly unlikely that an interpretive community would assume such an authorial intent because almost everybody who deals with international law is aware of the context in which the Charter was drafted: after the atrocities of the Second World War, preventing the recurrence of such events was widely perceived to be an urgent need. Moreover, international lawyers know that diplomatic conferences are not held to crack jokes. Without knowledge of the assumptions that motivated the drafters in San Francisco (and with several other misunderstandings, such as about the aims of multilateral diplomacy), the interpretation of the text as a humoristic document could be successful. If members of an interpretive community had no knowledge about the context of the negotiations that led to the UN Charter-nor about diplomacy, the use of humour, and other things-, it is conceivable that the UN Charter could successfully be interpreted as a joke. Thankfully, international lawyers have a sufficient understanding of the Second World War, diplomacy, jokes, and irony so that we can state with confidence that such an interpretation could not succeed in any known interpretive community. The ridiculousness of the example underscores the seriousness of the matter; texts do not contain any inherent limits to their interpretation. Neither do interpretive rules, such as those codified in the VCLT.

This also applies to so-called gaps in the law. The scope of legal norms cannot be determined by an exact analysis of legal texts. Because meanings are conferred on legal norms, so is their scope. Normative gaps are the result of a limited scope of those norms that are considered valid. The discussion of gaps should not have a prominent part in the debate about the extent of legal determinacy for two main reasons. First, whether there is a gap or not is most productively discussed under the heading of interpretation; only once it is understood that meanings are conferred on legal texts can the illusion be dispelled that gaps result from some essence contained in the materials of a legal system. ${ }^{344}$ Secondly, even if there were universal agreement that international law is a complete system without any gaps, this would not tell us anything about the extent of legal determinacy. If Kelsen were right that 'a positive legal order can always be applied to a concrete case', 345 this would

344 It is not uncommon in academic publications to diagnose the 'existence of normative gaps' only to then show how these gaps should be filled. In lieu of numerous references, DENISE GONZÁLES NÚÑEZ, ‘Peasants’ Right to Land: Addressing the Existing Implementation and Normative Gaps in International Human Rights Law' (2014) 14 Human Rights Law Review 589, 593.

345 HANS KELSEN, General Theory of Norms (first published 1979, Clarendon Press 1991) 366. 
not provide one single answer to every legal question; ${ }^{346}$ law may be applicable to every case without determining any outcomes (because of, for instance, the availability of conflicting principles). Hence, without any contradiction, Kelsen simultaneously upheld a conception of local indeterminacy. ${ }^{347}$

It has been argued that the meaning of a legal text is what an interpretive community confers on it. But what about facts? Can facts constrain how the law is applied by an interpretive community? This shall be discussed in the following sub-section.

\section{II.B.1.ii.b. Fact-Ascertainment}

Those who locate meaning within a text, or within any other object of interpretation such as the act of clapping one's hands, see agreement among interpreters to be evidence of the object's stability. They are forced to conclude that in the case of disagreement regarding the interpretation of a certain object, at least one party must be wrong. The truth is in plain sight, but one of the parties to the disagreement is either too incompetent to recognise it or acting dishonestly. The underlying view is that facts exist in a self-evident form and can simply be referred to once disagreement arises. However, this view has to be rejected, as facts can only be perceived from a certain point of view. Under the approach defended here, disagreements occur between people who use different interpretive strategies. The winner determines what the facts are. Disagreement is thus not solved by reference to the facts, but is the process by which the facts are settled. ${ }^{348}$ If one interpretation prevails over another, this is not because it is more in line with the facts but because the facts are now seen through the lens of the assumptions on which the winning interpretation is based. ${ }^{349}$

Recall that Kelsen argued that in the world of law, there are no absolute, immediately evident facts. Rather than being found, they are created by the judicial organ ascertaining them. ${ }^{350}$ In the same vein, Thomas Franck held that there is no such thing as an objectively true fact; there are only perceptions. ${ }^{351}$

346 KOSKENNIEMI makes too much of KELSEN's statement that there are no gaps in the law by treating it as a global determinacy thesis. KOSKENNIEMI, From Apology to Utopia, 44-45.

347 See II.A.2 and Sub-Section II.A.3.i.

348 For critical views on fact-ascertainment by, amongst others, FRANK, LLEWELLYN, KELSEN, LAUTERPACHT, and D'ASPREMONT, see Sub-Section II.A.3.ii; FISH, Is There a Text in This Class?, 338.

349 FISH, Is There a Text in This Class?, 340.

350 KELSEN, General Theory of Law \& State, 136; KELSEN, Legal Technique in International Law, 12.

351 THOMAS M FRANCK and LAURENCE D CHERKIS, 'The Problem of Fact-Finding in International Disputes’ (1967) 18 Western Reserve Law Review 1483, 1483. 
Whether an object constitutes a relevant fact or not depends on the background conventions of an interpretive community. This point can be illustrated by the example of a maritime boundary dispute adjudicated by an international tribunal. Listing the natural resources of the disputed territory seems to be a straightforward compilation of the evident facts: oil, gas, fish, etc. However, how to classify a coral reef that may, in the future, attract tourists? How will the same coral reef be accounted for if it has spiritual significance for part of the population? Calculating and comparing the value of gas, oil, and fish may be relatively simple as long as nobody attaches any nonmonetary value to these resources. However, how many barrels of oil are equal to the ancient spirit animating the coral reef? It becomes clear that such facts are far from immediately evident. Kelsen was thus right when he explained that facts have to be created by the judicial body deciding the case. How they are created depends on the shared background conventions held by the judges, such as whether spiritual value can be measured in monetary terms. If it can, one State may keep its coral reef while the other gets compensated with more oil and gas. If it cannot, such a compensation is not possible, which may affect how the new border is drawn. Hence even a seemingly straightforward listing of natural resources is not a simple description of immediately evident facts.

One could argue that only some facts are not immediately evident, while others are. Known oil deposits in a disputed territory, for instance, clearly seem to be a legally relevant fact that has to be taken into consideration by a court that is tasked with delimiting the disputed territory by equitably distributing the natural resources. It is true that in the early $21^{\text {st }}$ century, nobody would disagree about the classification of such an oil field as a legally relevant fact in the context of a border dispute. The stability of this conclusion does, however, not stem from some essence hidden in the oil but from the shared background convention within an interpretive community that 'black gold' is something valuable. The reason why this is a straightforward case of fact'finding' is that today oil is still one of the most important resources for the global economy. As soon as oil can be substituted, it will lose its importance for States. Why should a black, sticky liquid be considered a 'natural resource' once it is as useless as the plastic swimming in the ocean that used to be made out of it? Hence the stability of the conclusion stems, amongst other factors, from the shared assumption that oil is valuable and will remain so for at least some time after the boundary dispute has been settled. Many more assumptions are necessary: oil extraction is unlikely to be interrupted by technical or legal problems, customers continue to be willing to buy and burn oil despite its effect on the climate, etc. The point is that the ascertainment of an object 
as a legally relevant fact stems from the background conventions of an interpretive community rather than from the object itself.

This is also the case for the ascertainment of customary international law. The problems surrounding the 'two-element theory' regarding the identification of custom are well-known and do not need to be repeated here. ${ }^{352}$ The main challenge essentially boils down to an ascertainment of facts; which physical and verbal acts of States count as relevant State practice and thus contribute to the formation of customary international law?353 Moreover, the formation of an opiniojuris is based on the same potentially relevant physical and verbal acts of States. ${ }^{354}$ Under the above considerations, such facts do not contain any essence of meaning. Instead, meanings are conferred on them. Whether, for instance, a statement by a foreign minister serves as evidence of State practice and opiniojuris is ultimately not a function of what she or he said. Instead, it is a function of the background conventions of the interpretive community, which confers meaning on these verbal acts. Just as in the case of texts, it seems counter-intuitive to argue that facts do not have any inherent meaning. The reason is that we, as individuals, have never encountered a text or a fact devoid of meaning because we are always part of interpretive communities and therefore have lots of background conventions in our mind already. Intuition is thus not a useful tool for analysing the origin of (legal) meanings.

It is, of course, possible that members of different interpretive communities confer incompatible meanings on the same physical and verbal acts of States. How conflicts between different interpretive communities unfold is the subject of Section II.B.3. The discussion in the present section about facts, and thus about the ascertainment of customary international law, is only to enable us, in a first step, to understand how facts are perceived within an interpretive community. While some facts may be perceived the same way by all interpretive communities in the world, many legal questions concern issues where the respective perceptions of various interpretive communities differ. Hence it will be necessary to look at the process of negotiation of the content of legal norms among individuals who are members in different interpretive communities.

352 On the enigmas of customary international law, see BRIAN D LEPARD, CustomaryInternational Law: A New Theory with Practical Applications (Cambridge University Press 2010) 3-43.

353 HENCKAERTS and DOSWALD-BECK, CustomaryInternational Humanitarian Law, xxxviii.

354 OLIVER DIGGELMANN, 'Anmerkungen zu den Unschärfen des völkerrechtlichen Rechtsbegriffs' (2016) 26 Schweizerische Zeitschrift fürinternationales und europäisches Recht 381,381 . 
Arguing that facts are not simply waiting 'out there' to be discovered but are instead constructed does not mean that the ascertainment of facts is necessarily unstable. To the contrary, since the discovery of oil and its usefulness, it has been correct to label an oil deposit a relevant fact when listing natural resources. Hence there are many 'easy cases' of fact-'finding'. The pitfall consists of forgetting that even the easiest of cases require interpretation, even if it is a straightforward one. Our ability to be utterly sure that oil is a natural resource obscures the source of our confidence, which does not rest in the object itself but in our shared background conventions about it. We are immediately able to understand that oil is valuable and therefore a natural resource. We do not first hear 'oil' and then, in a second step, confer meaning on it. There is no such two-step process. The reason is that the institutional structure in which we are situated only leaves the possibility to hear the utterance in a certain way, as already referring to a particular context, including an assumed purpose. When we hear 'oil', we are unable to seriously ask ourselves: 'does this word refer to a sticky black liquid, gas, a tree, a cigarette, or an elephant?' Interpretive activities are not free because we are always constrained by shared practices and assumptions. Even though there is no textualist position, there is no state in which an utterance can acquire an infinite plurality of meanings. It would indeed be a serious problem if such a free-floating state existed in which linguistic expressions were globally indeterminate. However, there is no such state because every utterance occurs in a situation. We are always in a situation and can thus not express anything outside a situation. This does not mean that because an utterance is embedded in a situation, its meaning will always be obvious. It means that the infinite plurality of meanings is narrowed down to a few alternatives or sometimes even only one option. ${ }^{355}$

\section{II.B.1.iii Interim Conclusion}

The questions posed at the beginning of this section can now, at least partially, be answered. What makes a case 'easy'? Where does the determining force of norms come from? I have argued that the meaning of norms, and thus their determining force, does not come from an essence of the words through which they are expressed. Nor do we have direct access to what the author of an object of interpretation intended. Meanings thus have to be conferred on legal texts. Given that the mental operations of individual interpreters are always limited by the institutions of which they are part, their own interpretations are rooted in shared systems of intelligibility. Hence not the individual interpreter but the interpretive community is the source of the determining force

355 FISH, Is There a Text in This Class?, 306-313. 
of legal texts (as well as of other objects of interpretation). 'Easy cases' seem straightforward because the background conventions within an interpretive community at a particular time make them appear so self-evident as not to require any interpretation. Interpretation, however, is always needed and involved. Hence it becomes clear that even the easiest of cases necessarily involve interpretation. Similarly, if fact-'finding' appears straightforward, this is not because the object (later called a legally relevant fact) simply exists out there, self-evident and ready to be discovered. Instead, it is because the object, seen through the lens of the interpretive community, clearly satisfies the conditions for belonging to a certain category. In the example above, when compiling a list of natural resources in a disputed territory, oil is considered a natural resource not because of some essential characteristics it has but because of a set of shared assumptions that leave no room for doubt about oil being a valuable good.

However, even if there is no purely textualist position, it is by no means irrelevant what is written in a text, such as in the VCLT. The reason is that practice in interpretive communities is relatively stable. What was considered a purposive interpretation at the moment of the adoption of the VCLT in 1969 still very much resembles what is considered a purposive interpretation today. The same applies to every concept contained in the VCLT. Practice creates and changes meanings, but change occurs slowly. What we call a 'table' today is unlikely to be called a 'horse' tomorrow or half a century from now, even though radical and rapid change cannot be ruled out. Still, there are no inherent meanings in the words 'table' and 'horse'. The argument that law is indeterminate due to conflicting but equally correct methods of interpretation ${ }^{356}$ is thus incomplete but may give rise to the illusion that it is validated by empirical evidence. It is incomplete because one would need to add that the only relevant level where the 'existence' of equally correct but contradictory methods of interpretation matters is in the practice of interpretive communities, not in the text itself. I have made this argument several times. The claim added here is that an argument that locates the source of indeterminacy in the existence of contradictory methods of interpretation codified in a legal text, such as in the VCLT, may give rise to an illusion; the VCLT contains conflicting canons of interpretation, and what we observe in the practice of international lawyers is this very conflict. Hence, so the misguided argument goes, international law is indeterminate because the VCLT, or any other legal text, enshrines contradictory methods of interpretation. However, such an argument

356 KELSEN, Legal Technique in International Law, 12; KELSEN, The Law of the United Nations, xiv; see also KELSEN, Reine Rechtslehre, 96-97; see Sub-Section II.A.3.i. 
establishes an incorrect correlation. The source of indeterminacy is found in practice, not in a legal text. The same disagreement that in 1969 led to the codification of conflicting methods of interpretation in Articles 31-33 VCLT ${ }^{357}$ may still exist today between different interpretive communities. Because conflicts between different interpretive communities often persist for a long time, the illusion may arise that indeterminacies arise from a stable text. The argument that international law is indeterminate because of the availability of different canons of interpretation in the VCLT seems correct, but it locates the source of the plurality of possible meanings in the wrong place. Indeterminacy due to conflicting methods of interpretation stems from long-standing disagreements between different interpretive communities, not from the VCLT itself.

This is also how 'hard cases' can be explained; they are not contested because of some 'hard' essence of the object of interpretation, such as a legal text. Instead, 'hard cases' are the result of disagreements between members of different interpretive communities. To understand how disagreements can arise, it would thus be necessary to have an empirical overview of the diverse interpretive communities that exist in international law. Conducting such a study would be highly challenging as there is not merely one 'invisible college of international lawyers' but several different interpretive communities that deal with international law. ${ }^{358}$ Moreover, as argued above, individuals are members of different interpretive communities. An ICJ judge may thus simultaneously share interpretive strategies with other international judges, investment treaty arbitrators, and colleagues from the same professional background and from the jurisdiction in which he was socialised. ${ }^{359}$ Other interpretive communities have been identified in the fields of environmental law, ${ }^{360}$ trade law, ${ }^{361}$ and the law on the use of force. ${ }^{362}$ It is beyond the scope of the present study to analyse which interpretive communities exist in the

357 On the disagreements during the negotiation of the VCLT, see HERBERT W BRIGGS, 'The Travaux Préparatoires of the Vienna Convention on the Law of Treaties' (1971) 65 The American Journal of International Law 705.

358 WAIBEL, 'Interpretive Communities in International Law', 151; see also RUTI TEITEL and ROBERT HOWSE, 'Cross-Judging: Tribunalization in a Fragmented but Interconnected Global Order' (2009) 41 New York University Journal of International Law \& Politics 959, 966.

359 WAIBEL, 'Interpretive Communities in International Law', 153.

360 NEIL CRAIK, The International Law of Environmental Impact Assessment: Process, Substance and Integration (Cambridge University Press 2008) 220.

361 THOMAS COTTIER and MARKUS KRAJEWSKI, 'What Role for Non-Discrimination and Prudential Standards in International Financial Law?' (2010) 13Journal of International Economic Law 817, 818.

362 ANDREA BIANCHI, 'The International Regulation of the Use of Force: The Politics of Interpretive Method' (2009) 22 Leiden Journal of International Law 651, 651-656. 
discipline of international law. Instead, its goal is merely to show what role interpretive communities play in creating legal meanings.

In this section, I have argued that interpretive authority is located in interpretive communities. This helps to comprehend where meanings are created and what is considered a correct application within a given community. However, a crucial element is still missing: what happens between different interpretive communities? What makes an application of an international legal norm correct once all the relevant interpretive communities have been taken into account? We are now in a situation to understand how agreement occurs, but it remains unclear how different views held by members of diverse interpretive communities result in the final decision adopted. This will be answered in Section II.B.3. Before turning to this matter, however, the last and most radical indeterminacy thesis will be examined. So far, in addition to the linguistic indeterminacy claim, indeterminacy theses pertaining to two out of three components of the class of legal reasons have been examined; legal interpretation and fact-ascertainment. The last component of the class of legal reasons is the sources of law. If there is no valid law that can be applied, a case is necessarily indeterminate. The structural indeterminacy thesis, which will be scrutinised in the following section, claims that international law can never be valid and is thus globally indeterminate.

\section{II.B.2 The Limits of the Structural Indeterminacy Thesis}

David Kennedy's and especially Martti Koskenniemi's structural indeterminacy thesis have frequently been discussed. Their works, most importantly International Legal Structures and From Apology to Utopia, have accordingly been criticised from a variety of angles: Kennedy's work gets criticised for focusing too narrowly on the discourse in international law, thereby factoring out ideological differences; for being accessible only to cult initiates; ${ }^{363}$ and for relying on arguments that are 'maddeningly elusive'. ${ }^{364}$ His arguments are said to float on a level of abstraction that is unnecessarily severed from any cultural and historical background. 365 While his analysis is seen as sharp, the results appear empty ${ }^{366}$ and possibly demoralising to some critics. ${ }^{367}$

363 RICHARD FALK, 'Book Review: International Legal Structures' (1988) 28 Virginia Journal of International Law 1065, 1075.

364 Ibid 1067.

365 CARL LANDAUER, ‘Book Review: International Legal Structures’ (1989) 30 Harvard International Law Journal 287, 290.

366 PHILLIP R TRIMBLE, 'Review Essay: International Law, World Order, and Critical Legal Studies' (1990) 42 Stanford Law Review 811, 832.

367 FALK, 'Book Review: International Legal Structures', 1076. 
A frequent critique raised against Koskenniemi's From Apology to Utopia concerns the link he established between liberalism and international law. ${ }^{368}$ In the view of some scholars, Koskenniemi's structural indeterminacy thesis lacks a revolutionary program to tackle the injustices of the world. ${ }^{369}$ Others criticise, amongst other points, that Koskenniemi's deconstructive approach is self-defeating; ${ }^{370}$ that his plea for a politicisation of international law endangers technically skilled lawyers; 371 that Koskenniemi wrongly assumes authority to be the vindication of power; ${ }^{372}$ and that the core argument about consent-based (apologist) and non-consensual (utopian) rhetoric itself is flawed. ${ }^{373}$ This last type of criticism, however, is an exception. Most commentators acknowledge that the core argument of the structural indeterminacy thesis is in and of itself convincing. ${ }^{374}$ Critics rather attack the model's assumptions or consequences.

Discussing each of these criticisms is unnecessary as they either pertain to details or are unconvincing. Instead, I shall elaborate on an objection that has often been superficially mentioned but never further developed: that the structural indeterminacy thesis, despite its persuasiveness, stands in stark contrast to international legal practice. If international law is indeed indeterminate as argued by Kennedy and Koskenniemi, why does it nevertheless 'work' in practice? Jean d'Aspremont points to the fact that despite its theoretical weaknesses, international law provides a set of rules that States comply

368 IAIN SCOBBIE, 'Towards the Elimination of International Law: Some Radical Scepticism about Sceptical Radicalism' (1990) 61 British Yearbook of International Law 339, 350; ULRICH FASTENRATH, 'Besprechung: From Apology to Utopia: The Structure of International Legal Argument' (1990) 31 Archiv des Völkerrechts 182, 184; CHRISTOPH MÖLLERS, 'It's about Legal Practice, Stupid' (2006) 7 German Law Journal 1011, 1013.

369 BALAKRISHNAN RAJAGOPAL, 'Martti Koskenniemi's From Apology to Utopia: A Reflection' (2006) 7 German Law Journal 1089, 1090-1092; ANNE ORFORD, 'A Journal of the Voyage from Apology to Utopia' (2006) 7 German Law Journal 993, 1000.

370 SCOBBIE, 'Towards the Elimination of International Law', 346.

371 JEAN D'ASPREMONT, 'Uniting Pragmatism and Theory in International Legal Scholarship: KOSKENNIEMI's From Apology to Utopia Revisited' (2006) 19 Revue québécoise de droit international 353, 355.

372 ROSALYN HIGGINS, Problems and Process: International Law and How We Use It (Oxford University Press 1994) 15-16.

373 VAUGHAN LOWE argues that non-consensual arguments are not wholly utopian. VAUGHAN LOWE, 'Book Review: From Apology to Utopia: The Structure of International Legal Argument' (1990) 17 Journal of Law and Society 384, 387; LEA BRILMAYER argues that 'concreteness' and 'normativity' do not necessarily contradict each other. LEA BRILMAYER, 'Book Review: From Apology to Utopia: The Structure of International Legal Argument' (1991) 85 The American Political Science Review 687, 687.

374 See, for instance, D'ASPREMONT, 'Uniting Pragmatism and Theory in International Legal Scholarship', 354: '[h]is thesis is cogent and, in many regards, watertight.'; FASTENRATH, 'Besprechung: From Apology to Utopia', 184: 'Die Argumentation ist stringent.' 
with and that operates as a coherent system. ${ }^{375}$ Iain Scobbie criticises Koskenniemi's apparent presupposition that a legal system should be based on a unified and consistent political theory, in this case the liberal doctrine of politics. According to Scobbie, legal systems are rather the segmental expression of diverse policies held by those who practice in the field. ${ }^{376}$ Despite the impression that Koskenniemi ably dissects the paradoxes of the discipline that trouble academics, Vaughan Lowe reminds his readers that legal practitioners care little about international legal theory. Foreign ministries and corporations conduct their interactions on the assumption that international law 'works'-and this is enough for them. ${ }^{377}$ These scholars share the uneasy sense that the structural indeterminacy thesis seems convincing while practice tells a different story. I consider this under-studied set of criticisms pertaining to the relationship between the structural indeterminacy thesis and legal practice the most plausible and serious among the concerns mentioned above. Given that this crucial critique has, surprisingly, never been discussed in more than a couple of sentences, I will elaborate on it in greater detail.

Even Kennedy and Koskenniemi themselves acknowledged the discrepancy between their theory and the practice of people working in the field of international law. In 2006, Kennedy wrote:

It seemed obvious to me that international law was useful-all these people were using it for all kinds of things. And yet the very people most adept at using it were also most adept at unravelling the arguments made by their colleagues for using it this way rather than that way. Somehow they knew, and they didn't know, and somehow the ongoing practice of the profession seemed to depend on keeping that knowledge available and hidden. With these people in mind, it was easy to see that an absolutely airtight theoretical argument demonstrating that their arguments were incoherent or contradictory or indeterminate would not lay a glove on their professional practice. Nor would it disturb them to find that liberal philosophy was split at the root. They suspected as much-and were already disinvesting from both philosophy and whatever they called 'liberalism'. ${ }^{378}$

375 D’ASPREMONT, 'Uniting Pragmatism and Theory in International Legal Scholarship', 357. Moreover, D'ASPREMONT briefly raises the critique that will be spelled out in the present study: ' $[\mathrm{t}$ ]he incompatibility between concreteness (Apology) and normativity (Utopia) can prove to be a compelling problem but only if one systematically sees all international legal disputes from the standpoint of theory.' Ibid 356.

376 scoвBIE, 'Towards the Elimination of International Law', 350.

377 LOWE, 'Book Review: From Apology to Utopia', 384.

378 KENNEDY, 'The Last Treatise’, 988. 
In a similar vein, Koskenniemi in his 2005 epilogue to From Apology to Utopia acknowledged that his indeterminacy thesis is weakened by the fact that international law seems to work in practice:

That critique is only 'weak', however, because little seems to depend on it. For, as I have later realized, international law is not a theoretical discipline. Its 'basis' or core does not lie in theory but in practice-it worksand, notwithstanding a few exceptions, seeking an abstract grounding has never been its strength, or even a characteristic part of it. 379

Both Kennedy's and Koskenniemi's more recent publications evidence a change of focus, away from the indeterminacy thesis towards the work of expertise ${ }^{380}$ and structural biases. ${ }^{381}$ Despite their later concession that theory is of marginal concern to legal practitioners, neither Kennedy nor Koskenniemi have revoked their structural indeterminacy thesis as first put forward in the 1980s. To the contrary, in 2009, Koskenniemi even stated that he felt 'as committed as ever' to the structural indeterminacy thesis. ${ }^{382}$ While I believe that Kennedy and Koskenniemi's new focus on legal practice is one way how research about the extent of legal determinacy ought to be conducted, I will argue that their structural indeterminacy thesis approaches the matter from the wrong angle. The insight that most international lawyers care little about whether legal arguments can be justified based on the liberal doctrine of politics not only weakens the core thesis of Kennedy and Koskenniemi but constitutes the main reason why it must be rejected. In what follows, I will develop this argument by first formulating an example that reveals the tension between Kennedy and Koskenniemi's theory and legal practice. Subsequently, the relationship between theory and practice will be discussed more generally. This will lead to the conclusion that the structural indeterminacy thesis cannot be upheld.

\footnotetext{
379 KOSKENNIEMI, From Apology to Utopia, 600.

380 KENNEDY, 'Challenging Expert Rule'; KENNEDY, 'Assessing the Proposal for a Global Parliament'; KENNEDY, 'Law and the Political Economy of the World'; KENNEDY, $O f$ War and Law; KENNEDY, $A$ World of Struggle.

381 MARTTI KosKENNIEMI, 'The Police in the Temple: Order, Justice and the UN-A Dialectical View' (1995) 6 European Journal of International Law 325-348; MARTTI KOSKENNIEMI and MARJA LEHTO, 'The Privilege of Universality: International Law, Economic Ideology and Seabed Resources' (1996) 65 Nordic Journal of International Law 533-555; MARTTI KOSKENNIEMI, 'Human Rights, Politics, and Love' (2001) 4 Mennesker \& Rettigheter 33-45; MARTTI KOSKENNIEMI and PAÏVI LEINO, 'Fragmentation of International Law? Postmodern Anxieties' (2002) 15 Leiden Journal of International Law 553-579.

382 KoskenNIEMI, 'The Politics of International Law-20 Years Later’, 7.
} 


\section{II.B.2.i The Existence of 'Easy Cases'}

Recall that according to Kennedy and Koskenniemi, each and every argument about international law can be deconstructed. International law is afflicted by global indeterminacy. Consent-based norms cannot explain why a State remains bound to an international legal obligation once it no longer consents to it, except by reference to a non-consensual norm (such as pacta sunt servanda). Non-consensual norms, in turn, have to refer to consensual agreement to dodge the objection that they are made out of thin air ('How do you know what the nature of the international system requires?'-'I know it because States have agreed on it'). Consent-based norms thus cannot explain international law's normativity, while non-consensual norms appear as a utopian project detached from what States agreed on. ${ }^{383}$ I am suggesting that indeed every international legal argument could be deconstructed in this manner. The problem with the structural indeterminacy thesis, however, is that this is more often omitted than actually done in practice, and that this omission matters. I will argue that the reason for this omission is neither laziness nor incompetence of international lawyers. Rather, if anyone is surprised that international lawyers don't deconstruct every international legal argument, this surprise likely stems from upholding a false dichotomy between theory and practice.

If the structural indeterminacy thesis is correct, even those cases which, at first sight, seem to be 'easy' turn out to be indeterminate. Put differently, even cases that appear straightforward can be deconstructed as either apologist or utopian and thus exposed as indeterminate. The following hypothetical example is, at least at first glance, an 'easy case' regarding the prohibition of the use of force in international relations: after years of peaceful relations between Russia and Kazakhstan, in early 2020, 150'000 soldiers, 3'000 tanks, and 500 fighter jets of the Russian army unexpectedly cross the border to Kazakhstan and advance all the way to the capital. On their way, they kill thousands of civilians and unprepared Kazakh combatants, burn down villages, and occupy Nur-Sultan. Within less than a week, a large part of Kazakhstan is under Russian control. Shocked by this news, the Ambassador of Kazakhstan challenges the Russian Permanent Representative at an emergency special session of the UN Security Council in New York:

383 For a more detailed description of the structural indeterminacy thesis, see Section II.A.4. 
Kazakh Ambassador: This outrageous Russian aggression is a clear violation of the prohibition of the use of force as codified in Article 2(4) of the UN Charter.

Russian Ambassador: The Russian Federation is no longer bound by the UN Charter because we have withdrawn our consent.

Kazakh Ambassador: (looking at the Russian Ambassador in disbelief) You must be joking! You know perfectly well that Russia cannot simply withdraw its consent. Have you ever heard of pacta sunt servanda?

Russian Ambassador: We are fully aware of the pacta sunt servanda principle. However, we all agree here that only State consent can be a ground for obligations under international law. Given that we do not consent to the UN Charter anymore, we are not bound by it either.

Kazakh Ambassador: But Article 26 of the Vienna Convention on the Law of Treaties codifies the pacta sunt servanda principle. Russia has expressed its consent by ratifying the VCLT and is thus also bound by the pacta principle.

Russian Ambassador: We recently withdrew our consent from the VCLT as well.

Kazakh Ambassador: The hegemon shows its true face! Russia only complies with international law as long as it is aligned with its interests. All normativity is denied. But international law collapses if it cannot withstand a change of a national position. Cold Russian Realpolitik hides behind the mask of international law.

Russian Ambassador: The bindingness of international legal obligations stems from State consent. This guarantees the sovereign equality of States.

Kazakh Ambassador: Why, in your view, does State consent create binding legal obligations?

Russian Ambassador: Because this is codified in Article 38(1) ICJ Statute, which is generally recognised as listing the sources of international law.

Kazakh Ambassador: But the ICJ Statute cannot derive its validity from itself.

Russian Ambassador: Be that as it may. In any case, consent binds States because this is in the interest of the international community.

Kazakh Ambassador: So Russia now defines what is in the interest of the international community... (laughs bitterly) 
This could go on further. Arguments from both States would have to continue oscillating between a consensual and non-consensual position. Kennedy and Koskenniemi are thus right that even an apparently 'easy case' could be deconstructed in the above manner. However, in international legal practice, this is currently not an available argumentative move. It is simply not done. If anyone actually produced such arguments at the UN, diplomats-just like the Kazakh Ambassador-would react by staring in disbelief and wonder whether their opponent was joking. In today's international legal practice, some arguments are not taken to the extreme as in the above example. If the example seemed odd, I made my point; everyone who is at least somewhat familiar with the arguments put forward in international law immediately recognises that the Russian Permanent Representative's arguments would not be accepted in the discipline. Hence Kennedy and Koskenniemi's toolkit could be used to deconstruct every international legal argument, but this is not what we see in practice.

The fact that State consent and non-consensual norms (such as the interests of the international community or pacta sunt servanda) rely on each other because they are constantly vulnerable to fundamental critique does not seriously trouble legal practitioners. Koskenniemi writes that '[i]f we take liberalism seriously, then international law can only seem an abysmal fraud.'384 This is correct, but the point is that we do not take liberalism seriously-at least not in the way portrayed by Koskenniemi. Most international lawyers do not regard liberalism as the sole basis justifying international legal arguments. And even if they did, most would not accept that under liberal premises, neither consent-based nor non-consensual arguments can be upheld. The fact that the ICJ Statute cannot be the ultimate source of the rule that consent creates legal obligations is recognised in legal theory. ${ }^{385}$ However, the question of the sources of international law is regarded as settled by Article 38(1) ICJ Statute in legal practice and even by a large part of academics, despite the theoretical shortcomings of this view. ${ }^{386}$ In what follows, I will argue why we should take these beliefs seriously.

384 KOSKENNIEMI, From Apology to Utopia, 600.

385 FITZMAURICE recognised this problem and discussed how other international legal scholars, such as Brierly, KELSEN, Verdross, and LAUTERPACHT, tried to deal with it. GERALD FITZMAURICE, 'The Foundations of the Authority of International Law and the Problem of Enforcement' (1956) 19 Modern Law Review 1, 9-13.

386 DIGGELMANN, 'Anmerkungen zu den Unschärfen des völkerrechtlichen Rechtsbegriffs', 383; more generally, vENZKE argues that in the discipline of international law, 'important exceptions aside, theoretical reflection has taken a backseat.' INGO VENZKE, 'International Law and its Methodology: Introducing a New Leiden Journal of International Law Series’ (2015) 28 Leiden Journal of International Law 185, 186. 


\section{II.B.2.ii The Practice of Legal Theory}

Why do international lawyers not deconstruct every position in international law as either apologetic or utopian? As in the example above, this could be done even in apparently 'easy cases' like a full-fledged invasion. One could call practicing international lawyers lazy for not digging deeper, or incompetent in legal theory, but this would be based on a misconception of the relation between theory and practice. Theory does not stand apart from practice but is one of its forms. ${ }^{387}$ Every activity in the field of international law is a kind of practice: the practice of making a statement at the ICJ; the practice of negotiating treaties at the United Nations; the practice of writing doctrinal academic articles; and the practice of thinking about international law in the abstract, i.e. the practice of legal theory.

This is ignored by proponents of the structural indeterminacy thesis. In a nutshell, the structural indeterminacy thesis, especially in the form defended by Koskenniemi, involves three steps: first, it is shown why neither State consent nor non-consensual standards are acceptable grounds of legal validity under the liberal doctrine of politics. ${ }^{388}$ This analysis, in my view, is airtight. Second, international law is portrayed as being based on liberal principles; 389 this is partly correct, but it ignores the fact that most international lawyers are not troubled by the theoretical difficulties of liberalism. Therefore the third step, the conclusion that international law is globally indeterminate, cannot be upheld. It could only be upheld if the liberal doctrine of politics were seen as the sole justifying basis of international law by most participants in the discipline. Moreover, liberalism's theoretical difficulties regarding consensual and non-consensual arguments would need to be widely recognised. However, this is not the case. Accusing international lawyers of laziness or incompetence because they seemingly fail to comprehend that their whole enterprise is based on shaky liberal pillars amounts to overestimating the role of theory. Such an understanding places theory above practice. However, theory cannot go beyond practice and expose the grounds of its possibility 390 because theory, as already mentioned, is not something entirely different. Instead, it is merely a form of practice. ${ }^{391}$ If theory manages to change what it is possible to say and to do in a professional field, such as international law,

\begin{tabular}{ll}
\hline 387 & FISH, Doing What Comes Naturally, 153-155. \\
\hline 388 & KOSKENNIEMI, From Apology to Utopia, 71-89. \\
\hline 389 & Ibid 89-94; KOSKENNIEMI, ‘The Politics of International Law', 4-7. \\
\hline 390 & FISH, Doing What Comes Naturally, 153-155. \\
\hline 391 & Ibid 155.
\end{tabular}


it does so as a form of practice, not as something that stands beyond practice. This in no way denigrates theory. It merely puts theory and practice on the same level. Theory can, of course, be highly influential and fundamentally change a discipline, but it does not do so from any privileged position. Theory cannot automatically impose itself by virtue of its objectively more true essence. It only has an influence if its point of view is accepted within a particular professional community.

Koskenniemi argues that

[b]ecause we are not entitled to presume the existence of a 'metastyle,' it is pointless to be anxious, for example, about the relationship of academic theory/doctrine and diplomatic practice. Incommensurate objects cannot enter into contradiction: a novelist need not face an identity crisis when drafting an income tax declaration. ${ }^{392}$

I submit that this dichotomy between theory and practice is at the root of the problem. Theory and practice are not incommensurate, they are different forms of the same kind of act. Because Koskenniemi presumes this dichotomy, he does not take legal practice seriously enough. To him, the fact that international lawyers rarely question the ultimate source of validity of international legal norms merely seems to 'weaken'393 the structural indeterminacy thesis.

This objection, however, not only weakens the structural indeterminacy thesis but reveals its insurmountable flaw. Approaching the question of the extent of legal determinacy from the point of view of a theory which is detached from other forms of practice cannot lead to valuable insights. It obscures where meanings are produced. A solution is legally determined if its correctness is accepted by the relevant interpretive communities. International law would be globally indeterminate only if Kennedy and Koskenniemi's thesis were widely embraced. But it is not. Usually, arguments are accepted by international lawyers, even though they could be deconstructed if such deconstruction were an acceptable argumentative move. To answer the question of the extent of legal determinacy, one should look at what moves are accepted within the relevant interpretive communities. A theory becomes relevant for the extent of determinacy only if it is widely shared and influences other forms of practice, such as the ways judges, diplomats, and politicians argue about international law. In this sense, International Legal Structures and From Apology to Utopia have only slightly shifted international law towards

392 KOSKENNIEMI, 'Letter to the Editors of the Symposium', 360 (emphasis added).

393 KosKenNiEMI, From Apology to Utopia, 600. 
indeterminacy because they have merely got a few international lawyers to believe in it and apply it in different fields of international legal practice.

The following example will illustrate the relevance of theory for the extent of legal determinacy. Imagine a medieval society in which the validity of law stems from God's will. Among legal scholars and practitioners, there is virtually no disagreement about this given state of affairs. One day, a monk publishes a book in which he skilfully deconstructs the possibility of God's will being the source of the validity of law. Because of the impossibility of finding any stable ground for legal validity, he concludes that law must be globally indeterminate. His book is widely read but has next to no impact on the different fields of legal practice (e.g. on how monks teach, write, and think about law). Scholars and practitioners continue to base their arguments on norms that are presumed to be valid due to God's will. The legal system continues to work as it did before. What is the extent of legal determinacy in this scenario? Despite the skilful arguments in the monk's book, law does not suffer from structural indeterminacy. It still exhibits almost the same extent of determinacy as it did before ('almost', because a few scholars may have been partially convinced by the arguments for indeterminacy). This has nothing to do with the quality of the book-in many ways, it contains a watertight argument. What matters is that it has almost no impact on legal practice, which, to repeat, includes every activity dealing with law. A standard of correctness is always dependent on a set of beliefs. ${ }^{394}$ Something is, therefore, considered correct if it can be brought in line with one's set of beliefs. The monk cannot automatically impose his vision of the world on a community because the arguments in his book are objectively more correct. If we do not have access to an objective truth, we have no choice but to stick to a standard of correctness as accepted within an interpretive community. This equally applies to the question of the extent of legal determinacy. If the vast majority of monks believes that law's validity stems from the will of God, a marginalised theory that disputes this, and concludes that law is indeterminate, is without effect. If the vast majority of international lawyers works on the assumption that State consent can be a ground of legal validity, a theory showing the contrary and concluding that international law is globally indeterminate does not automatically prevail. What matters is which vision prevails in a given community, not which one is objectively more correct (because we have no access to an objective standard of correctness).

It could be objected that the monk's theory is not unconnected to legal practice, as it shows that on the practitioners' own assumptions the validity of

394 FISH, Is There a Text in This Class?, 365. 
law cannot coherently stem from God's will. 395 Therefore, the counter-argument would go, the monk succeeds in showing that law is globally indeterminate. The fact that the monk's critique exposes the dominant legal view's self-contradiction does, I submit, not guarantee the success of his indeterminacy thesis. For the sake of argument, suppose that one of the fundamental principles of the dominant religion is 'you shall never blindly follow any authority', and that this precept is widely treated by the monks as a legal principle as well. In his book, the monk shows how this undermines the blind belief in God's will as the source of legal validity. The monk thus brings to light the self-contradictory basis of the legal system. However, this is not enough to uncover the indeterminate character of law unless legal practitioners realise and react to the self-contradictory nature of the system they previously did not question. The realisation that something about their beliefs is shaky does not suffice to render law indeterminate. Law would only lose its determining force if the majority of legal scholars started regularly and fundamentally questioning every argument whose validity is allegedly based on God's will.

Because the human mind is perfectly capable of holding contradictory beliefs and ignoring their irreconcilable implications, even those legal scholars who recognise the instability of their beliefs about legal validity would not necessarily have to conclude that law is indeterminate for lack of a coherent theory of validity. Recognising the contradiction is not enough. Some legal scholars might even be fully aware that God's will cannot coherently serve as the source of legal validity, but consciously treat it as a legal fiction. The legal fiction of the Kelsenian basic norm fulfils the same function: it factors out a fundamental problem of legal theory and serves as a stabilising ground on which a legal system can be constructed that does not suffer from structural indeterminacy, i.e. indeterminacy for lack of a coherent account of legal validity. ${ }^{396}$ Only if legal scholars refused to work on the basis of such a legal fiction and routinely applied the monk's structural indeterminacy thesis would law be globally indeterminate. But neither the medieval legal scholars nor today's international lawyers do so. Hence international law is not globally indeterminate even though Kennedy and Koskenniemi show on some

395 KOSKENNIEMI tries to show that the objectivity of international law cannot be upheld based on international lawyers' own assumptions: '[b]ut while [liberalism] cannot, on its own assumptions, consistently hold to its objective-formal character, it will have to resort to material principles which it will leave unjustified.' KOSKENNIEMI, From Apology to Utopia, 6.

396 On how KELSEN switched to an understanding of the basic norm as a fiction, see NEIL DUXBURY, 'The Basic Norm: An Unsolved Murder Mystery', LSE Law, Society and Economy Working Papers 17/2007. 
international lawyers' own assumptions that every legal argument could be deconstructed.

Since the extent of legal determinacy depends on what is accepted by the relevant interpretive communities, one should not develop an a priori (in) determinacy thesis that largely disregards practice. As has been seen, David Kennedy made precisely this point in his paper 'Spring Break'397-despite the apparent contradiction to his main work, in which he develops an a priori account of the indeterminacy of international law. ${ }^{398}$ I argued above that Kennedy's work should not be read as self-contradictory but as treating the question of (in)determinacy in two steps: first, by developing the structural indeterminacy thesis Kennedy argues that international law is indeterminate. This claim is independent of empirical evidence from the various interpretive communities in the discipline. This first step is susceptible to the critique raised in the section at hand. In a second step, however, Kennedy acknowledges that the extent of determinacy does not entirely depend his $a$ priori account of indeterminacy. Instead, he takes a closer look at the discursive moves in international law that lead to a 'feeling of closure and determinacy'.399 These argumentative patterns are neither logically determinate nor indeterminate. Instead, they 'only seem closed when the possibilities for association are not fully utilized. They only seem open and indeterminate when their object is thought to be logical closure.'400 Kennedy thus considers both his a priori indeterminacy thesis and the beliefs of international lawyers relevant. Given that Kennedy has devoted a much larger part of his writings to the first step than to the second one, it should not be forgotten that his $a$ priori structural indeterminacy thesis is at the core of his argument while the second step is more of an afterthought. ${ }^{401}$ As should be clear from the discussion above, I am suggesting that only Kennedy's second step is meaningful: an a priori account of legal (in)determinacy is only relevant to the extent that it has an impact on practice, i.e. on how arguments are made in court, during negotiations of international treaties, in developing other theories of international law, etc. If Kennedy's structural indeterminacy thesis were a descriptive account of what international lawyers actually believe and how they really behave, international law would indeed be globally indeterminate. But given

\footnotetext{
397 KENNEDY, 'Spring Break', 1422.

398 Most importantly, such an a priori indeterminacy thesis is put forward in KENNEDY, International Legal Structures.

399 Ibid 294 (emphasis added).

400 Ibid.

401 The only publication in which this afterthought is explicitly developed is KENNEDY, 'Spring Break', 1417-1423.
} 
that most international lawyers do not mind about the impossibility of finding a coherent ground of the validity of international law and that they do not deconstruct every international legal argument, Kennedy's thesis cannot support the conclusion that international law is globally indeterminate.

Both Kennedy and Koskenniemi maintain that recurring international legal arguments are not normative. Argumentative patterns cannot be the force that makes a rule binding, given that they are unable to provide a justification for solutions to legal problems. 402 If, for instance, a diplomat argued that a treaty contains binding provisions because it is based on State consent, Kennedy and Koskenniemi would consider this argument a non-normative outward show. While international legal arguments follow a clear structure, they are, according to the structural indeterminacy thesis, unable to resolve the questions posed in legal cases. ${ }^{403}$ However, we have seen that the majority of international lawyers consider the question of the sources of international law settled despite the theoretical shortcomings of this doctrine.404 Hence they do not question the justifications that Kennedy and Koskenniemi consider unconvincing-in this case, the justification of consent as a ground of legal validity. Since this justification is widely accepted, the UN Charter and the VCLT, in the above example of the Russian invasion, carry normative force. Therefore, patterns of argument are not only an outward show that disguises what is really going on behind the scenes. They are more than an ideological mask. ${ }^{405}$ Recurrent international legal arguments-such as the one that a treaty is binding because it is based on State consent-are thus normative.

While Kennedy and Koskenniemi spend a lot of energy on refuting the objectivity of international law, their own writings-ironically-take the form of an objective treatment of the (in)determinacy question. Placing theory and practice on different, incommensurable levels ${ }^{406}$ allows them to safely ignore the importance of the fact that their structural indeterminacy thesis is not widely shared. Their theory pretends to take precedence over other forms of legal practice and tries to describe the 'real' extent of legal determinacy in international law. To Kennedy and Koskenniemi, it only matters marginally whether their theory is widely accepted; international law is globally

402 KENNEDY, ‘Theses about International Law Discourse', 358; KOSKENNIEMI, From Apology to Utopia, 68-69; VENZKE defines normativity as 'the force that makes a rule binding'. VENZKE, How Interpretation Makes International Law, 6.

403 KENNEDY, 'Theses about International Law Discourse', 358.

404 DIGGELMANN, 'Anmerkungen zu den Unschärfen des völkerrechtlichen Rechtsbegriffs', 383 .

405 PIERRE BOURDIEU, 'The Force of Law: Toward a Sociology of the Juridical Field' (1987) 38 Hastings Law Journal 814, 820.

406 KOSKENNIEMI, 'Letter to the Editors of the Symposium', 360. 
indeterminate because their theory is correct. But who considers it correct? A limited number of scholars, many of whom nevertheless continue to teach and practice in an orthodox manner as if they had never heard of the structural indeterminacy thesis. ${ }^{407}$ However, Kennedy and Koskenniemi claim to write about the entirety of international law, not just about the interpretive community of critically minded international lawyers who are able and willing to deconstruct any international legal argument. They thus seem to presuppose that their theory can settle the question of (in)determinacy in an objective way, i.e. independently of what is inter-subjectively accepted by the members of the diverse interpretive communities in international law. However, given that we do not have access to a standard of truth independent of the set of beliefs that are held by a given interpretive community, 408 the structural indeterminacy thesis can only be considered correct if it is accepted by such a community. This scenario is conceivable. But it would need to be empirically shown that 'we are all crits now'409-not just superficially, but in the sense that in practice we deconstruct every international legal argument as either apologetic or utopian.

\section{II.B.2.iii A Middle Way between Factual Acceptance and Objective Truth?}

Ingo Venzke objects that the assessment of the correctness of legal arguments does not only depend on what our peers let us get away with. ${ }^{410} \mathrm{He}$ criticises the concept of interpretive communities for being unable to explain why we argue with one another about law and life in general: '[i]f everything boils down to a difference in approach, why bother?'411 Venzke thus suggests looking for a middle way between (non-accessible) objective truth and (non-satisfactory) acceptance by one's peers. He calls this middle way a 'valid' legal argument: '[p]lacing emphasis on an argument's validity in the practice of international law suggests that the standards of assessment continue to be those embedded in the argumentative practice itself. They are based on distinct views as to what counts as competent performance.'412 This approach, Venzke affirms, frees us from the conclusion that a correct legal statement is merely what our

\begin{tabular}{ll}
\hline 407 & D’ASPREMONT, 'Martti Koskenniemi, the Mainstream, and Self-Reflectivity', 637-638. \\
\hline 408 & FISH, Is there a Text in this Class?, 365. \\
\hline 409 & $\begin{array}{l}\text { RICHARD L ABEL, 'Book Review: Ideology and Community in the First Wave of Critical } \\
\text { Legal Studies' (2003) 30 Journal of Law and Society 601, 602. }\end{array}$ \\
\hline 410 & $\begin{array}{l}\text { INGO VENKZE, 'What Makes for a Valid Legal Argument' (2014) } 27 \text { Leiden Journal of } \\
\text { International Law 811, 813-815. }\end{array}$ \\
\hline 411 & $\begin{array}{l}\text { Ibid 813; see also HANS-JOACHIM CREMER, 'Völkerrecht - Alles nur Rhetorik?' (2007) 67 } \\
\text { Zeitschrift für ausländisches öffentliches Recht und Völkerrecht 267. }\end{array}$ \\
\hline 412 & VENKZE, ‘What Makes for a Valid Legal Argument', 816 (footnotes omitted).
\end{tabular}


peers will accept. ${ }^{413}$ However, it does not. If the standards of assessment are embedded in the argumentative practice itself, what is considered a 'valid' argument is still solely determined by what is accepted in our interpretive community. Venzke's approach merely introduces a second stage: first, we establish what forms valid arguments must take. In a second step, we test whether a statement about the law is in line with our previously defined standard of validity. We now have to test whether a given legal statement is valid, but what is considered valid is still defined by what is accepted within an interpretive community. Hence Venzke's model does not introduce a middle way between objective truth and acceptance but merely elaborates on how the process of acceptance within an interpretive community may work.

Moreover, Venzke's worry that there is no point in arguing if the only available standard of correctness is defined by interpretive communities can be dispelled. The fact that there are no available standards of correctness other than the ones accepted by interpretive communities does not mean that we do not have good reasons to argue. This would only be the case if we were never certain about what is correct and what is not. But we always have a notion of correctness because we always find ourselves within a structure of beliefs. ${ }^{414}$ Even 'radical sceptics' hold a set of beliefs-in this sense they are not really radical sceptics because this is an unachievable stance. After all, in order to be able to doubt, one's doubts have to be based on assumptions that are themselves immune to doubt. In other words, even doubt has to come from a perspective. Even though this perspective may itself be doubted at a later point, this new doubt would equally come from a perspective which, in turn, has to be immune from doubt. A point from nowhere could only be reached if the mind were cleared of all presuppositions, prejudices, and beliefs. But such a position is unachievable because the mind cannot be separated from the categories of understanding that inform it. Therefore, we always hold a set of beliefs. To believe in something means believing that it is correct ${ }^{415}$-even if the source of correctness is acceptance within one's interpretive community rather than objective truth. When we argue about law and everyday life, we do so because we think that our point of view is correct, independently of the source of correctness. Contrary to what Venzke affirms, we thus have good reasons to continue arguing about what constitutes a correct legal statement even if our standard of correctness stems from what is accepted within an interpretive community. If acceptance within and between

413 Ibid 815.

414 FISH, Is there a Text in this Class?, 364-365.

415 Ibid 360-361. 
interpretive communities is the only available standard of correctness for legal statements, any (in)determinacy thesis should focus on it.

To prevent misunderstandings, I do not argue that an answer to a legal question is correct if it is acceptable in an interpretive community. I submit that acceptance, not acceptability, is the relevant criterion. Acceptability is a central concept in political philosophy: John Rawls, for instance, tried to come up with a theory of what would be acceptable principles of justice. ${ }^{416}$ The notion of acceptance, in contrast, is far from such romantic ideas. A legal solution can be accepted even though it may be utterly unacceptable to some who, nevertheless, have to accept it. Acceptance may come about through power, whereas acceptability is based on the idea of genuine agreement. I will return to the question of how acceptance may be reached in Section II.B.3.

A further objection raised by Venzke against the model of interpretive communities is that it cannot explain how interpretive angles could change. 417 How can change occur if a community is only constrained by its own assumptions and interpretive strategies? How can an individual whose views on the world are limited by the standards of an interpretive community take note of anything that is not captured by those standards? At first sight, only two unconvincing answers seem to be available: either individuals can take objects into account that are not presupposed by the standards of their interpretive communities, or individuals remains trapped within the assumptions of their communities. The first alternative empties the concept of an interpretive community, which claims that it cannot be constrained by independent facts. The second option would imply the obviously wrong conclusion that nobody has ever changed his or her mind. ${ }^{418}$ However, these two options are based on a too rigid understanding of interpretive communities. Agood example of how change can occur is the impact of Koskenniemi's From Apology to Utopia on international law. Sahib Singh writes that the book changed what 'is possible to say within the discipline and how it is possible to say it.' ${ }^{19}$ How could a book with a radically new approach change anything within the interpretive communities of international law? If interpretive communities only allowed the consideration of what is already a part of their assumptions, the structural indeterminacy thesis would have been completely ignored by the majority of legal scholars. The reason why it has not been ignored is that From Apology to Utopia relies on some assumptions that were not challenged at the time.

\footnotetext{
416 JOHN RAWLS, A Theory of Justice (first published 1971, 1999 Harvard University Press).

417 VENKZE, 'What Makes for a Valid Legal Argument', 813.

418 FISH, Doing What Comes Naturally, 143-144.

419 SAHIB SINGH, 'Koskenniemi's Images of the International Lawyer' (2016) 29 Leiden Journal of International Law 699, 700.
} 
Koskenniemi's thesis operated on what was already partially accepted by most international lawyers. From this common basis, it was possible to convince some international lawyers who were not members in one of Koskenniemi's own interpretive communities. Change in interpretive communities thus occurs from the inside, not from the outside. Kennedy and Koskenniemi share with 'mainstream' international lawyers 420 the belief that they are engaged in figuring out the extent of determinacy of international law. They agree, amongst other points, that it is a crucial question whether international law can constrain judges when deciding cases. This common purpose of their respective research agendas makes it possible for mainstream international lawyers to look at the structural indeterminacy thesis from within their own interpretive communities. Persuasion can occur when one party to the discussion refers to a purpose other parties also acknowledge and argues that her own route is the only one leading there. If another party is persuaded, his understanding of what is internal to the discipline will have changed, not by imposition from the outside but by building on assumptions that are internal to their interpretive community. ${ }^{421}$ Singh is therefore right to argue that From Apology to Utopia has changed what can be said within the discipline of international law, even though his statement is exaggerated as the book's impact has been limited to only a few scholars while the majority has returned to business as usual.422

In this section, I have argued that the structural indeterminacy thesis cannot be upheld. Instead of depending on a marginalised theory, the extent of legal determinacy depends on what is accepted by an interpretive community. Because the structural indeterminacy thesis put forward by Kennedy and Koskenniemi is not widely accepted within the professional communities of international law, its conclusion has to be rejected. While this and the preceding section have focused on the extent of legal determinacy within interpretive communities, the following one will address the relations between such communities. Furthermore, it will suggest in more detail how (in)determinacy theses should be framed.

\section{II.B.3 A New Framing of (In)determinacy Theses}

If meanings are not waiting for their discovery within objects of interpretation but are conferred on them by interpretive communities, an analysis of the extent of determinacy cannot be based on objective properties of legal

420 The advantages and disadvantages of using the notion of 'mainstream' is discussed in D'ASPREMONT, 'Martti Koskenniemi, the Mainstream, and Self-Reflectivity', 628.

421 FISH, Doing What Comes Naturally, 147-148; FISH, Is There a Text in This Class?, 369.

422 D’ASPREMONT, 'Martti Koskenniemi, the Mainstream, and Self-Reflectivity', 638. 
texts or facts but must instead focus on what the relevant interpretive communities make of them. Yet, most (in)determinacy theses focus on the properties of legal texts or the inherent difficulties of fact-ascertainment: Jerome Frank argued that many legal questions are indeterminate due to the uncertainties arising from fact-ascertainment. ${ }^{423}$ Directly influenced by the American legal realists, Myres McDougal contended that law is indeterminate where it contains conflicting principles. ${ }^{424}$ H.L.A. Hart and Hans Kelsen both maintained that legal indeterminacies arise due to the uncertainties of language. 425 Such indeterminacy theses, while illuminating in many respects, involve conclusions that are too wide; whether law is indeterminate or not is not a function of how inherently uncertain the facts are, whether legal principles really conflict, or to what extent a legal norm is truly vague. Instead, the indeterminacy of law depends on the meanings conferred on facts and legal texts by interpretive communities, and on how conflicts between such interpretive communities are resolved. Frank, McDougal, Hart, and Kelsen all tried to make statements about the extent of determinacy of (international) law generallywithout looking at how different interpretive communities perceive the law and whose views prevail. The questions these scholars considered relevant were: do norms on the same level of hierarchy conflict? Are legal texts formulated openly? As has been seen, such (in)determinacy theses involve one of two possible mistakes. The first one is to assume that legal texts can be grasped independently of the practice in which they are interpreted; that legal norms exist in a pure state in which they have not yet been interpreted. This dualism between legal norms and their interpretation makes it possible to ask about the constraining force inherent to such norms. If there is a constraining force in law, it is located within non-interpreted legal norms. Thus the question about the extent of legal determinacy becomes equivalent to the question about the constraining force of such norms. The second possible mistake mentioned above is to assume that all jurists perceive the law in a similar way. However, some interpretive communities may see an irreconcilable conflict of norms where others perceive the same case to be straightforward. In order to steer clear of both of these mistaken assumptions and explore more productive avenues instead, research on the extent of legal determinacy should not focus on objects of interpretation but on the meanings that are conferred on them by particular interpretive communities.

423 FRANK, “'Short of Sickness and Death"', 547; FRANK, 'Both Ends Against the Middle', 23.

424 LASSWELL and MCDOUGAL, 'Legal Education and Public Policy', 236; LASSWELL and MCDOUGAL referred to the legal realist BENJAMIN CARDOZO on this point.

425 HART, The Concept of Law, 126; HANS KELSEN, Legal Technique in International Law, 17. 
David Kennedy and Martti Koskenniemi defend a different type of indeterminacy thesis. They do not argue that international law is indeterminate because of the properties of valid legal norms. How legal norms are formulated, and whether they conflict or not, is of secondary importance to them. Instead, international law is deemed indeterminate because no ground of legal validity can be found that would not contradict the liberal core premises of international law. Thus Kennedy and Koskenniemi's structural indeterminacy thesis focuses not on valid legal norms but on the grounds of legal validity. As argued above, the structural indeterminacy thesis is based on a false dichotomy between theory and practice. ${ }^{426}$ In what follows, I will argue that not only the dichotomy between theory and practice but also the dualism between legal norms and their interpretation should be abandoned. Doing so will make it possible to take practice seriously.

\section{II.B.3.i The Impossible Dualism between Norms and Their Interpretation}

According to legal positivism, valid legal norms are established by relying on formal pedigrees. The normativity of rules is explained by tracing them to a set of formal sources. ${ }^{427}$ Regardless of the increasing heterogeneity in international legal scholarship, this traditional approach is still the most widespread one in international legal education and practice. ${ }^{428}$ Leslie Green succinctly defines legal positivism as 'the thesis that the existence and content of law depends on social facts and not on its merits.' 429 Contrary to a widely believed myth, legal positivists are not committed to a particular method of interpretation. Regarding the interpretation of law, they are merely committed to the view that a law can only be interpreted if there is a valid law in the first place. ${ }^{430}$ Legal positivism deals with the existence and content of law, not with its interpretation. Kelsen even completely separated legal science from interpretation. 431 This limitation of legal positivism's scope presupposes that valid legal norms can be meaningfully studied in a non-interpreted state. For present purposes, I am only interested in the implications such a presupposition has for the analysis of the extent of legal determinacy. Moreover, my

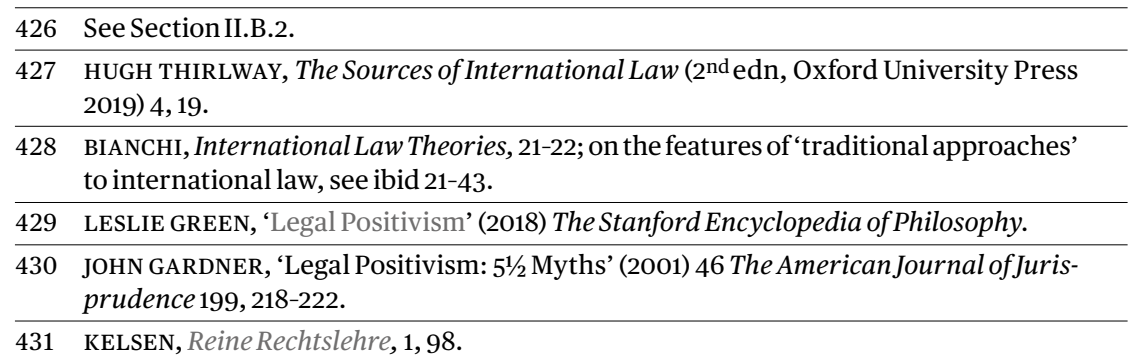


interest is not in legal positivism as such but in the structure of (in)determinacy theses, which seems to be influenced by this dominant legal theory. I will not argue that the positivist dichotomy between non-interpreted legal norms and their interpretation is problematic everywhere and at all times. ${ }^{432}$ My argument is merely that in the context of studying the constraining force of law, it is detrimental to assume such a dichotomy. Moreover, the dualism between legal norms and their interpretation is not an idea limited to legal positivism. However, given that legal positivism remains the most widespread approach in legal education and practice, ${ }^{433}$ my-empirically speculativehypothesis is that it has contributed to the common assumption that norms can be understood in a not-yet-interpreted state. The ideas of legal positivists thus serve as a useful point of departure for an argument that challenges the dichotomy between norms and their interpretation.

I have argued that meanings are not found within objects of interpretation, such as legal texts, but conferred on them by interpretive communities. If there is no purely textualist meaning, the separation of non-interpreted norms and their interpretation is not viable. If meaning is only a product of practice, trying to separate norms from that practice strips them of their meaning. I will develop this point by referring to the widespread conceptualisation of international law as a language. This will feed into the argument that international law-just like natural languages-is not dependent on a background scheme in order to acquire meaning. Hence the dualism between the background scheme (legal norms) and its execution (legal interpretation) collapses.

\section{II.B.3.i.a. There Is No Background Scheme in Law and Language}

Ingo Venzke identifies three common ways of referring to international law as a language and their underlying linguistic assumptions. ${ }^{434}$ In the first use of the metaphor, the language of international law functions as a defence against the powerful and strengthens purportedly universal values. Rosalyn Higgins pointed out that the UN supports promoting 'a common language of international law among the peoples of the United Nations and a universal culture shared by all nations that is conducive to peace, justice, and the rule of law.' 435 In this use of the metaphor of international law as a language, interpretations

\footnotetext{
432 It is a different discussion, for instance, whether separating legal norms from their interpretation has didactical advantages.

433 BIANCHI, International Law Theories, 21-22.

434 VENZKE, 'Is Interpretation in International Law a Game?’.

435 ROSALYN HIGGINS, 'Teaching and Practicing International Law in a Global Environment: Toward a Common Language of International Law' (2010) 104 American Society of International Law Proceedings 196, 200.
} 
are constrained and supported by language. In linguistics, Ferdinand de Saussure's distinction between language (langue) and speaking (parole) ${ }^{436}$ corresponds to this view of legal interpretation: '[l]anguage is a system of signs', which is different from acts of speaking. ${ }^{437}$ Language constrains and structures speaking. It forms a stable background scheme against which speaking can be evaluated. According to Saussure, language thus functions like a game of chess; a move on the chessboard does not change the rules of the game. If international law is understood as a language under such a conception, this means that legal interpretations do not change international law. Moving the king two squares on the chessboard does not change the rule that the king can only be moved exactly one square. Similarly, some legal interpretations are prohibited by international law, and would remain so even if they regularly occurred. ${ }^{438}$ Under such a conception, interpretation is neatly distinguished from the rules of international law. An international lawyer holding such a view of international law and its interpretation is likely to approach the question of (in)determinacy in a similar way: if the rules of international law exist (and thus contain meaning) independently of their interpretation, the constraining force of international law can be studied solely by looking at the rules themselves. Since practice does not matter for the production of meaning, the determining force of international law can be analysed by focusing on fixed international legal rules. The distinction between the background scheme (the rules of language and of law, respectively) and its execution (speaking; the interpretation of law) is upheld in this first approach. 439

The second use of the metaphor puts less emphasis on the stabilising force of the language of international law. While it does not necessarily strengthen a set of values, it is held to provide a common idiom for conflicting parties. International law may not directly lead to peace, justice, and the rule of law, but at least it constitutes a channel for communication. Speaking the language of international law means demonstrating one's technical skill as a legal professional. ${ }^{440}$ Principles of international law 'serve as a language in which states and other relevant actors exchange views on the specific problems of difficult

436 FERDINAND DE SAUSSURE, Course in General Linguistics (first published 1916, Philosophical Library 1965) 13.

437 Ibid 16.

438 Ibid 88. SAUSSURE compares language and speaking to a symphony and its performance. If musicians make a mistake, this leaves the symphony unchanged. Musicians cannot make new interpretations of the symphony; they can only play it either correctly or wrongly. Ibid 18 .

439 VENZKE, 'Is Interpretation in International Law a Game?', 353-356.

440 Ibid 356-357. 
cases.' 441 The grammar of international law allows international lawyers to communicate while other disciplines remain divided. ${ }^{442}$ This view of international law finds support in the work of Noam Chomsky, who maintains that language is to be understood as a competence, i.e. an 'underlying system of rules'. ${ }^{443}$ Saussure and Chomsky share the idea that a linguistic background scheme orders the actual performance of speaking. ${ }^{444}$ Both models converge on the idea that a 'wrong' legal interpretation does not change the background scheme of international law. In this second model, international law brings together opponents who share the same competence. This shared competence is what stabilises interpretation in international law. ${ }^{445}$ Hence the second approach also upholds the distinction between a background scheme and its execution.

The stabilising force of the language of international law is lost in the third approach identified by Venzke. Instead, international law is thought of as a battle zone on which actors try to find acceptance for their claims of (il)legality. What matters is not competence in a linguistic background scheme but actual performance. ${ }^{446}$ At times, the language of international law may be 'comforting', ${ }^{447}$ whereas at others, it serves as a 'weapon'. ${ }^{448}$ The dualism between 'the law' and its execution (i.e. its interpretation) is rejected. ${ }^{449}$ Under such a conception, it does not make sense to analyse the extent of legal determinacy by only taking legal texts into consideration. Legal texts, such as international conventions and case-law, do not work as a constraining background scheme but can only be grasped through the practice of an interpretive community that confers meanings on them. When and how legal texts are constraining or not is decided in semantic struggles in the battle zone of international law. Within a particular community, an academic publication may well have greater constraining force than an international treaty, even though

\begin{tabular}{|c|c|}
\hline 441 & $\begin{array}{l}\text { GEORG NOLTE, ‘Multipurpose Self-Defence, Proportionality Disoriented: A Response } \\
\text { to David Kretzmer' (2013) } 24 \text { European Journal of International Law 283, } 290 .\end{array}$ \\
\hline 442 & SCHACHTER, ‘The Invisible College of International Lawyers’, 222. \\
\hline 443 & NOAM CHOMSKY, Aspects of the Theory of Syntax (MIT Press 1965) 4. \\
\hline 444 & Ibid; SAUSSURE, Course in General Linguistics, 13. \\
\hline 445 & VENZKE, ‘Is Interpretation in International Law a Game?’, 357-359. \\
\hline 446 & $\begin{array}{l}\text { Ibid 359-360; such an approach is mapped out by VENZKE, How Interpretation Makes } \\
\text { International Law, 37-64. }\end{array}$ \\
\hline 447 & $\begin{array}{l}\text { CHRISTINE SCHWÖBEL, ‘The Comfort of International Criminal Law' (2013) } 24 \text { Lawand } \\
\text { Critique } 169,170 .\end{array}$ \\
\hline 448 & $\begin{array}{l}\text { MICHELLE BURGIS, 'Discourses of Division: Law, Politics and the ICJ Advisory Opinion } \\
\text { on the Legal Consequences of the Construction of a Wall in the Occupied Palestinian } \\
\text { Territory' (2008) } 7 \text { Chinese Journal of International Law 33, } 38 \text {. }\end{array}$ \\
\hline
\end{tabular}


pursuant to Article 38(1)(d) ICJ Statute, scholarly publications serve only as 'subsidiary means for the determination of rules of law'. When pondering the extent of legal determinacy, one cannot meaningfully first look for a background scheme ('what is the law?') and then ask how constraining it is. There is nothing inherently constraining about the background scheme, which is why it is unhelpful to even conceptualise (in)determinacy as a matter of the relation between a background scheme and its execution. Given that I have argued that meanings are not inherent to legal texts or facts but conferred on them by people who are members of different interpretive communities, I follow the third approach; just as in language, there is no dualism between a background scheme and its execution in law, either.

This dualism has indeed been challenged by critics. John Austin rejected the dualism between language and speech, as defended by Saussure, or between competence and performance, as posited by Chomsky. Every act of speaking, according to Austin, is also an act of creation. It is not possible to merely describe something without also contributing to its interpretation; stating 'this is an act of self-defence' is not only a factual description but contributes to interpreting the situation as well. Thereby, a statement about (international) law contributes to making it. ${ }^{450}$ Yet, jurists 'succumb to their own timorous fiction, that a statement of "the law" is a statement of fact.' 451 Whether a speech act, such as baptising a child, succeeds in performing what the speaker wants to achieve does not depend on a background scheme that could provide a standard of correctness. Instead, the only standard for evaluating the success of a speech act is its context and the social conventions of the community in which it is evaluated. ${ }^{452}$ Equally, the success of the statement 'this is an act of self-defence' does not depend on a standard of correctness inherent to Article 51 UN Charter but depends on whether such an utterance is accepted in a given community.

Pierre Bourdieu expanded on the critique of the dualism between a background scheme and its execution as defended by Saussure and Chomsky. This model, according to Bourdieu, pretends that scientists who are familiar with the background scheme can have access to the objective meaning of practices. ${ }^{453}$ However, the meaning of a message can only be determined within a

450 JOHn AUSTIN, How to Do Things with Words (Oxford University Press 1962) 72; VENZKE, 'Is Interpretation in International Law a Game?', 363.

451 AUSTIN, How to Do Things with Words, 4, fn 2.

452 JOHn AUSTIN, Philosophical Papers (Oxford University Press 1961) 220, 235; see also VENZKE, 'Is Interpretation in International Law a Game?', 363.

453 'It is this primeval distinction between language (langue) and its realization in speech (parole), that is, in practice and in history, which is at the root of the inability of struc- 
given field, not from outside of it. 454 Therefore, 'grammaticality is not the necessary and sufficient condition of the production of meaning, as Chomsky (...) might lead us to believe.' 455 Instead of focusing on a background scheme, language can only be understood by looking at the way it is practised. ${ }^{456} \mathrm{Cor}$ respondingly, Bourdieu also supported the view of law as a battle zone rather than endorsing a conception of law that separates a background scheme from its execution: '(...) as with religious, philosophical, or literary texts, control of the legal text is the prize to be won in interpretive struggles.' 457 Thus for Bourdieu, the focus ought to be not on the legal text but on the practice by which control over it can be gained. What is legally acceptable is not determined by a background scheme but by those who win the interpretive struggle about the law's meaning.

Chomsky's model, which separates competence and performance, has been called a 'Garden of Eden view' by Dell Hymes. ${ }^{458}$ He criticised Chomsky's approach for neglecting sociocultural features by focusing on perfect competence and homogenous speech communities. ${ }^{459}$ Rather than focusing on the stable background scheme of linguistic competence, the focus should be on actual performance according to Hymes. In particular, the sociocultural features that influence how people learn to speak and how they actually speak need to be understood. ${ }^{460}$ Communication cannot adequately be captured by studying a background scheme, namely a common language. 461 Instead, the different usages of languages ought to be studied by looking at speech communities:

Membership in a speech community consists in sharing one or more of its ways of speaking-that is, not in knowledge of speech style (or any other purely linguistic entity, such as a language) alone, but in terms of

turalism to think the relation between two entities other than as the model and its execution, essence and existence, and which amounts to putting the scientist, keeper of the model, in the position of a Leibnizian God to whom the objective meaning of practices is given.' PIERRE BOURDIEU and LOÏCJ D WACQUANT, An Invitation to Reflexive Sociology (University of Chicago Press 1992) 142.

\begin{tabular}{ll}
\hline 454 & Ibid 149. \\
\hline 455 & Ibid 142. \\
\hline 456 & Ibid 149. \\
\hline 457 & BOURDIEU, ‘The Force of Law', 818. \\
\hline 458 & $\begin{array}{l}\text { DELL HYMES, 'On Communicative Competence' in John B Pride and Janet Holmes } \\
\text { (eds), Sociolinguistics: Selected Readings (Penguin 1972) 55. }\end{array}$ \\
\hline $459 \quad$ Ibid 57. \\
\hline 460 & Ibid 55. \\
\hline 461 & $\begin{array}{l}\text { DELL HYMES, 'Speech and Language: On the Origins and Foundations of Inequality } \\
\text { among Speakers' (1973) 102 Dædalus 59, 65; see also VENZKE, 'Is Interpretation in Inter- } \\
\text { national Law a Game?’, 363. }\end{array}$
\end{tabular}


knowledge of appropriate use as well. There are rules of use without which rules of syntax are useless. ${ }^{462}$

While Hymes shifted the focus from competence to actual performance, it is worth noting that he referred to 'rules of use' that are shared by speech communities. He thus moved the focal point away from the rules of the background scheme, only to emphasise the importance of common rules in speech communities. Hence, he did not get rid of rules.

A similar move is made by John Searle. Unlike Saussure and Chomsky, Searle takes speaking-not language or competence-to be the genuine object of linguistic analysis. Following Austin, he rejects the dualism between a background scheme and its execution. Speaking is never just descriptive but always an act of creation. ${ }^{463}$ Searle asks how the claims that 'oculist' means eye doctor or that 'woman' means adult human female can be verified. ${ }^{464}$ Like Austin, Searle argues that the success of such claims depends on shared background conventions. ${ }^{465}$ More precisely, '[s]peaking a language is engaging in a (highly complex) rule-governed form of behavior. To learn and master a language is (inter alia) to learn and to have mastered these rules. ${ }^{366}$ Hence Searle, similarly to Hymes, reintroduces rules despite focusing on the actual practice of speaking rather than on a background scheme. While Saussure and Chomsky focused on how language and competence figure as the rules for actual speech, Hymes and Searle emphasise the importance of rules on the level of speaking. ${ }^{467}$

If practice is not dependent on a background scheme, how can we understand practice if not as a set of rules? I have argued in this sub-section that practice is not dependent on a background scheme (such as the rules of language or of international law). In what follows, I will argue that the reintroduction of rules on the level of practice can be avoided; the practice of international law should not be understood as being based on a set of rules.

462 HYMES, 'Speech and Language', 67.

463 AUSTIN, How to Do Things with Words, 72; JOHN R SEARLE, Speech Acts: An Essay in the Philosophy of Language (Cambridge University Press 1969) 68; SYBILLE KRÄMER, 'Sprache und Sprechen oder: Wie sinnvoll ist die Unterscheidung zwischen einem Schema und seinem Gebrauch?' in Sybille Krämer and Ekkehard König (eds), Gibt es eine Sprache hinter dem Sprechen? (Suhrkamp 2002) 101.

464 SEARLE, Speech Acts, 12.

465 JOHN R SEARLE, Making the Social World (Oxford University Press 2010) 155-160.

466 SEARLE, Speech Acts, 12; see also ibid, 13-15.

467 KRÄMER, 'Sprache und Sprechen', 104; see also VENZKE, 'Is Interpretation in International Law a Game?', 364; VALERIO PRIULI, Das Kosovo-Verfahren des internationalen Gerichtshofs: eine argumentationstheoretische Untersuchung (Duncker \& Humblot 2016) 74-75. 


\section{II.B.3.i.b. Breaking out of the Infinite Regress of Rules}

Throughout Section II.B.1, I have argued that legal meanings are created within interpretive communities. Members of an interpretive community share the same background conventions. The so far unanswered question arises how these background conventions are to be understood. Owen Fiss submits that legal interpretations are constrained by a set of rules that are accepted as authoritative within an interpretive community. ${ }^{468}$ Fiss' approach resembles the one I defend here, with the important exception that I do not agree that the background conventions of interpretive communities should be understood as a set of rules. I argue-in line with the views of Austin, Bourdieu, Hymes, and Searle-that the dualism between a background scheme and its execution à la Saussure and Chomsky should be abandoned. However, it is crucial not to reintroduce such a dualism. Conceiving of the background conventions of interpretive communities as a set of rules-as done by Hymes, Searle, and Fiss-is susceptible to this very critique. If the background conventions of an interpretive community amount to a set of rules, we are again faced with a background scheme (a set of rules) and its execution (the interpretation of these rules). Hence, we come full circle: if we uphold the dualism between legal rules and their interpretation, we then ask to what extent these rules constrain interpretation. If we decide to focus on legal practice instead, but hold that this practice is governed by a set of rules that are accepted by a given interpretive community, we just encounter the same question about the constraining force of rules again. ${ }^{469}$

Conceptualising the background conventions of interpretive communities as a set of rules is dissatisfactory not only because we end up with the same question we started with, but also for an additional reason. Searle suggests that knowing how to play baseball is based on having internalised a set of rules and that, by analogy, this also applies to knowledge of linguistic characterisations. Both in baseball and in language, mastery of the rules can dictate correct answers as long as the rules are 'determinate enough', which-as Searle hastens to add-is not always the case. ${ }^{470}$ I have argued why the interpretive rules codified in the VCLT cannot ultimately constrain interpretation. ${ }^{471}$ A similar argument is put forward here on a more general level. For rules to be able to actually constrain an interpreter, or to dictate the actions of a baseball

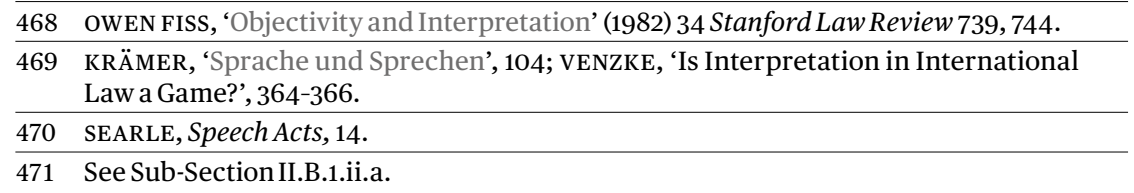


player, at least some rules would need to be evident without interpretation. If an interpretive rule needs to be interpreted as well, so does the rule that interprets the interpretive rule, etc. In this way, we would end up with an infinite regress of rules that cannot constrain; turtles all the way down. If rules are constraining, either 1) at some point there needs to be a rule that clearly communicates its content to any observer or 2) something other than rules works as the constraining force.

Option 1) is excluded because there cannot be a rule that communicates its unambiguous meaning to any observer if there is no purely textualist position. Meanings do not hibernate in rules, waiting to be awakened, but are conferred on them. The problem with Searle's approach is that isolated rules, i.e. rules in their form as non-interpreted text, are indeterminate. Rules are never not-already-interpreted, $\mathbf{4 7 2}$ which is why we cannot encounter any rule that is waiting for an interpreter to confer meaning on it. However, we can analytically comprehend why an isolated rule cannot explain on its own what ought to be said in language or what ought to be done in sports. The impression of a rule 'containing' meaning is merely an illusion. This illusion arises because, in many cases, everyone we have ever heard of regularly confers the same meaning on a rule (and on the concepts it relies on). Such a stable meaning of a rule should, however, not obscure the fact that this stability stems from our consensus about what the rule means, rather than from its essential qualities. For most practical purposes, this distinction does not matter; in daily life, it is next to irrelevant whether a rule has inherent meaning or whether a particular community regularly confers the same meaning on it. For an analysis of the constraining force of law, however, it is crucial exactly what the source of meaning of legal norms is.

Since the first option must be rejected, we are left with option 2). If background conventions of interpretive communities cannot be conceptualised as a set of rules, how are they to be understood instead? How do background conventions constrain (legal) interpretation if they are something different from rules? The difficulty lies in the fact that we can never perceive rules in a non-interpreted form. We cannot read rules in their unsullied state and then proceed to interpret them. Every rule that comes to our attention is already interpreted in the very process of hearing or reading it. ${ }^{473}$ Hence, while it is possible to describe everything a judge or sportsperson does in terms of rules, this does not signify that the interpreted meaning stems from the rule itself. 474

472 FISH, Doing What Comes Naturally, 122.

473 Ibid.

$474 \quad$ Ibid 124. 
Instead, it stems from the background conventions that we accept. When we think of a sport or of international law, we have an understanding, gained through professional training and practical experience, of the general purpose of the enterprise. Rules can only be understood in light of the practice they are supposed to order. Interpreters are constrained by assumptions and categories of understanding that are embodied in this very practice. 475 Hence background conventions of interpretive communities emanate from practical experience rather than from exposure to a set of rules.

Such an understanding of the determining force of law also dispels a widespread concern about legal interpretation. Those who are concerned that interpretation is unprincipled because interpreters are not sufficiently constrained by rules that limit the possible meanings of legal texts do not need to worry. ${ }^{476}$ The dreaded state in which interpreters face no constraints whatsoever in dealing with a text does not exist. It collapses together with the dualism between the background scheme and its execution. If the legal text (the background scheme) and its interpretation (the execution of the background scheme) cannot be separated, there is no need to be concerned about bending the former. Since a text cannot be perceived in a non-interpreted state, interpretation has already happened as soon as it gets a reader's attention. Readers are always already constrained by the background conventions of their interpretive communities, even if this does not mean that they are constrained by any rules. A shared understanding of what international law is for, as well as the professional training one has undergone, among other factors, will preselect a certain kind of reading-and thereby constrain the set of readings that are likely in the first place. Interpretation is never free but always constrained by the standards, norms, and criteria of evidence that are shared within an interpretive community. Since everybody always argues from a certain point of view, 477 nobody enjoys the freedom of being an unconstrained reader. The indeterminacy of legal texts 'as such', if it were possible to consider them separately from the way they are perceived, does not mean that law is indeterminate. If certain background conventions are shared, law can be determinate in what are seen as 'easy cases'.

Not only jurists, Thomas Kuhn argued, but also scientists 'never learn concepts, laws, and theories in the abstract and by themselves. Instead, these intellectual tools are from the start encountered in a historically and pedagogically

\footnotetext{
$475 \quad$ Ibid 127.

476 Ibid 133; such concerns are expressed in OWEN FISs, 'Objectivity and Interpretation', 740 .

477 I argued that radical scepticism is an impossible position, given that one's doubts would have to be free from doubt, in Sub-Section II.B.2.iii.
} 
prior unit that displays them with and through their applications.' 478 Scientific paradigms cannot be reduced to a set of rules. ${ }^{479}$ Therefore a research tradition cannot be understood in terms of a body of rules either. ${ }^{480}$ If, for instance, someone is confronted with the rule of mechanics that 'actual descent equals potential ascent', he cannot make sense of it unless he has some prior knowledge about certain situations as they occur in nature. ${ }^{481}$ This kind of knowledge, however, cannot be learned by verbal means alone. Instead, it stems from observing concrete examples as they work in practice. Verbal statements of a rule, without prior knowledge of the practice it is supposed to order, are 'virtually impotent'. ${ }^{482}$ Scientists are nevertheless restricted to a particular scientific tradition as they rely on tacit knowledge that cannot be articulated explicitly but is acquired through practice. ${ }^{483}$ The identification of a set of rules is not necessary for a paradigm to guide research. Rather,

[s]cientists work from models acquired through education and through subsequent exposure to the literature often without quite knowing or needing to know what characteristics have given these models the status of community paradigms. And because they do so, they need no full set of rules. ${ }^{484}$

As already noted above, Wittgenstein argued that attempting to explain what a rule means by relying on another rule leads to an infinite regress-rules all the way down. 485 This argument, however, only clarifies why we need to find an alternative to rules, without offering any clues as for what this alternative may look like. The alternative is sketched by Wittgenstein in his discussion on the common characteristics of words. He rejects the view that words like

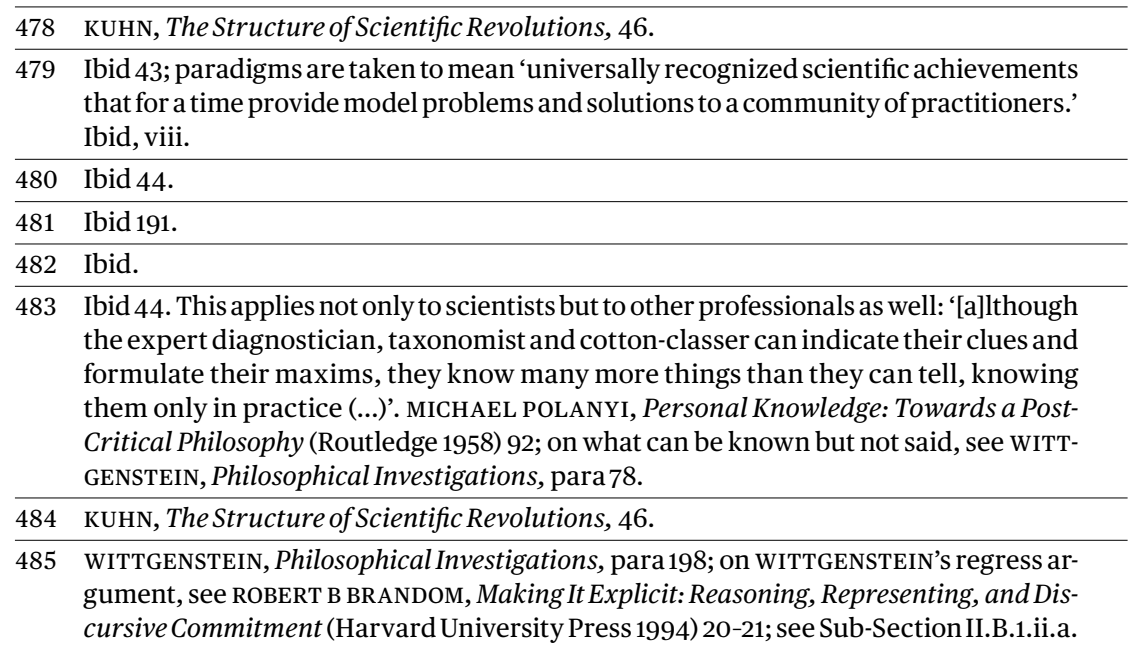


'leaf' or 'game' can be grasped by formulating a rule that captures all leaves or all games, respectively. Instead of having common characteristics that would allow us to formulate a rule, all games are related to each other in the sense that some attributes are shared by a number-but not all-things we call 'games'. ${ }^{486}$ We nevertheless use these words because we recognise 'family resemblances' among them. If we call something a 'game', we do so because it has some relationship with several of the things we have previously called games. We extend our concept of a game by spinning it like a thread, adding fibre by fibre. The strength of the thread does not depend on a long fibre that runs through the entire thread but is made up of the partial overlapping of many short fibres. ${ }^{487}$ The fact that we cannot define an exact boundary for such words does not bar us from considering them useful: '[w] hat still counts as a game and what no longer does? Can you give the boundary? No. You can draw one; for none has so far been drawn. (But that never troubled you before when you used the word "game".)' 488

In Section II.A.2, I have argued that even though we cannot draw sharp boundaries around vague expressions (how many grains of sand does a 'beach' contain?), this does not mean that there are no clear cases to which we are certain that vague expressions apply (the Copacabana clearly is a beach). That discussion seemed to lead to an unsatisfactory conclusion-surely we should be able to draw a line between a heap of sand and a proper beach somewhere? In other words, some readers may have felt that some rule must exist that can distinguish a beach from a heap of sand. After the discussion in the present section, however, it should become clear that our ability to distinguish the Copacabana from a heap of sand is not based on a rule but on 'family resemblances' of which we gain knowledge through practical experience. This insight should inform how jurists decide on whether certain conduct is 'reasonable', 'just', 'proportionate', 'necessary', etc. Not every concept needs to be justified as falling under a rule; it will never be possible to come up with an airtight rule for what kind of reaction is 'proportionate' when acting in selfdefence in accordance with Article 51 UN Charter. However, there will be clear cases of proportionate and disproportionate uses of force. Based on our experience of what constitutes self-defence and what exceeds it, we will be able to recognise family resemblances when classifying certain behaviour. If international lawyers feel compelled to frame the proportionality of self-defence as falling under a determinate rule, they become susceptible to criticism because

486 Wittgenstein, Philosophical Investigations, paras 65-78.

487 Ibid para 67.

488 Ibid para 68. 
it will always be possible to come up with an example contradicting the rule. Such criticism, however, cannot challenge a certain decision by showing that one example could not be subsumed under the rule. In this sense, jurists should not overrate the importance of rules for justifying and criticising (judicial) decisions.

The lack of success of the search for a rule delimiting a (legal) conceptthe Wittgensteinian fibre that runs through the whole length of the threaddoes not lead to uncertainty. We are quite sure what we mean when we refer to games because we have an extensive database of phenomena that qualify as games. Similarly, the fact that we struggle to find a rule that defines 'selfdefence', 'inhuman treatment', or a 'civilian' does not imply that we can never be sure when to apply these words. 489 As we have read and heard about many instances that qualify as a 'civilian', we are quite sure how to classify a new situation even though we may be unable to formulate a general rule that would conclusively define the concept. Our certainty stems from being familiar with a professional practice, not from our knowledge of a set of rules. Conceptualising the background conventions of interpretive communities as stemming from practical experience rather than from the knowledge of rules allows us to break out of the infinite regress which so far seemed inevitable. The insight that practice does not depend on anything else to determine (in)correct applications of legal concepts helps to understand normativity in international law as a function of its practice.

\section{II.B.3.ii Normativity Arising from the Practice of International Law}

Wittgenstein's explanation of how we can understand concepts like 'leaf' or 'self-defence' without relying on rules underlines the importance of past usages. This makes it possible to conceptualise the background conventions of interpretive communities as being based on practical experience instead of falling back on an infinite regress of rules. An account of how meanings are conferred on legal texts within interpretive communities, however, does not yet enable us to comprehend how different interpretive communities interact. Given that every individual is a member of a particular if not unique set of interpretive communities, the reference group relevant to a legal question will

489 This insight reduces the importance of some academic discussions in law. For instance, the controversy about whether human rights can be precisely defined is much less relevant than its participants seem to assume. Human rights, just like any other concept, cannot be exhaustively defined by a set of rules. This, however, does not mean that we cannot tell with confidence whether certain conduct amounts to a violation of human rights law or not. For numerous attempts to define human rights, and critiques thereof, see Rowan Cruft, S Matthew Liao, and Massimo Renzo (eds), Philosophical Foundations of Human Rights (Oxford University Press 2015). 
always encompass people who perceive the law differently. The process of conferring meaning on legal texts can be studied in two steps: first, how do individuals read a legal text? I have argued that this is a function of the background conventions of the interpretive communities an individual is a member of. In a second step, it should be analysed how individuals, who are members of different interpretive communities, come to agree regarding the answer to a legal question. This is the main subject of the present sub-section.

Robert Brandom shares the pragmatist thesis that concepts (including legal norms) can have no content apart from the one that is conferred on them through their usage. ${ }^{490}$ His model helps to better understand how practice alone can generate normativity without relying on a background model, i.e. on a set of determinate rules. Put differently, if there is no meaning waiting to be discovered in legal norms that is independent of their usage in a particular community, the need to reconceptualise normativity in international law arises.

When applying a concept, according to Brandom, we undertake commitments towards others to use certain expressions. ${ }^{491}$ The contents of these concepts are not fixed prior to being applied: '[c]onceptual content arises out of the process of applying concepts-the determinate content of concepts is unintelligible apart from the determination of that content, the process of determining it.' 492 The fact that concepts-and hence legal norms-have no fixed meaning other than the one which is conferred on them through their usage explains why individuals can only commit themselves to the use of a concept but not to its content. If Lucy commits herself to using a certain expression, this does not mean that she has committed herself to the content of that concept. By committing herself, Lucy makes the concept binding for herself without defining what would be an (in)correct application of the concept. If the endorsement of a rule or norm already settled all its possible applications, then Lucy could bind herself through a commitment. The challenge is that she is unable to do so if semantic pragmatism is right that the content of a rule cannot be grasped independently of its usage. In other words, committing oneself to the content of a concept in advance of an actual application is not possible because the content of said concept is only shaped in the process of

490 ROBERT B BRANDOM, 'Some Pragmatist Themes in Hegel's Idealism: Negotiation and Administration in Hegel's Account of the Structure and Content of Conceptual Norms' (1999) 7 European Journal of Philosophy 164, 164; see also ROBERT B BRANDOM, 'The Pragmatist Enlightenment (and its Problematic Semantics)' (2004) 12 EuropeanJournal of Philosophy1.

491 BRANDOM, 'Some Pragmatist Themes in Hegel's Idealism', 165.

492 Ibid 168. 
its application. ${ }^{493}$ Such a commitment would only be possible if there were a purely textualist position; if (in)determinacy were not a feature produced by a particular community at a given time but a fixed and static essence of norms.

In international law, this challenge is faced by those who distinguish between non-interpreted norms and their interpretation. Consenting to an international treaty could only commit a State to the content of its rules if they were at least locally determinate independently of their usage. As they are not, a State which, for instance, becomes a founding party to the United Nations Framework Convention on Climate Change can only commit itself to using the concepts employed in the Paris Agreement but cannot commit to their content. This being said, the content of most concepts remains stable over a long period; it is unlikely that carbon dioxide will cease to be called a 'greenhouse gas' in the future. The point is, however, that there is no linguistic essence in the word that would rule out a sudden and radical shift of this usage. The content of concepts is thus the object of continuous negotiation among stakeholders.

Brandom argues that if you commit yourself, you grant others the authority to hold you to it. The content of what you have committed yourself to is secured by others who have the authority to attribute it to you. This is a reciprocal relation: in the first move, you recognise the authority of others to hold you to your commitments while, in the second move, they then actually hold you to it. The content of commitments is determined in the process of negotiation between you and those who have the authority to keep you to your commitments. This constant process of negotiation determines the boundaries of your commitments and how their content is applied correctly. ${ }^{494}$ Negotiation is a historical process, as it 'exhibits a distinctive recognitive structure that is the product of the reciprocal authority exercised on the one hand by past applications of concepts over future ones, and on the other hand by future applications of concepts over past ones.'495 Brandom illustrates his view by referring to a case-law model of communication; past applications of concepts supply the precedents that are used to justify future decisions. Past decisions thus exercise authority over future ones. Even though a judge can ignore and dismiss prior decisions, treating them as an incorrect application of the relevant concepts, this does not mean that she is only formally constrained by precedents. The reason is that the negotiation of the content of concepts is a historical process ranging from the past through the present to the future.

$493 \quad$ Ibid 171.

494 Ibid 172-173.

495 Ibid 179. 
Past decisions exercise authority over the present judge as she knows that her reconstruction of the legal tradition will be subject to the same reconstruction in the future: ' $[t]$ he current judge is held accountable to the tradition she inherits by the judges yet to come.' 496 This model helps to better understand how individuals can be held accountable by others who are not members of the same interpretive communities. Brandom's account clarifies how legal norms can develop normative effects not only within interpretive communities but between them as well.

This account of how we can make commitments and be held to them manages to combine the classical liberal view of self-binding with the pragmatist thesis that the content of concepts is produced through usage. In the classical liberal view, individuals and States can only be constrained if they have endorsed this constraint as binding: '(...) one is in a strict sense bound only by rules or laws one has laid down for oneself, norms one has oneself endorsed. What makes them binding is that one takes them to be binding.' 497 The challenge is that the classical liberal view is at odds with the pragmatist thesis: how can individuals and States bind themselves to a rule if its content cannot be determined in advance but can only be fleshed out in the process of its application? Legal positivists, amongst others, solve the problem by upholding the dualism between non-interpreted norms and their interpretation; we first commit to a norm and then interpret it at a later stage (usually in the process of applying it to a particular situation). I have argued against this view. The advantage of Brandom's model is that we are simultaneously responsible for what we committed ourselves to (the classical liberal view) while the actual content of norms is determined in the process of negotiation with those who hold us to our commitments (a version of the pragmatist thesis). This

496 Ibid 181. A similar thought has been expressed by MICHEL ROSENFELD: ' $[\mathrm{t}$ ] of a writing is neither immediately given nor self-present, but depends on some future reading (or re-collecting) of that writing's past. And since all reading involves a rewriting, all meaning depends on a future rewriting of past writings as rewritten in the present writing which confronts the interpreter. A present writing is a rewritten past writing and a not yet rewritten future writing.' ROSENFELD, 'Deconstruction and Legal Interpretation', 157 (footnote omitted); in a similar vein, ARTHUR JACOBSON writes that '[r] eaders always rewrite texts. Writing too is a reading, a rewriting of texts already written. Writing collaborates in a tradition'. ARTHUR J JACOBSON, 'The Idolatry of Rules: Writing Law According to Moses, with Reference to Other Jurisprudences' (1990) 11 Cardozo Law Review 1079, 1093.

497 BRANDOM, 'Some Pragmatist Themes in Hegel's Idealism', 171; on the crucial importance of State consent in international law, see THIRLWAY, The Sources of International $L a w, 14$; on the surprising resilience of the consensual structure of the international legal order despite numerous attacks, see NICO KRISCH, 'The Decay of Consent: International Law in an Age of Global Public Goods' (2014) 108 The American Journal of International Law 1, 26-28. 
ensures that what you are responsible for is not imposed on you but stems from your own commitment. At the same time, the fact that others hold you to your commitments ensures that there can be a certain distance between what you initially committed to and your current will. You cannot simply change your mind and allege that you no longer feel committed to a certain use of a concept when your obligations start inconveniencing you.

Some international lawyers who read the last paragraphs will be unconvinced that Brandom's understanding of commitments can be of any use in international law; after all, how States can commit themselves and stay committed is one of the enduring challenges of the discipline. ${ }^{498}$ As has been seen in the section on the structural indeterminacy thesis, all theories of legal bindingness that are based on State consent, i.e. the commitment of States to be bound, are beset by the problem that they cannot explain why an international instrument should still oblige a State that no longer considers itself bound. Self-commitment thus only seems to create an 'obligation' as long as it does not hurt. Auto-limitation or self-limitation, i.e. the view that obligations are binding for a State only if it has voluntarily consented to it, has often been criticised as an apologist doctrine. Hersch Lauterpacht denounced it as a legal theory that 'cannot be interpreted otherwise than as a denial of the binding force of international law.' 499 The doctrine has even been depicted as 'the very negation of law and a glorification of force.'500 Equating Brandom's idea of self-commitment with the doctrine of auto-limitation in international law would, however, amount to misunderstanding the former. The main difference is that, according to the doctrine of auto-limitation in international law, a State can only be bound by an obligation if it has agreed to be bound, whereas there is more to Brandom's account of self-commitment. Translated to the realm of international law, a State, according to this pragmatist view, is bound by its commitment not only because it has voluntarily agreed to do so but also because others will hold it accountable. While both in the auto-limitation

498 While (neo-)positivists are able to show how a State can commit itself (by consenting), they are unable to explain how States remain committed once they have withdrawn their consent. Conversely, (neo-)naturalists are unable to link their normative concepts to the commitments of States. This is nothing other than a restatement of KENNEDY and KOSKENNIEMI's structural indeterminacy thesis. For an overview of the argument between proponents and critics of the auto-limitation view in international law, see KoskenNiEmi, From Apology to Utopia, 127-130. For an analysis of how doctrines in international law have tried to evade the problem that State consent can no longer bind a State once it has been withdrawn, see ibid 307-325.

499 HERSCH LAUTERPACHT, The Function of Lawin the International Community (first published 1933, Oxford University Press 2011) 419.

500 Ibid. 
view and in Brandom's approach the first step to create an obligation is taken by the State (the individual), this step cannot simply be reversed under the pragmatist model. Once a State has committed itself, other participants in the international legal discourse will hold it to this commitment. While under the doctrine of auto-limitation, the binding force of international law is indeed lost, as nothing can keep a State from withdrawing its consent to an international legal obligation, this problem is solved in the pragmatist approach.

These two explanations of the basis of legal obligations work on different assumptions. The auto-limitation doctrine assumes that States can consent to norms that have meaning independently of their usage. The pragmatist view denies this. While the doctrine of auto-limitation locates the basis of legal obligation in one single act-the consent of the State, e.g. the ratification of a treaty-, the basis of legal obligation under the pragmatist approach is not only located in the commitment itself but also in the continuous process of negotiation about the commitment's content. In Brandom's model, the contents of concepts are not fixed but continually shaped by their usage, i.e. by the ongoing process of negotiation between involved States and other participants in the international legal discourse. Given that in the pragmatist approach, the content of legal norms is continuously under negotiation and thus depends on the attitudes of different States, a unilateral withdrawal of consent cannot erase the basis of legal obligation. The reciprocal nature of this pragmatist model (your commitment confers authority on others who then hold you to it) ensures that the original commitment sets a process in motion one cannot simply reverse by changing one's mind. Hence its main advantage is that, unlike the doctrine of auto-limitation in international law, it does not lead to a negation of normativity. International law does not collapse into the momentary will of States. Commitments are taken seriously. Therefore, under this pragmatist model, international law is not susceptible to the critique of being an apologist disguise for Realpolitik.

If Brandom's approach is not apologist, Koskenniemi would argue, it must be utopian. Recall that Koskenniemi understands international law as a project built on the liberal doctrine of politics, which rejects principles of natural or divine justice. Because there is no overriding set of values, individuals (and by analogy States) are free and equal. States are free to formulate their own values and equal because there is no hierarchy that would allow preferring the values of one State over those of another. The only acceptable ground for obligations is subjective consent by States. Because all States are equal and there is no standard of evaluation that could override the will of States, only a State itself can determine when it considers itself bound. No other entity can 'know better' what a State wills than the State itself. Combined with the 
requirement that only subjective consent is an acceptable ground of obligation, this conception gives rise to complex constructions such as tacit consent. Such doctrines are an attempt to ground legal obligations in the consent of States even in instances where the State denies its agreement. The difficulty is to avoid the trap of 'knowing better' what a State consents to than the State itself. ${ }^{501}$ Koskenniemi argues that the trap always snaps; doctrines like tacit consent always implicitly take the form of 'knowing better' than the State itself and are thus in violation of one of liberalism's core principles. As naturalist doctrines in disguise, they fall prey to the utopia critique; they are detached from what a State has agreed to. While such doctrines are normative-in the sense of creating a distance between what States have agreed to and their momentary will-, they fail to link their content to what States consented to and thus lose their concreteness. Utopian arguments are the opposite of apologist views, which are concrete but not normative. 502

The fact that in the pragmatist model, States are not always in control of what they commit themselves to would thus be deemed utopian by Koskenniemi. If a State cannot decide for itself at any time exactly what it has consented to, liberal principles are violated. If one's commitments are administered by others who can partly determine what the commitment entails, this amounts to 'knowing better' what a State wants than that State itself:

(...) acceptance cannot be invoked against a State denying it without assuming either 1) that the law-applier 'can know better' what the State has agreed to or 2) that there is some non-acceptance-related criterion whereby we can judge whether acceptance is present or not. Both points involve assuming an objective theory of justice; the former under the guise of 'objective interests', the latter by reference to a naturalistic theory of good faith, reasonableness, or the like. Both are vulnerable to the objection about utopianism. ${ }^{503}$

However, I submit that if we take practice seriously, Brandom's model cannot be criticised as utopian. As argued in Section II.B.2, the structural indeterminacy thesis would only have an impact on the extent of determinacy of international law if it were widely accepted in practice, i.e. by practising international lawyers, judges, legal scholars, and others who refer to international law when making arguments. An isolated theory defending a conception of global

501 KOSKENNIEMI, From Apology to Utopia, 64; KOSKENNIEMI, 'The Politics of International Law', 22.

502 KoskenNiEmi, From Apology to Utopia, 17-23; KOSKENNIEMI, 'The Politics of International Law', 7-9.

503 KosKenNiemi, From Apology to Utopia, 64. 
indeterminacy with a marginal impact on legal practice cannot 'reveal' the true extent of determinacy of international law. What is an acceptable argument depends on standards that are defined within an interpretive community. As admitted by Kennedy and Koskenniemi, most international lawyers do not take the liberal roots of international law that seriously. Exposing the core problems of liberal theory has no impact on the professional practice of most international lawyers. ${ }^{504}$ If we want to take practice seriously, we have to look at which moves are actually performed in the discipline. As it turns out, even the ICJ-one of the highest authorities in international law-'violates' liberal principles without believing in the structural indeterminacy thesis. In what follows, cases decided by the ICJ shall illustrate that 'knowing better' what a State committed itself to than that State itself is a widely accepted argumentative move in international law. If practice is taken seriously, the World Court's judgements cannot be treated as merely an outward show that is in violation of the liberal principles which allegedly constitute the basis of international law. Instead, its decisions have a substantial impact on what can be said in the discipline. While liberal ideas have certainly had a significant influence on international law, they do not form a fixed background scheme against which every international legal argument needs to be evaluated. If the following examples succeed in showing that 'knowing better' is an accepted discursive move in international law, Brandom's model is not susceptible to the utopia-critique.

In the Anglo-Norwegian Fisheries case of 1951, the ICJ was tasked with deciding whether Norway's delimitation of its territorial sea was in conformity with international law. One of the questions was whether the UK had opposed Norway's delimitation practice. ${ }^{505}$ The UK argued that it had not known about the Norwegian system of delimitation, which could therefore not serve as the basis of a historic title enforceable against it. The Court, however, rejected this view and held that the UK must have been aware of Norway's delimitation practice. Therefore, ‘Great Britain's (...) prolonged abstention would in any case warrant Norway's enforcement of her system against the United Kingdom.'506 This argument from the UK's acquiescence amounts to 'knowing better' what the British consented to than they do themselves. ${ }^{507}$ As such, it

\footnotetext{
504 KENNEDY, 'The Last Treatise', 988; KosKenNIEMI, From Apology to Utopia, 600.

505 ICJ, Fisheries (United Kingdom v Norway), Judgement of 18 December 1951, ICJ Reports $116,138$.

$506 \quad$ Ibid 139.

507 KOSKENNIEMI, From Apology to Utopia, 296-297; KOSKENNIEMI indeed considers the ICJ's move of 'knowing better' a form of naturalism and thus unacceptable under liberal premises. In other words, the background scheme of international law (liberal premises) does not allow this move (of knowing better). This dualism between the background scheme and its execution, which KOSKENNIEMI shares with SAUSSURE,
} 
would not be an available argument if the liberal principles which supposedly form international law's basis were taken seriously by the World Court.

Similarly, in 1960, the ICJ rendered its judgement in a case between Honduras and Nicaragua about the validity of an arbitral award by the King of Spain. Nicaragua had challenged the award's validity and thus did not consider itself bound by it. The Court, however, discussed several acts of Nicaragua, including a report of its foreign minister to the Nicaraguan national legislative assembly, the absence of any objection regarding the arbitrator, telegrams, and notes about the award sent by or to Nicaraguan officials. 508 The Court considered these acts to be evidence of Nicaragua's acceptance of the award. ${ }^{509}$ The Court managed to override Nicaragua's current will while still linking the decision back to its sovereign consent. The ICJ thus 'knew better' what Nicaragua had consented to than the Nicaraguan State itself.

Finally, in the Temple of Preah Vihear case of 1962, the ICJ adjudicated on the territorial dispute between Cambodia and Thailand. The question was whether Thailand had known of and accepted a map on which the temple was situated on Cambodian territory. Thailand argued that its silence could not be interpreted as acquiescence. ${ }^{510}$ However, the Court disagreed:

(...) it is clear that the circumstances were such as called for some reaction, within a reasonable period, on the part of the Siamese authorities, if they wished to disagree with the map or had any serious question to raise in regard to it. They did not do so, either then or for many years, and thereby must be held to have acquiesced. ${ }^{511}$

In this case, too, the Court overruled Thailand's own interpretation of its behaviour and inferred said State's consent from its conduct.

These cases illustrate that the ICJ does not shy away from 'knowing better' what a State agreed to than the State itself. According to Koskenniemi, these

does not allow him to take practice seriously enough. Practice can change which moves are accepted in a community and which ones are not. International law does not work like a game of chess that works according to fixed rules; if the king is repeatedly moved two squares and the player gets away with it, this may become an acceptable move. Hence it cannot be ruled out that to 'know better' has become an acceptable move in international law-at least when performed by the ICJ. On why neither law nor language can be conceptualised as a background scheme or set of rules separate from its execution, see Sub-Section II.B.3.i.

508 ICJ, Case Concerning the Arbitral Award Made by the King of Spain (Honduras v Nicaragua), Judgement of 18 November 1960, ICJ Reports 192, 207-211.

509 Ibid 213.

510 ICJ, Case Concerning the Temple of Preah Vihear (Cambodia v Thailand), Judgement of 15June 1962, ICJ Reports 6, 22.

511 Ibid 23. 
'utopian' arguments could only be avoided by making 'apologetic' ones. International law is thus either normative or concrete but never both. This conclusion, however, is not inevitable if we take practice seriously, i.e. if we attach importance to the moves that are actually made in international law. The Anglo-Norwegian Fisheries case, the Arbitral Award case, and the Temple of Preah Vihear case demonstrate that 'knowing better' what a State consented to than the State itself is an argumentative move that occurs in practice. From a pragmatist point of view, this is not just another example of international law's structural indeterminacy but evidence of an argumentative move being accepted within a particular interpretive community in international law. If we think that the extent of legal determinacy depends on which moves are accepted in a specific community, it greatly matters what the World Court repeatedly held. It is more than an outward show. For Koskenniemi, the fact that the ICJ 'knew better' what a State consented to than the State itself does not challenge the underlying liberal premise that sovereign equals always know best themselves what they agreed to. ${ }^{512}$ This liberal premise, according to Koskenniemi, remains entirely untouched even when it is repeatedly violated in practice. While Koskenniemi convincingly analyses classical international law's roots in the liberal doctrine of politics, ${ }^{513}$ he treats the whole subsequent history of international law as a body with one set of stable founding principles. ${ }^{514}$ Once it has been established that international law is based on liberalism, every international legal argument made by every subsequent international lawyer must conform to this background scheme. While the liberal premises may have been shaky at the beginning, i.e. during the emergence of the liberal doctrine of politics from the $16^{\text {th }}$ to the $18^{\text {th }}$ century, 515 today, according to Koskenniemi, they are rock-solid. The reality that the ICJ repeatedly explains to States the content of their own commitments cannot change the fact that international law is based on liberal premises. Repeated violations of the liberal principles, according to Koskenniemi, do not diminish their continued relevance.

Liberal principles are, however, not only violated in certain cases. The examples above where the ICJ 'knew better' what States agreed to than the States themselves are only one kind of instance. Kennedy and Koskenniemi's framework compels to understand every judgement by an international court or tribunal, as well as any other international legal argument, as either in

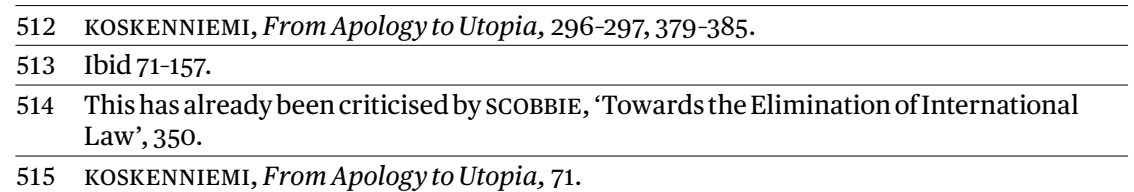


direct violation of a liberal principle (utopia) or the negation of international law (apology). Even though international legal practice has thus not been taking liberal principles entirely seriously for an extended period-if it ever fully did so-, the principles themselves remain untouched. This static relation between practice and its underlying principles should, however, be rethought.

From a pragmatist perspective, the principles an interpretive community considers valid are not set in stone and do not depend on anything other than the community's own practice. Whether international lawyers consider themselves bound by a set of liberal principles does not depend on any theory that is above or behind their practice. It depends on the arguments, regarding practical cases as well as theoretical matters, that are regularly made and accepted within a given community. The fact that the institution with possibly the highest degree of semantic authority516 in the discipline has repeatedly violated the liberal principles underlying international law renders it doubtful at least whether those principles really are the yardstick against which every argument ought to be measured. In a pragmatist view, there are more possibilities than the extremes of liberal principles either being the basis of international law or having nothing to do with the discipline at all. There can be a middle ground where some liberal principles are sometimes relevant. As has been seen in the section on the structural indeterminacy thesis (II.B.2), not all international legal arguments are deconstructed. In the example of the exchange between the Russian Ambassador and the Kazakh Permanent Representative at the UN, it became clear that some arguments are not deconstructed even though it would be possible to do so if liberal principles were always used as the background structure of international law. 517

Since Brandom's model can be defended against both the critique of apology (raised against pure positivism) and that of utopia (levelled against pure naturalism), it enables us to understand in a satisfactory manner how individuals and States can bind themselves and remain bound. It is a model of legal normativity that is rooted in the commitments of States but does not collapse into their momentary will as others have the authority to hold them to their commitments. I have argued how individuals perceive the law through the background conventions of their interpretive communities. Adding Brandom's insight mentioned above that ' $[t]$ he current judge is held accountable to the tradition she inherits by the judges yet to come', 518 enables us to see how legal meanings are stabilised over time. Moreover, the model helps to better

516 On the concept of semantic authority, see Sub-Section II.B.3.iv.

517 See Sub-Section II.B.2.i.

518 BRANDOM, 'Some Pragmatist Themes in Hegel's Idealism', 181. 
comprehend how individuals, who are members of different interpretive communities, can enter reciprocal commitments.

The following example of an ICJJudge shall illustrate how interpretation is constrained not only within interpretive communities but also between them. Assume our judge is a member of mainly two interpretive communities: ICJJudges and human rights advocates (before becoming a judge at the World Court, she was a human rights lawyer). Whenever she applies a legal norm, she makes a commitment others will then hold her to. If, for instance, she is tasked with adjudicating on a case that some argue fulfils the conditions for a humanitarian intervention, she will be held accountable for the way she applies the principle of non-intervention, the prohibition of the use force, its exceptions, etc. The difficulty is that she will be held accountable by present and future members of different interpretive communities in incompatible ways. While her former colleagues who still work as human rights advocates will tend to favour humanitarian intervention, her new colleagues in The Hague may have a different reading of the inherited legal tradition and insist on respecting the sovereign territory of the UN member State concerned. Finally, she concurs with the Court's majority that humanitarian intervention is illegal. Her years on the bench have changed her background conventions; she no longer conceptualises every situation as a human rights problem. Instead, she now considers the long-term advantages of a stable collective security system to be more important than the short-term benefits that would arise from a humanitarian intervention. Her beliefs and assumptions about international relations and the function of international law have partly shifted from those that predominate within the human rights community to those prevalent within the community of ICJ judges. Her former human rights law colleagues will mostly consider her decision a legal mistake. Seen through their background conventions (human rights abuses are intolerable and always have to be stopped, no State can hide behind its sovereignty when committing atrocities, etc.), the decision not to intervene is clearly a wrong interpretation of applicable international legal norms. Her new colleagues in The Hague, as well as other members of their interpretive community, will consider the Court's decision a correct application of international law. Their background conventions (the international system is a response to the World Wars, its function is to guarantee peace and stability above all else, etc.) make them read the UN Charter as clearly prohibiting the use of force except in instances of self-defence and actions taken by the Security Council.

By applying the relevant legal norms of the UN Charter the way she did, our judge committed herself. If a similar case arises in the future, she will be held to her past use of these legal norms by other international lawyers. This 
time, it would be more difficult (though not impossible) for her to argue for humanitarian intervention, as others will hold her to her past commitments. To justify changing her mind would be easier within the interpretive community of human rights lawyers, for they would view her new position as the rectification of a clear legal mistake (unless the ICJ's past decision against humanitarian intervention had changed the background conventions of the human rights community itself). Within the interpretive community of ICJ judges, however, our judge would face a twofold constraint: first, her past use of certain legal norms of the UN Charter is a commitment others hold her to. Second, she knows that her current decision can only be authoritative in the long run if it is going to be upheld by future judges as well. Those future judges will, amongst other factors, decide on the basis of the Court's precedents (including the one in which she concurred with the majority). Therefore, our judge is constrained by past cases through their application by future judges. If, nevertheless, she decides to change her mind and argue for the legality of humanitarian intervention, she risks being marginalised in future processes of negotiation about the content of legal concepts. 519

\section{II.B.3.iii How Questions about the Extent of Legal Determinacy Should Be Framed}

By means of this pragmatist model, it is possible to understand the extent of determinacy of international law exclusively as a function of practice. The finding that legal texts (and other objects in the world) do not contain any meaning apart from their usage does not lead to the conclusion that law is indeterminate. If determinacy were defined as the constraining force inherent to legal texts, the conclusion would indeed be that law is globally indeterminate. But as I have argued, it is impossible to perceive texts in a non-interpreted, acontextual state. Therefore, the conclusion that texts do not contain inherent meaning is merely a theoretical step in the analysis of the origin of legal meanings, i.e. of the constraining force of law. In this section, I have argued that the pragmatist account of how one can commit to a certain concept and then be held to it can explain how meanings in international law are produced and stabilised through practice. This pragmatist account applied to international law is neither susceptible to the critique raised against pure positivism (lack of normativity in cases where consent is not given) nor to the challenges faced

519 Correct interpretations of the law in the past lead to a higher degree of authority in the future. Those who take part in the negotiation of the content of commitments keep score of what they consider correct and incorrect interpretations. A higher score leads to greater authority in the process of determining the content of (legal) concepts. BRANDOM, Making It Explicit, 180-198, 495-613. 
by pure naturalism (insufficient links to the individual or the State). Under this model, the extent of determinacy does not depend on the essence of a legal text but on the practice of interpretive communities. Questions about the extent of determinacy thus cannot simply take the form of ' what is the degree of determinacy of norm X?' or 'what is the degree of determinacy of international law (in general)?' The answer would always be that it is indeterminate if we try to understand the text in a neutral, non-contextual, non-interpreted form. Stand-alone texts, if they could be perceived as such, would be wholly non-constraining, as they do not contain any independent meaning. Therefore, questions taking this form cannot generate insightful answers.

A better, but not entirely adequate, kind of question is 'what is the degree of determinacy of norm $\mathrm{X}$ /international law within a particular interpretive community at a given moment?' Such a query would allow the whole range of possible answers from determinacy to indeterminacy. If two individuals were members of the same interpretive communities, their aligned background conventions would make them read any text in exactly the same way. They would always agree on the extent of legal determinacy. They would be unanimous about identifying some situations as 'easy cases' where the law constrains the outcome. In other cases, they would agree on the locally indeterminate character of law, for instance because two equally valid but conflicting interpretive principles are available. The advantage of such types of questions is that they start from the insight that meanings do not come from isolated texts but are conferred on them by interpretive communities. The disadvantage is that it is unlikely to find two individuals whose memberships overlap exactly. Every individual perceives the world a little differently, as a result of being influenced by at least slightly different interpretive communities. Full agreement between two individuals on every imaginable legal question is thus theoretically conceivable but will hardly ever occur in practice.

Disagreement among jurists is neither the result of a complex text nor of different views within an interpretive community. There are no inherently 'simple' or 'complex' texts, just as there cannot be different views within a single interpretive community (but recall that every individual is a member of multiple interpretive communities). Instead, disagreement is the result of the membership of jurists in different interpretive communities. Research questions about the extent of legal determinacy have to take this into account. Such questions should thus take the following form: 'what is the extent of determinacy of norm $\mathrm{X} /$ international law in the relevant reference group at a given moment?' The relevant reference group always encompasses individuals who are influenced by various interpretive communities. Sometimes they share roughly the same background conventions, in which case there 
will be widespread agreement on the extent of determinacy as well as on the concrete interpretation of the situation in question. At other times, the background conventions among the relevant audience will be so diverse as to hardly allow any agreement. What happens in such situations? How can agreement be reached among individuals who, due to their divergent background conventions, perceive the law differently?

\section{II.B.3.iv How Does a Legal Outcome Come to Be Accepted?}

A correct application of the law is what is accepted as such. ${ }^{20}$ Acceptance is the product of negotiation among members of different interpretive communities about the content of a (legal) concept. Those involved in such negotiations face a threefold constraint: first, they cannot avoid perceiving the law through the lens of their background conventions. Second, they are held accountable by others who have the authority to keep them to their commitments. Third, they are constrained by all the past applications of a legal concept through future applications, which constantly threaten to overrule a novel present interpretation in favour of the past ones. The meaning of Article 3 ECHR (the prohibition of torture and inhuman or degrading treatment) may, for instance, appear evident to an individual interpreting it because she reads the legal text through the lens of her background conventions. Soon she will realise, however, that her own interpretation does not seem as self-evident to others as it does to herself (or the meaning of the norm seems self-evident to others while she perceives it to be ambiguous). She may even be reminded that in the past, she used to understand Article 3 ECHR differently. Those who have the authority to hold her to her commitments make sure that her new interpretation is sufficiently in line with her past understanding of 'inhuman or degrading treatment'. Finally, by consulting the past instances in which Article 3 was applied, she may discover that her own interpretation deviates from an established use of the concept. She knows that her interpretation will only become a reference point if future appliers of the norm do not overrule hers in favour of past applications. This contributes to aligning her own interpretation with the inherited legal tradition. Other stakeholders will go through the same process of adjusting their interpretations. Hence what constitutes a correct application of a legal norm is determined in the process of negotiation within the relevant reference group.

So far, I have only argued that a correct application of the law is what is accepted as such. The open question is how acceptance comes about. Trying

520 On the unsuccessful search for a middle ground between (unsatisfactory) factual acceptance and (inaccessible) objective truth, see Sub-Section II.B.2.iii. 
to answer this question would exceed the scope of the present thesis, but the options will nevertheless briefly be outlined. In the present study, I try to show where legal meanings are produced and, consequently, where researchers should look when asking about the extent of legal determinacy. I have argued that the extent of legal determinacy depends on what is considered to be a legally determined answer within the relevant reference group at a given time. In the introductory chapter, the following definition was given: 'the law is rationally determinate if the class of legal reasons (whatever one's conception of it looks like) is sufficient to justify only one solution to a case.' We are now able to add an element to this definition: what is a justified solution depends on what is considered to be a justified solution within the relevant reference group. In order to answer the question of how wide the frame left open by the law is, one would need to know what is considered to be within that frame. The answer would be a description of the normative attitudes in the relevant reference group, i.e. it describes what is accepted as a correct application of a norm or set of norms. It is not my goal in this thesis to come up with a list of factors leading to such acceptance. In what follows, however, I will provide a brief overview of what can lead members of the relevant reference group to accept the outcome of a legal question. The reason why I include this in the thesis at hand is that if the present analysis is correct, we can only know about the size of the frame left open by law in a given case if we study how acceptance of legal outcomes comes about. Questions of the type 'is humanitarian intervention in accordance with international law?' ought to be answered by analysing whether humanitarian intervention is accepted by the relevant reference group to be within the frame left open by international law. In contrast, doctrinal work in international law cannot provide conclusive answers to the question of what the law in a given case is. It can only contribute to the negotiation of the law's content by providing-more or less authoritative-opinions. What the law is can only be determined by the process of negotiation among relevant actors that results in the acceptance of a legal interpretation or decision. Brandom's model provides a framework for understanding why commitments are binding and thus how normativity can arise from legal practice. It does, however, leave some crucial questions unanswered, such as which factors play a role in making the relevant stakeholders accept that one's present use of a concept is in line with one's past use of it. More generally, it leaves unanswered how the outcome of a legal case or a political decision gets accepted.

There are two possible answers. The first view is that some interpretations are accepted because they are acts of power. This is usually not thought of as undisguised power but more subtly, in terms of power being exercised by making the relevant audience believe that one's interpretation is the right, 
or even universal, one. The second view retains the possibility that actors are genuinely in agreement. ${ }^{521}$ In the present study, these views will only be outlined, and no argument will be made for or against either position.

Carl Schmitt defended the first view in a broader political context when he argued that power includes the ability to shape meanings:

With regard to these decisive political concepts, it depends on who interprets, defines and uses them; who concretely decides what peace is, what disarmament, what intervention, what public order and security are. One of the most important manifestations of humanity's legal and spiritual life is the fact that whoever has true power is able to determine the content of concepts and words. Caesar dominus et supra grammaticam. Caesar is also lord over grammar. 522

The determination of the meaning of words and of what is considered a correct interpretation thus takes the form of a 'semantic struggle', in which agents try to dominate what can be said and how it is understood in their fields. One emerges victorious in a semantic struggle when one's own use of a concept is established as the norm in a linguistic community. ${ }^{523}$ The continuous negotiation of what is an accepted outcome of a political decision is, therefore, not so much characterised by an attempt to induce genuine agreement but rather takes the form of an act of power. Such an understanding of decision-making is not restricted to the political realm. Legal scholars, however, are mostly reluctant to state that the interpretation of law is a function of undisguised power. ${ }^{524}$ Instead, the influence of power is thought of as more indirect; the acceptance of a legal outcome is considered to be the product of a hegemonic

521 VENZKE, How Interpretation Makes International Law, 57-64.

522 CARL SCHMITT, Positionen und Begriffe: im Kampf mit Weimar-Genf-Versailles (Duncker \& Humblot 1988) 202, quoted in CHANTAL MOUFFE, On the Political (Routledge 2005) 87.

523 DIETRICH BUSSE, 'Semantic Strategies as a Means of Politics: Linguistic Approaches to the Analysis of "Semantic Struggles"' in Pertti Ahonen (ed), Tracing the Semiotic Boundaries of Politics (De Gruyter 1993) 121-123; see also JACOB L MEY, 'Zur kritischen Sprachtheorie' in Jacob L Mey (ed), Pragmalinguistics: Theory and Practice (De Gruyter 1979) 423.

524 VENZKE, How Interpretation Makes International Law, 59-60. Even critical legal scholars usually refrain from arguing that legal interpretations are merely acts of undisguised power. ROBERT M COVER came close to such an assertion when he wrote: '[l]egal interpretation takes place in a field of pain and death. This is true in several senses. Legal interpretive acts signal and occasion the imposition of violence upon others: A judge articulates her understanding of a text, and as a result, somebody loses his freedom, his property, his children, even his life.' ROBERT M COVER, 'Violence and the World' (1986) 95 Yale Law Journal 1601, 1601 (footnotes omitted). 
technique of inducing the belief in the rightness of an outcome by dressing it in legal clothes. Defending this view, Koskenniemi writes: '[i]nstead of appearing as a stable set of normative demands opposed to international politics, international law is better understood as an aspect of hegemonic contestation, a technique of articulating political claims in terms of legal rights and duties.' 525 International law thus cannot speak truth to power but is an expression of power. If there is no distinctively legal normative realm, agreement on answers to questions formulated in legal terms cannot be independent of the power dynamics that govern politics and morality: “"[b]eing convinced”, then, is a matter of giving up the fight, or of accepting the unstated moral and/or political values which lie beneath a given line of reasoning. ${ }^{526}$ In such a view, the answer to a legal question is not accepted because of the use of undisguised power but because a contested moral and/or political choice is successfully masked as the result of a neutral legal analysis. Since international law cannot deal with a situation independently of moral and/or political considerations, it falls short of its promise to resolve questions in a neutral, technical manner that enables decision-makers to factor out the power dynamics inherent to morality and politics.

Hence stakeholders may all agree on a certain legal interpretation, but their agreement can hardly be considered genuine, as it is rooted in a morality which only appears inevitable because of the power dynamics that stabilise it. When criticising the liberal doctrine of the harmony of interests in international relations theory, E. H. Carr put forward a view of the hegemonic production of reality and morality:

[The doctrine of the harmony of interests] is the natural assumption of a prosperous and privileged class, whose members have a dominant voice in the community and are therefore naturally prone to identify its interest with their own. (...) In so far, therefore, as the alleged natural harmony of interest has any reality, it is created by the overwhelming power of the privileged group, and is an excellent illustration of the Machiavellian maxim that morality is the product of power. ${ }^{527}$

According to this approach, agreement uninfluenced by power seems impossible. Even if stakeholders agree on a given legal interpretation, their agreement is always the product of an exercise of power that succeeded in making them

525 KOSKENNIEMI, 'International Law and Hegemony', 197.

526 KENNEDY, 'Theses about International Law Discourse', 357.

527 EDWARD H CARR, The Twenty Years' Crisis 1919-1939: An Introduction to the Study of International Relations (2nd edn, MacMillan 1946) 80-81. 
believe in the correctness of that interpretation. ${ }^{28}$ Under such an approach, genuine agreement, i.e. agreement arising independently of any form of power, is a dangerous illusion. In the absence of an objective rationality, agreement on the correct meaning of a political or legal term is thus always the result of a hegemonic struggle. 529

If this is correct, the extent of determinacy of law ultimately depends only on the structure of power relations. The stakeholders in a legal case may think that they genuinely agree, i.e. that they made their decision on the basis of their legal skills and, if there is discretion, their own moral and political convictions as well. However, these beliefs are, in turn, merely the products of existing power dynamics. If the extent of determinacy depends on what the stakeholders accept as a correct legal outcome, and if that acceptance is ultimately merely a function of power, research about normative reasons only superficially contributes to figuring out how wide the frame left open by law is. Such research would only be interesting in the form of an analysis of what stakeholders believe to be morally correct or politically wise, whereas the most relevant research would be about how power shapes moral and political convictions. In other words, knowledge about the limits of legal discretion could only be attained by scrutinising power relations. Such a view assumes that rationality and moral values do not exist independently of the beliefs of a particular reference group. The problem with this approach is that if it exceedingly difficult to prove the presence of an objective rationality and an objective morality, it is as difficult to prove the contrary. 530

The second view on what leads to the acceptance of an answer to a political or legal question entails the possibility of genuine agreement. Not every

528 SONJA BUCKEL and ANDREAS FISCHER-LESCANO argue that hegemony is a worldview on which the majority's preferences, morality, and philosophical principles are based. Agreement is thus merely a function of hegemonic struggles. SONJA BUCKEL and ANDREAS FISCHER-LESCANO, 'Gramsci Reconsidered: Hegemony in Global Law' (2009) 22 Leiden Journal of International Law 437, 437; ROBERT w COX contends that hegemony on the international level is not dependent on coercion but achieves most of its goals through legitimising the norms of the world order. In most cases, agreement is a product of the acceptance of international norms that are legitimised in such a way. ROBERT w COX, 'Gramsci, Hegemony and International Relations: An Essay in Method' (1983) 12 Millennium: Journal of International Studies 162.

529 CHANTAL MOUFFE argues that "[w]hat is at a given moment considered as the "natural" order-jointly with the "common sense" which accompanies it-is the result of sedimented practices; it is never the manifestation of a deeper objectivity exterior to the practices that bring it into being.' MOUFFE, On the Political, 18; given that there is no external standard against which any position could be evaluated, MOUFFE rules out the possibility of agreeing on a political order purely by rational considerations that are independent of power relations. Ibid 106-107.

530 VENZKE, How Interpretation Makes International Law, 62. 
decision is a function of power. Approaches that rely on authority rather than power are able to sustain such a view. ${ }^{531}$ However, even conceptions of authority that distinguish it from forms of power may, under the above-mentioned first approach, be understood as nothing other than the surface of the underlying power structures. The present analysis of the extent of legal determinacy is agnostic about this question. The purpose of the present sub-section is merely to show that if the extent of legal determinacy indeed depends on what stakeholders accept as a legally correct outcome, there are two main avenues for studying legal determinacy further: one focuses purely on power relations while the other does not rule out that genuine agreement may be possible.

The concept of 'semantic authority', for instance, does not categorically rule out the possibility of genuine agreement. Venzke defines it as 'an actor's capacity to influence and shape meanings as well as the ability to establish its communications as authoritative reference points in legal discourse.'532 Actors with semantic authority are able to shape the content of legal norms and can structure the discourse by establishing reference points that cannot be ignored by others. ${ }^{533}$ Various factors contribute to semantic authority. Explicit delegation, i.e. someone having conferred the competence to do something on an actor, is clearly one of the most important ones. Brandom emphasises this point as well: by using a legal concept in a certain way, actors commit themselves and thus grant others the authority to hold them accountable to their past uses of the concept. ${ }^{534}$ But other factors also matter, such as perceived expertise and moral appeal. 535

The advantage of such an approach is that consent, expressed e.g. by ratifying an international treaty, is taken seriously as its normative force is captured through the concept of authority. At the same time, the concept of semantic authority is based on the rejection of the dualism between a norm and its interpretation. Therefore, it takes into consideration that law-making

531 Authority can be defined negatively as being in contradistinction to both coercion by force and persuasion through arguments: '[s]ince authority always demands obedience, it is commonly mistaken for some form of power or violence. Yet authority precludes the use of external means of coercion; where force is used, authority itself has failed. Authority, on the other hand, is incompatible with persuasion, which presupposes equality and works through a process of argumentation. Where arguments are used, authority is left in abeyance.' HANNAH ARENDT, Between Past and Future: Six Exercises in Political Thought (Viking Press 1961) 92-93.

532 VENZKE, How Interpretation Makes International Law, 63; see also VENZKE, 'Semantic Authority, Legal Change and the Dynamics of International Law', 117.

533 VENZKE, How Interpretation Makes International Law, 63.

534 BRANDOM, 'Some Pragmatist Themes in Hegel's Idealism', 172.

535 VENZKE, How Interpretation Makes International Law, 64. 
does not only occur in the process of agreeing on the legal sources. Instead, the ratification of an international treaty is understood to be merely the starting point of a process of negotiation within the relevant reference group. Those with semantic authority more often succeed in making their vision of the law prevail. Genuine agreement may or may not exist under such a conception. Whether authority is ultimately based on power depends on whether the perception of legitimacy that sustains the authority is itself a function of power dynamics. This is a crucial question but one that shall not be addressed further in the present study.

The preceding paragraphs raised new issues that arise if the analysis in the present research can be upheld. I have tried to contribute to figuring out where legal meanings, and thus the extent of legal determinacy, come fromand where it is pointless to look for them. Exactly how they are produced is not addressed in the present study. I hope that the present study has clarified where the contents of legal concepts do not originate: meanings do not slumber in legal texts, waiting to be extracted from them. Hence the idea that the process of law-making culminates in the establishment of a legal source, e.g. in the ratification of an international treaty, ought to be rejected. Neither can individual interpreters confer their idiosyncratic meaning on a text, as their views are necessarily rooted in shared systems of intelligibility. Legal meanings are perceived as a function of the background conventions shared within an interpretive community. Individuals thus read legal texts in ways shaped by their membership in different interpretive communities. The content of legal concepts is then determined in the process of negotiation with other stakeholders who belong to different interpretive communities. The present research has outlined this process of negotiation but left open the question of how exactly acceptance comes about. Most importantly, the issue of the degree to which power dynamics play a role in obtaining acceptance for a legal outcome has only been raised.

The two-step approach to the determination of legal meanings described in this study applies to both international and domestic law-first, legal meanings are perceived through the background conventions of interpretive communities; second, the content of legal norms is negotiated between individuals who are members of different interpretive communities. There are, however, important differences between municipal legal systems and the international legal order with regard to the extent of legal determinacy. 


\section{II.B.3.v The Extent of Determinacy in Domestic and International Law}

Kammerhofer denies that international law is more uncertain than domestic law:

From a theoretical point of view, (...) international law is not categorically more uncertain than any other legal system. International law and municipal laws are not categorically different legal orders, as traditional scholarship sometimes argues. Uncertainties occur in municipal settings just as much as they do in international law. The structural problems of international law are the same as those of any law or of any normative system. Municipal systems and the people involved in their operation just happen to be better at hiding these problems. ${ }^{536}$

I can only partly concur. There is indeed no categorical difference between the two legal systems regarding the way legal meanings, and thus legal (in)determinacy, are produced. When it comes to the extent of legal determinacy, the differences between domestic and international law seem to be ones of degree rather than of kind. Regarding other matters, such as the implementation and enforceability of legal decisions, the differences between the two levels are, of course, fundamental. However, the discussion of implementation and enforceability should not be confused with the one of legal (in)determinacy.

Following the position put forward in this study, the extent of legal determinacy depends on what is accepted by the relevant reference group as an outcome determined by law. This is the case in both domestic and international law. The main reason why domestic systems exhibit a greater extent of legal determinacy is that within them, the relevant reference groups tend to consist of people who are members of a more homogenous set of interpretive communities. Domestic constitutions are written in terms similarly vague and ambiguous as the UNCharter or the ECHR. If their meanings are more certain, i.e. if the degree of legal determinacy is higher, this is mainly because jurists and other relevant stakeholders perceive them in a relatively similar way even before the process of negotiation about their content has started. Moreover, the process of negotiation about the meaning of constitutional norms works more smoothly; it is easier to keep track of who made what commitment, and to keep score of which arguments were (perceived as) correct in the past. Because there is less disagreement about legal meanings in the first place

536 JÖRG KAMMERHOFER, Uncertainty in International Law: A Kelsenian Perspective (Routledge 2011) 2 . 
and as it is better known whose voice matters most when disagreements still occur, domestic legal systems usually exhibit a higher degree of determinacy than international law.

Hence I agree with Kammerhofer about the absence of a categorical difference between the two levels when it comes to legal determinacy. However, I disagree that uncertainties occur on both levels to the same extent but are simply better hidden in domestic legal systems. Kammerhofer's view reflects the widespread assumption that the extent of legal determinacy and the actual functioning of the legal system can be separated. As I have argued, however, legal practice is all there is when it comes to the extent of the determinacy of law. Legal practice thus cannot be separated from structural problems that allegedly exist somewhere above or behind-at any rate independently of-it; structural problems do not affect the extent of legal determinacy as long as they are successfully hidden. A structural problem may only lead to indeterminacy when it is not hidden. As I already outlined in Section II.B.2, the alleged structural problems arising from the paradoxes of liberalism do not render international law indeterminate. The reason is that their existence does not matter if they are hidden. Regarding the extent of legal determinacy, only phenomena that are perceived to be a problem really are a problem. Again, I do not argue that we can never criticise any system for being based on a flawed theory, wrong premises, and the like; far from it. The argument is merely that 'structural problems' do not affect the extent of legal determinacy as long as they are not widely considered to undermine the constraining force of law. 537

The (imaginary) global determinacy thesis, linguistic indeterminacy, and indeterminacy arising from the interpretation of norms or from fact-ascertainment all apply to both the domestic and the international level. Among the different (in)determinacy theses analysed, only the structural indeterminacy thesis is, at least at first sight, restricted to international law. However, Kennedy and Koskenniemi's structural indeterminacy thesis is strongly influenced by indeterminacy claims put forward by critical legal scholars in domestic law. ${ }^{538}$ The difficulty of reconciling social order with individual freedom under the liberal doctrine of politics is at the root of the structural indeterminacy thesis on both the domestic and the international level. As international law is based on liberalism, Koskenniemi argues, it is afflicted with its fundamental problems. ${ }^{539}$ However, the structural indeterminacy thesis is most plausible on the international level. If there is a fundamental problem in the

\begin{tabular}{ll}
\hline 537 & See Section II.B.2. \\
\hline 538 & See Section II.A.4. \\
\hline 539 & See Sub-Section II.A.4.iii.
\end{tabular}


liberal doctrine of politics regarding how individual consent can be the only legitimate basis for any social order, which, nevertheless, sometimes needs to override the will of some individuals, this issue seems to be accentuated in a world of de facto (partly) independent States. In a well-functioning State, nobody is de facto free to assault his neighbour without serious consequences. On the international level, however, there are at least a few powerful States that in fact do have a higher degree of freedom to attack their neighbours than individuals have to assault their flatmates. While theoretically the same difficulties exist on the domestic and international level, the challenge of reconciling individual freedom with social order under liberal premises seems to be more acute in practice on the international level. Because 'social order' is constantly threatened on the international plane, the structural indeterminacy thesis appears more plausible in international law than in domestic law.

If the analysis in the present study can be upheld, the structural indeterminacy thesis, despite its prima facie plausibility, is unable to demonstrate the global indeterminacy of international law. The fact that the structural indeterminacy thesis cannot be upheld does, however, not mean that the extent of legal determinacy is the same in international law as in domestic legal systems. It merely means that the same tools can be applied on both levels to study it. The difference in the extent of determinacy between the two levels is due to the fact that the relevant stakeholders, or reference groups, in international law are more heterogeneous than those within domestic legal systems. As there is no single, unified 'invisible college of international lawyers' 540 but a multiplicity of interpretive communities that structure the minds of stakeholders in international law, it is unsurprising that opinions on what an international legal norm 'evidently' means tend to diverge much more than views on the meaning of domestic norms. Therefore, the process of negotiating the content of legal norms usually is even more arduous than on the domestic level. The result is that stakeholders can agree less often on answers to legal questions. As the extent of legal determinacy depends on what stakeholders agree to be within the frame left open by the law, less such agreement means a lower extent of legal determinacy in international law compared to domestic legal systems.

540 SCHACHTER, 'The Invisible College of International Lawyers'. 



\section{Conclusion}

What are the implications of the position defended in this study for research on the extent of legal determinacy? How can we focus on the practice of particular institutions if the perception of empirical facts is as inter-subjective as the law it purports to clarify? Before answering these questions (III.B), the main arguments that have been put forward will be summarised (III.A). Lastly, the stabilising and destructive force of stories told by international lawyers will be highlighted (III.C).

\section{III.A Summary of Findings}

In this study, the most important (in)determinacy theses in international law put forward since the 1920 s have been described ${ }^{541}$ and critically analysed. ${ }^{542}$ I have argued that nobody, since the 1920s if not earlier, has explicitly defended a conception of global determinacy, i.e. the view that each and every legal question has one correct answer. ${ }^{543}$ Regarding the indeterminacy law inevitably shares with the language through which it is expressed, there is a broad consensus that within a given context, words have a stable core of meaning and a penumbra of uncertainty. ${ }^{544}$ Among legal indeterminacies that arise from reasons specific to law, two main categories have to be distinguished: international law can be indeterminate due to the composition of valid legal norms. For instance, there may be conflicting methods of interpretation or incompatible principles of international law. Moreover, indeterminacies may arise from uncertainties in ascertaining the legally relevant facts. 545 The most radical indeterminacy thesis constitutes the second group, as it does not focus on the properties of valid norms of international law but on legal validity itself. The structural indeterminacy thesis claims that international law is globally indeterminate, i.e. indeterminate in all cases, because no coherent account of the grounds of legal validity can be upheld. 546

\begin{tabular}{ll}
\hline $\mathbf{5 4 1}$ & See Part II.A. \\
\hline $\mathbf{5 4 2}$ & See PartII.B. \\
\hline $\mathbf{5 4 3}$ & See Section II.A.1. \\
\hline $\mathbf{5 4 4}$ & See Section II.A.2. \\
\hline $\mathbf{5 4 5}$ & See Section II.A.3. \\
\hline $\mathbf{5 4 6}$ & See Section II.A.4.
\end{tabular}


In the second main part of the present thesis, I have discussed the production of legal meanings and its implications for (in)determinacy theses of international law. I have argued that objects in the world-including legal texts, rules, and facts-cannot be perceived in a non-interpreted state. Seeing or reading a text cannot be distinguished from interpreting it. If legal texts could be perceived in a non-interpreted state, they would not contain any meaning; there is no linguistic essence of a stable core of meaning.

If meanings do not slumber within some linguistic essence, they could either be found in the intentions of the text's author(s) or conferred on the text by those who interpret it. Even those scholars who hold that the meaning of a text derives from the intentions of its author acknowledge that we have no method for discovering the objectively correct authorial intent. At best, we can make assumptions about what the author(s) of a text may have intended in a given context. Such assumptions necessarily have to be made by those who interpret legal norms. ${ }^{547}$

If meaning emanates neither from the (legal) text itself nor directly from the intent of its author, it has to be conferred on it by those who interpret it. The question then arises whether individual interpreters can confer their own subjective reading on the text or whether they are constrained by commonly accepted ways of interpretation. As individuals can only form their views within a system of intelligibility that precedes them, their own beliefs are always ultimately rooted in background conventions that are shared by members of the same interpretive communities. Just as there are no independent texts, there are no independent individual interpreters, either. Hence the meaning of a text can be grasped neither objectively nor subjectively, only inter-subjectively. Individual opinions are a function of an individual's unique combination of memberships in several interpretive communities. The perception of a legal text by an individual is thus always constrained by the background conventions of the interpretive communities they belong to. Thus the fact that free-standing texts, if they could be separated from how they are interpreted, do not contain any meaning does not signify that legal interpretation is unconstrained. To the contrary, readers are always constrained by their background conventions, often to such an extent that it appears to them as if a text had only one, self-evident meaning.

Many objects of interpretation appear as if they had the same such selfevident meaning for every existing interpretive community. This may give rise to the illusion that such objects of interpretation contain inherent meaning. However, the stability of their meanings is solely the product of widespread 
agreement, not of any inherent qualities of objects of interpretation. Moreover, this fact does not lead to indeterminacy; virtually all English-speakers would agree that a 'car' is correctly termed a 'vehicle'. Both in law and in language, applications of concepts are determinate most of the time (because context is always available). The analysis in the present study is more clearly relevant in cases where objects of interpretation do not appear to contain selfevident meaning and their meaning is contested. In such cases, it greatly matters whether meaning is inherent to objects of interpretation or whether it is conferred on them. ${ }^{548}$

Under the most widely held view, legal norms are first created and then, in a second step, interpreted. However, if norms cannot be perceived in a noninterpreted state (and thus cannot productively be said to exist in such a state), the dualism between a norm and its interpretation collapses. For those who uphold this dualism, the question of legal (in)determinacy is about the constraining force of not-yet-interpreted legal norms. What they ask is to what extent legal norms constrain their own interpretation (which usually takes place in the process of applying a norm to a particular situation). From this point of view, the outcome of the present study would indeed be that law is indeterminate in all cases, as texts do not contain any meaning before they are perceived, i.e. read and thereby interpreted. However, imagining 'law' as 'acontextual legal norms' would render it impossible to adequately answer the question of legal (in)determinacy. Instead of examining the (alleged) inherent properties of texts, the extent of legal determinacy ought to be studied by analysing how interpretive communities confer meanings on them. If we have no access to an objective truth, nothing other than acceptance within a given reference group can serve as the standard of correctness; a legal solution is correct, i.e. legally determined, if it is accepted as such by the relevant stakeholders. When analysing the extent of legal determinacy, the focus should thus be on what is accepted within the relevant reference group (which usually consists of individuals who are members in a variety of interpretive communities).

An 'easy case', in which everyone in the reference group agrees that there is only one legally correct solution, can come to be that 'easy' in two different ways. Firstly, it can be the product of a situation in which the background conventions of all the stakeholders make the same outcome seem self-evident from the start. Secondly, an 'easy case' can be the result of a process of negotiation between individuals who are members in different interpretive communities. Agreement is not a function of the determinacy of the text but results from background conventions shared by the relevant stakeholders as well as

548 See Sub-Section II.B.1.ii. 
a process of negotiation among them. The same applies to 'hard cases', i.e. legal questions where the relevant reference group disagrees about the solution. The matter should then be looked at in two different steps: first, how is the legal question treated within an interpretive community? Secondly, how do individuals, who are members of different interpretive communities, negotiate about the answer to a 'hard' legal question? Indeterminacy can thus be the product of two possible scenarios. First, the law is indeterminate if all the relevant stakeholders agree that there is more than one correct legal answer to a question. Second, and more often, the relevant reference group may disagree. In such situations, the stakeholders have to negotiate the answer to the 'hard' legal question. In cases where they cannot agree on only one answer, the law is indeterminate as well.

\begin{tabular}{|lll|}
\hline stakeholders ... & determinacy & indeterminacy \\
\hline agree ... & $\begin{array}{l}\text { that there is only one } \\
\text { ('self-evidently') correct answer }\end{array}$ & $\begin{array}{l}\text { that there is more than one } \\
\text { correct answer }\end{array}$ \\
\cline { 1 - 2 } disagree ... & $\begin{array}{l}\text { initially but then come to agree } \\
\text { on one correct answer }\end{array}$ & $\begin{array}{l}\text { and do not reach agreement on one } \\
\text { answer, so disagreement persists }\end{array}$ \\
\hline
\end{tabular}

Indeterminacy does not stem from the inherent vagueness or ambiguity of words and sentences, given that texts have no inherent qualities. The same reasoning applies to the indeterminacy arising from the composition of valid legal norms; some scholars studying the extent of legal determinacy hold that if two hierarchically equal, but conflicting norms exist, the law is locally indeterminate on this point. However, this is not necessarily so. The extent of legal determinacy depends on how such conflicts of norms are perceived by the relevant reference group evaluating the case; if human rights obligations might be seen to conflict with the prohibition of intervening in matters of domestic jurisdiction, this does not automatically lead to indeterminacy if, for instance, the inviolability of sovereignty is clearly regarded as the highest value underlying international law within the relevant reference group. Local indeterminacy only arises where the law is perceived to contain two hierarchically equal but conflicting norms. What matters is not the existence of valid legal norms in their non-interpreted state (because in such a state, norms would be devoid of meaning) but, firstly, how they are read by the interpretive communities involved and, secondly, whether these different communities come to an agreement in their process of negotiation. Just like legal texts, 'facts' are not self-evident either, nor do they contain inherent meaning. Instead, meaning is conferred on them. This insight allows conceptualising the challenges surrounding customary international law as relating to fact-ascertainment: which physical and verbal acts of States are considered to be relevant State practice 
and opinio juris and thus contribute to the formation of customary international law? The answer is not found in the facts themselves, but in how the relevant reference group confers meaning on them. ${ }^{549}$

Kennedy and Koskenniemi, in their structural indeterminacy thesis, do not argue that international law is indeterminate because of the open texture of language or for reasons relating to the characteristics of valid legal norms. Instead, they maintain that international law is indeterminate in all cases because no coherent account of legal validity can be established under the liberal principles international law is based on. I have argued that the structural indeterminacy thesis misunderstands the relation between theory and legal practice by regarding them as incommensurate. Theory does not stand apart from or above practice but is one of its forms. This misconception of the relation between theory and practice results in Kennedy and Koskenniemi not taking legal practice seriously enough. Consequently, the fact that legal practitioners do not attach great importance to the liberal assumptions which allegedly form the basis of international law is overlooked. The actual argumentative moves that are accepted in international law cannot be brushed aside as merely an outward show that disguises what supposedly is really going on behind the scenes. A theory about the structural indeterminacy of international law only has an impact on the extent of legal determinacy if its assumptions and their consequences are at least to some degree accepted by international lawyers (including academics, judges, diplomats, and others who professionally deal with international law). Studying-what Kennedy and Koskenniemi would understand as-the 'outward show' of international legal argument is enough to analyse the extent of legal determinacy. Any inquiry into the extent of legal determinacy should focus on the assumptions that are actually held and the argumentative moves that are effectively accepted. Once we transcend the dualism between a theory in the background (such as the liberal doctrine of politics) and an 'outward show' (what courts and international lawyers say and do), we are in a position to comprehend how legal meanings-and thus the extent of legal determinacy-are solely a product of practice. 550

I have argued that meanings are conferred on legal texts by readers who are part of interpretive communities whose background conventions they share. This view dispenses with the dualism between rules and their interpretation because interpretation is not understood as the discovery of the meaning inherent to rules. Instead, the interpretation of a rule is the process

549 See Sub-Section II.B.1.ii.

550 See Section II.B.2. 
whereby legal meanings are created. If it is not legal texts but the background conventions of interpretive communities that give meaning to legal concepts, are those background conventions not just another set of rules? Hence there is a risk of the dualism between rules and their interpretation sneaking back in. A reintroduction of the dualism would leave us with the same unanswerable question we started with: what is the constraining force of rules? Rules cannot be clarified by more rules (such as by Articles 31-33 VCLT). This path would lead to an infinite regress; rules all the way down. I have argued that background conventions of interpretive communities should not be understood as a set of rules, and that therefore the dualism between rules and their execution (i.e. their interpretation) does not sneak in through the backdoor. Instead, the background conventions of interpretive communities should be understood as prior knowledge about a practice which can only be gained through experience. Hence rules cannot be understood by referring to more rules, but ultimately only by having practical experience. In other words, legal meanings are solely rooted in practice. ${ }^{551}$

If rules do not have any inherent meaning, we are left without an account of how States can bind themselves. As long as the dualism between rules and their interpretation was upheld, the answer was straightforward: States consent to a non-interpreted rule, which can later be interpreted. This process of interpretation is then at least partially constrained by the meaning contained within the rule. This account, however, is no longer viable once the dualism between rules and their interpretation is abandoned. Therefore, the need for a reconstruction of normativity in international law arises; I have argued that a pragmatist model is able to explain how States can bind themselves to-and remain bound by-legal obligations without relying on the dualism between norms and their interpretation. According to the pragmatist model, by endorsing a legal concept, States can commit themselves to using it. However, the content of legal concepts is not set in stone. By committing to a given legal concept, a State implicitly confers on others the authority to hold it to it. The content of the concept is then negotiated between the committed State and those who hold it accountable. This negotiation does not only take place between the committed State and those who hold it to its commitment but takes account of past legal decisions (understood in a broad sense). When applying a legal norm, a State representative is constrained by the legal tradition he inherits through future applications of the law. Today's interpretations are constrained by the past through the future; only if the decisions taken in the present, which are based on an understanding of the inherited

551 See Sub-Section II.B.3.i. 
legal tradition, are going to be upheld in the future can today's applications of the concept have a long-term impact.

This pragmatist model escapes the critiques of pure positivism and pure naturalism. Doctrines in international law that locate the basis of legal obligation in the consent of States (such as the doctrine of auto-limitation) cannot explain how a State continues to be bound by its commitments once it has revoked its consent. Under the pragmatist view, States continue to be held to their commitments by others. International law thus remains normative even when a State withdraws its consent. Hence the pragmatist model, unlike purely positivistic accounts, is not vulnerable to the critique of being an apology of power. Moreover, some international lawyers would argue that 'knowing better' what a State has agreed to than that State itself is not an available argument, as it is susceptible to the critique raised against pure naturalism; in other words, it would violate the liberal principle that every State can define its own will and that, therefore, no position can be imposed on a State. If we take international legal practice seriously, however, we are forced to acknowledge that 'knowing better' what a State's obligations are than that State itself is an accepted argumentative move in international law. This is evidenced by the practice of the ICJ (which has, for instance, resorted to the 'knowing better' argument in the form of 'acquiescence'). The fact that under the pragmatist model States can be held to their commitments by others does thus not fall prey to the criticism raised against pure naturalism. ${ }^{552}$

Under the above considerations, research about legal (in)determinacy should be framed as follows: "what is the extent of determinacy of international law in the relevant reference group at a given moment?' Such a framing takes into consideration that meanings are not waiting to be discovered in legal texts but are conferred on them by the relevant stakeholders, i.e. by individuals who contribute to the negotiation of the content of a legal text. An outcome is within the frame left open by law if it is so accepted by the relevant reference group. Therefore, local indeterminacy occurs where the relevant reference group agrees that the law does not lead to only one correct outcome, e.g. in cases where equally valid but conflicting principles are available, or when there is disagreement in the reference group about what the correct outcome is. International law would be globally indeterminate if the structural indeterminacy thesis were widely accepted, i.e. if every international legal argument were deconstructed as lacking a coherent account of legal validity. I have argued that while there are cases of determinacy and local indeterminacy, international law is not globally indeterminate

552 See Sub-Section II.B.3.ii. 
except for a small group of scholars who uphold the structural indeterminacy thesis. 553

If the extent of determinacy depends on factual acceptance, an important question is how such acceptance comes about. In the present study I have only established that legal meanings and thus legal determinacy are products of negotiation among members of the relevant reference group, which encompasses individuals whose thinking is structured by diverse interpretive communities. Exactly how agreement is achieved is beyond the scope of the present thesis. Most importantly, research on the processes of negotiation about the content of legal meanings would need to answer the prior question of whether genuine agreement is possible or whether every belief-including what is considered moral, legitimate, or authoritative-is ultimately a function of underlying power dynamics. 554

Lastly, I have argued that international law is less determinate than domestic legal systems because reference groups in the former are usually more heterogeneous. As the relevant stakeholders on the international level are influenced by a wide variety of interpretive communities, the process of negotiating the content of legal concepts is more arduous. As a result, the relevant reference group in international law is more often unable to agree on answers to legal questions. Since the extent of legal determinacy depends on what is accepted by the relevant reference group to be within the frame left open by law, a lack of agreement leads to a lesser degree of legal determinacy on the international level than on the domestic one. ${ }^{555}$

\section{III.B Can Research on Structural Biases Succeed?}

I have argued that research on the extent of legal determinacy is futile when focused on the abstract and fruitful only when looking at the level of practice. (In)determinacy is a product of practice. To state that a particular concept is indeterminate in the abstract is tautological, as its meaning is only conferred on it in the process of interpretation. Relevant research questions instead address the extent of determinacy of a concept as interpreted in a certain practice at a given time. Kennedy and Koskenniemi, while still upholding their (abstract) structural indeterminacy thesis, 556 have moved on to doing

\footnotetext{
553 See Sub-Section II.B.3.iii.

554 See Sub-Section II.B.3.iv.

555 See Sub-Section II.B.3.v.

556 In 2009, KOSKENNIEMI stated that he is 'as committed as ever' to the structural indeterminacy thesis. KosKenNIEMI, 'The Politics of International Law-20 Years Later', 7.
} 
research on the extent of legal determinacy in practice. Their studies have focused on the power of expertise and on the structural biases in particular institutions. ${ }^{557}$ These are exactly the kind of research questions that can lead to useful insights: what structural biases ${ }^{558}$ guided the decisions taken by military lawyers during the Iraq war? What, concretely, does balancing military necessity against the principle of humanity in the law of armed conflict mean to them?559 Another promising approach is to ask how UN member States interpret principles of the UN Charter that may be seen to conflict (instead of taking such conflicts to be an inherent property of the Charter). 560 Such questions take practice seriously. Instead of trying to resolve these legal tensions in the abstract, they focus on the structural biases dominating in a particular institution. In other words, research of this kind aims at the processes that determine the meaning of legal norms.

However, there is a problem with such research projects. To understand why certain tensions, e.g. the one between non-intervention and human rights, are resolved in one way or the other, access to facts is necessary. What are, for instance, the beliefs and interests of the relevant stakeholders? What are the power dynamics within a given reference group? Just like legal norms, facts only gain meaning once they are invoked in a particular context. If it is impossible to access the objective meaning of legal norms, it is equally impossible to see facts 'as they really are'. Trying to clarify the law by referring to facts thus merely shifts the same problem to another level. Hence d'Aspremont and Mbengue argue that '(...) when confronted with scientific fact-finding, international adjudicators are dealing with knowledge that is as unstable as the law and which brings them to make a choice between different types of

557 KENNEDY, 'Challenging Expert Rule'; KENNEDY, 'Assessing the Proposal for a Global Parliament'; KENNEDY, 'Law and the Political Economy of the World'; KENNEDY, Of War and Law; KENNEDY, A World of Struggle; KosKenNIEMI, 'The Police in the Temple'; KOSKENNIEMI and LEHTO, ‘The Privilege of Universality'; KOSKENNIEMI, 'Human Rights, Politics, and Love'; KOSKENNIEMI and LEINO, 'Fragmentation of International Law?'.

558 The term 'structural bias' is relatively well known and will thus be used here. However, the word 'bias' has misleading implications: if judges are biased, they are considered to deviate from the right standard, e.g. from a neutral position. But when it comes to conferring meaning on legal norms, there is no such right standard. The inter-subjective 'bias' is all there is and cannot be measured against some objective standard. Hence it would be more accurate to say that research on the extent of legal determinacy should focus on the background conventions of interpretive communities and the negotiation among such communities.

559 KENNEDY, Of War and Law, 143-144.

560 SIDNEY D BAILEY, 'Intervention: Article 2.7 Versus Articles 55-56’ (1994) 7 International Relations 1. 
reasoning or rationality. ${ }^{561}$ Despite advocating research on structural biases, Koskenniemi-somewhat self-contradictorily-actually is one of the most outspoken critics of empirical research in international law:562

(...) these new realists, in their hubris, believe in the power of their predictive and explanatory matrices and think that words such as 'power,' 'bargain,' 'costs and benefits,' or 'legitimacy' mark out entities in the empirical world that would automatically guide policy. But since expert systems are no less indeterminate than law, this move only institutionalizes an anti-political, technical mindset. ${ }^{563}$

If this is correct, research on structural biases cannot shed light on the phenomena it purports to illuminate. An objective understanding of facts is no more achievable than one of law. The only options seem to be to foreground either the meaning of legal norms or the analysis of facts, knowing full well that both are inadequate. ${ }^{564}$ The inter-subjective meanings of legal norms are accessible only if we have a notion of the structural biases that create them, which in turn are based on facts we can only perceive in an inter-subjective way.

However, this dilemma does not undermine the importance of research on structural biases, which cannot avoid referring to facts such as 'agreement', 'power', 'persuasion', etc. Due to the inevitable inter-subjectivity inherent to fact-finding, empirical data should be taken with a pinch of salt. Trying to conclusively settle a legal question by looking at 'the facts as they are found in the world' is naive at best. Nonetheless, research that aims to clarify the law by referring to facts focuses on the right object. Instead of trying to answer legal questions in the abstract, it analyses their context and thus takes practice seriously. Even though statements about facts are just as inter-subjective as statements about the law, at least two reasons make research focusing on facts worthwhile. First, there is no serious alternative. I have argued that legal meanings are purely a product of practice. To look at an abstract level that is severed from practice would thus be meaningless (in the sense of not containing any meaning). However, if we want to look at practice, we cannot but look at its 'facts': what do members of a particular reference group believe? Which arguments are considered persuasive? Who has the authority to overrule what is considered a valid argument? Only if we ask such questions do we have a

561 D’ASPREMONT and MBENGUE, ‘Strategies of Engagement with Scientific Fact-Finding in International Adjudication', 240.

562 GREGORY SHAFFER and TOM GINSBURG, 'The Empirical Turn in International Legal Scholarship' (2012) 106 The American Journal of International Law 1, 9.

563 KOSKENNIEMI, 'Constitutionalism as Mindset', 30.

564 I thank MARTTI KOSKENNIEMI for inputs on this point. 
chance to grasp the meanings of legal concepts and their limits, i.e. the extent of their determinacy. Second, even if we disagree about facts and there is no objectively correct way to resolve such disputes, the negotiation of what constitutes a relevant fact clarifies the roots of our disagreement. If we cannot agree on what 'beliefs', 'objectives', or 'power dynamics' are at play, we have no chance of understanding the reasons why we disagree on what constitutes an (in)correct application of the law. Controversies about empirical facts are analytically prior to disagreements about how to interpret the law. As legal meanings are the outcome of a negotiation process between actors who are members of different interpretive communities, we first need to understand what happens in this negotiation. Empirical research on such facts is thus valuable because the object it focuses on helps to reveal the sources of disagreement. Only if we know more precisely where we disagree is there any chance to come to an agreement. Focusing on facts is more productive than, for instance, a doctrinal analysis of a human rights treaty. If one actor claims that the correct application of the treaty is $\mathrm{X}$ whereas his or her colleague claims it is $\mathrm{Y}$, their disagreement will focus on how to understand the law properly. Assuming that the root cause of their disagreement is that they prioritise security versus privacy concerns differently, their differences can only be understood by looking at the facts, i.e. at their political beliefs.

Research on the extent of legal determinacy should thus try to reveal the structural biases of particular institutions. Even though fact-ascertainment is as inter-subjective as the interpretation of legal norms, empirical research can shed light on the sources of disagreement among stakeholders. This, in turn, reveals what is at the root of legal (in)determinacy: the different ways we perceive the world and how some stakeholders manage to make their view prevail.

\section{III.C Turtles and the Stories of International Lawyers}

Both in astronomy and in international law, an uneasy feeling may come up: how can our planet remain stable if it floats around in empty space? How can international law have any stable meaning if nothing stabilises it? There must be giant turtles stabilising both planet Earth and international law. We may not see them directly, but we know they are there. The fact that we are not in free fall is proof of their existence. Otherwise, why would international treaties provide a stable basis from which we can derive legal obligations? What stabilises their validity? International lawyers know that the immediate answerArticle 38(1) ICJ Statute establishes treaties as a source of international law- 
can only briefly distract from the reality that the ICJ Statute is itself a treaty and thus susceptible to the same uneasy questions. ${ }^{565}$ Where does the ICJ Statute derive its validity from? Presumably from some other treaty, which in turn is based on yet another one; treaties all the way down.

Imagine a public lecture on international law in which the professor explains how international treaties derive their validity from Article 38(1) ICJ Statute. At the end of it, an old lady stands up at the back of the room and says: 'what you have told us is rubbish. The validity of the ICJ Statute itself is based on another treaty.' With a superior smile, the professor responds, 'and where does that treaty derive its validity from?'-'You're very clever, young man, very clever', retorts the old lady. 'But it's treaties all the way down!'566

Recall the lecture on astronomy as described in the introduction to the present study. When the old lady after the public presentation ridiculed the astronomer's conviction that the Earth orbits around the sun and claimed that our planet is instead stabilised by 'turtles all the way down', the scientist had good reasons to look at her with a superior smile; whatever the audience in the lecture hall believed, planet Earth does not rest on the backs of an infinite number of giant turtles. No matter how many people believe in the existence of such turtles, our planet's stability would remain unaffected. But this was a lecture on astronomy, not on international law. The superior smile on the law professor's face when responding to the old lady must have been a forced one; stories cannot directly (de)stabilise the physical world, but they are the creators of the legal universe.

The law professor's superior smile would have been fake, because he knows that he can only look down at the old lady's view as long as she is one of only a few people who believe in it. In law, widely shared stories are the sources of (in)stability. A successful story does not need to explain everything or be free from internal contradictions. Those who believe in it may even be aware of its self-contradictory nature. What matters is whether a story is widely shared and acted upon. If we make doctrinal and theoretical arguments that locate the source of validity in Article 38(1) ICJ Statute, our awareness at the back of our minds that the ICJ Statute cannot derive its own validity from itself does not destabilise international law. Hans Kelsen's basic norm factors out one of the main problems of legal theory-how to find a coherent account of legal validity-and thereby avoids the conclusion that validity can only be explained unhelpfully by an infinite regress. One does, however, not have to

565 See DIGGELMANN, 'Anmerkungen zu den Unschärfen des völkerrechtlichen Rechtsbegriffs', 382-383.

566 A variation on HAWKING, A Brief History of Time, 1. 
adhere to Kelsen's theory of the basic norm to believe that international law can be valid. Taking an introductory class in public international law is enough to learn this; treaties are a source of international law because Article 38(1) ICJ Statute says so. End of the story. Only later will students learn that legal theory cannot convincingly explain why one treaty can declare that other treaties are valid. But by then, advanced students have also learned that this theoretical challenge can be safely ignored. It is at this stage that they start applying Kelsen's theory of the basic norm, even if they have never heard of his ideas: fully aware that there is a theoretical problem with the prevalent conception of legal validity, advanced students understand that it is best to simply store this information and move on.

The professor giving the public lecture on international law had moved on long ago. As an advanced student, he had grown aware of the theoretical problems surrounding the prevalent conception of legal validity, but like most of his colleagues, he chose to take the Kelsenian approach; factor out the theoretical problem and move on. The old lady, however, was more persistent. She could not accept that Article 38(1) ICJ Statute served as the ultimate basis of legal validity. The main difference between her and the professor was not that she had a better grasp of the theoretical problem surrounding legal validity, but simply that she was unwilling to accept this legal fiction. Yet, in believing that there are 'treaties all the way down', she assumed the correctness of another story.

Those who defend the structural indeterminacy thesis, however, reject both of these stories. They believe neither in Kelsen's basic norm nor in an infinite pile of treaties. Instead, they argue that no coherent account of the validity of international law can be established. From this, they conclude that international law must be globally indeterminate-that we must be in free fall. The claim of the structural indeterminacy thesis is that there can be no convincing story in international law, whether it is about a hypothetical basic norm or an infinite regress of sources. This, however, is just another story. Its creative and destructive potential does not depend on its objective correctness but merely on its success with international lawyers. If a majority of international legal scholars and practitioners came to believe in the 'free fall' story told by the proponents of the structural indeterminacy thesis, international law would indeed lose its stability. But most do not believe in it, or if they do, it does not influence their arguments. Instead, international lawyers act as if there were a basic norm; they simply presume that legal validity can be derived from the sources enumerated in Article 38(1) ICJ Statute. Whether they do so because of Kelsen's theory or as a result of their general education in international law is irrelevant. What matters is that the bulk of international lawyers 
make doctrinal and theoretical arguments based on the assumption that international law can be valid. This practice of not deconstructing every legal obligation as ultimately resting on shaky foundations is the reason why international law does not suffer from structural indeterminacy.

Just like planet Earth, international law is not stabilised by an infinite number of turtles or treaties, respectively. Instead, Article 38(1) ICJ Statute is presumed to be the basis of legal validity in international law-and this presumption is stabilising enough. However, this may not be the case forever. If one day the majority of international lawyers start making arguments based on the belief that the validity of international law is ultimately rooted in an infinite pile of treaties, then the old lady will have been right; it's treaties all the way down! At this point, it will be her who gives the public lecture on international law, while the professor who used to teach the class will sit in the audience. When at the end of the lecture, the former professor will sceptically ask the old lady how an infinite regress of treaties could possibly explain the validity of international law, this time it will be her who looks at him with a superior smile. Not because her story is objectively more correct, but as a result of her view now being shared by the majority. It will only be at this point that a student will raise her voice and say:

Your stories about stability and instability, determinacy and indeterminacy-they all sound equally doubtful to me. If you want your view to become the correct one, convince us! What we want to hear is a captivating tale of either an endless pile of treaties, a stabilising platform, or critics questioning it all. So, tell us, which one of these shall play the main role in our story? 




\section{Table of Cases}

European Commission of Human Rights (EComHR)

- Ireland v the United Kingdom, Judgement of 18January 1978, Series A 25, Separate Opinion by Judge Sir Gerald Fitzmaurice

\section{European Court of Human Rights (ECtHR)}

- Golderv United Kingdom, Judgement of 21 February 1975, Series A 18

- Luedicke, Belkacem and Koçv Germany, Judgement of 10 March 1980, Series A 29

\section{International Court of Justice (ICJ)}

- Case Concerning the Arbitral Award Made by the King of Spain (Honduras v Nicaragua), Judgement of 18 November 1960, ICJ Reports 192

- Case Concerning the Temple of Preah Vihear (Cambodia v Thailand), Judgement of 15June 1962, ICJ Reports 6

- Competence of the General Assembly for the Admission of a State to the United Nations, Advisory Opinion of 3 March 1950, ICJ Reports 4

- Constitution of the Maritime Safety Committee of the Inter-Governmental Maritime Consultative Organization, Advisory Opinion of 8June 1960, ICJ Reports 150

- Delimitation of the Maritime Boundary in the Gulf of Maine Area (Canada v United States of America), Judgement of 12 October 1984, ICJ Reports 246

- Fisheries (United Kingdom v Norway), Judgement of 18 December 1951, ICJ Reports 116

- FisheriesJurisdiction (Federal Republic of Germany v Iceland), Judgement of 25July 1974, ICJ Reports 175

- Kasikili/Sedudu Island (Botswana v Namibia), Judgement of 13 December 1999, ICJ Reports 1045

- Legality of the Threat or Use of Nuclear Weapons, Advisory Opinion of 8July 1996, Dissenting Opinion by Judge Weeramantry, ICJ Reports 101

- Legality of the Use of Force (Serbia and Montenegro v Belgium), Judgement of 15December 2004, ICJ Reports 279

- North Sea Continental Shelf (Federal Republic of Germany v Denmark; Federal Republic of Germany v Netherlands), Judgement of 20 February 1969, Dissenting Opinion of Judge Lachs, ICJ Reports 219

- Nuclear Tests (Australia v France), Judgement of 20 December 1974, ICJ Reports 253

- Oil Platforms (Islamic Republic of Iran v United States of America), Judgement of 12 December 1996, ICJ Reports 803 
- South West Africa (Ethiopia v South Africa; Liberia v South Africa), Judgement of 18July 1966, ICJ Reports 6

- South West Africa (Ethiopia v South Africa; Liberia v South Africa), Preliminary Objections, Judgement of 21 December 1962, Joint Dissenting Opinion by Sir Percy Spender and Sir Gerald Fitzmaurice, ICJ Reports 465

- Territorial Dispute (Libya v Chad), Judgement of 3 February 1994, ICJ Reports 6

\section{Permanent Court of Arbitration (PCA)}

- Arbitration between Barbados and the Republic of Trinidad and Tobago, Relating to the Delimitation of the Exclusive Economic Zone and the Continental Shelf between Them, Decision of 11 April 2006, XXVIII Reports of International Arbitral Awards, 147

\section{Permanent Court of International Justice (PCIJ)}

- Case of the Free Zones of Upper Savoy and the District of Gex (France v Switzerland), Judgement of 7June 1932, Series A/B 46, No 17, 97

- Competence of the International Labour Organization in Regard to International Regulation of the Conditions of Labour of Persons Employed in Agriculture, Advisory Opinion of 12 August 1922, Series B, No 2, 8

- Competence of the International Labour Organization to Regulate, Incidentally, the Personal Work of the Employer, Advisory Opinion of 23July 1926, Series B, No13, 6

\section{World Trade Organisation}

WTO Appellate Body

- China-Measures Affecting Trading Rights and Distribution Services for Certain Publications and Audiovisual Entertainment Products, 21 December 2009, Appellate Body Report, WT/DS363/AB/R

- EC-Measures Concerning Meat and MeatProducts (Hormones), 16January 1998, Appellate Body Report, WT/DS26/AB/R

- EC and Certain Member States-Measures Affecting Trade in Large Civil Aircraft, 18 May 2011, Appellate Body Report, WT/DS316/AB/R

- Japan-Taxes on Alcoholic Beverages, 1 November 1996, Appellate Body Report, WT/DS8/AB/R

- United States-ImportProhibition of Certain Shrimp and Shrimp Products, 12 October 1998, Appellate Body Report, WT/DS58/AB/R

- US-Measures Affecting the Cross-Border Supply of Gambling and Betting Services, 7 April 2005, Appellate Body Report, WT/DS285/AB/R 


\section{WTO Panel}

- Canada-Measures Affecting the Export of Civilian Aircraft, 14 April 1999, Panel Report, WT/DS70/AB/R

- United States-Measures Affecting the Cross-Border Supply of Gambling and Betting Services, 10 November 2010, Panel Report, WT/DS285/R 



\section{Bibliography}

ABEL RICHARD L, 'Book Review: Ideology and Community in the First Wave of Critical Legal Studies' (2003) 30 Journal of Law and Society 601-608

ALLOTT PHILIP, ‘The Concept of International Law' (1999) 10 European Journal of International Law 31-50

ALTWICKER TILMANN and DIGGELMANN OLIVER, 'What Should Remain of the Critical Approaches to International Law? International Legal Theory as Critique' (2014) 24 Schweizerische Zeitschrift fürinternationales und europäisches Recht 69-92

ARENDT HANNAH, Between Past and Future: Six Exercises in Political Thought (Viking Press 1961)

AUSTIN JOHN

- Philosophical Papers (Oxford University Press 1961)

- How to Do Things with Words (Oxford University Press 1962)

BAILEY SIDNEY D, 'Intervention: Article 2.7 Versus Articles 55-56' (1994) 7 International Relations $1-10$

BALKIN JACK M, 'Taking Ideology Seriously: Ronald Dworkin and the CLS Critique’ (1987) 55 UMKC Law Review 392-433

BARAK AHARON, 'Hermeneutics and Constitutional Interpretation' (1992) 14 Cardozo Law Review 767-774

BECKETT JASON A, 'Behind Relative Normativity: Rules and Process as Prerequisites of Law' (2001) 12 European Journal of International Law 627-650

BERNSTORFF JOCHEN VON, The Public International Law Theory of Hans Kelsen: Believing in Universal Law (Cambridge University Press 2010)

BIANCHI ANDREA

- 'The International Regulation of the Use of Force: The Politics of Interpretive Method' (2009) 22 Leiden Journal of International Law 651-676

- 'Textual Interpretation and (International) Law Reading: the Myth of (In)determinacy and the Genealogy of Meaning' in Pieter H F Bekker, Rudolf Dolzer, and Michael Waibel (eds), Making Transnational Law Work in the Global Economy: Essays in Honour of Detlev Vagts (Cambridge University Press 2010) 34-55

- International Law Theories (Oxford University Press 2017) 
BIX BRIAN, Law, Language, and Legal Determinacy (Oxford University Press 1993)

BLECKMANN ALBERT, Grundprobleme und Methoden des Völkerrechts (Alber 1982)

BOURDIEU PIERRE

- 'The Force of Law: Toward a Sociology of the Juridical Field' (1987) 38 Hastings Law Journal 814-853

- and WACQUANT LOÏC J D, An Invitation to Reflexive Sociology (University of Chicago Press 1992)

BRANDOM ROBERT B

- Making It Explicit: Reasoning, Representing, and Discursive Commitment (Harvard University Press 1994)

- 'Some Pragmatist Themes in Hegel's Idealism: Negotiation and Administration in Hegel's Account of the Structure and Content of Conceptual Norms' (1999) 7 European Journal of Philosophy 164-189

- 'The Pragmatist Enlightenment (and its Problematic Semantics)' (2004) 12 European Journal of Philosophy 1-16

BRIGGS HERBERT W, 'The Travaux Préparatoires of the Vienna Convention on the Law of Treaties' (1971) 65 The American Journal of International Law 705-712

BRILMAYER LEA, 'Book Review: From Apology to Utopia: The Structure of International Legal Argument' (1991) 85 The American Political Science Review 687-688

BUCKEL SONJA / FISCHER-LESCANO ANDREAS, 'Gramsci Reconsidered: Hegemony in Global Law' (2009) 22 Leiden Journal of International Law 437-454

BURGIS MICHELLE, 'Discourses of Division: Law, Politics and the ICJ Advisory Opinion on the Legal Consequences of the Construction of a Wall in the Occupied Palestinian Territory' (2008) 7 Chinese Journal of International Law 33-63

BUSSE DIETRICH, 'Semantic Strategies as a Means of Politics: Linguistic Approaches to the Analysis of "Semantic Struggles"' in Pertti Ahonen (ed), Tracing the Semiotic Boundaries of Politics (De Gruyter 1993) 121-128

CAMERON ROSS, 'Infinite Regress Arguments' (2018) The Stanford Encyclopedia of Philosophy 
CARDOZO BENJAMIN N, The Nature of the Judicial Process (Yale University Press 1921)

CARLSON DAVID G, 'Liberal Philosophy's Troubled Relation to the Rule of Law' (1993) 43 The University of Toronto Law Journal 257-288

CARR EDWARD H, The Twenty Years' Crisis 1919-1939: An Introduction to the Study of International Relations (2nd edn, MacMillan 1946)

CARRINGTON PAUL D, 'Hail! Langdell!' (1995) 20 Law \& Social Inquiry 691-760 CHOMSKY NOAM, Aspects of the Theory of Syntax (MIT Press 1965)

COLEMAN JULES L / LEITER BRIAN, 'Determinacy, Objectivity, and Authority' (1993) 142 University of Pennsylvania Law Review 549-637

COTTIER THOMAS, Equitable Principles of Maritime Boundary Delimitation: The Quest for Distributive Justice in International Law (Cambridge University Press 2015)

COTTIER THOMAS / KRAJEWSKI MARKUS, 'What Role for Non-Discrimination and Prudential Standards in International Financial Law?' (2010) 13Journal of International Economic Law 817-835

COVER ROBERT M, 'Violence and the World' (1986) 95 Yale Law Journal 1601-1629

COX ROBERT W, 'Gramsci, Hegemony and International Relations: An Essay in Method' (1983) 12 Millennium: Journal of International Studies 162-175

CRAIK NEIL, The International Law of Environmental Impact Assessment: Process, Substance and Integration (Cambridge University Press 2008)

CRAWFORD JAMES, Brownlie's Principles of Public International Law ( $8^{\text {th }}$ edn, Oxford University Press 2012)

CREMER HANS-JOACHIM, 'Völkerrecht - Alles nur Rhetorik?' (2007) 67 Zeitschrift für ausländisches öffentliches Recht und Völkerrecht 267-296

Cruft Rowan / Liao S Matthew / Renzo Massimo (eds), Philosophical Foundations of Human Rights (Oxford University Press 2015)

D'ASPREMONT JEAN

- 'Uniting Pragmatism and Theory in International Legal Scholarship: Koskenniemi's From Apology to Utopia Revisited' (2006) 19 Revue québécoise de droit international 353-359

- Formalism and the Sources of International Law: A Theory of the Ascertainment of Legal Rules (Oxford University Press 2011) 
- 'Martti Koskenniemi, the Mainstream, and Self-Reflectivity', 29 Leiden Journal of International Law (2016) 625-639

- and MBENGUE, MAKANE M, 'Strategies of Engagement with Scientific Fact-Finding in International Adjudication' (2014) 5 Journal of International Dispute Settlement 240-272

DE BRABANDERE ERIC, 'Good Faith, Abuse of Process, and the Initiation of Investment Treaty Claims’ (2012) 3 Journal of International Dispute Settlement 609-636

DE BRABANDERE ERIC / GAZZINI TARCISIO, International Investment Law: The Sources of Rights and Obligations (Martinus Nijhoff 2012)

DE BRABANDERE ERIC / VAN DAMME ISABELLE, 'Good Faith in Treaty Interpretation' in Andrew D Mitchell, Muthucumaraswamy Sornarajah and Tania Voon (eds), Good Faith and International Economic Law (Oxford University Press 2015) 37-59

DERRIDA JACQUES, 'Force of Law: The "Mystical Foundation of Authority"' in Drucilla Cornell, Michel Rosenfeld, and David G Carlson (eds), Deconstruction and the Possibility of Justice (Routledge 1992) 3-67

\section{DIGGELMANN OLIVER}

- 'The Periodization of the History of International Law' in Bardo Fassbender and Anne Peters (eds), The Oxford Handbook of the History of International Law (Oxford University Press 2012) 997-1011

- 'Anmerkungen zu den Unschärfen des völkerrechtlichen Rechtsbegriffs' (2016) 26 Schweizerische Zeitschrift für internationales und europäisches Recht 381-390

DÖRR OLIVER, 'Article31: General Rule of Interpretation' in Oliver Dörr and Kirsten Schmalenbach (eds), Vienna Convention on the Law of Treaties: A Commentary (2nd edn, Springer 2018) 559-616

DUXBURY NEIL, 'The Basic Norm: An Unsolved Murder Mystery’, LSE Law, Society and Economy Working Papers 17/2007, 1-10

DWORKIN RONALD

- A Matter of Principle (Harvard University Press 1995)

- Taking Rights Seriously (first published 1977, Bloomsbury 2013)

EHLERMANN CLAUS-DIETER, 'Six Years on the Bench of the "World Trade Court": Some Personal Experiences as Member of the Appellate Body of the World Trade Organization' (2002) 36 Journal of World Trade 605-639 
ENDiCotT TIMOTHY A o, Vagueness in Law (Oxford University Press 2000)

FALK RICHARD, 'Book Review: International Legal Structures' (1988) 28 Virginia Journal of International Law 1065-1076

FASSBENDER BARDO

- 'Rezension - Jochen von Bernstorff: Der Glaube an das Universale Recht. Zur Völkerrechtstheorie Hans Kelsens und seiner Schüler' (2003) 78 Die Friedens-Warte 297-302

- 'Friede durch Recht: Hans Kelsen und die Vereinten Nationen' in Hauke Brunkhorst and Rüdiger Voigt (eds), Rechts-Staat: Staat, internationale Gemeinschaft und Völkerrecht bei Hans Kelsen (Nomos 2008) 127-147

- 'Hans Kelsen (1881-1973)' in Bardo Fassbender and Anne Peters (eds), The Oxford Handbook of the History of International Law (Oxford University Press 2012) 1167-1172

FASTENRATH ULRICH, 'Besprechung: From Apology to Utopia: The Structure of International Legal Argument' (1990) 31 Archiv des Völkerrechts 182-185

FIKFAK VERONICA / BURNETT BENEDICT, 'Domestic Courts' Reading of International Norms: A Semiotic Analysis' (2009) 22 International Journal for the Semiotics of Law 437-450

FISCHER WILLIAMS JOHN, Some Aspects of the Covenant of the League of Nations (Oxford University Press 1934)

FISH STANLEY, 'Interpreting the "Variorum"' (1976) 2 Critical Inquiry 465-485

- Is There a Text in This Class? The Authority of Interpretive Communities (Harvard University Press 1980)

- Doing What Comes Naturally: Change, Rhetoric, and the Practice of Theory in Literary and Legal Studies (Duke University Press 1989)

- 'There Is No Textualist Position' (2005) 42 San Diego Law Review1-22

- 'Intention Is All There Is: A Critical Analysis of Aharon Barak's Purposive Interpretation in Law' (2008) 29 Cardozo Law Review 1109-1146

FISS OWEN, 'Objectivity and Interpretation' (1982) 34 Stanford Law Review 739-763

FITZMAURICE GERALD

- 'The United Nations and the Rule of Law' (1953) 38 Transactions of the Grotius Society 135-150

- 'The Foundations of the Authority of International Law and the Problem of Enforcement' (1956) 19 Modern Law Review 1-13 
- 'The Law and Procedure of the International Court of Justice. Treaty Interpretation and Other Treaty Points' (1957) 33 British Yearbook of International Law 203-293

- 'Judicial Innovation-Its Uses and Its Perils-As Exemplified in Some of the Work of the ICJ During Lord McNair's Period of Office', Cambridge Essays in International Law: Essays in Honour of Lord McNair (Stevens \& Sons 1965) 24-47

- 'Legal Advisers and Foreign Affairs' (1965) 59 The American Journal of International Law 72-86

FOURET JULIEN / DAILLIER PATRICK / PELLET ALAIN, Droit international public ( $7^{\text {th }}$ edn, LGDJ 2002)

FRANCK THOMAS M / CHERKIS LAURENCE D, 'The Problem of Fact-Finding in International Disputes' (1967) 18 Western Reserve Law Review 1483-1524

FRANK JEROME N

- 'Words and Music: Some Remarks on Statutory Interpretation' (1947) 47 Columbia Law Review1259-1278

- 'Both Ends Against the Middle' (1951) 100 University of Pennsylvania Law Review 20-47

- “"Short of Sickness and Death": A Study of Moral Responsibility in Legal Criticism' (1951) 26 New York University Law Review 545-633

- 'Judicial Fact-Finding and Psychology' (1953) 14 Ohio State Law Journal 183-189

- Law and the Modern Mind (first published 1930, Transaction 2009)

FRY PAUL H, Theory of Literature (Yale University Press 2012)

GARDINER RICHARD, Treaty Interpretation (Oxford University Press 2008)

GARDNER JOHN, 'Legal Positivism: 51/2 Myths' (2001) 46 The American Journal ofJurisprudence 199-227

GARRETT MERILl F, 'Does Ambiguity Complicate the Perception of Sentences?' in Giovanni B Flores d'Arcais and Willem J M Levelt (eds), Advances in Psycholinguistics (North-Holland 1970) 48-60

GONZÁLES NÚÑEZ DENISE, 'Peasants' Right to Land: Addressing the Existing Implementation and Normative Gaps in International Human Rights Law' (2014) 14 Human Rights Law Review 589-609

GRAYLING ANTHONY C, Wittgenstein: A VeryShort Introduction (Oxford University Press 2001) 
GREEN LESLIE, ‘Legal Positivism’ (2018) The Stanford Encyclopedia of Philosophy HAAS PETER, 'Introduction: Epistemic Communities and International Policy Coordination' (1992) 46 International Organization 1-35

HAQUE ADIL A, 'Indeterminacy in the Law of Armed Conflict' (2019) International Law Studies 118-160

HANSEN SUSANNE T, 'Taking Ambiguity Seriously: Explaining the Indeterminacy of the European Union Conventional Arms Export Control Regime' (2016) 22 European Journal of International Relations 192-216

HART HERBERT L A

- 'Positivism and the Separation of Law and Morals' (1958) 71 Harvard Law Review 593-629

- The Concept of Law (3rd edn, Oxford University Press 2012)

HAWKING STEPHEN, A Brief History of Time (Bantam 1988)

HENCKAERTS JEAN-MARIE / DOSWALD-BECK LOUISE, Customary International Humanitarian Law-Volume 1: Rules (Cambridge University Press 2005)

HERDEGEN MATTIAS, 'Interpretation in International Law' in Rüdiger Wolfrum (ed), Max Planck Encyclopedia of Public International Law, online edition (Oxford University Press 2013)

HIGGINS ROSALYN

- Problems and Process: International Law and How We Use It (Oxford University Press 1994)

- 'Teaching and Practicing International Law in a Global Environment: Toward a Common Language of International Law' (2010) 104 American Society of International Law Proceedings 196-200

HORWITZ MORTON J, The Transformation of American Law 1870-1960: The Crisis of Legal Orthodoxy (Oxford University Press 1992)

HULL NATALIE E H, Roscoe Pound and Karl Llewellyn: Searching for an American Jurisprudence (University of Chicago Press 1977)

HYMES DELL

- 'On Communicative Competence' in John B Pride and Janet Holmes (eds), Sociolinguistics: Selected Readings (Penguin 1972) 53-73

- 'Speech and Language: On the Origins and Foundations of Inequality among Speakers’ (1973) 102 Dædalus 59-85 
IRWIN DOUGLAS A / WEILER JOSEPH H H, 'Measures Affecting the Cross-Border Supply of Gambling and Betting Services (DS 285)' (2008) 7 World Trade Review 71-113

JACOBSON ARTHUR J, 'The Idolatry of Rules: Writing Law According to Moses, with Reference to Other Jurisprudences' (1990) 11 Cardozo Law Review 1079-1132

JAKAB ANDRÁS, 'Kelsens Völkerrechtslehre zwischen Erkenntnistheorie und Politik' in Hauke Brunkhorst and Rüdiger Voigt (eds), Rechts-Staat: Staat, Internationale Gemeinschaft und Völkerrecht bei Hans Kelsen (Nomos 2008) 191-204

KAMMERHOFER JÖRG

- Uncertainty in International Law: A Kelsenian Perspective (Routledge 2011)

- 'Hans Kelsen in Today's International Legal Scholarship' in Jörg Kammerhofer and Jean d'Aspremont (eds), International Legal Positivism in a Post-Modern World (Cambridge University Press 2014) 81-113

KANT IMmanuel, Critique of Pure Reason (first published 1781, Cambridge University Press 1998)

\section{KELSEN HANS}

- Reine Rechtslehre: Einleitung in die rechtswissenschaftliche Problematik (Deuticke 1934)

- Legal Technique in International Law: A Textual Critique of the League Covenant (Geneva Research Centre 1939)

- Peace Through Law (University of North Carolina Press 1944)

- The Law of the United Nations: A Critical Analysis of Its Fundamental Problems (Stevens \& Sons 1951)

- 'Die Einheit von Völkerrecht und staatlichem Recht' (1958) 19 Zeitschrift für ausländisches öffentliches Recht und Völkerrecht 234-248

- Das Problem der Souveränität und die Theorie des Völkerrechts: Beitrag zu einer reinen Rechtslehre (first published 1920, Mohr Siebeck 1960)

- Principles of International Law (first published 1952, Holt, Rinehart and Winston 1967)

- 'Law and Logic' in Ota Weinberger (ed), Essays in Legal and Moral Philosophy (Reidel 1973) 228-253

- General Theory of Norms (first published 1979, Clarendon Press 1991)

- General Theory of Law \& State (first published 1949, Transaction 2006) 


\section{KENNEDY DAVID}

- 'Theses about International Law Discourse' (1980) 23 German Yearbook of International Law 354-391

- 'Spring Break' (1985) 63 Texas Law Review1377-1423

- 'The Turn to Interpretation' (1985) 58 Southern California Law Review 251-275

- 'Critical Theory, Structuralism and Contemporary Legal Scholarship' (1986) 21 New England Law Review 209-289

- International Legal Structures (Nomos 1987)

- 'A New Stream of International Law Scholarship' (1988) 7 Wisconsin International Law Journal 1-49

- 'Autumn Weekends: An Essay on Law and Everyday Life' in Austin Sarat and Thomas R Kearns (eds), Law in Everyday Life (University of Michigan Press 1995) 191-235

- 'When Renewal Repeats: Thinking Against the Box' (2000) 32 New York University Journal of International Law and Politics 335-500

- 'Challenging Expert Rule: The Politics of Global Governance' (2005) 27 Sydney Law Review 1-24

- 'Speaking Law to Power: International Law and Foreign Policy' (2005) 23 Wisconsin International Law Journal 173-181

- Of War and Law (Princeton University Press 2006)

- 'The Last Treatise: Project and Person (Reflections on Martti Koskenniemi's “From Apology to Utopia”)' (2006) 7 German Law Journal 982-992

- 'Assessing the Proposal for a Global Parliament: A Skeptics View' (2007) 13 Widener Law Review 395-399

- 'One, Two, Three, Many Legal Orders: Legal Pluralism and the Cosmopolitan Dream' (2007) 31 New York University Review of Law \& Social Change 641-659

- 'Law and Development Economics: Toward a New Alliance' in David Kennedy and Joseph E Stiglitz (eds), Law and Economics with Chinese Characteristics-Institutions for Promoting Development in the Twenty-First Century (Oxford University Press 2013) 19-70

- 'Law and the Political Economy of the World' (2013) 26 Leiden Journal of International Law 7-48

- A World of Struggle: How Power, Law, and Expertise Shape Global Political Economy (Princeton University Press 2016) 


\section{KENNEDY DUNCAN}

- 'Legal Formality' (1973) 2 The Journal of Legal Studies, 351-398

- ‘Form and Substance in Private Law Adjudication' (1976) 89 Harvard Law Review 1685-1778

- 'The Structure of Blackstone's Commentaries' (1979) 28 Buffalo Law Review 205-382

- 'A Left Phenomenological Critique of the Hart/Kelsen Theory of Legal Interpretation' (2007) 40 Kritische Justiz 296-305

KLABBERS JAN

- 'The Meaning of Rules' (2006) 20 International Relations 295-301

- 'Virtuous Interpretation' in Malgosia Fitzmaurice, Olufemi Elias, and Panos Merkouris (eds), Treaty Interpretation and the Vienna Convention on the Law of Treaties: 30 Years On (Martinus Nijhoff 2010) 17-37

KORHONEN OUTI, 'New International Law: Silence, Defence or Deliverance?' (1996) 7 European Journal of International Law 1-28

KOSKENNIEMI MARTTI

- 'The Politics of International Law' (1990) 1 European Journal of International Law 4-32

- 'The Police in the Temple: Order, Justice and the UN-A Dialectical View' (1995) 6 European Journal of International Law 325-348

- 'Hierarchy in International Law: A Sketch' (1997) 8 European Journal of International Law 566-582

- 'Letter to the Editors of the Symposium' (1999) 93 The American Journal of International Law 351-361

- 'Human Rights, Politics, and Love' (2001) 4 Mennesker \& Rettigheter 33-45

- 'International Law and Hegemony: A Reconfiguration' (2004) 17 Cambridge Review of International Affairs 197-218

- The Gentle Civilizer of Nations: The Rise and Fall of International Law 1870-1960 (Cambridge University Press 2004)

- 'Why History of International Law Today? (2004) 4 Rechtsgeschichte 61-66

- From Apology to Utopia: The Structure of International Legal Argument (first published 1989, Cambridge University Press 2005)

- 'Constitutionalism as Mindset: Reflections on Kantian Themes about International Law and Globalization' (2007) 8 Theoretical Inquiries in Law 9-36

- 'The Politics of International Law-20 Years Later' (2009) 20 European Journal of International Law 7-19 
- 'Law, Teleology and International Relations: An Essay in Counterdisciplinarity' (2011) 26 International Relations 3-34

- 'A History of International Law Histories' in Bardo Fassbender and Anne Peters (eds), The Oxford Handbook of the History of International Law (Oxford University Press 2012) 943-971

- 'Expanding Histories of International Law' (2016) 56 American Journal of Legal History 104-112

- and LEHTO, MARJA, 'The Privilege of Universality: International Law, Economic Ideology and Seabed Resources' (1996) 65 Nordic Journal of International Law 533-555

- and LEINO, PAÏVI, 'Fragmentation of International Law? Postmodern Anxieties' (2002) 15 Leiden Journal of International Law 553-579

KRÄMER SYBILLE, 'Sprache und Sprechen oder: Wie sinnvoll ist die Unterscheidung zwischen einem Schema und seinem Gebrauch?' in Sybille Krämer and Ekkehard König (eds), Gibtes eine Sprache hinter dem Sprechen? (Suhrkamp 2002) 97-125

KRESS KENNETH, 'Legal Indeterminacy’ (1989) 77 California Law Review283-337

KRISCH NICO, 'The Decay of Consent: International Law in an Age of Global Public Goods' (2014) 108 The American Journal of International Law 1-40

KUHN THOMAS S, The Structure of Scientific Revolutions ( $2^{\text {nd }}$ edn, University of Chicago Press 1970)

\section{LAKOFF GEORGE}

- Women, Fire, and Dangerous Things: What Categories Reveal about the Mind (University of Chicago Press 1990)

- and JOHNSEN MARK, Metaphors We Live By (University of Chicago Press 2003)

LANDAUER CARL, 'Book Review: International Legal Structures' (1989) 30 Harvard International Law Journal 287-304

LASSWELL HAROLD D / MCDOUGAL MYRES S, 'Legal Education and Public Policy: Professional Training in the Public Interest' (1943) 52 Yale Law Journal 203-295

\section{LAUTERPACHT HERSCH}

- Recognition in International Law (Cambridge University Press 1947)

- 'De l'interprétation des traités: Rapport' (1950) 43 Annuaire de l'Institut de Droit International 366-460 
- The Development of International Law by the International Court (Stevens \& Sons 1958)

- The Function of Law in the International Community (first published 1933, Oxford University Press 2011)

LEITER BRIAN

- 'Legal Indeterminacy' (1995) 1 Legal Theory 481-492

- NaturalizingJurisprudence: Essays on American Legal Realism and Naturalism in Legal Philosophy (Oxford University Press 2007)

LEPARD BRIAN D, Customary International Law: A New Theory with Practical Applications (Cambridge University Press 2010)

LINDERFALK ULF

- 'Good Faith and the Exercise of Treaty-Based Discretionary Powers' (2016)

- 'Why Should We Distinguish between the Exercise of Discretion and Interpretation?' (2019)

LLEWELLYN KARL N,

- 'Law and the Modern Mind: A Symposium' (1931) 31 Columbia Law Review 82-90

- 'Some Realism about Realism: Responding to Dean Pound' (1931) 44 Harvard Law Review1222-1264

- 'On Philosophy in American Law' (1934) 82 University of Pennsylvania Law Review and American Law Register 205-212

- 'Remarks on the Theory of Appellate Decision and the Rules and Canons about How Statutes are to be Construed' (1950) 3 Vanderbilt Law Review 395-406

- The Common Law Tradition: Deciding Appeals (Little, Brown \& Co 1960)

- 'A Lecture on Appellate Advocacy' (1962) 29 The University of Chicago Law Review 627-639

- Jurisprudence: Realism in Theory and Practice (Transaction 2008)

- The Theory of Rules (University of Chicago Press 2011)

- The Bramble Bush: On Our Law and Its Study (first published 1930, Quid Pro 2012)

LOWE VAUGHAN, 'Book Review: From Apology to Utopia: The Structure of International Legal Argument' (1990) 17 Journal of Law and Society 384-389

MCDOUGAL MYRES S

- 'Law as a Process of Decision: A Policy-Oriented Approach to Legal Study’ (1956) 1 Natural Law Forum 53-72 
- 'The Identification and Appraisal of Diverse Systems of Public Order' (1959) 53 The American Journal of International Law 1-29

- 'The International Law Commission's Draft Articles upon Interpretation: Textuality Redivivus' (1967) 61 The AmericanJournal of International Law 992-1000

MCDOUGAL MYRES S / FELICIANO FLORENTINO P, Law and Minimum World Public Order: The Legal Regulation of International Coercion (Yale University Press 1961)

MCDOUGAL MYRES S / LASSWELL HAROLD D / MILLER JAMES C, The Interpretation of Agreements and World Public Order: Principles of Content and Procedure (Yale University Press 1967)

MCDOUGAL MYRES S / LASSWELL HAROLD D / REISMAN W MICHAEL, 'Theories about International Law: Prologue to a Configurative Jurisprudence' (1968) 8 Virginia Journal of International Law 188-299

MCDOUGAL MYRES S / LASSWELL HAROLD D / CHEN LUNG-CHU, Human Rights and World Public Order: The Basic Policies of an International Law of Human Dignity (Yale University Press 1980)

MCDOUGAL MYRES S / REISMAN W MICHAEL, International Lawin Contemporary Perspective: The Public Order of the World Community-Cases and Materials (Foundation Press 1981)

MCDOUGAL MYRES S / BURKE WILLIAM T, The Public Order of the Oceans: A Contemporary International Law of the Sea (first published 1962, New Haven Press 1985)

MEHROTRA AJAY K, 'Law and the "Other”: Karl N. Llewellyn, Cultural Anthropology, and the Legacy of The Cheyenne Way’ (2001) 26 Law \& Social Inquiry $741-775$

MEY JACOB L, 'Zur kritischen Sprachtheorie' in Jacob L Mey (ed), Pragmalinguistics: Theory and Practice (De Gruyter 1979) 411-435

MILES CAMERON A, 'Indeterminacy' in Jean d'Aspremont and Sahib Singh (eds), Conceptsfor International Law: Contributionsto Disciplinary Thought (Edward Elgar 2019) 447-458

MÖLLERS CHRISTOPH, 'It's about Legal Practice, Stupid' (2006) 7 German Law Journal 1011-1014 
MONTESQUIEU (BARON DE) CHARLES DE SECONDAT, De l'esprit des lois, Book XI, De la constitution d'Angleterre (Barrillot, first published 1748)

MOORE MICHAEL S, ‘A Natural Law Theory of Interpretation' (1985) 58 Southern California Law Review 277-398

MOUFFE CHANTAL, On the Political (Routledge 2005)

NOLTE GEORG, 'Multipurpose Self-Defence, Proportionality Disoriented: A Response to David Kretzmer’ (2013) 24 European Journal of International Law 283-290

OLESEN JENS, 'Towards a Politics of Hermeneutics' in Andrea Bianchi, Daniel Peat, and Matthew Windsor (eds), Interpretation in International Law (Oxford University Press 2015) 311-330

OLIPHANT HERMAN / HEWITT ABRAHAM, 'Introduction' in Jacques Rueff, From the Physical to the Social Sciences (Johns Hopkins Press 1929) ix-xxxii

ORAKHELASHVILI ALEXANDER, The Interpretation of Acts and Rules (Oxford University Press 2008)

ORFORD ANNE, 'A Journal of the Voyage from Apology to Utopia' (2006) $7 \mathrm{Ger}$ man Law Journal 993-1010

PAUL JULIUS, The Legal Realism of Jerome N. Frank: A Study of Fact-Skepticism and the Judicial Process (Martinus Nijhoff 1959)

PAULUS ANDREAS L, Dieinternationale Gemeinschaft im Völkerrecht:EineUntersuchung zur Entwicklung des Völkerrechts im Zeitalter der Globalisierung (C H Beck 2001)

PEAT DANIEL / WINDSOR MATTHEW, 'Playing the Game of Interpretation: On Meaning and Metaphor in International Law' in Andrea Bianchi, Daniel Peat, and Matthew Windsor (eds), Interpretation in International Law (Oxford University Press 2015) 3-33

PELLER GARY, ‘The Metaphysics of American Law' (1985) 73 California Law Review 1151-1290

POLANYI MICHAEL, Personal Knowledge: Towards a Post-Critical Philosophy (Routledge 1958)

PRIULI VALERIO, Das Kosovo-Verfahren des internationalen Gerichtshofs: eine argumentationstheoretische Untersuchung (Duncker \& Humblot 2016) 
RAJAGOPAL BALAKRISHNAN, 'Martti Koskenniemi's From Apology to Utopia: A Reflection' (2006) 7 German Law Journal 1089-1094

RAWLS JOHN, A Theory of Justice (first published 1971, 1999 Harvard University Press)

\section{RAZ JOSEPH}

- The Authority of Law: Essays on Law and Morality (Oxford University Press 1979)

- The Morality of Freedom (Oxford University Press 1986)

REA-FRAUCHIGER MARIA A, Der amerikanische Rechtsrealismus: Karl N. Llewellyn, Jerome Frank, Underhill Moore (Duncker \& Humblot 2006)

ROSENFELD MICHEL

- 'Deconstruction and Legal Interpretation: Conflict, Indeterminacy and the Temptations of the New Legal Formalism' in Drucilla Cornell, Michel Rosenfeld, and David G Carlson (eds), Deconstruction and the Possibility ofJustice (Routledge 1992) 152-210

- Just Interpretations: Law between Ethics and Politics (University of California Press 1998)

RUB ALFRED, Hans Kelsens Völkerrechtslehre: Versuch einer Würdigung(Schulthess 1995)

RUFFERT MATTHIAS / WALTER CHRISTIAN, Institutionalisiertes Völkerrecht (C H Beck 2009)

RUGGIE JOHN, 'International Responses to Technology: Concepts and Trends' (1975) 29 International Organization 557-583

SACKS HARVEY, 'On the Analysability of Stories by Children' in Roy Turner (ed), Ethnomethodology (Penguin Education 1974) 216-232

SAUSSURE FERDINAND DE, Course in General Linguistics (first published 1916, Philosophical Library 1965)

SCALIA ANTONIN, 'Common-Law Courts in a Civil-Law System: The Role of the United States Federal Courts in Interpreting the Constitution and Laws' in Amy Gutmann (ed), A Matter of Interpretation: Federal Courts and the Law (Princeton University Press 1997) 3-47

SCHACHTER OSCAR, 'The Invisible College of International Lawyers' (1977) 72 Northwestern University Law Review 217-226 
SCHAUER FREDERICK

- 'Formalism' (1988) 97 Yale Law Journal 509-548

- Playing by the Rules: A Philosophical Examination of Rule-Based DecisionMaking in Law and in Life (Clarendon Law Series 1993)

SCHILL STEPHAN W, 'General Principles of Law and International Investment Law' in Eric De Brabandere and Tarcisio Gazzini, International Investment Law: Sources of Rights and Obligations (Martinus Nijhoff 2012) 133-181

SCHWÖBEL CHRISTINE, 'The Comfort of International Criminal Law' (2013) 24 Law and Critique 169-191

SCOBBIE IAIN, 'Towards the Elimination of International Law: Some Radical Scepticism about Sceptical Radicalism' (1990) 61 British Yearbook of International Law 339-362

SEARLE JOHN R

- Speech Acts: An Essayin the PhilosophyofLanguage (Cambridge University Press 1969)

- Making the Social World (Oxford University Press 2010)

SEIDL-HOHENVELDERN IGNAZ / LOIBL GERHARD, Das Recht der Internationalen Organisationen einschließlich der supranationalen Gemeinschaften (7thedn, Carl Heymanns 2000)

SHAFFER GREGORY / GINSBURG TOM, 'The Empirical Turn in International Legal Scholarship' (2012) 106 The American Journal of International Law 1-46

SHERRY SUZANNA, 'Putting the Law Back in Constitutional Law' (2009) 25 Constitutional Commentary 461-465

SINGER JOSEPH W, ‘The Player and the Cards: Nihilism and Legal Theory’ (1984) 94 Yale Law Journal 1-70

SINGH SAHIB, 'Koskenniemi's Images of the International Lawyer' (2016) 29 Leiden Journal of International Law 699-726

SOFAER ABRAHAM D, 'On the Necessity of Pre-emption' (2003) 14 European Journal of International Law 209-226

SOLUM LAWRENCE B, 'On the Indeterminacy Crisis: Critiquing Critical Dogma' (1987) 54 The University of Chicago Law Review 462-503

SOREL JEAN-MARC / BORÉ-EVENO VALÉRIE, 'Article 31' in Olivier Corten and Pierre Klein (eds), The Vienna Conventions on the Law of Treaties: A Commentary (Oxford University Press 2011) 804-837 
STOLJAR NATALIE, 'Survey Article: Interpretation, Indeterminacy and Authority: Some Recent Controversies in the Philosophy of Law' (2003) 11 The Journal of Political Philosophy 470-498

TEITEL RUTI / HOWSE ROBERT, 'Cross-Judging: Tribunalization in a Fragmented but Interconnected Global Order' (2009) 41 New York University Journal of International Law \& Politics 959-990

THIRLWAY HUGH, The Sources of International Law (2nd edn, Oxford University Press 2019)

TRIMBLE PHILLIP R, 'Review Essay: International Law, World Order, and Critical Legal Studies' (1990) 42 Stanford Law Review 811-845

UNGER ROBERTO M, Knowledge and Politics (Free Press 1975)

VAGTS DETLEV F, 'Treaty Interpretation and the New American Ways of Law Reading' (1993) 4 European Journal of International Law 472-505

VAN DAMME ISABELLE, Treaty Interpretation by the WTO Appellate Body (Oxford University Press 2009)

VENZKE INGO

- How Interpretation Makes International Law (Oxford University Press 2012)

- 'What Makes for a Valid Legal Argument' (2014) 27 Leiden Journal of International Law 811-816

- 'International Law and its Methodology: Introducing a New Leiden Journal of International Law Series' (2015) 28 Leiden Journal of International Law 185-187

- 'Is Interpretation in International Law a Game?' in Andrea Bianchi, Daniel Peat, and Matthew Windsor (eds), Interpretation in International Law (Oxford University Press 2015) 352-370

- 'Sources in Interpretation Theories: The International Law-Making Process' in Samantha Besson and Jean d'Aspremont (eds), The Oxford Handbook of the Sources of International Law (Oxford University Press 2017) 401-421

- 'Semantic Authority, Legal Change and the Dynamics of International Law' in Patrick Capps and Henrik Palmer Olsen (eds), Legal Authority beyond the State (Cambridge University Press 2018) 102-126

WAIBEL MICHAEL, 'Interpretive Communities in International Law' in Andrea Bianchi, Daniel Peat, and Matthew Windsor (eds), Interpretation in International Law (Oxford University Press 2015) 147-165 
WALDRON JEREMY, 'Vagueness and the Guidance of Action' in Andrei Marmor and Scott Soames (eds), Philosophical Foundations of Language in the Law (Oxford University Press 2011) 58-82

WINTER STEVEN L, A Clearing in the Forest: Law, Life, and Mind (University of Chicago Press 2001)

WITTGENSTEIN LUDWIG

- Philosophical Investigations (Blackwell 1958)

- On Certainty (Blackwell 1969)

YABLON CHARLES M, 'Forms' in Drucilla Cornell, Michel Rosenfeld, and David Gray Carlson (eds), Deconstruction and the Possibility ofJustice (Routledge 1992) 258-262

ZAREMBY JUSTIN, Legal Realism and American Law (Bloomsbury 2014)

ZEMACH ARIEL, 'Indeterminacy in the Law of War: The Need for an International Advisory Regime' (2017) 43 Brooklyn Journal of International Law 1-74

ZURN CHRISTOPHER F, Deliberative Democracyand the Institutions ofJudicial Review (Cambridge University Press 2009) 

About the author:

Severin Meier holds a BA in International Relations from the University of Geneva, an LL.M. in Public International Law from the University of Leiden and a Magister Juris from the University of Oxford. He completed his doctoral studies at the University of Zurich, worked for the Swiss Foreign Ministry and is currently a political and legal advisor at the Swiss parliament.

The Faculty of Law of the University of Zurich accepted this thesis as a doctoral dissertation on 30 September 2020 at the request of Prof. Dr. Oliver Diggelmann and Prof. Dr. Bardo Fassbender and awarded it the distinction summacum laude. 
sui generis is an association dedicated to the promotion of free access to legal literature, court decisions, decisions of authorities and legislative materials. Since 2014, a legal open access journal has been published under the label sui generis. In 2019, the sui generis publishing house was founded.

suigeneris book series

edited by Daniel Hürlimann and Marc Thommen

In this series, legal dissertations and postdoctoral theses, as well as textbooks and specialized publications, are made available to a wide audience. The books in this series are published in printed and online versions. The digital version is freely accessible worldwide (open access). The copyright remains with the authors; the works are published under a Creative Commons licence.

Published so far in the sui generis series:

001 - Monika Simmler: Normstabilisierung und Schuldvorwurf

002 - Marc Thommen: Introduction to Swiss Law

003 - Silvio Hänsenberger: Die zivilrechtliche Haftung für autonome Drohnen unter Einbezug von Zulassungs- und Betriebsvorschriften

004 - Mais A.M. Qandeel: Enforcing Human Rights of Palestinians in the Occupied Territory

005 - Moritz Oehen: Der Strafkläger im Strafbefehls- und im abgekürzten Verfahren

006 - Jens Lehne: Crisis at the WTO: Is the Blocking of Appointments to the WTO Appellate Body by the United States Legally Justified?

007 - Lorenz Garland: Waffengleich heit im Vorverfahren

008 - Christoph Urwyler: Die Praxis der bedingten Entlassung aus dem Strafvollzug

009 - Dominik Elser: Die privatisierte Erfüllung staatlicher Aufgaben

010 - David Henseler: Datenschutz bei drohnengestützter Datenbearbeitung durch Private

011 - Lorenz Raess: Court Assistance in the Taking of Evidence in International Arbitration

012 - Christoph Hurni/Christian Josi / Lorenz Sieber: Das Verfahren vor dem Berner Kindes- und Erwachsenenschutzgericht

013 - Emanuel Bittel: Die Rechnungsstellung im schweizerischen Obligationenrecht

014 - Stephan Bernard: Was ist Strafverteidigung?

015 - Frédéric Erard: Le secret médical 
016 - Valentin Botteron: Le contrôle des concentrations d'entreprises

017 - Monika Pfyffer von Altishofen: Ablehnungs- und Umsetzungsraten von Organtransplantationen

018 - Kristin Hoffmann: Kooperative Raumplanung: Handlungsformen und Verfahren

019 - APARIUZ XXII: Unter Gleichen

020 - Raphaël Marlétaz: L’harmonisation des lois cantonales d'aide sociale

021 - Roger Plattner: Digitales Verwaltungshandeln

022 - Nicole Roth: Miteigentum an Grundstüicken und einfache Gesellschaft

023 - Reto Pfeiffer: Vertragliche Rechtsfolge der «Verwendung missbräuchlicher Geschäftsbedingungen»

024 - Marina Piolino: Die Staatsunabhängigkeit der Medien

025 - Severin Meier: Indeterminacy of International Law? 
Published in the sui generis series, edited by Daniel Hürlimann and Marc Thommen.

$1^{\text {st }}$ edition, 30 November 2021

(c) 2021 Severin Meier

Print of the dissertation approved by the Faculty of Law of the University of Zurich.

This work has been published under a Creative Commons license which requires only the attribution of the author when being reused (CC BY 4.0 - https://creativecommons.org/licenses/by/4.0).

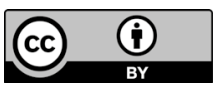

Published with the support of the Swiss National Science Foundation.

ISBN: 978-3-907297-25-4

DOI: $10.38107 / 025$

Proofreading: Sandra Ujpétery

Design: Müller+Hess, Basel

Print: Ebner \& Spiegel, Ulm 


\section{5}
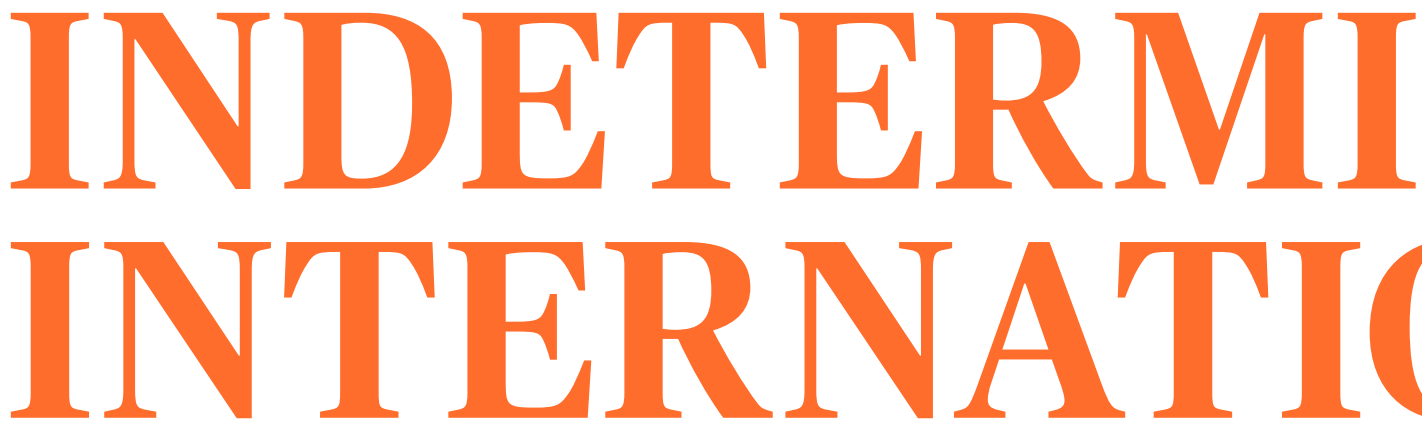

The most important (in)determinacy theses in international law since the 1920s are scrutinised in this book. As Severin Meier demonstrates, the extent of legal determinacy depends neither on some linguistic essence found in the text nor on theories that allegedly stand above practice. Instead, the (in)determinacy of law is shown to arise purely from practice. This reconceptualisation of a key discussion in legal philosophy provides a new perspective on the frame of meaning of legal norms. 